Contribuições para a conservação de Bradypus variegatus (preguiça comum)

Processos históricos e demográficos moldando a diversidade nuclear

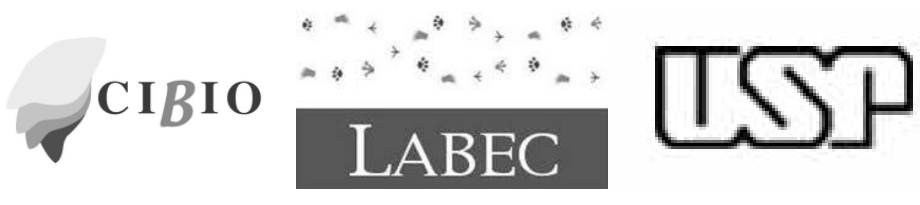

São Paulo 
Contribuições para a conservação de Bradypus variegatus (preguiça comum)

Processos históricos e demográficos moldando a diversidade

\author{
nuclear \\ (Versão Corrigida)
}

(Versão Original disponível no Instituto de Biociências da Universidade de São Paulo)

Tese apresentada ao Instituto de Biociências da Universidade de São Paulo, para a obtenção do título de Doutor em Biologia, na área de Genética.

Orientação: Dra. Nadia de Moraes-Barros

Prof. Dr. João Stenghel Morgante

Prof. Dr. Nuno Ferrand

São Paulo 
Silva, Sofia Marques

Contribuições para a conservação de Bradypus variegatus (preguiça comum): Processos históricos e demográficos moldando a diversidade nuclear

$180 \mathrm{pp}$.

Tese de Doutorado - Instituto de Biociências da Universidade de São Paulo. Departamento de Genética e Biologia Evolutiva.

1. Genética de populações 2. Mata Atlântica Brasileira 3. Bradypus I. Universidade de São Paulo. Instituto de Biociências. Departamento de Genética e Biologia Evolutiva.

Comissão Julgadora:

Prof(a). Dr(a).

Prof(a). Dr(a).

Prof(a). Dr(a).

Prof(a). Dr(a).

Prof(a). Dr(a).

Orientador(a) 
Ao Prof. João Stenghel Morgante 


\section{AGRADECIMENTOS}

Em alguns dos próximos capítulos, vários nomes são citados pela sua contribuição neste trabalho. A lista de colaborações é extensa, mas peço desculpa pois talvez não seja tão exaustiva como deveria, e reconheço que alguns nomes devem ter ficado em falta por puro esquecimento. Obrigada Sr. Sebastião Silva da Resex Chico Mendes (Acre), Sr. Renato (AMOPREX, Xapuri), Sr. Silva (AMOPREB, Brasiléia), Sra. Odinéia (AMOPREAB, Assis Brasil) e tantos outros moradores que fazem com que o Acre de fato exista e seja hospitaleiro e prestativo, Guilherme Andreoli e demais equipe do projeto Fauna Viva e staff do PARNASO, Sérgio Leal de Alagoas, alunos da Prof. ${ }^{a}$ Flávia Barros da UFAL. Agradeço muito a todas as pessoas que individualmente ou em nome de uma instituição colaboraram neste trabalho.

O avanço científico faz-se através da colaboração, confiança e principalmente partilha, seja de dados, amostras ou simplesmente conhecimento. Os co-autores dos próximos capítulos foram um exemplo disso mesmo e por isso estou-lhes muito grata.

A Fundação para a Ciência e Tecnologia (FCT), a Fundação de Amparo à Pesquisa do Estado de São Paulo (FAPESP), a Coordenação de Aperfeiçoamento de Pessoal de Nível Superior (CAPES) e a própria USP merecem igualmente um reconhecimento específico, pela contribuição financeira que deram a este trabalho.O apoio "logístico" das secretarias do IB foi ótimo; agradeço particularmente a ajuda de Deisy Santos de Morais, Helder Souza e Shirlene Fernandes.

Agradeço o acolhimento, preocupação, palavras de incentivo e partilha de conhecimento do Prof. João Morgante; o entusiasmo do Prof. Ferrand no desenvolvimento do projeto das preguiças e a possibilidade de fazer este doutoramento; a presença incansável, motivação, paciência, discussões da Nadia de Moraes-Barros. Uma vez recebi um email dizendo que eu deveria ser especial, já que tinha tantos orientadores. Não sei o que a pessoa quis dizer com isso, mas agradeço-vos terem-me feito sentir de fa(c)to especial.

Em Portugal vários colegas e amigos contribuíram direta e/ou indiretamente para que eu conseguisse realizar este trabalho tal como aqui se apresenta. Mais uma vez esta lista pecará pela ausência de nomes importantes e será curta nas descrições. Desculpem-me! Joana Abrantes espero que os teus abracinhos, amizade e orientações nunca me faltem; Sandra Afonso mantém a tua loucura e a tua maturidade, as doses estão equilibradíssimas; Helena Areal aprendi contigo que as aventuras se fazem passo a passo e que os passos se vão desenhando na nossa cabeça antes de serem dados; Diana Castro podes ter a certeza que ainda nos mantemos na mesma montanha russa; Ana Matos partilhamos distâncias, compreendemos que não se encurtam quando deveriam, mas que às vezes se tornam muito pequeninas; Fabiana Neves obrigada pelo sorriso/animação dos últimos dias; Rita Oliveira vivi no estrangeiro como me mandaste, obrigada pelo melhor dos conselhos e pelo exemplo; Teresa Silva obrigada pelo companheirismo e preocupação incansável que te mói, mas que podemos confiar, e por todas as 
leituras atentas e discussões; Sofia Mourão mais que uma colega, uma amiga. A todos os colegas e amigos que tornaram o trabalho de laboratório uma verdadeira aventura, preenchidíssima, obrigada, valeu, gracias, thank you, ačiū (Jolita, I hope Google has translated this right!)... «Com irritação: “Trabalho é trabalho, outra coisa é outra coisa!”. Pausadamente: “Conhaque, a outra coisa é conhaque.”» - só pude rir às gargalhadas! Obrigada também àqueles que fora do lab. contribuíram para a manutenção da minha sanidade mental a cada regresso a casa. Sílvia Araújo onde vamos conversar na próxima sexta? Qual é o evento para o próximo sábado?

A vida académica leva-nos muitas vezes a confundir a vida profissional com a vida pessoal. Este trabalho é uma prova disso mesmo. Mais do que crescimento profissional e aprendizagem sobre genética, biologia, evolução, preguiças... aprendi a conhecer-me melhor, a ser melhor e cresci. Cresci tanto. O ditado popular diz que "amigo do meu amigo, meu amigo é". E os muitos amigos que fiz em São Paulo trouxeram outros consigo, e são tantos os nomes dos meus novos amigos que merecem uma palavra por escrito que, mais uma vez, sou obrigada a desculpar-me se seu nome não está aqui. Agradeço-vos Nadia de Moraes-Barros e Gustavo, a vossa hospitalidade, paciência, conversas, conselhos, a mão no ombro quando precisei... Obrigada Camila Clozato, Rodrigo Francisco e Maria Helena Maia - meus pilares brasileiros, meus conselheiros, meus psicólogos, amigos para todas as ocasiões; Obrigada família brasileira, Ana Carolina Pavan e Natilinha Guimarães, trabalhamos juntas, mudamo-nos juntas, brindamos juntas, viajamos juntas, divertimo-nos tanto, não moramos na mesma casa - vivemos juntas; obrigada ainda às vossas famílias pelo carinho; Juliana Machado Ferreira e Gisele Dantas obrigada também às vossas famílias pela hospitalidade e preocupação; Ju obrigada pelos momentos bons e aprendizado que partilhamos; Gi obrigada pelo exemplo de coragem e determinação; Márcia Pinceratti, a responsável pela primeira balada paulista; obrigada pelo positivismo, entusiasmo e sorriso contagiantes; Felipe Martins, obrigada pela irreverência e partilha de conhecimentos; Helena Tadiello, Ana Carol Millo e principalmente Gabriella Cardoso, tem sido fantástico ver-vos atingir os vossos objetivos; Bárbara Bitarello, obrigada pela confiança; Kelly Nunes obrigada por toda a ajuda e pelo primeiro chocolate quente de São Paulo; Adriana Ballesteros lembras-te de te perguntarem como sabias tanto sobre genética de populações não sendo essa a tua área? A resposta simples "estudei" conquistou-me. Isso e os brincos fatia de melancia. Obrigada pelo empenho no estudo, no divertimento, no descanso, obrigada pela comitiva colombiana... Helena Bernardes, obrigada pela confiança e pela amizade. Yara Marassato, obrigada por me mostrares o Brasil pelos teus olhos, por me acolheres como parte da família, pelo samba, pelo Rio, pela Casa do Norte, pelas coisas simples do dia-a-dia... A todos os colegas e amigos que me acompanharam em São Paulo/Brasil, obrigada pela integração: "Sófis, como você não lembra? Passou durante anos na TV, de segunda a sexta...?!" "Pois, mas eu não vivia aqui...” “Ah é!”. 
... Faltam tantos nomes...

Durante este percurso a minha família em Portugal mudou muito. Mas há pessoas que serão sempre garantidas. Obrigada Pai, obrigada Mãe, obrigada Irmã. 
ÍNDICE

Resumo

pág. VIII

Abstract

pág. IX

Capítulo 1. Introdução Geral

pág. 1

Capítulo 2. Divide to conquer: a complex pattern of biodiversity depicted by vertebrate components in the Brazilian Atlantic forest

pág. 16

Capitulo 3. Study of populations as biodiversity components: the common and the endangered Bradypus sloths

pág. 41

Capitulo 4. Bradypus variegatus' (common sloth) demography as a model to study the Brazilian Atlantic forest past bridges, paths and processes pág. 70

Capítulo 5. The consequences of using the most polymorphic microsatellites on wildmammals' genetic diversity estimates. pág. 95

Capitulo 6. Towards a standard framework to describe behaviors in the common sloth (Bradypus variegatus): novel interactions data observed in distinct fragments of the Atlantic forest, Brazil pág. 116

Capítulo 7. Contribution of governmental centers for wildlife to study the biology of sloths (Bradypus variegatus) in Brazilian anthropogenic habitats pág. 125

Capítulo 8. Discussão Geral e Conclusões pág. 137 


\section{RESUMO}

Este trabalho encontra-se focado nas populações de preguiça comum da Mata Atlântica brasileira, em seus níveis de diversidade genética e sua estruturação populacional. $O$ refinamento dos padrões de diversidade genética destas populações, e a procura dos processos que estariam na sua origem, levaram a que neste trabalho se incluíssem contribuições para o conhecimento do habitat e da espécie. Para tal, utilizaram-se ferramentas de genética, biogeografia, etologia e ecologia, numa perspetiva integrativa e comparativa.

Inicialmente, a simplicidade da distribuição da biodiversidade da Mata Atlântica foi contrariada, propondo-se nove componentes bióticos de vertebrados terrestres, estritamente florestais. Além disso, essa heterogeneidade foi encontrada a nível local e regional. Na sua base, estariam inúmeros e distintos processos climáticos, orográficos e biológicos, atuando de diferente modo em cada componente. $\mathrm{O}$ estudo genético das populações de preguiça comum da Mata Atlântica corroborou que estes processos gerais influenciaram também esta espécie, e que o estudo de fina-escala contribui para uma melhor definição dos processos históricos e demográficos que influem seus padrões de diversidade genética. Pela primeira vez foram inferidas a formação e a manutenção de sistemas de metapopulações na Mata Atlântica, através da análise dos padrões de diversidade genética e da demografica da preguiça comum.

Também pela primeira vez se realizou o estudo genético da preguiça anã, espécie criticamente ameaçada. Tal como esperado, sua única população apresentou baixos níveis de diversidade genética, com sinais de gargalo demográfico, embora sem sinais de endogamia.

Finalmente, apesar da preguiça comum ser considerada não-ameaçada, este trabalho identifica a necessidade de medidas de conservação a nível populacional para a espécie. As populações Atlânticas carecem de medidas de conservação devido à sua diferenciação e isolamento em relação às populações Amazônicas, com presença de alelos únicos na Mata Atlântica; à estruturação populacional no bioma, com indícios de baixo fluxo gênico e elevados índices de endogamia em cada uma das populações; aos baixos níveis de diversidade genética encontrados nas populações da Mata Atlântica (particularmente a diversidade genética da população do sul é menor do que a registrada em populações ameaçadas de preguiça de coleira e de preguiça anã); às evidências de requerimentos biológicos distintos dessas populações, pela perceção de épocas reprodutivas diferentes; e à forte influência antrópica, quer pelo impacto direto do desmatamento e aumento do contato com regiões urbanas.

A redefinição das unidades de manejo anteriormente descritas, a proposta de utilização da preguiça comum como espécie bandeira em ações para a sua conservação, da Mata Atlântica e de outras espécies de preguiça e o forte incentivo à realização de mais estudos genéticos (com aumento de amostragem) e ecológicos constituem as medidas de conservação sugeridas para o futuro da preguiça comum na Mata Atlântica. 


\section{ABSTRACT}

This work is focused on the Atlantic forest common sloth populations, their genetic diversity levels and structure. The refinement of these populations' genetic diversity patterns and the investigation of the processes on their origin were the main goals. Thus contributions to the knowledge of the habitat and the species are included. Genetic, but also biogeographic, ecologic and ethologic tools were used, in an integrative and comparative perspective.

Initially, the simplicity of the distribution of diversity patterns within the Atlantic forest was refuted by proposing nine biotic components of terrestrial forest-dependent vertebrates. Heterogeneity at local and regional level was found, and reported to be influenced by many different processes, climatic, orographic and biological, acting differently in each component. The genetic study of the Atlantic forest common sloth populations corroborated that these general processes have also influenced this species, and that the fine-scale study contributes to a better definition of the historical and demographic processes influencing it. The formation and maintenance of metapopulation systems within the Atlantic forest were inferred for the first time. The analyses of the common sloth patterns of genetic diversity and its historical demography contributed to this conclusion.

This is also the first study on the genetic diversity of the pygmy sloth, a critically endangered species. As expected, its single population has low levels of genetic diversity and signs of bottleneck, although it seems not to be an inbred population.

Finally, despite the common sloth being considered a least concerned species, this work identifies the need for conservation at the species' population level. Atlantic forest populations require management measures due to: their differentiation and isolation from the Amazonian populations, with private alleles within Atlantic forest; the population structure within the biome, with evidences of low gene flow and high levels of inbreeding within each population; the low levels of genetic diversity found within these management units (particularly the genetic diversity of the southern population is inferior to that recorded in populations of the endangered maned sloth and pygmy sloth); the evidence of these populations' distinct biological requirements, by the perception of different reproductive seasons; and the strong anthropogenic influence, either by the direct impact of deforestation, and the increased contact with urban areas.

The redefinition of previously described management units, the proposal of the common sloth as a flagship species in conservation actions for the species itself, the Atlantic forest's and other sloth species', and the recommonedation to increase genetic (with increased sampling) and ecological studies constitute the conservation measures suggested for the future of the common sloth populations within the Atlantic forest. 


\section{CAPÍTUlo 1. Introdução Geral}

\section{Diversificação dos biomas florestais Brasileiros}

O Brasil é marcado pela existência de três principais conjuntos de biomas: as florestas (Amazônia a oeste e Mata Atlântica a leste), divididas por formações vegetais tipo-savana (Cerrado, Caatinga e Pantanal), e um terceiro bioma de vegetação campestre que delimita a sul a Mata Atlântica (Campos Sulinos; IBGE 2011). No passado, a ligação entre as florestas teria sido possibilitada, quer pela sua expansão quando em condições climáticas favoráveis, quer pela conexão fomentada por Matas de Galeria que atravessariam o território brasileiro (De Oliveira et al. 1999; Behling 2002; Auler et al. 2004a, b; Pessenda et al. 2004; Wang et al. 2004). Diversos estudos de vertebrados reúnem evidências da ligação entre as formações vegetais mencionadas (Costa 2003; Fernandes et al. 2004; Carnaval \& Bates 2007; Tchaicka et al. 2007; Cabanne et al. 2008; Martins et al. 2009; Vilaça \& Santos 2010). Por outro lado, as propostas e explicações dos processos de diversificação da Amazônia foram aplicadas no estudo da Mata Atlântica (Carnaval \& Moritz, 2008; Puorto et al. 2001). Apesar de hoje em dia as florestas brasileiras se encontrarem isoladas (IBGE 2011), o estudo e entendimento dos processos de diversificação da Amazônia estão, direta e indiretamente, relacionados com a origem da diversidade Atlântica. Assim, nos próximos parágrafos é feita uma rápida abordagem aos processos de diversificação de vertebrados na Amazônia e posteriormente é resumido o conhecimento sobre a Mata Atlântica.

A floresta Amazônica é um dos biomas mais emblemáticos do planeta Terra. Apelidada de "pulmão do mundo" na década de 90, é a região que mais atenção tem tido por parte da comunidade internacional, quer seja ela científica, política ou social. Deste modo, a biodiversidade da floresta Amazônica desde há muito intriga os cientistas e diversos processos têm sido propostos e debatidos para a explicar.

Uma das primeiras explicações foi denominada como teoria dos refúgios pleistocênicos. Segundo Haffer (1969), fragmentos de floresta teriam sido mantidos em regiões com maior pluviosidade, capazes de suportar vegetação florestal durante os períodos de seca do Pleistoceno e onde, portanto, teria sido possível manter um maior número de espécies. Durante esses períodos, os refúgios estariam isolados uns dos outros, o que por vicariância levaria à diferenciação das populações de cada um deles e mesmo à sua especiação (Haffer 1969). Mas em alguns casos, os padrões genéticos e filogeográficos seriam mais parcimoniosamente explicados por eventos de dispersão e não por vicariância (Steiner \& Catzeflis 2004). Noutros, não foi possível detectar o sinal de expansão populacional que seria previsto pela teoria dos refúgios, pois após o Pleistoceno e com a melhoria das condições climáticas, as populações isoladas tenderiam a expandir-se para fora dos refúgios (Lessa et al. 2003). Ainda em outros 
casos, a diferenciação encontrada entre linhagens distintas seria anterior ao Pleistoceno e, portanto, não seria explicada pela formação dos refúgios nessa época (Silva \& Patton, 1998).

Consequentemente, outros fenômenos foram sendo equacionados para explicar os padrões de distribuição de mamíferos terrestres. Mantendo a possibilidade de diferenciação por vicariância, Ayres \& Clutton-Brock (1995) foram dos primeiros autores a evidenciar o papel preponderante dos rios da bacia Amazônica como barreiras à dispersão. Por outro lado, Silva \& Patton (1998) relacionaram a localização e idade de barreiras geológicas, nomeadamente o Arco de Iquitos, com a distribuição da diversidade genética de algumas espécies. Especiação parapátrica foi também proposta como alternativa à teoria dos refúgios. Segundo Endler (1977), novas espécies poderiam surgir devido a gradientes ecológicos que forçariam à diferenciação de populações ocorrendo em ambientes distintos. Entretanto, teorias mais complexas e mais dificilmente testadas apontavam ainda para a influência das alterações palaeogeográficas (Marroig \& Cerqueira 1997) e palaeoclimáticas (Bush 1994; Colinvaux et al. 1996) como principais agentes diversificadores.

Recentemente foi proposta uma teoria abrangente e integrativa dos diversos processos citados, indicando-os como atores e geradores da diversidade da Amazônia. Deixou de se ter uma visão isolada desses fenômenos, passando a vê-los de um modo inclusivo (Hoorn et al. 2010). Segundo a revisão de Hoorn et al. (2010), a região Amazônica teria maior extensão do que atualmente, mas com a movimentação tectónica, várias mudanças foram ocorrendo, entre elas: o retraimento de incursões marinhas no noroeste da região; a formação do sistema hidrográfico Pebas, localizado na região sub-andina; a formação contínua mas faseada dos Andes de sul para norte; a formação do sistema hidrográfico Acreano e drenagem do Amazonas para o Atlântico; a expansão da floresta tropical de terra firme e o encerramento do Istmo do Panamá ligando as Américas e permitindo o Grande Intercâmbio Biótico nas Américas (Webb 2006).

Contrariamente, o entendimento da origem da diversidade da Mata Atlântica é ainda menos desenvolvido. À semelhança do que foi inicialmente proposto para a Amazônia, também a Mata Atlântica era considerada como uma floresta homogênea (Cracraft 1985). No entanto, a definição oficial atual de Mata Atlântica inclui diferentes tipos de floresta (ombrófila densa, ombrófila mista, ombrófila aberta, estacional semidecidual e estacional decidual) e ecossistemas (restingas, manguezais e brejos de altitude; IBGE 2011).

A importância do estudo da Mata Atlântica prende-se não só com a ausência do conhecimento aprofundado sobre o territótio, mas também com o fato de este bioma enfrentar atualmente, e desde os Descobrimentos, uma excessiva exploração, degradação e perda de habitat devido a intensa atividade humana (Conservation International do Brasil et al. 2000; Fundação SOS Mata Atlântica \& INPE 2011). O reconhecimento da importância biológica da Mata Atlântica está patente na definição de Reservas Mundiais da Biosfera por parte da 
UNESCO (United Nations Educational, Scientific and Cultural Organization; CNRBMA 2009). Em 2000, Myers et al. evidenciaram-na também como o bioma mais ameaçado da América do Sul, contabilizando a perda de mais de $90 \%$ de sua extensão histórica, mas com a manutenção de um elevado grau de endemismo e riqueza específica. Mais recentemente, Ceballos \& Ehrlich $(2006,2009)$ corroboraram estas evidências, demonstrando que a Mata Atlântica suporta uma das mais ricas e únicas faunas de mamíferos do Mundo.

Igualmente, com o avanço do estudo científico da Mata Atlântica, foram sendo detetados padrões de distribuição da sua diversidade e a heterogeneidade do bioma foi começando a ser ressaltada (Costa 2003). Tal como acima mencionado, hipóteses anteriormente utilizadas para explicar a diversificação na Amazônia foram sendo enunciadas e testadas na Mata Atlântica. Por exemplo, Puorto et al. (2001) reuniram evidências de que alguns rios poderiam funcionar como barreiras à dispersão, as alterações climáticas durante o Quaternário foram apontadas, entre outros, por Moraes-Barros et al. (2010) e a hipótese dos refúgios foi testada por Carnaval \& Moritz (2008).

Ao longo do tempo surgiram também propostas específicas para o estudo do bioma, nomeadamente a hipótese do isolamento nas montanhas (Lara et al. 2005). Segundo os autores são inúmeros os pequenos mamíferos que parecem ter ficado isolados, e por isso especiado, após o soerguimento das Serras do Espinhaço, do Mar, da Mantiqueira e dos Órgãos. No entanto, a antiguidade da formação destas cadeias e a presença destes roedores dependentes de floresta contrasta com os recentes eventos de expansão populacional de outros mamíferos (Martins et al. 2007, 2009; Miranda et al. 2007), levantando a questão de quando teria o clima permitido o aparecimento e manutenção de floresta nesta região.

Assim que foram aumentando os estudos de distintos mamíferos, amplamente distribuídos pela região neotropical, voadores (Ditchfield 2000; Martins et al. 2007), não-voadores (Costa 2003), estritamente florestais (Moraes-Barros et al. 2006) ou generalistas (Tchaicka et al. 2007; Martins et al. 2009), começou-se a perceber a existência de um padrão de distribuição em que cada táxon se dividia em dois grupos distintos, um mais a norte e outro mais a sul na Mata Atlântica. Por exemplo, a preguiça comum (Bradypus variegatus) dividia-se em um haplogrupo do norte presente na Bahia e em Minas Gerais e outro do sul detectado em São Paulo (MoraesBarros et al. 2006). Enquanto para a preguiça de coleira (B. torquatus), o haplogrupo do norte também correspondia à região da Bahia, o do sul localizava-se na região de Espírito Santo e Rio de Janeiro (Lara-Ruiz et al. 2008). Apesar das diferenças na localização dos haplogrupos norte e sul em cada táxon, estabeleceu-se a hipótese dos dois-componentes para definir especificamente a distribuição da biodiversidade ao longo de toda a Mata Atlântica. Esta hipótese, referida pela primeira vez por Costa et al. (2000) nunca foi explicitamente formalizada. Deste modo, os processos responsáveis pelos padrões de biodiversidade Atlânticos continuaram pouco definidos e um tanto abstratos. 


\section{Espécies de preguiça de três dedos (gênero Bradypus)}

As preguiças de três dedos pertencem ao gênero Bradypus. Nele se incluem, a preguiça do norte ou preguiça de garganta amarela (B. tridactylus), a preguiça anã (B. pygmaeus), a preguiça de coleira (B. torquatus) e a preguiça comum ou preguiça de garganta marrom (B. variegatus). Este trabalho foca-se sobretudo na última (Fig. 1). No entanto, neste trabalho, foram descritos novos dados genéticos para o estudo de preguiça de coleira e preguiça anã, que foram analisados e discutidos através de uma perspetiva comparativa com os dados de preguiça comum. Assim, considera-se importante uma breve introdução às preguiças de três dedos.

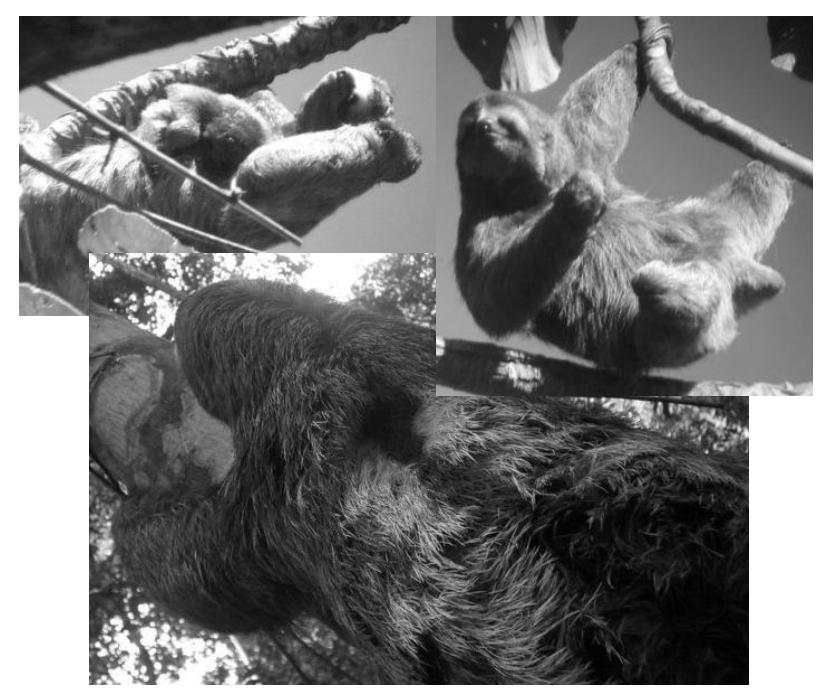

Figura 1.: Preguiça comum (Bradypus variegatus) na natureza.

A preguiça do norte, tal como o seu nome indica, ocorre a norte do rio Amazonas desde a Venezuela até à Guiana Francesa (Moraes-Barros et al. 2010). Esta espécie é considerada abundante, e portanto não possui estatuto de ameaçada. Mas na verdade é uma das preguiças de três dedos menos estudadas até hoje (Superina et al. 2010; Chiarello \& Moraes-Barros 2011).

Por sua vez, a preguiça anã é a mais recentemente descoberta. Esta espécie ocorre exclusivamente na Ilha Escudo de Veráguas, Panamá, de onde é endêmica (Anderson \& Handley 2001). Dado que a sua distribuição parece estar reduzida a cerca de $0.11 \mathrm{~km}^{2}$ de floresta de mangue vermelho fragmentada, é considerada severamente ameaçada (Superina et al. 2010; Anderson et al. 2011; Kaviar et al. 2012). Para além das publicações que a descrevem, e apesar do seu elevado grau de ameaça, ainda poucos estudos foram publicados sobre esta espécie (Superina et al. 2010; Anderson et al. 2011; Kaviar et al. 2012).

A preguiça de coleira é também endêmica. Neste caso, ocorre somente na Mata Atlântica. $\mathrm{O}$ seu estatuto de ameaça foi recentemente alterado de ameaçada para vulnerável, devido ao aumento na sua área de distribuição (Chiarello \& Moraes-Barros 2011; Hirsh \& Chiarello 
2011). Até à descoberta da preguiça anã, esta era a espécie de preguiça em maior risco. Por esse motivo diversos trabalhos de ecologia, genética e etologia foram já realizados, fazendo com que esta seja a espécie melhor conhecida (por exemplo Chiarello et al. 2004; Lara-Ruiz \& Chiarello 2005; Moraes-Barros et al. 2006; Lara-Ruiz et al. 2008).

Finalmente, a preguiça comum é amplamente distribuída pela região neotropical e portanto se estima que seja a mais abundante (Chiarello et al. 2011). A preguiça comum ocorre historicamente desde o sudeste Brasileiro até às Honduras (Moraes-Barros et al. 2010). Por esses motivos não é considerada ameaçada (Chiarello et al. 2011). No entanto, Emmons (1990) sugere que a espécie deveria possuir estatuto local de ameaça em biomas ameaçados como a Mata Atlântica. Adicionalmente, Phillips et al. (2006) detectaram a inexistência de condições para a ocorrência da espécie na região central do Brasil, devido sobretudo à ausência de floresta. De fato, as preguiças possuem hábitos estritamente arborícolas (Montgomery et al. 1973).

A ampla distribuição da preguiça comum repercutiu-se no seu estudo de dois modos distintos. Por um lado levou a que os pesquisadores se interessassem pela espécie desde há muito tempo e, portanto, diversos trabalhos tivessem já sido publicados. Dados sobre densidade de indivíduos, hábitos alimentares, diversidade genética, sistema reprodutivo, entre outros, estão descritos. Por outro lado, estes estudos são esparsos, algumas vezes não comparáveis, outras sem consenso, dada a sua fragmentação geográfica (limitam-se a pequenas áreas, outras de características muito particulares ou ainda em localizações muito dispersas) e embasamento em um baixo número amostral (por exemplo Greene 1989; Montgomery \& Sunquist 1975; Queiroz 1995; Moraes-Barros et al. 2006; Vaughan et al. 2007; Pauli \& Peery 2012).

\section{A preguiça comum na Mata Atlântica}

O primeiro trabalho sobre padrões de diversidade genética em preguiças comparou a diversidade genética de populações de preguiça comum da Mata Attântica com uma população de preguiça de coleira da Bahia. Através de DNA fingerprinting, este trabalho estimou uma baixa diversidade genética entre indivíduos de preguiça comum de São Paulo, sul da Mata Atlântica. No entanto, as populações da Bahia (região centro da Mata Atlântica) de ambas as espécies apresentavam níveis mais elevados e semelhantes entre si (Moraes-Barros et al. 2002). No seguimento, a descrição de um novo marcador genético nas preguiças (região controle do DNA mitocondrial; mtDNA) e uma maior amostragem populacional, ainda somente do bioma Atlântico, continuaram corroborando este cenário (Moraes-Barros et al. 2006). A descrição da variabilidade de DNA nuclear (nDNA) nas populações da Mata Atlântica possibilitou alargar o anteriormente descrito para este nível do genoma (Silva 2008). Porém, as duas porções nãocodificantes do genoma analisadas e, principlamente, os quatro (de um total de oito) microssatélites polimórficos descritos, não possibilitaram a avaliação da subestruturação populacional de preguiça comum na Mata Atlântica (Silva 2008). Concomitantemente, a 
avaliação de populações externas ao bioma permitiu distinguir que a baixa diversidade genética das populações de preguiça comum da Mata Atlântica se devia a eventos que teriam afetado particularmente estas populações, e não seriam característicos da espécie (Moraes-Barros et al. 2007; Silva 2008).

A par com a descrição dos níveis de diversidade genética, percebeu-se ainda uma forte diferenciação das populações de preguiça comum, distinguindo-se não só as populações Amazônicas das Atlânticas, bem como se detectou estruturação populacional dentro de cada bioma (Moraes-Barros et al. 2006, 2007; Silva 2008).

A falta de variabilidade genética e a baixa amostragem intra-populacional impossibilitaram um maior avanço no estudo genético destas populações (Moraes-Barros et al. 2006, 2007; Carnaval \& Moritz 2008; Silva 2008).

A diminuição da diversidade genética de norte para sul verificada tanto na preguiça comum da Mata Atlântica, como na preguiça de coleira (Moraes-Barros et al. 2006; Lara-Ruiz et al. 2008), bem como a divisão Norte / Sul descrita em diversos exemplos de vertebrados terrestres (Puorto et al. 2001; Costa 2003; Grazziotin et al. 2006), levam a crer que eventos comuns na história evolutiva do bioma poderiam estar na base destes resultados.

\section{Objetivos e Capítulos}

Neste contexto, surge o presente trabalho, focado nas populações de preguiça comum da Mata Atlântica, nos seus níveis de diversidade genética e na sua estruturação populacional. $O$ refinamento dos padrões de diversidade genética destas populações e a procura dos processos que estariam na sua origem levaram a que neste trabalho se incluíssem contribuições para o conhecimento do habitat e da espécie. Para tal utilizaram-se ferramentas não só de genética de populações, mas também de áreas como biogeografia, etologia e ecologia, numa perspetiva integrativa e comparativa. No final deste documento, reúnem-se as contribuições multidisciplinares que concluem a necessidade de conservação das populações de preguiça comum na Mata Atlântica.

Assim, esta tese encontra-se dividida em três temas principais: habitat, diversidade genética e biologia.

\section{O habitat}

Uma das motivações principais para estudar a Mata Atlântica, num trabalho focado em preguiça comum, foi o fato desta espécie ser um dos primeiros exemplos a originar uma das poucas hipóteses exclusivas para a distribuição da diversidade na Mata Atlântica - a hipótese dos dois-componentes (Costa et al. 2000; Moraes-Barros et al. 2006). Este dado ressaltou a relação entre a espécie e o bioma, e aguçou a perceção da necessidade de estudar ambos em conjunto, nomeadamente pelo apelo da conservação da vida selvagem. A Mata Atlântica é um 
hotspot de biodiversidade e um dos lugares mais ameaçados da Terra (Myers et al. 2000), principalmente devido ao desmatamento iniciado durante os Descobrimentos portugueses. Os estudos genéticos de preguiça comum indicam a baixa diversidade das populações Atlânticas de um animal deveras estranho e conspícuo, mas pouquíssimo estudado e biologicamente compreendido (Moraes-Barros et al. 2002, 2006; Silva 2008; Hayssen 2010). Além disso, os dois-componentes da Mata Atlântica foram sendo nomeados livremente como "norte" e "sul", e evidenciando-se como generalistas e abrangentes, dado que pareciam designar áreas distintas e ser transversais a inúmeros organismos. Daqui surgiu o primeiro grande objetivo deste estudo: definir e organizar o conhecimento sobre a distribuição da diversidade na Mata Atlântica. No Capítulo 2 testou-se a hipótese da existência de dois-componentes no bioma e esclareceram-se os padrões de distribuição da sua diversidade. Adicionalmente descreveram-se, exaustiva e abragentemente, os eventos potencialmente responsáveis por tais padrões, à luz do conhecimento atual. A organização da diversidade no bioma e o levantamento dos eventos na sua base contribuem para a interpretação dos padrões de diversidade genética de preguiça comum na Mata Atlântica.

\section{A diversidade genética}

O estudo anterior sobre a diversidade genética nuclear de preguiça comum na Mata Atlântica pouco contribuiu para aprofundar as causas da divisão norte/sul da espécie no bioma (Silva 2008). A baixa quantidade de amostras disponíveis, aliada a uma inesperada baixa diversidade genética em marcadores normalmente muito variáveis como os microssatélites (Jarne \& Lagoda 1996), revelaram-se insuficientes no detalhamento da estruturação e subestruturação das populações Atlânticas da espécie. No entanto, este trabalho começou a revelar que os diferentes níveis de diversidade de mtDNA e a diferenciação entre as populações da Mata Atlântica estariam marcados a nível nuclear (Moraes-Barros et al. 2006, 2007; Silva 2008). Assim impunha-se um novo esforço de descrição de mais marcadores nucleares. O segundo objetivo deste trabalho foi o aumento da bateria de marcadores nucleares descritos para a espécie. Os Capítulos 3 e 4 descrevem a variabilidade de um maior número de porções não-codificantes do genoma, de novas porções codificantes (dois) e de um maior número de microssatélites. Uma vez que a amostragem também se havia revelado um fator limitante, procurou-se aumentar o esforço amostral.

Especificamente, no Capítulo 3 testou-se se a baixa diversidade genética das populações de preguiça comum da Mata Atlântica estaria marcada também no genoma nuclear. Ainda, foi testado se esta característica seria exclusiva das populações Atlânticas, e se seria indicativo da necessidade de conservação destas populações. Assim compararam-se os níveis e padrões de diversidade genética nuclear em populações de preguiça comum Atlânticas com populações Amazônicas da espécie, e populações ameaçadas de preguiça de coleira e preguiça anã. Tanto 
quanto foi possível averiguar, a inclusão destas duas populações de outras espécies de preguiça faz deste trabalho o primeiro a avaliar a diversidade nuclear de preguiça de coleira e o primeiro estudo genético de preguiça anã.

Moraes-Barros et al. (2006) propuseram que os padrões de diversidade genética de preguiça comum na Mata Atlântica seriam explicados por uma sucessão de eventos, nomeadamente bottleneck, isolamento e expansão. No Capítulo 3 é levantada a hipótese, alternativa ou concomitante, de que a formação e manutenção de um sistema de metapopulações seriam responsáveis pela manutenção dos baixos níveis de diversidade genética na preguiça comum Atlântica. Estas duas hipóteses foram confrontadas no Capítulo 4. Após a descrição de uma bateria maior de microssatélites, testou-se qual das duas melhor explicaria os padrões de diversidade genética encontrados. Depois de inúmeras tentativas, finalmente foi possível avaliar a estruturação e subestruturação das populações de preguiça comum na Mata Atlântica. Este trabalho perrmitiu também analisar mais detalhadamente a demografia e a diversidade genética atuais destas populações.

O último capítulo sobre diversidade genética (Capítulo 5) surge na sequência da dificuldade técnica de escolha de uma bateria de microssatélites menor, mas informativa, quanto à diversidade genética das populações de preguiça comum. Mais de 50 marcadores do tipo microssatélite foram disponibilizados para o estudo da espécie (Capítulos 3 e 4). No entanto, por diversos motivos, a quantidade de amostra de alguns indivíduos tornou-se limitada no decorrer do trabalho. Assim, pensou-se em reduzir a quantidade de marcadores a genotipar.

Desde o seu início, este trabalho investigou, e esteve dependente ao longo do seu desenvolvimento, da diversidade genética das populações de preguiça comum da Mata Atlântica. Portanto a seleção do menor número de marcadores deveria evitar a perda de informação quanto a esta estimativa. O grau de polimorfismo do marcador, o sucesso e a facilidade na sua amplificação e genotipagem são os critérios comummente citados para seleção dos microssatélites (Heller et al. 2008; Nikolic et al. 2009; Kleven et al. 2012). Assim, questionou-se se a escolha de uma bateria menor, constituída pelos marcadores mais polimórficos, avaliaria a diversidade genética das populações de preguiça comum de modo semelhante à escolha aleatória do mesmo número de loci. Esta análise foi extendida à preguiça anã, pela amplificação cruzada dos marcadores descritos para a preguiça comum nesta espécie. Finalmente, dado que em genética da conservação, muitos estudos recorrem a amostragem não invasiva ou de espécimes de museu, possibilitando uma quantidade e qualidade limitadas de DNA (por exemplo Quéméré et al. 2010; Kleven et al. 2012), a possibilidade de usar o menor número de marcadores possível é relevante para outros organismos. Deste modo ampliou-se a análise a outros mamíferos com o objetivo de perceber se as consequências da seleção de microssatélites são transversais a diferentes espécies. 


\begin{abstract}
A biologia
Os trabalhos de campo realizados no âmbito deste estudo possibilitaram o testemunho de comportamentos de interação entre indivíduos de preguiça comum. As descrições aqui apresentadas parecem demasiado básicas e incompletas para serem dignas de uma publicação científica, principalmente quando comparadas com os trabalhos de ecologia e etologia de espécies não-Xenarthra. A necessidade de publicar estes registros está justificada pela falta de dados relativos ao comportamento da preguiça comum (revisto por Hayssen 2010). A título de exemplo, há somente um registro de comportamento reprodutivo (Bezerra et al. 2008) e pouco mais sobre cuidados parentais (Bezerra et al. 2008; Soares \& Carneiro 2002). Ademais, os trabalhos que reportam movimentos e posturas corporais de indivíduos de preguiça comum nomeiam de modo diferente o mesmo movimento/postura, dificultando comparações entre estudos (Queiroz 1995; Urbani \& Bosque 2006). No capítulo 6 para além de um relato de novos comportamentos para a espécie, uma tabela pormenorizada de posturas e movimentos é apresentada de modo a padronizar o estudo etológico deste animal.

A dificuldade na definição dos requerimentos biológicos e ecológicos da espécie prende-se com os seus hábitos arborícolas, lentos e silenciosos (revisto por Hayssen 2010) sendo difícil observar estes animais na natureza (Moraes-Barros com. pess.). No entanto, as instituições governamentais de conservação e preservação da vida selvagem, que recebem permanentemente animais silvestres, relatam a preguiça comum como uma das mais frequentes (Marius Belluci e Edson Víctor com. pess.). Os animais que chegam a estas instituições provêm de apreensões devido a cativeiro ilegal, resgates ou avaliações sanitárias de rotina. Os animais são comummente analisados por veterinários e devolvidos o mais rapidamente possível à natureza, sendo recolhidos dados como data e motivo de ocorrência, peso, sexo, faixa etária, estado sanitário, entre outros (ver instrução normativa 169/2008; Rocha-Mendes et al. 2006). O Capítulo 7 analisou os dados recolhidos por diversas das instituições mencionadas, localizadas ao longo da Mata Atlântica, e uniu o seu esforço amostral ao estudo biológico da preguiça comum. Este trabalho pretendeu avaliar a possibilidade da confirmação e obtenção de novos dados biológicos para a espécie a partir dos registros de ocorrência de instituições governamentais e estaduais brasileiras, nomeadamente dados relativos à época reprodutiva, sazonalidade de comportamentos, distribuição relativa da espécie, descrição de ameaças, entre outros.

Os últimos dois capítulos (Capítulos 6 e 7) objetivaram contribuir para um melhor entendimento dos requerimentos etológicos e biológicos da preguiça comum, para auxiliar a interpretação dos dados genéticos, trazendo assim mais uma contribuição para as ações de conservação de preguiça comum na Mata Atlântica.
\end{abstract}




\section{Referências}

Anderson RP, Handley CO. 2001. A new species of three-toed sloth (Mammalia: Xenarthra) from Panama, with a review of the genus Bradypus. Proceedings of the Biological Society of Washington 114: 1-33.

Anderson RP, Moraes-Barros N, Voirin B. 2011. Bradypus pygmaeus. In: IUCN 2012. IUCN Red List of Threatened Species. Versão 2012.2. www.iucnredlist.org. Downloaded a 15 de Novembro de 2012.

Auler AS, Wang X, Edwards RL, Cheng H, Cristalli PS, Smart PL, Richards DA. 2004a. Palaeoenvironments in semi-arid northeastern Brazil inferred from high precision mass spectrometric speleothem and travertine ages and the dynamics of South American rainforests. Speleogenesis and Evolution of Karst Aquifers 2: 1-4.

Auler AS, Wang X, Edwards RL, Cheng H, Cristalli PS, Smart PL, Richards DA. 2004b. Quaternary ecological and geomorphic changes associated with rainfall events in presently semi-arid northeastern Brazil. Journal of Quaternary Science 19: 693-701.

Ayres JM, Clutton-Brock TH. 1995. River boundaries and species range size in amazonian primates. The American Naturalist 140: 531-537.

Behling H. 2002. South and southeast Brazilian grasslands during Late Quaternary times: a synthesis. Palaeogeography, Palaeoclimatology, Palaeoecology 177: 19-27.

Bezerra BM, Souto AdS, Halsey L, Schiel N. 2008. Observation of brown-throated threetoed sloths: mating behaviour and the simultaneous nurturing of two young. Journal of Ethology 26: $175-178$.

Bush MB. 1994. Amazonian speciation: a necessarily complex model. Journal of Biogeography 21: 5-17.

Cabanne GS, d'Horta FM, Sari EH, Santos FR, Miyaki CY. 2008. Nuclear and mitochondrial phylogeography of the Atlantic forest endemic Xiphorhynchus fuscus (Aves: Dendrocolaptidae): biogeography and systematics implications. Molecular Phylogenetics and Evolution 49: 760-73.

Carnaval AC, Bates JM. 2007. Amphibian DNA shows marked genetic structure and tracks pleistocene climate change in northeastern Brazil. Evolution 61: 2942-57.

Carnaval AC, Moritz C. 2008. Historical climate modelling predicts patterns of current biodiversity in the Brazilian Atlantic forest. Journal of Biogeography 35: 1187-1201.

Ceballos G, Ehrlich PR. 2006. Global mammal distributions, biodiversity hotspots, and conservation. Proceedings of the National Academy of Sciences 103: 19374-9.

Ceballos G, Ehrlich PR. 2009. Discoveries of new mammal species and their implications for conservation and ecosystem services. Proceedings of the National Academy of Sciences 106: 3841-6. 
Chiarello AG, Chivers DJ, Bassi C, Maciel MAF, Moreira LS, Bazzalo M. 2004. A translocation experiment for the conservation of maned sloths, Bradypus torquatus (Xenarthra, Bradypodidae). Biological Conservation 118: 421-430.

Chiarello A, Moraes-Barros N. 2011. Bradypus torquatus. In: IUCN 2012. IUCN Red List of Threatened Species. Versão 2012.2. www.iucnredlist.org. Downloaded a 03 de Dexembro de 2012.

Chiarello A, Moraes-Barros N, Plese T. 2011. Bradypus variegatus. In: IUCN 2012. IUCN Red List of Threatened Species. Versão 2012.2. www.iucnredlist.org. Downloaded a 03 de Dexembro de 2012.

CNRBMA - Conselho Nacional da Reserva da Biosfera da Mata Atlântica (2009) Reserva da Biosfera da Mata Atlântica: revisão e atualização dos limites e zoneamento da Reserva da Biosfera da Mata Atlântica em base cartográfica digitalizada: fase VI. São Paulo, Brazil. 119 p.

Colinvaux PA, de Oliveira PE, Moreno JE, Miller MC, \& Bush MB. 1996. A long pollen record from lowland Amazonia: forest and cooling in glacial times. Science 274: 85-88.

Conservation International do Brasil, Fundação SOS Mata Atlântica, Fundação Biodiversitas, Instituto de Pesquisas Ecológicas, Secretaria do Meio Ambiente do Estado de São Paulo (SEMAD/Instituto Estadual de Florestas-MG). 2000. Avaliação e acções prioritárias para a conservação da biodiversidade da Mata Atlântica e Campos Sulinos. Brasília: MMA/SBF, 40p.

Costa LP. 2003. The historical bridge between the Amazon and the Atlantic Forest of Brazil: a study of molecular phylogeography with small mammals. Journal of Biogeography 30: 71-86.

Costa LP, Leite YLR, Fonseca GAB, Fonseca MT. 2000. Biogeography of South American forest mammals: endemism and diversity in the Atlantic forest. Biotropica 32: 872-881.

Cracraft J. 1985. Historical biogeography and patterns of differentiation within the South American avifauna: areas of endemism. Ornithological Monographies 36: 49-84.

De Oliveira PE, Barreto AMF, Suguio K. 1999. Late Pleistocene/Holocene climatic and vegetational history of the Brazilian caatinga: the fossil dunes of the middle São Francisco River. Palaeogeography, Palaeoclimatology, Palaeoecology 152: 319-337.

Ditchfield AD. 2000. The comparative phylogeography of neotropical mammals: patterns of intraspecific mitochondrial DNA variation among bats contrasted to non-volant small mammals. Molecular Ecology 9: 1307-18.

Emmons L. 1990. Neotropical rainforest mammals. Chicago: University of Chicago Press. $281 \mathrm{pp}$.

Endler JA. 1977 Geographic variation, speciation, and clines. Princeton, N.J.,Princeton University Press.

Fernandes DS, Franco FL, Fernandes R. 2004. Systematic revision of the genus Lachesis Daudin, 1803 (Serpentes, VIPERIDAE). Herpetologica 60: 245-260. 
Fundação SOS Mata Atlântica, INPE (Instituto Nacional de Pesquisas Espaciais). 2011. Atlas dos remanescentes florestais da Mata Atlântica, período 2008-2010. Fundação SOS Mata Atlântica e INPE, São Paulo, Brazil.

Grazziotin FG, Monzel M, Echeverrigaray S, Bonatto SL. 2006. Phylogeography of the Bothrops jararaca complex (Serpentes: Viperidae): past fragmentation and island colonization in the Brazilian Atlantic Forest. Molecular Ecology 15: 3969-82.

Greene HW. 1989. Agnostic behavior by three-toed sloths, Bradypus variegatus. Biotropica 21: $369-372$.

Haffer J. 1969. Speciation in amazonian forest birds. Science 165: 131-7.

Heller R, Lorenzen ED, Okello JB, Masembe C, Siegismund HR. 2008. Mid-Holocene decline in African buffalos inferred from Bayesian coalescent-based analyses of microsatellites and mitochondrial DNA. Molecular Ecology 17: 4845-58.

Hirsch A, Chiarello AG. 2011. The endangered maned sloth Bradypus torquatus of the Brazilian Atlantic forest: a review and update of geographical distribution and habitat preferences. Mammal Review 42: 35-54.

Hoorn C, Wesselingh FP, ter Steege H, Bermudez MA, Mora A, Sevink J, Sanmartín I, Sanchez-Meseguer A, Anderson CL, Figueiredo JP, Jaramillo C, Riff D, Negri FR, Hooghiemstra H, Lundberg J, Stadler T, Särkinen T, Antonelli A. 2010. Amazonia through time: Andean uplift, climate change, landscape evolution, and biodiversity. Science 330: 927931.

IBGE. 2011 Instituto Brasileiro de Geografia e Estatística; Ministério do Meio Ambiente. Mapa de Unidades de Conservação e Terras Indigenas na Área de Aplicação da Lei da Mata Atlântica. http://www.mma.gov.br/biomas/mata-atlantica/mapa-de-ucs-e-terras-indigenas. Downloaded a 23 de Março de 2013.

Jarne P, Lagoda PJ. 1996. Microsatellites, from molecules to populations and back. Trends in Ecology \& Evolution 11: 424-9.

Kaviar S, Shockey J, Sundberg P. 2012. Observations on the endemic pygmy three-toed sloth, Bradypus pygmaeus of Isla Escudo de Veraguas, Panama. PloS one 7: e49854.

Kleven O, Hallström BM, Hailer F, Janke A, Hagen SB, Kopatz A, Eiken HG. 2012. Identification and evaluation of novel di- and tetranucleotide microsatellite markers from the brown bear (Ursus arctos). Conservation Genetics Resources 4: 737-741.

Lara MC, Geise L, Schneider CJ. 2005. Diversification of small mammals in the Brazilian Atlantic forest of Brazil: testing the alternatives. In Lacey EA, Myers P, eds. Mammalian Diversification: From Chromosomes to Phylogeography (A Celebration of the Career of James L. Patton). University of California Publications in Zoology, University of California Press, 311-335. 
Lara-Ruiz P, Chiarello AG. 2005. Life-history traits \& sexual dimorphism of the Atlantic forest maned sloth Bradypus torquatus (Xenarthra: Bradypodidae). Journal of Zoology 267: 6373.

Lara-Ruiz P, Chiarello AG, Santos FR. 2008. Extreme population divergence and conservation implications for the rare endangered Atlantic Forest sloth, Bradypus torquatus (Pilosa: Bradypodidae). Biological Conservation 141: 1332-1342.

Lessa E, Cook J, Patton J. 2003. Genetic footprints of demographic expansion in North America, but not Amazonia, during the Late Quaternary. Proceedings of the National Academy of Sciences USA 100: 10331-10334.

Marroig G, Cerqueira R. 1997. Plio-Pleistocene South American history and the Amazon Lagoon hypothesis: a piece in the puzzle of Amazonian diversification. Journal of Comparative Biology. 2, 103-119.

Martins F, Ditchfield A, Meyer D, Morgante JS. 2007. Mitochondrial DNA phylogeography reveals marked population structure in the common vampire bat, Desmodus rotundus (Phyllostomidae). Journal of Zoological Systematics and Evolutionary Research 45: 372-378.

Martins F, Templeton A, Pavan AC, Kohlbach BC, Morgante JS. 2009. Phylogeography of the common vampire bat (Desmodus rotundus): marked population structure, Neotropical Pleistocene vicariance and incongruence between nuclear and mtDNA markers. BMC Evolutionary Biology 9: 294.

Miranda GB, Andrades-Miranda J, Oliveira LF, Langguth A, Mattevi MS. 2007. Geographic patterns of genetic variation \& conservation consequences in three South American rodents. Biochemical Genetics 45: 839-56.

Montgomery GG, Cochran WW, Sunquist ME. 1973. Radiolocating arboreal vertebrates in tropical forest. The Journal of Wildlife Management 37: 426-428.

Montgomery GG, Sunquist ME. 1975. Impact of sloths on Neotropical forest energy flow and nutrient cycling. Springer.

Moraes-Barros N, Giorgi AP, Silva SM, Morgante JS. 2010. Reevaluation of the geographical distribution of Bradypus tridactylus Linnaeus, 1758 and B. variegatus Schinz, 1825. Edentata 11: 53-61.

Moraes-Barros N, Miyaki CY, Morgante JS. 2007. Identifying management units in nonendangered species: the example of the sloth Bradypus variegatus Schinz, 1825. Brazilian Journal of Biology 67: 829-37.

Moraes-Barros N, Morgante JS, Miyaki CY. 2002. Genetic diversity in different populations of sloths assessed by DNA fingerprinting. Brazilian Journal of Biology 62: 503-8.

Moraes-Barros N, Silva JA, Miyaki CY, Morgante JS. 2006. Comparative phylogeography of the Atlantic forest endemic sloth (Bradypus torquatus) and the widespread three-toed sloth (Bradypus variegatus) (Bradypodidae, Xenarthra). Genetica 126: 189-98. 
Myers N, Mittermeier RA, Mittermeier CG, da Fonseca GA, Kent J. 2000. Biodiversity hotspots for conservation priorities. Nature 403: 853-8.

Nikolic N, Fève K, Chevalet C, Høyheim B, Riquet J. 2009a. A set of 37 microsatellite DNA markers for genetic diversity and structure analysis of Atlantic salmon Salmo salar populations. Journal of Fish Biology 74: 458-466.

Pauli JN, Peery MZ. 2012. Unexpected strong polygyny in the brown-throated three-toed sloth. PloS one 7: e51389.

Pessenda LCR, Gouveia SEM, Aravena R, Boulet R, Valencia EPE. 2004. Holocene fire and vegetation changes in southeastern Brazil as deduced from fossil charcoal and soil carbon isotopes. Quaternary International 114: 35-43.

Puorto G, Salomão MG, Theakston RDG, Thorpe RS, Warrell DA, Wüster W. 2001. Combining mitochondrial DNA sequences \& morphological data to infer species boundaries: phylogeography of lanceheaded pitvipers in the Brazilian Atlantic forest, and the status of Bothrops pradoi (Squamata: Serpentes: Viperidae). Journal of Evolutionary Biology 14: 527538.

Queiroz HL. 1995. Preguiças e guaribas: os mamíferos folívoros arborícolas do Mamirauá. Conselho Nacional de Desenvolvimento Científico e Tecnológico, Diretoria de Unidades de Pesquisa. Sociedade Civil Mamirauá, Brasília.

Quéméré E, Crouau-Roy B, Rabarivola C, Louis Jr EE, Chikhi L. 2010. Landscape genetics of an endangered lemur (Propithecus tattersalli) within its entire fragmented range. Molecular Ecology 19: 1606-1621.

Rocha-Mendes F, Napoli RPD, Mikich SB. 2006. Manejo, reabilitação e soltura de mamíferos selvagens. Arquivos de Ciências Veterinárias e Zoologia da Unipar 9: 105-109.

Silva MN, Patton JL. 1998. Molecular phylogeography and the evolution and conservation of Amazonian mammals. Molecular Ecology 7: 475-86.

Silva SM. 2008. Variação genética nuclear em duas espécies de mamíferos, a preguiça comum e o gambá de orelha preta, na Mata Atlântica (Brasil). Dissertação de Mestrado. Faculdade de Ciências. Universidade do Porto.

Soares CA, Carneiro RS. 2002. Social behavior between mothers x young of sloths Bradypus variegatus Schinz, 1825 (Xenarthra: Bradypodidae). Brazilian Journal of Biology 62: 249-52.

Steiner C, Catzeflis FM. 2004. Genetic variation and geographical structure of five mousesized opossums (Marsupialia, Didelphidae) throughout the Guiana Region. Journal of Biogeography 31: 959-973.

Superina M, Plese T, Moraes-Barros N, Abba AM. 2010. The 2010 Sloth Red List Assessment. Edentata 11: 115-134. 
Tchaicka L, Eizirik E, De Oliveira TG, Candido JF, Jr., Freitas TR. 2007. Phylogeography and population history of the crab-eating fox (Cerdocyon thous). Molecular Ecology 16: 81938.

Thomé MT, Zamudio KR, Giovanelli JG, Haddad CF, Baldissera FA, Alexandrino J. 2010. Phylogeography of endemic toads and post-Pliocene persistence of the Brazilian Atlantic Forest. Molecular Phylogenetics and Evolution 55, 1018-1031.

Urbani B, Bosque C. 2007. Feeding ecology and postural behaviour of the three-toed sloth (Bradypus variegatus flaccidus) in northern Venezuela. Mammalian Biology - Zeitschrift für Säugetierkunde 72: 321-329.

Vaughan C, Ramírez O, Herrera G, Guries R. 2007. Spatial ecology and conservation of two sloth species in a cacao landscape in limón, Costa Rica. Biodiversity and Conservation 16: 2293-2310.

Vilaça ST, Santos FR. 2010. Biogeographic history of the species complex Basileuterus culicivorus (Aves, Parulidae) in the Neotropics. Molecular Phylogenetics and Evolution 57: 585-97.

Wang X, Auler AS, Edwards RL, Cheng H, Cristalli PS, Smart PL, Richards DA, Shen CC. 2004. Wet periods in northeastern Brazil over the past $210 \mathrm{kyr}$ linked to distant climate anomalies. Nature 432: 740-3.

Webb TJ, Gaston KJ, Hannah L, \& Woodward IF. 2006. Coincident scales of forest feedback on climate and conservation in a diversity hot spot. Proceedings of the Royal Society B: Biological Sciences 273: 757-65. 


\title{
CAPítulo 2. Divide to conquer: a complex pattern of biodiversity depicted by vertebrate components in the Brazilian Atlantic Forest.
}

Sofia M. Silva, Nadia de Moraes-Barros, Camila C. Ribas, Nuno Ferrand \& João S. Morgante (2012). Biological Journal of the Linnean Society. 107: 39-55.

DOI:10.1111/j.1095-8312.2012.01919.x

\begin{abstract}
The identification of northern and southern components in different vertebrate species led researchers to accept a two-component hypothesis for the Brazilian Atlantic forest (BAF). Nevertheless, neither a formal proposal nor a meta-analysis to confirm this coincidence was ever made. Our main objective here was therefore to systematically test in how many vertebrate components the BAF could be divided by analysing existing empirical data. We used two approaches: (1) mapping and comparing the proposed areas of vertebrate endemism in the BAF and (2) analysing studies mentioning spatial subdivisions in distinct forest-dependent vertebrates within the biome, by the use of panbiogeography. The four large-scale endemism area components together with the six small-scale panbiogeographical ones allowed the definition of three $\mathrm{BAF}$ greater regions, subdivided into nine vertebrate components, latitudinally and longitudinally organized. Empirical time estimates of the diversification events within the BAF were also reviewed. Diversification of these vertebrates occurred not only in the Pleistocene but also throughout the Miocene. Our results confirm the BAF's complex history, both in space and time. We propose that future research should be small-scale and focused in the vertebrate components identified herein. Given the BAF's heterogeneity, studying via sections will be much more useful in identifying the BAF's historical biogeography.
\end{abstract}

\section{Keywords}

Biotic components - Brazilian Atlantic forest - Distribution patterns - Endemism areas Heterogeneous biome - Panbiogeography - Vertebrates.

\section{Introduction}

The Brazilian Atlantic forest (BAF) is considered the most threatened biodiversity hotspot in South America (Myers et al. 2000). The demand for agricultural land and cattle farms, and the rapid expansion of urban areas are amongst the major threats (Conservation International do Brasil et al. 2000). Nevertheless, the last estimates for the BAF biodiversity account approximately 20000 vascular plant species and over 2300 vertebrate species, half of the latter being endemic and about 150 with threatened status (Conservation International do Brasil et al. 2000). This biome includes all forest physiognomies from north-eastern Brazil to its south, 
including coastal Atlantic rain forests, semi-deciduous forests, subtropical Araucaria (Jussieu) forests and brejo forests (Oliveira-Filho \& Fontes, 2000; Fig. 1A).

In the last decade, interest in clarifying the origin of the BAF biodiversity has increased. The refugia hypothesis has been fully proposed and tested (Carnaval \& Moritz, 2008), but has proved to be insufficient to explain the diversification of the vertebrates (Martins, 2011). By contrast, the spatial organization of vertebrate diversity within and between taxa has been investigated by several studies, based both on molecular and on morphological data (e.g. Ditchfield, 2000; Costa, 2003; Lessa, Cook \& Patton, 2003; Faivovich et al. 2004; Carnaval et al. 2009). Consequently, different areas of vertebrate endemism were proposed within the BAF (Cracraft, 1985; Costa et al. 2000; Silva, Sousa \& Castelletti, 2004), and phylogeographical studies have shown the existence of distinct southern and northern clades in several vertebrate taxa (e.g. Puorto et al. 2001; Pellegrino et al. 2005; Grazziotin et al. 2006; Moraes-Barros et al. 2006; Martins et al. 2007). These findings resulted in a generally accepted hypothesis that the BAF comprises two latitudinal components of diversity (Costa, 2003; Moraes-Barros et al. 2006; Carnaval \& Moritz, 2008; Lara-Ruiz, Chiarello \& Santos, 2008). Even so, the geographical coincidence amongst all northern and southern vertebrate components and its relationship to the areas of endemism described was not tested. In fact, no formalization of the twocomponent hypothesis was ever made. The complexity of the BAF's biogeographical history is not a new idea (Cracraft \& Prum, 1988; Costa, 2003), and recent studies point to a more intricate scenario regarding vertebrate structure (e.g. Brunes et al. 2010; Thomé et al. 2010; D'Horta et al. 2011).

Here we aimed to test the two-component hypothesis through the use of panbiogeography. Panbiogeography is used to describe the distribution patterns of taxa (Croizat, 1952), and it has been recently used in the study of invertebrates (Nihei \& Carvalho, 2005; Löwenberg-Neto \& Carvalho, 2009), plants (Heads, 2008) and vertebrates (Arzamendia \& Giraudo, 2009). It can also be applied in evolution (Grehan \& Schwartz, 2009) and conservation (Prevedello \& Carvalho, 2006) studies, and in the description of a biome's biotic components, together with analysis of its areas of endemism (Morrone, 2009).

We therefore conducted a survey of the literature on vertebrate species distribution in the BAF focusing on: (1) summarizing vertebrate areas of endemism in the BAF, and (2) analysing the geographical coincidence of vertebrate diversity patterns described within the BAF. We also provide a comparative and integrative discussion focusing on patterns rather than processes and in light of our results and other biogeographical data. 

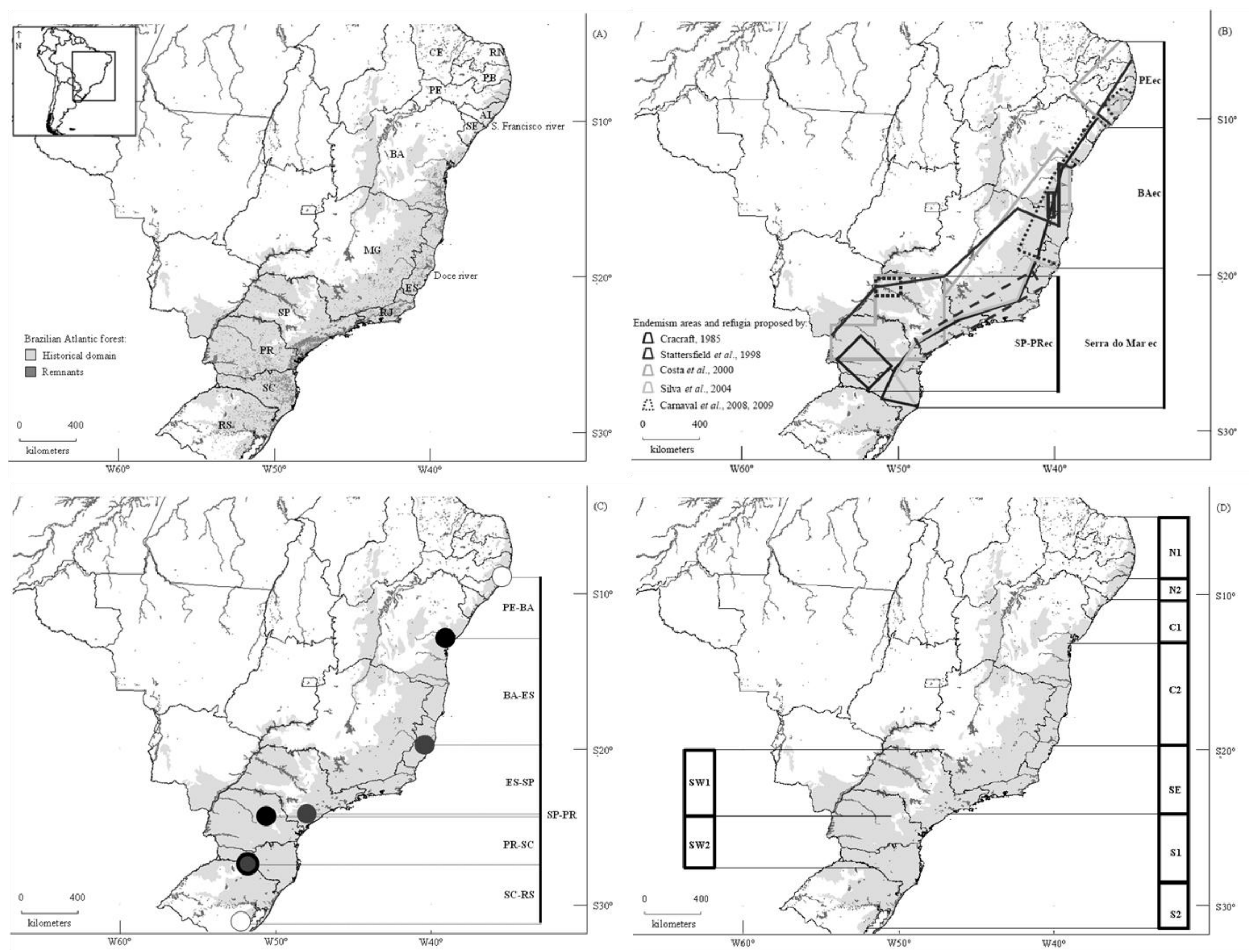
Figure 1. The Brazilian Atlantic forest (BAF) and the vertebrate components. A) BAF extension (CSR, 2007) and the location of the federal states mentioned in the text. B) geographical representation of the endemism areas and refugia proposed so far and their four most consensual biotic components, named after the literature: Pernambuco endemism component (PEec), Bahia endemism component (BAec), Serra do Mar endemism component (Serra do Mar ec), and São Paulo-Paraná endemism component (SP-PRec). C) convergence zones (nodes) found by the panbiogeographical analysis and their respective six biotic components. Convergence zones (nodes) were characterized by the convergence of two and three (white, PE and RS, respectively), four (black with grey, SC), six (grey, ES and SP) and more than ten (black, BA and PR) generalized tracks. D) our nine BAF vertebrate components, named with reference to their location. C2 (Centre 2) is coincident between endemism areas and panbiogeographical analyses. N1 (North 1), SW1 (Southwest 1) and S2 (South 2) are corroborated only by one analysis. All the others are supported by both analyses, at least to some extent. N, North; C, Centre; S, South; SE, Southeast; SW, Southwest. Abbreviations for Brazilian federal states (convergence zones and vertebrate components named thereafter): CE, Ceará; RN, Rio Grande do Norte; PB, Paraíba; PE, Pernambuco; AL, Alagoas; SE, Sergipe; BA, Bahia; MG, Minas Gerais; ES, Espírito Santo; RJ, Rio de Janeiro; SP, São Paulo; PR, Paraná; SC, Santa Catarina; RS, Rio Grande do Sul (see colored image on the page 168).

\section{Methods}

The ISI Web of Knowledge and the Google Scholar online databases of published studies were used to find studies mentioning a spatial differentiation in studies of the distribution and areas of vertebrate endemism in the BAF. The search was performed using mixed expressions including 'Brazilian Atlantic forest', 'endemism area', 'South America', 'vertebrates', and 'Brazil', and encompassed articles published until 31 August 2011. References in these publications were also checked.

As we intended to study the BAF we have only selected forest-dependent taxa (Porzecanski $\&$ Cracraft 2005). We focused our analysis on the study of vertebrates. Furthermore, we used the BAF definition of Oliveira-Filho \& Fontes (2000), so we excluded localities within gallery forests, although both forest types can be related (Costa 2003; Fernandes et al. 2004).

With regard to the first issue, i.e. to summarize the $\mathrm{BAF}$ areas of vertebrate endemism, the program DIVA-GIS version 7.1.7.2 and its draw shape tool (Hijmans et al. 2005) were used to map and represent the areas of endemism.

Secondly, we intended to test whether the BAF can be divided in the two northern and southern vertebrate components as recognized by researchers (e.g. Costa 2003; Moraes-Barros et al. 2006; Carnaval \& Moritz 2008; Lara-Ruiz et al. 2008). This was assessed and graphically represented using the panbiogeographical algorithm implemented in Martitracks (EcheverríaLondoño \& Miranda-Esquivel 2011).

To describe the BAF vertebrate components, we compared the resulting panbiogeographical pattern with that observed in the endemism area analysis.

\section{Individualized tracks}

The first step of a panbiogeographical analysis consists of drawing an individualized track for each taxon, representing its minimum probable distribution given the occurrence records 
input. This was done by using a new algorithm for the calculation of the minimum spanning tree, implemented in Martitracks (Echeverría-Londoño \& Miranda-Esquivel 2011).

If the BAF is divided into two components as previously recognized (e.g. Costa 2003; Moraes-Barros et al. 2006; Carnaval \& Moritz 2008; Lara-Ruiz et al. 2008), the majority of taxa are expected to be also divided into two subgroups. The subgroups analysed herein belonged to several taxonomic levels, from species and subspecies to populations and lineages. Consequently, each taxon will be represented by two individualized tracks, one in the north and one in the south of the BAF.

Irrespective of the amount of structure found in the surveyed studies, all works differentiating vertebrate distributions within the BAF were considered, defined by the use of either molecular or morphological markers. Likewise, we considered both BAF endemics and non-endemics, with either wide or restricted distribution in the BAF, as far as were structured within the biome. Thus, each component proposed by the selected studies corresponded to the subgroups defined here.

When necessary, authors were contacted to obtain the full list of localities and/or geographical coordinates mentioned in their studies. Furthermore, whenever the locality name was the only information available, coordinates were checked in the gazetteers accessible via the DIVA-GIS website (www.diva-gis.org). All coordinates were converted to UTM projection.

Some records were eliminated because they were repeated for the same subgroup, either in the same study or in different studies, or no coordinate matched the information available. Also, subgroups with fewer than two records were removed from the analysis, as just one locality recorded is insufficient to define an individualized track. Mixed localities, where the presence of specimens from different subgroups was detected, were multiplied in our dataset for each subgroup occurring there. The full list of groups, subgroups, localities and corresponding references analysed in the present study is provided in the Supporting Information (Table S1).

As sampling has been higher in the southern BAF, we diminished this asymmetry by eliminating redundant individualized tracks (Echeverría-Londoño \& Miranda-Esquivel 2011).

\section{Generalized tracks}

Overlapping of the individualized tracks is the second step of panbiogeography, originating generalized tracks, which result from the coincidence among taxa distributions (Croizat 1952). Generalized tracks can be interpreted as biotic components (Morrone 2009). Again, if there is only a northern and a southern component within the BAF (e.g. Costa 2003; Moraes-Barros et al. 2006; Carnaval \& Moritz 2008; Lara-Ruiz et al. 2008), we would expect to obtain two generalized tracks or at least two groups of generalized tracks, latitudinally organized.

This step was also done in Martitracks and tracks were drawn maintaining parameters as the default, except for minimum congruence, which was increased to 0.95. Raising minimum 
congruence and keeping the cut value and length parameters low allows us to find only the higher similarities between two subgroup distributions (Echeverría-Londoño \& MirandaEsquivel 2011).

\section{Nodes}

The last step in a panbiogeographic analysis is the identification and interpretation of nodes. Nodes were manually drawn where the convergence of two or more generalized tracks was depicted. As the location of the convergence was not a unique common locality but different close localities, our nodes represented complexes of nodes (Heads 2004). Also, given our aim of describing biotic components, nodes corresponded to the limits of biotic components, so we considered them as convergence zones (Heads 2004). Convergence of the distribution of taxa from distinct taxonomic levels in the same analysis means we are unable to interpret the temporal estimates of nodes. We therefore reviewed the time estimates published for the diversification events of the taxa analysed.

\section{Results}

\section{Brazilian Atlantic forest vertebrates' endemism components}

The areas of endemism for BAF vertebrates defined thus far are depicted in Fig. 1B. According to Haffer's (1969) refugia hypothesis, bird endemism areas are correlated with the refugia, so we also represented the three BAF refugia proposed by Carnaval et al. (Carnaval \& Moritz 2008; Carnaval et al. 2009) in our analysis of endemism areas.

The geographical location of the areas itself and the discussions made so far on this topic (Cracraft 1985; Marinho-Filho 1996; Stattersfield et al. 1998; Costa et al. 2000; Carnaval \& Moritz 2008; Carnaval et al. 2009; Passos et al. 2010) allowed us to identify four large-scale BAF endemism components, latitudinally and longitudinally organized (Fig. 1B). We named these components according to the consensus endemism area names given in the literature: Pernambuco endemism component (PEec), Bahia endemism component (BAec), Serra do Mar endemism component (Serra do Mar ec), and São Paulo - Paraná endemism component (SPPRec) (Fig. 1B).

\section{Brazilian Atlantic forest vertebrates' panbiogeographic components}

Our bibliographic search resulted in approximately 30 studies mentioning a vertebrate's latitudinal differentiation of distribution, including publications in scientifically indexed and non-indexed journals and $\mathrm{PhD}$ theses (Table 1). For the spatial panbiogeographical analysis, 23 of these references were used, concerning 22 taxa divided into 58 subgroups, with 37 being endemic, and resulting in 482 occurrence records (see Table S1). 
The Martitracks algorithm traced 58 individual tracks and 28 generalized tracks. We were able to group 22 generalized tracks in five overlapping regions (Fig. 2A-E). The other six generalized tracks could not be associated with any of these regions (Fig. 2F-I).

We were able to draw seven vertebrate panbiogeographical convergence zones, corresponding to the complexes of nodes. The convergence zones were divided into four classes of support: (1) PE and RS convergence zones were less supported, corresponding only to the convergence of two and three generalized tracks, respectively; (2) an SC convergence zone was supported by four generalized tracks; (3) Espírito Santo (ES) and SP convergence zones were supported by the convergence of six generalized tracks; and (4) with much higher support, above ten convergent generalized tracks, the nodes in BA and PR were drawn (Fig. 1C).

Considering both the nodes and location of generalized tracks, we defined six vertebrate panbiogeographical components latitudinally and longitudinally organized (Fig. 1C).

As mentioned in the Methods, temporal analysis of the nodes would not be informative, because of the broad taxonomic levels used in the same analysis. Nevertheless, according to the literature reviewed and considering our nomenclature, groups appear to have originated mostly during the Miocene and Pliocene. Their diversification within the BAF, corresponding to our subgroup formation, is most frequently dated to the Pliocene and the Pleistocene. Withinsubgroup diversification is the most common event during the Pleistocene, although some population expansions were also reported (Table 1 and references therein).

\section{Brazilian Atlantic forest vertebrates' components}

Based on the areas of endemism and panbiogeographical analyses we divide the BAF into three major latitudinally organized regions: Northerly BAF (from its northern limit to the São Francisco river), Central BAF (between the rivers São Francisco and Doce; Fig. 1D).

The Northerly BAF is a composite of two components. North 1 (N1) was only recovered by the endemism analysis and North 2 (N2) is limited by a highly supported panbiogeographical convergence zone and by the limit of several areas of endemism. This limit corresponds to the river São Francisco and separates the Northerly BAF from the Central region. We also found two components in the Central BAF, Central $1(\mathrm{C} 1)$ and Central $2(\mathrm{C} 2)$, which are divided by a highly supported convergence zone. Similarly, separation from the Southerly BAF is marked by a convergence zone supported by the convergence of six generalized tracks. The Southerly BAF shows longitudinal organization of its vertebrate components (Fig. 1D). Although Southwest 1 (SW1) is corroborated only by areas of endemism, the Southwest 2 (SW2) component is not only corroborated by the Paraná's centre of endemism (Cracraft 1985) but is also delimited by the convergence zones of PR and SC. Also, the Southeast (SE) component is corroborated by the Serra do Mar endemism areas (and the moderately supported convergence zones ES and SP). South 1 (S1) and South 2 (S2) are divided by the limits of bird endemism areas (Cracraft 
1985; Silva et al. 2004). S2 is supported only by panbiogeography, with the southern convergence zone being found in RS, the BAF's southern limit (Fig. 1B-D).

\section{Discussion}

The definition of components based on overlap of described areas of endemism was not as objective as that based on panbiogeography. Fewer studies were available concerning the latter, and considering very distinct geographical regions and scales. We were able to identify only large-scale components of BAF endemism, grouping smaller areas of endemism within the larger ones, and mostly based on arguments and discussions published to date (Cracraft, 1985; Marinho-Filho, 1996; Stattersfield et al. 1998; Costa et al. 2000, 2004; Carnaval \& Moritz, 2008; Carnaval et al. 2009; Passos et al. 2010; Fig. 1B).

The southern BAF endemism components were more difficult to delimit, as the overlap of endemism areas was less consensual. However, the evidence for bird endemism areas in the Serra do Mar (Stattersfield et al. 1998; Silva et al. 2004), the distinctiveness of this region compared with areas to the south-west (Cracraft, 1985), and the less pronounced differences found in the south-southwest area (Cracraft, 1985; Marinho-Filho, 1996; Costa et al. 2000; Carnaval \& Moritz, 2008; Carnaval et al. 2009; Passos et al. 2010) prompted us to divide these regions into two components (Fig. 1B). By contrast, the PEec is well supported by several areas of endemism (Stattersfield et al. 1998; Costa et al. 2000; Silva et al. 2004). Between the Serra do Mar ec and PEec we have delimited the BAec, limits of which are corroborated by Silva et al. (2004) and Carnaval et al. (Carnaval \& Moritz, 2008; Carnaval et al. 2009).

The broader scale of endemism area components is also related to the fact that their definition is focused on taxa at the species level, while panbiogeography can find patterns at a finer taxonomic scale (Morrone, 2009). Panbiogeography allows us to analyse not only endemism at a species' taxonomic level, but several taxonomic levels, either endemic or not. The two approaches are not expected to give coincident results, and instead they were compared because of their complementarity (Morrone, 2009). Thus, the four vertebrate components defined by the previously described areas of endemism, added to the six panbiogeographic vertebrate components identified here, allowed us to delimit nine vertebrates components grouped into three main regions (Fig. 1B-D).

This division is far from resembling the simple division into two components proposed earlier (e.g. Costa, 2003; Moraes-Barros et al. 2006; Carnaval \& Moritz, 2008; Lara-Ruiz et al. 2008). Furthermore, the vertebrate components identified herein are not only distributed latitudinally but also highlight an east-west differentiation. 
Table 1. Description of the studies reporting a differentiation in the forest-dependent vertebrates' distribution within the Atlantic forest. ${ }^{+}$Taxa used in the panbiogeographic analysis.

\begin{tabular}{|c|c|c|c|c|c|c|}
\hline & $\begin{array}{c}\text { Taxonomic } \\
\text { Group }\end{array}$ & $\begin{array}{c}\begin{array}{c}\text { No. of individuals } \\
\text { sampled }\end{array} \\
\end{array}$ & $\begin{array}{c}\begin{array}{c}\text { No. of localities } \\
\text { sampled }\end{array} \\
\end{array}$ & Taxonomic Subgroups & Time estimates (Myr) & Reference \\
\hline \multirow{3}{*}{$\frac{\mathscr{0}}{\stackrel{0}{2}}$} & $\begin{array}{l}\text { Bothrops } \\
\text { leucurus }\end{array}$ & $\begin{array}{l}104 \text { morphology } \\
18 \text { genetics }\end{array}$ & 7 & $\begin{array}{c}\text { - Bahia } \\
\text { - Espírito Santo }\end{array}$ & Without data & Puorto et al. 2001 \\
\hline & $\begin{array}{l}\text { Gymnodactylus } \\
\text { darwinii }^{+}\end{array}$ & 42 & 22 & $\begin{array}{c}\text { - Northern Doce river } \\
\text { - Between Doce and Paraguaçu rivers } \\
\text { - Southern Paraguaçu river } \\
\end{array}$ & Without data & $\begin{array}{l}\text { Pellegrino et al. } \\
\quad 2005\end{array}$ \\
\hline & $\begin{array}{l}\text { Bothrops } \\
\text { jararaca }^{+}\end{array}$ & 171 & 94 & $\begin{array}{l}\text { - From Espírito Santo to São Paulo } \\
\text { - From Paraná to Rio Grande do Sul }\end{array}$ & $\begin{array}{c}5.1 \text { to } 6.0 \text { (group formation) } \\
3.8 \text { (subgroups formation) } \\
0.14 \text { to } 0.76 \text { (diversification within } \\
\text { subgroups) } \\
0.1 \text { (southern subgroup expansion) }\end{array}$ & $\begin{array}{l}\text { Grazziotin et al. } \\
\quad 2006\end{array}$ \\
\hline \multirow{7}{*}{$\stackrel{0}{0}$} & Tangara & 7 & 4 & $\begin{array}{l}\text { - Alagoas (two species) } \\
\text { - Pernambuco } \\
\text { - São Paulo }\end{array}$ & 3.5 to 5.5 (group formation) & $\begin{array}{l}\text { Burns \& Naoki, } \\
\quad 2004\end{array}$ \\
\hline & $\begin{array}{l}\text { Xiphorhynchus } \\
\quad \text { fuscus }^{+}\end{array}$ & 114 (max.) & $26(\max )$ & $\begin{array}{l}\text { - Alagoas, Serras de Baturité and Ibiapaba } \\
\text { - Bahia and northern Minas Gerais } \\
\text { - Southern Minas Gerais and Rio de Janeiro } \\
\text { - From São Paulo to Rio Grande do Sul }\end{array}$ & $\begin{array}{c}3 \text { (group formation) } \\
0.11 \text { to } 0.79 \text { (subgroups formation) } \\
0.19 \text { (southern subgroup expansion) } \\
0.57 \text { (center subgroup expansion) }\end{array}$ & $\begin{array}{l}\text { Cabanne et al. } \\
2007,2008\end{array}$ \\
\hline & $\begin{array}{c}\text { Thamnophilus } \\
\text { ambiguous }^{+} \\
\end{array}$ & 22 & 10 & $\begin{array}{c}\text { - central Bahia and northeastern Minas Gerais } \\
\text { - Bahia, southeastern Minas Gerais and Espírito Santo }\end{array}$ & 0.9 to 3 (group formation) & Lacerda et al. 2007 \\
\hline & $\begin{array}{l}\text { Conopophaga }_{\text {lineata }^{+}}\end{array}$ & 77 & 21 & $\begin{array}{c}\text { - Southern Bahia to Northeastern Minas Gerais } \\
\text { - Southeastern Minhas Gerais to Northestern São Paulo } \\
\text { - São Paulo and Paraná } \\
\text { - Rio Grande do Sul to Misiones Argentina } \\
\end{array}$ & $\begin{array}{c}0.22 \text { to } 1.7 \text { (subgroups formation) } \\
0.04 \text { to } 0.18 \text { (southern subgroups } \\
\text { expansions) }\end{array}$ & \multirow[t]{2}{*}{ Pessoa, 2007} \\
\hline & $\begin{array}{l}\text { Conopophaga } \\
\text { melanops }\end{array}$ & 32 & 11 & $\begin{array}{l}\text { - Pernambuco and Alagoas } \\
\text { - Bahia to São Paulo } \\
\end{array}$ & $\begin{array}{c}0.04 \text { to } 0.65 \text { (subgroups formation) } \\
0.02 \text { to } 0.06 \text { (northern group expansion) } \\
0.01 \text { to } 0.09 \text { (southern group expansion) } \\
\end{array}$ & \\
\hline & $\begin{array}{l}\text { Sclerurus } \\
\text { scansor }^{+}\end{array}$ & 49 & 27 & $\begin{array}{c}\text { - Ceará } \\
\text { - from Bahia to the north of São Paulo } \\
\text { - from southern São Paulo to Rio Grande do Sul }\end{array}$ & $\begin{array}{c}1.12 \text { (group formation) } \\
0.09 \text { to } 0.60 \text { (subgroups formation) }\end{array}$ & D'Horta et al. 2011 \\
\hline & $\begin{array}{l}\text { Dendrocolaptes } \\
\text { platyrostris }^{+}\end{array}$ & 25 & 12 & $\begin{array}{l}\text { - Minas Gerais to São Paulo } \\
\text { - Paraná to Rio Grande do Sul }\end{array}$ & $\begin{array}{l}0.05 \text { (diversification within subgroups) } \\
<0.05 \text { (southern subgroup expansion) }\end{array}$ & Cabanne et al. 2011 \\
\hline
\end{tabular}


Taxonomic No. of individuals No. of localities Group sampled sampled

Taxonomic Subgroups

- Espírito Santo

\section{Thoropa}

miliaris

complex $^{+}$

137

Eleoscytalopus

indigoticus $^{+}$

indigoticust

Scytalopus $^{+}$

21

11

- São Paulo

- Juréia (São Paulo)

-São Paulo and Paran
Time estimates (Myr)

9 to 12 (group formation)

8.1 to 3.1 (subgroups formation)

0.2 to 4.7 (diversification within subgroups)

0.15 to 0.16 (southern subgroups expansion),

0.14 to 0.45 (northern subgroups retraction)

0.15 to 0.2 (northern subgroups expansion)

$$
6.2 \text { (groups formation) }
$$

2.4 (subgroups formation)

0.6 (diversification within subgroups)

$$
\text { - Paraná }
$$

\section{0 (groups formation)}

0.6 (diversification within subgroups)

- Paraná and Santa Catarina -Rio Grande do Sul

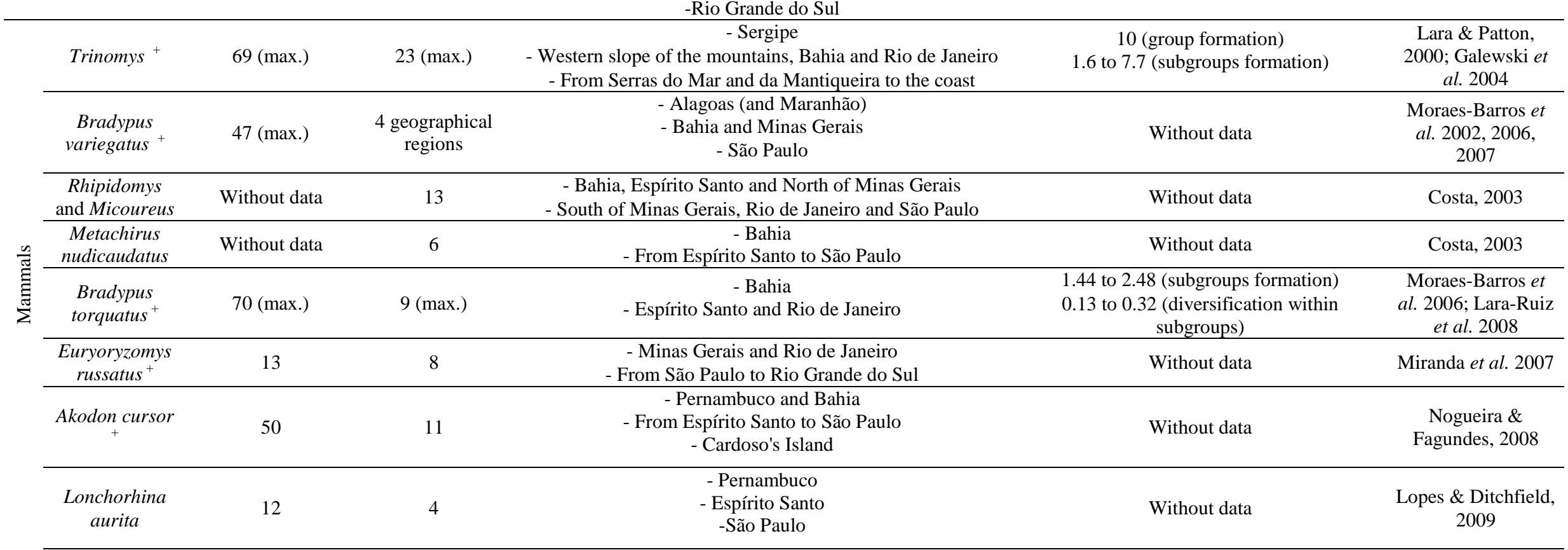


Taxonomic No. of individuals No. of localities Group sampled sampled

Time estimates (Myr)

\begin{tabular}{|c|c|c|c|c|c|c|}
\hline & Micoureus $^{+}$ & 23 (max.) & 7 & $\begin{array}{c}\text { - Bahia } \\
\text { - Minas Gerais and Rio de Janeiro }\end{array}$ & Without data & Dias et al. 2010 \\
\hline \multirow{4}{*}{ 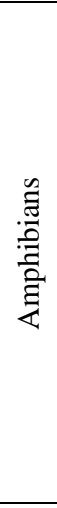 } & $\mathrm{Hyla}^{+}$ & Without data & 28 & $\begin{array}{c}\text { - Bahia and Minas Gerais } \\
\text { - From Espírito Santo to Paraíba do Sul river valley } \\
\text {-From Paraíba do Sul river valley to São Paulo } \\
\end{array}$ & Without data & Napoli, 2000, 2005 \\
\hline & $\begin{array}{l}\text { Hypsiboas } \\
\text { bischoffi }^{+}\end{array}$ & 269 & 34 & $\begin{array}{l}\text { - São Paulo and northern Paraná } \\
\text { - southern Paraná to Rio Grande do Sul }\end{array}$ & Without data & $\begin{array}{l}\text { Marcelino et al. } \\
2009\end{array}$ \\
\hline & $\begin{array}{l}\text { Phyllomedusa } \\
\text { burmeisteri } \\
\text { complex }^{+}\end{array}$ & 72 & 30 & $\begin{array}{l}\text { - From Sergipe to MinasGerais } \\
\text { - From Espirito Santo to São Paulo } \\
\text { - From São Paulo to Santa Catarina (eastern subgroup) } \\
\text { - From São Paulo to Santa Catarina (western subgroup) }\end{array}$ & $\begin{array}{c}5 \text { (group formation) } \\
1.6 \text { to } 2.5 \text { (subgroups formation) } \\
0.4 \text { (diversification within subgroups) }\end{array}$ & Brunes et al. 2010 \\
\hline & $\begin{array}{l}\text { Rhinella } \\
\text { crucifer group }\end{array}$ & 65 (max.) & 40 & $\begin{array}{c}\text { - Paraiba, Pernambuco and Bahia / Minas Gerais and } \\
\text { Espírito Santo } \\
\text { - Espírito Santo to Paraná / Santa Catarina } \\
\text { - Rio Grande do Sul } \\
\end{array}$ & $\begin{array}{c}6.26 \text { (group formation) } \\
0.84 \text { to } 3.97 \text { (subgroups formation) } \\
0.24 \text { to } 0.31 \text { (diversification within } \\
\text { subgroups) } \\
\end{array}$ & Thomé et al. 2010 \\
\hline
\end{tabular}

- Minas Gerais and Rio de Janeiro

Without data

Dias et al. 2010 


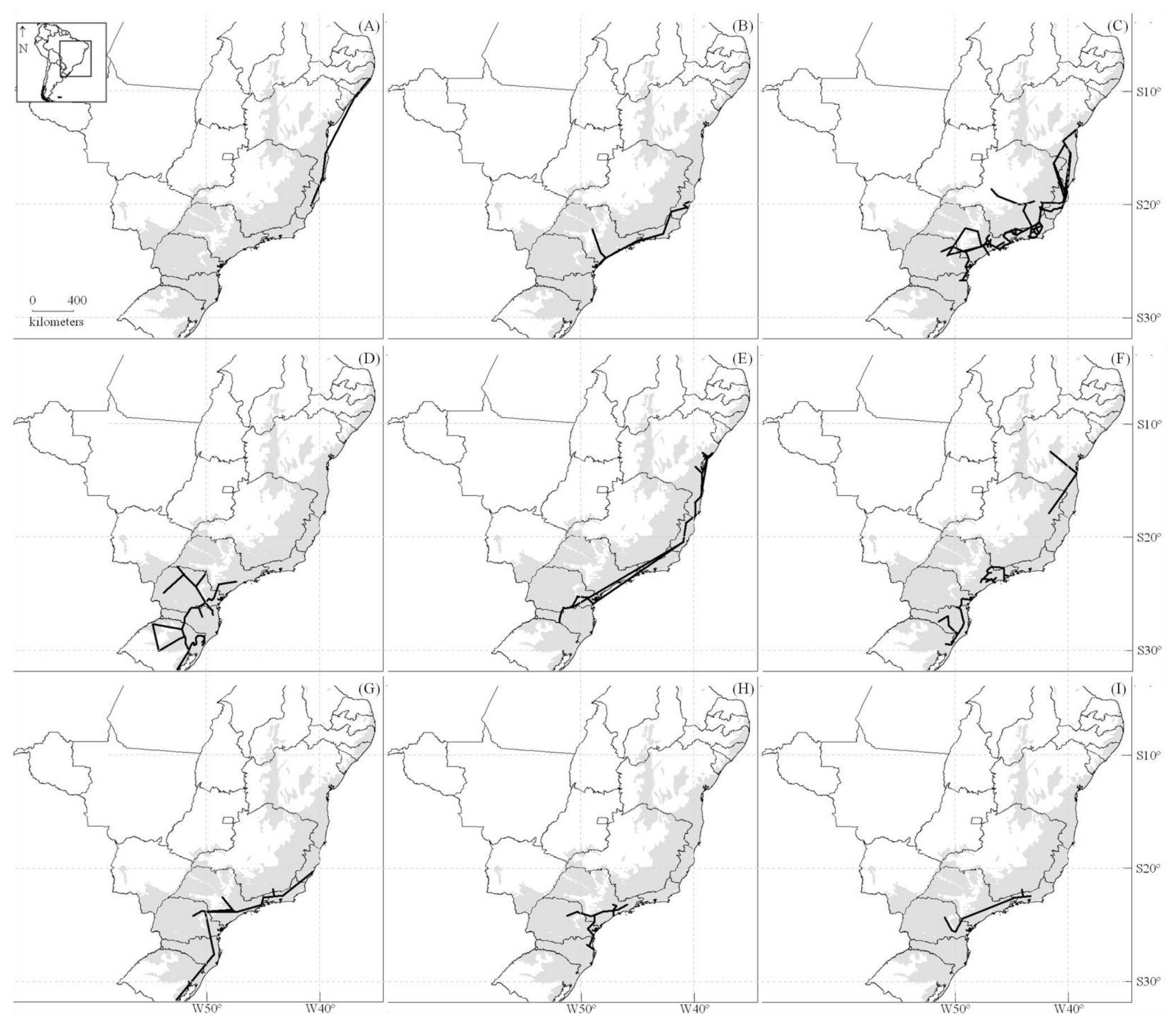


Figure 2. Generalized tracks obtained with a minimum congruence of 0.95 . A-E depict groups of two, three, 11, two and four generalized tracks with the same similarity index, respectively. F-I depict tracks that could not be grouped with any other.

In our panbiogeographic approach we had to use different taxonomic levels. Per se this already is indicative of complexity, suggesting that concurrent events in time were not responsible for the taxa diversification within the BAF. Consequently, we were not able to match the empirical time estimates reviewed with the formation of the components identified here. Yet our review highlights that vertebrate diversification events are older than previously thought. Refugia theory (Haffer, 1969) and Pleistocene climate changes are often cited as plausible explanations for the origin of vertebrate species or population structure in the BAF (e.g. Carnaval \& Moritz, 2008; Thomé et al. 2010). However, several diversification events are dated to as early as the Miocene (Galewski et al. 2004; Grazziotin et al. 2006; Fitzpatrick et al. 2009; Thomé et al. 2010; Table 1). This does not exclude a Pleistocene influence. Two wellsampled forest-dependent vertebrate groups diversified, expanded and lost genetic diversity probably in response to Pleistocene changes (D'Horta et al. 2011; G. S. Cabanne \& C. Y. Miyaki, unpubl. data).

The multitude of diversification events across both time and space, and the different population responses inferred from the studies cited here, leads us to agree with previous statements for the Amazonian forest (Bush, 1994). It is not likely that a simple event in such a small period of time (the Pleistocene epoch) would provide all the biodiversity found in the BAF.

The present work allows us to go beyond the assumption of complexity of the BAF, and to propose a hypothesis for the organization of its diversity. The biome's complexity is now reflected in the high number of vertebrate components herein described. We consider that is necessary to understand the diversifying processes that have affected the BAF by using smallscale studies before evaluating the larger events that influenced the biome as a whole. Our proposal is to divide the BAF focusing either on the biotic convergence zones or on the biotic components in future historical biogeography analyses. We believe that despite the amount of data already accumulated, it is not yet possible to propose a complete and consistent hypothesis for the origin of the BAF's biodiversity. However, our new approach to analyse the biome as partitioned here may bemore fruitful if given the evidence discussed below.

\section{The northerly Brazilian Atlantic forest - patchiness and climatic instability}

According to the areas of endemism, this region should be considered a unique component. Also, the convergence zone which divides the two components is supported only by the 
convergence of two generalized tracks, which meet from the south (Fig. 2A). Sampling available for the panbiogeographical analysis was limited in $\mathrm{N} 1$, with no coincident distributions, above the convergence zone (Fig. 2, supporting Table S1). In fact, the literature available largely relate to new species descriptions (Alves et al. 2006, 2009; Lingnau, Canedo \& Pombal Jr., 2008), with some species being reported only from their type localities (Canedo, Dixo \& Pombal, 2004; Carnaval \& Peixoto, 2004; Cruz \& Pimenta, 2004). In this context we believe that further studies are necessary to describe more accurate species distributions within this region, allowing better use of the panbiogeographical tools.

Nevertheless, we chose to describe two vertebrate components within the Northerly BAF, not only because of the panbiogeographical convergence zone, but also because this regions is shown to be one of the most important connection bridges between the Atlantic and the Amazonian forests for mammals (Costa, 2003; Moraes-Barros, Miyaki \& Morgante, 2007; Tchaicka et al. 2007) and for birds (Ribas \& Miyaki, 2004; Cabanne et al. 2008; Vilaça \& Santos, 2010) and for the colonization of the eastern Atlantic coast by amphibians (Carnaval \& Bates, 2007). Also, there is evidence that the northern Atlantic coast was the most probable route linking those forests (De Oliveira, Barreto \& Suguio, 1999; Silva \& Bates, 2002). So, a component influenced more by the connection with Amazonian forest, corresponding to N1, and another related more to the Atlantic forest itself, N2, seems to be more plausible. All taxa used in the present analyses are forest-dependent, so a connection must have been made through forest expansion. Nevertheless, some authors point to a forest spreading only in the Quaternary (Auler et al. 2004a, b), and others suggested that periods of major humidity favouring forest expansion could have been of short duration (Wang et al. 2004). Either way this territory seems to have been marked by a complex heterogeneous climate, with abrupt changes between wet and dry phases (Auler et al. 2004a; Wang et al. 2004). The Northerly BAF is even today marked by a climate that is strongly influenced by monsoons, being hot and arid in some areas and fully humid in others (Kottek et al. 2006). These climatic asymmetries resulted in a patchy landscape in which Atlantic montane forest enclaves, called brejos de altitude, occur surrounded by drier areas, mostly within the Caatinga biome. These enclaves are still present, even with the severe dry periods of this region (Hastenrath, Wu \& Chu, 1984).

Climatic instability and heterogeneity were probably responsible for speciation by local adaptation or allopatry, as climatic difference may have enhanced population isolation in less perturbed or less susceptible, smaller regions (Zamudio \& Green, 1997; Hewitt, 2000; Cabanne et al. 2008). Also, amphibian species appear to be highly structured (Carnaval, 2002) and the different communities seem to have been affected by past local events, climatic and landscape changes, experiencing different responses to these changes, either recolonization, extinction or 
population expansion. A diversifying process similar to the refuge theory (Haffer, 1969) would be a reasonable null hypothesis to be tested in this region.

This has been done considering the BAF as a whole, but given our results, a small-scale evaluation should be more valuable to disentangle the biogeographical history within the Northerly BAF. As we will demonstrate, other processes of diversification, distinct from the refugia hypothesis, may have been more important in the other BAF regions.

\section{The central Brazilian Atlantic forest - stability and the role of the Doce river}

In contrast to the two vertebrate components described for the Northerly BAF, the two Central vertebrate components are highly equally supported by the endemism areas analysis and panbiogeography. The convergence zone which divides the two components corresponds to the convergence of more than ten generalized tracks and the delimitation of this region is made by two biogeographically important rivers, the São Francisco and Doce. Both had been mentioned as limits of areas of endemism (Cracraft, 1985; Costa et al. 2000; Carnaval \& Moritz, 2008; Carnaval et al. 2009), and as potential barriers or taxa distribution limits (Pellegrino et al. 2005; Cabanne et al. 2008; Carnaval \& Moritz, 2008; Lara-Ruiz et al. 2008; Thomé et al. 2010).

The Central BAF has a clear vertebrate differentiation (Miranda et al. 2007; Lara-Ruiz et al. 2008) and hold greater genetic diversity (Marinho-Filho, 1996; Moraes-Barros et al. 2006; Cabanne et al. 2008, 2011; Fitzpatrick et al. 2009; Thomé et al. 2010; D’Horta et al. 2011) in comparison with the other BAF regions. As a consequence, many studies address this region as a stable area, for reptiles (Grazziotin et al. 2006), birds (Cabanne et al. 2008), amphibians (Carnaval \& Moritz, 2008; Fitzpatrick et al. 2009), and mammals (Carnaval et al. 2009).

This stability has been linked to rivers, particularly the Doce (Puorto et al. 2001; Pellegrino et al. 2005; Grazziotin et al. 2006). Based on these three studies, the role of the Doce river as a biotic convergence zone has been inferred (Cabanne et al. 2008; Carnaval \& Moritz, 2008; Lara-Ruiz et al. 2008; Thomé et al. 2010). However, no formal test was made to confirm the riverine barrier hypothesis (Ayres \& Clutton-Brock, 1995) in the BAF, and no alternative hypotheses were proposed to explain why the Doce river is a barrier to dispersal, whereas other major rivers are not (Pellegrino et al. 2005).

An alternative explanation for the distinct groups north and south of the Doce river may be related to distinct topographies. The north-east area is at lower altitude than the south-east (Oliveira-Filho \& Fontes, 2000). Immediately south of the Doce river are the two highest peaks of the BAF mountain ranges (> $2800 \mathrm{~m}$ ), in the hills of Caparaó (IBGE, 2006). And altitude is significantly correlated with species composition (Machado \& Fonseca, 2000), even in the 
southern Doce river (Lara \& Patton, 2000). Also vegetation and interspecies competition are factors influencing species distribution near the Doce river (Vilanova et al. 2005).

Across the low altitudes of the Central BAF river valleys, the lowland forest species could penetrate into the continent, over a larger area of suitable habitat (Oliveira-Filho \& Fontes, 2000). Low altitudes could also explain the more extended sea influence, resulting in the absence of marked climatic changes (Anhuf et al. 2006). In contrast to the Northerly BAF, the constancy of the climate must have enhanced diversification of taxa as a result of adaptation to micro-habitats available in this region. The Central BAF's vegetation richness (Martini et al. 2007) also favours this hypothesis, with the wide plant diversity supporting the diversification of all other organisms.

\section{The southerly Brazilian Atlantic forest - how recently was forested?}

The Southerly BAF has the highest number of vertebrate components proposed. On the one hand, areas of endemism were less concordant than in the other regions (see Discussion above). On the other hand, the number of distribution records available for the panbiogeographical analysis was higher in the southeast part of the region. Therefore, in SW1 less sampling was available for both analyses, prevailing the presence of a Pleistocene refugium in this region (Carnaval \& Moritz, 2008; Carnaval et al. 2009), and S2 is only supported by panbiogeography. The fact that several species have their limit of distribution in this region (IUCN, 2010) also contributed to defining the location of the convergence zone, as the panbiogeography mostly relate to taxa distributions (Croizat, 1952). All other components are corroborated by both analyses used.

Of note is the marked east-west differentiation, which was not previously highlighted, but is present in several studies analysed (Cracraft, 1985; Lara \& Patton, 2000; Brunes et al. 2010). This longitudinal organization is possibly a result of the more inland extension of the BAF within this region, despite evidence of an east-west differentiation also being present in the Central region, particularly in C2 (Fig. 1D; Lara \& Patton, 2000; Silva et al. 2004; Dias et al. 2010).

However, as explained in the previous section, the Central BAF probably evolved under climatic stability, given its low altitude. By contrast the Southerly BAF has the biome's highest mountain ranges (IBGE, 2006). These mountains are responsible for amphibian and bird lineages and species restriction and isolation within this area (Stattersfield et al. 1998; Burns \& Naoki, 2004; Grau et al. 2005; Napoli, 2005). The reason behind this isolation remains controversial. Uplift of the Serra do Mar and Mantiqueira mountain systems appears to be correlated with the isolation of forested-dependent mammals, differentiating the east from the 
west (Galewski et al. 2004; re-analyses of Lara, Geise \& Schneider, 2005). Conversely, evidence for recent population expansions corroborate a more recent onset of forest within the Southerly BAF (Grazziotin et al. 2006; Martins et al. 2007, 2009; Miranda et al. 2007; Cabanne et al. 2008, 2011; Fitzpatrick et al. 2009; D’Horta et al. 2011). Furthermore, support for this hypothesis is provided by the fact that the local topography seems to have suffered marked modification across time, as many river piracy events are evident (Oliveira \& Neto, 2007), and the signs of an intense tectonic activity are still apparent (reviewed by Saadi, 1993 and Ribeiro, 2006). These early topographic changes, the altitude itself and the past cold fronts from Antarctic in the late Quaternary made the Southerly BAF unsuitable for an exuberant forest on several occasions (reviewed by Behling, 2002), resulting in the current very distinct floristic pattern (Oliveira-Filho \& Fontes, 2000). Thus, geographical vicariance and ecological vicariance could have led to the vertebrate differentiation reported.

Moreover, the role of connectivity established by gallery forests remains unresolved. It seems to have promoted the dispersal of taxa between the Atlantic and the western Amazonian forests (Costa, 2003; Fernandes et al. 2004), or expansion of taxa within Cerrado and vice versa (Silva, 1996). A southern route of faunal exchange between the Atlantic and the Amazonia forests through the Pantanal is also supported (Costa, 2003; Martins et al. 2009).

Our review supports that shifts between isolation and connectivity characterize the distinct history of the Southerly BAF (Costa et al. 2000; Carnaval \& Moritz, 2008; Carnaval et al. 2009). But the time when these events occurred, and their influence on the distribution and extension of forest remains controversial.

\section{Conclusions}

This paper summarizes current knowledge on vertebrate diversity patterns within the BAF and help our understanding of its biogeographical history. Besides showing a latitudinal differentiation, the BAF has a considerably more complex and intricate structure than the northern and southern components previously suggested. We describe nine components grouped within three main regions, latitudinally and longitudinally organized, and transverse to several vertebrate taxa. We also show that this pattern was created throughout the Pleistocene, but earlier events, as early as the Miocene, also influenced the distribution and diversification of taxa. The previously proposed northern and southern divergence is probably due to poor sampling or in some cases is just an outcome pattern observed in species whose distribution is restricted to part of the BAF. We believe that analysing separately the BAF vertebrate components and convergence zones proposed herein will contribute more effectively to understanding the biome's biogeographical history. 


\section{Acknowledgements}

We thank Felipe Grazziotin, Felipe Martins, Fernando D'Horta, Gustavo Cabanne, João Alexandrino, Lucy Echeverría-Londoño, and Marcelo Napoli for sharing their results; Silvio Nihei for comments on the analyses; Joana Abrantes and Dr Michael Patten for providing valuable feedback on previous versions of this work; and the important comments provided by three anonymous reviewers. Finally we thank CTM/CIBIO and LABEC colleagues, who shared their opinions with the authors. S.M.S. is supported by a Foundation for Science and Technology PhD grant (SFRH/BD/40638/2007). N.M. has a CAPES-Prodoc fellowship in the Biosciences Institute, University of São Paulo.

\section{References}

Alves ACR, Ribeiro LF, Haddad CFB, dos Reis SF. 2006. Two new species of Brachycephalus (Anura: Brachycephalidae) from Brazilian Atlantic forest in Paraná state, southern Brazil. Herpetologica 62: 221-233.

Alves ACR, Sawaya RJ, dos Reis SF, Haddad CFB. 2009. New species of Brachycephalus (Anura: Brachycephalidae) from the Atlantic rain forest in São Paulo state, southeastern Brazil. Journal of Herpetology 43: 212-219.

Anhuf D, Ledru MP, Behling H, da Cruz FW, Cordeiro RC, van der Hammen T, Karmann I, Marengo JA, de Oliveira PE, Pessenda L, Siffedine A, Albuquerque AL, da Silva Dias PL. 2006. Paleo-environmental change in Amazonian and African rain forest during the LGM. Palaeogeography, Palaeoclimate, Palaeoecology 239: 510-527.

Arzamendia V, Giraudo AR. 2009. Influence of large South American rivers of the Plata Basin on distributional patterns of tropical snakes: a panbiogeogaphical analysis. Journal of Biogeography 36: 1739-1749.

Auler A, Wang X, Edwards L, Cheng H, Cristalli P, Smart P, Richards D. 2004a. Palaeoenvironments in semi-arid northeastern Brazil inferred from high precision mass spectrometric speleothem and travertine ages and the dynamics of South American rainforests. Speleogenesis and Evolution of Karst Aquifers 2: 1-4.

Auler A, Wang X, Edwards L, Cheng H, Cristalli P, Smart P, Richards D. 2004b. Quaternary ecological and geomorphic changes associated with rainfall events in presently semi-arid northeastern Brazil. Journal of Quaternary Science 19: 693-701.

Ayres JM, Clutton-Brock TH. 1995. River boundaries and species range size in Amazonian primates. The American Naturalist 140: 531-537.

Behling H. 2002. South and southeast Brazilian grasslands during Late Quaternary times: a synthesis. Palaeogeography, Palaeoclimatology, Palaeoecology 177: 19-27. 
Brunes T, Sequeira F, Haddad C, Alexandrino J. 2010. Gene and species trees of a Neotropical group of treefrogs: genetic diversification in the Brazilian Atlantic forest and the origin of a polyploid species. Molecular Phylogenetics and Evolution 57: 1120-1133.

Burns KJ, Naoki K. 2004. Molecular phylogenetics and biogeography of Neotropical tanagers in the genus Tangara. Molecular Phylogenetics and Evolution 32: 838-854.

Bush MB. 1994. Amazonian speciation: a necessarily complex model. Journal of Biogeography 21: 5-17.

Cabanne GS, D'Horta F, Meyer D, Silva JMC, Miyaki CY. 2011. Evolution of Dendrocolaptes platyrostris (Aves: Furnariidae) between the South American open vegetation corridor and the Atlantic forest. Biological Journal of the Linnean Society 103: 801-820.

Cabanne GS, D'Horta F, Sari E, Santos F, Miyaki CY. 2008. Nuclear and mitochondrial phylogeography of the Brazilian Atlantic forest endemic Xiphorhynchus fuscus (Aves: Dendrocolaptidae): Biogeography and systematics implications. Molecular Phylogenetics and Evolution 49: 760-773.

Cabanne GS, Santos F, Miyaki CY. 2007. Phylogeography and demographic history of Xiphorhynchus fuscus (Passeriformes: Dendrocolaptidae) in the southern Brazilian Atlantic forest of Brazil and Argentina. Biological Journal of the Linnean Society 91: 73-84.

Canedo C, Dixo M, Pombal Jr. JP. 2004. A new species of Chiasmocleis Méhelÿ, 1904 (Anura, Microhylidae) from the Atlantic rainforest of Bahia, Brazil. Herpetologica 60: 495-501.

Carnaval AC. 2002. Phylogeography of four frog species in forest fragments of northeastern Brazil—a preliminary study. Integrative and Comparative Biology 42: 913-921.

Carnaval AC, Bates JM. 2007. Amphibian DNA shows marked genetic structure and tracks Pleistocene climate change in Northeastern Brazil. Evolution 61: 2942-2957.

Carnaval AC, Moritz C. 2008. Historical climate modeling predicts patterns of current biodiversity in the Brazilian Atlantic forest. Journal of Biogeography 35: 1187-1201.

Carnaval AC, Peixoto OL. 2004. A new species of Hyla from northeastern Brazil (Amphibia, Anura, Hylidae). Herpetologica 60: 387-395.

Carnaval AC, Hickerson M, Haddad C, Rodrigues M, Moritz C. 2009. Stability predicts genetic diversity in the Brazilian Atlantic forest hotspot. Science 323: 785-789.

Conservation International do Brasil, Fundação SOS Mata Atlântica, Fundação Biodiversitas, Instituto de Pesquisas Ecológicas, Secretaria do Meio Ambiente do Estado de São Paulo, SEMAD/Instituto Estadual de Florestas - MG. 2000. Avaliação e ações prioritárias para a conservação da biodiversidade da Mata Atlântica e Campos Sulinos. Brasilia: Heringer H, Montenegro MM, Ministry of Environment, National Secretariat of Biodiversity and Forests. 
Costa LP. 2003. The historical bridge between the Amazon and the Brazilian Atlantic forest of Brazil: a study of molecular phylogeography with small mammals. Journal of Biogeography 30: 71-86.

Costa LP, Leite YLR, Fonseca GAB, Fonseca MT. 2000. Biogeography of South American forest mammals: Endemism and diversity in the Brazilian Atlantic forest. Biotropica 32: 872881.

Cracraft J. 1985. Historical biogeography and patterns of differentiation within the South American avifauna: areas of endemism. Ornithological Monographies 36: 49-84.

Cracraft J, Prum RO. 1988. Patterns and processes of diversification: speciation and historical congruence in some neotropical birds. Evolution 42: 603-620.

Croizat L. 1952. Vicariance/Vicariism, Panbiogeography, "Vicariance Biogeography," Etc.: A Clarification. Systematic Zoology 31: 291-304.

Cruz CAG, Pimenta BVS. 2004. New species of Physalaemus Fitzinger, 1826 from southern Bahia, Brazil (Anura, Leptodactylidae). Journal of Herpetology 38: 480-486.

CSR. 2007. Remote Sensing Centre - Brazilian Ministry of Environment. Available at http://siscom.ibama.gov.br/shapes/.

D'Horta F, Cabanne GC, Meyer D, Silva JMC, Miyaki CY. 2011. The genetic effects of Late Quaternary climatic changes over a tropical latitudinal gradient: diversification of an Atlantic Forest passerine. Molecular Ecology 20: 1923-1935.

Dias I, Almeida F, Amato G, DeSalle R, Fonseca C. 2010. Delineating geographic boundaries of the woolly mouse opossums, Micoureus demerarae and Micoureus paraguayanus (Didelphimorphia: Didelphidae). Conservation Genetics 11: 1579-1585.

Ditchfield A. 2000. The comparative phylogeography of Neotropical mammals: patterns of intraspecific mitochondrial DNA variation among bats contrasted to nonvolant small mammals. Molecular Ecology 9: 1307-1318.

De Oliveira PE, Barreto AMF, Suguio K. 1999. Late Pleistocene/Holocene climatic and vegetational history of the Brazilian caatinga: the fossil dunes of the middle São Francisco River. Palaeogeography, Palaeoclimatology, Palaeoecology 152: 319-337.

Echeverría-Londoño S, Miranda-Esquivel DR. 2011. MartiTracks: a geometrical approach for identifying geographical patterns of distribution. PlosOne 6: e18460.

Faivovich J, García P, Ananias F, Lanari L, Basso N, Wheeler W. 2004. A molecular putative perspective on the phylogeny of the Hyla pulchella species group (Anura, Hylidae). Molecular Phylogenetics and Evolution 32: 938-950.

Fernandes DS, Franco FL, Fernandes R. 2004. Systematic revision of the genus Lachesis Daudin, 1803 (Serpentes, Viperidae). Herpetologica 60: 245-260. 
Fitzpatrick S, Brasileiro C, Haddad C, Zamudio K. 2009. Geographical variation in genetic structure of an Atlantic Coastal Forest frog reveals regional differences in habitat stability. Molecular Ecology 18: 2877-2896.

Galewski T, Mauffrey J, Leite YLR, Patton JL, Douzery EJ. 2004. Ecomorphological diversification among South American spiny rats (Rodentia; Echimyidae): a phylogenetic and chronological approach. Molecular Phylogenetics and Evolution 34: 601-615.

Grau ET, Pereira SL, Silveira LF, Höfling E, Wajntal A. 2005. Molecular phylogenetics and biogeography of Neotropical piping guans (Aves: Galliformes): Pipile Bonaparte, 1856 is synonym of Aburria Reichenbach, 1853. Molecular Phylogenetics and Evolution 35: 637-645.

Grazziotin F, Monzel M, Echeverrigaray S, Bonatto S. 2006. Phylogeography of the Bothrops jararaca complex (Serpentes: Viperidae): past fragmentation and island colonization in the Brazilian Atlantic forest. Molecular Ecology 15: 3969-3982.

Grehan JR, Schwartz JH. 2009. Evolution of the second orangutan: phylogeny and biogeography of hominid origins. Journal of Biogeography 36: 101823-1844.

Haffer J. 1969. Speciation in Amazonian forest birds. Science 165: 131-137.

Hastenrath S, Wu M, Chu P. 1984. Towards the monitoring and prediction of north-east Brazil droughts. Quarterly Journal of the Royal Meteorological Society 110: 411-425.

Heads M. 2004. What is a node? Journal of Biogeography 31: 1883-1891.

Heads M. 2008. Panbiogeography of New Caledonia, south-west Pacific: basal angiosperms on basement terranes, ultramafic endemics inherited from volcanic islands arcs and old taxa endemic young islands. Journal of Biogeography 35: 2153-2175.

Hewitt G. 2000. The genetic legacy of the Quaternary ice ages. Nature 405: 907-913.

Hijmans RJ, Guarino L, Bussink C, Barrantes I, Rojas E 2005. DIVA-GIS, Version 7.1.7.2. Available at http://www.diva-gis.org.

IUCN. 2010. IUCN Red list of threatened species. Version 2010.1 available at www.iucnredlist.org.

Kottek M, Grieser J, Beck C, Rudolf B, Rubel F. 2006. World map of the Köppen-Geiger climate classification updated. Meteorologische Zeitschrift 15: 259-263.

Lacerda DR, Marini Mata Atlântica, Santos FR. 2007. Mitochondrial DNA corroborates the species distintiveness os the Planalto (Thamnophilus pelzelni Hellmayr, 1924) and the Sooretama (T. ambiguus Swainson, 1825) Slaty-antshrikes (Passeriformes: Thamnophilidae). Bazilian Journal of Biology 64: 873-882.

Lara MC, Patton JL. 2000. Evolutionary diversification of spiny rats (genus Trinomys, Rodentia: Echimyidae) in the Brazilian Atlantic forest of Brazil. Zoological Journal of Linnean Society 130: 661-686. 
Lara MC, Geise L, Schneider CJ. 2005. Diversification of small mammals in the Brazilian Atlantic forest of Brazil: testing the alternatives. In Lacey EA, Myers P, eds. Mammalian Diversification: From Chromosomes to Phylogeography (A Celebration of the Career of James L. Patton). University of California Publications in Zoology, University of California Press, 311-335.

Lara-Ruiz P, Chiarello AG, Santos FR. 2008. Extreme population divergence and conservation implications for the rare endangered Brazilian Atlantic forest sloth, Bradypus torquatus (Pilosa: Bradypodidae). Biological conservation 141: 1332-1342.

Lessa E, Cook J, Patton J. 2003. Genetic footprints of demographic expansion in North America, but not Amazonia, during the Late Quaternary. Proceedings of the National Academy of Sciences USA 100: 10331-10334.

Lingnau R, Canedo C, Pombal Jr. JP. 2008. A new species of Hylodes (Anura: Hylodidae) from the Brazilian Atlantic forest. Copeia 3: 595-602.

Löwenberg-Neto P, Carvalho CJ. 2009. Areas of endemism and spatial diversification of the Muscidae (Insecta: Diptera) in the Andean and Neotropical regions. Journal of Biogeography 36: $1750-1759$.

Machado RB, Fonseca GAB. 2000. The avifauna of Rio Doce valley, southeastern Brazil, a highly fragmented area. Biotropica 32: 914-924.

Marinho-Filho J. 1996. Distribution of bat diversity in the southern and southeastern Brazilian Atlantic forest. Chiroptera Neotropical 2: 51-54.

Martini A, Fiaschi P, Amorim A, Paixão J. 2007. A hot-point within a hot-spot: a high diversity site in Brazil's Brazilian Atlantic forest. Biodiversity Conservation 16: 3111-3128.

Martins F, Ditchfield A, Meyer D, Morgante JS. 2007. Mitochondrial DNA phylogeography reveals marked population structure in the common vampire bat, Desmodus rotundus (Phyllostomidae). Journal of Zooogycal Systematics and Evolutionary Research 45: 372-378.

Martins F, Templeton A, Pavan AC, Kohlbach B, Morgante JS. 2009. Phylogeography of the common vampire bat (Desmodus rotundus): Marked population structure, Neotropical Pleistocene vicariance and incongruence between nuclear and mtDNA markers. BMC Evolutionary Biology 9: 294-217.

Mata H, Fontana CS, Maurício GN, Bornschein MR, Vasconcelos MF, Bonatto SL. 2009. Molecular phylogeny and biogeography of the eastern Tapaculos (Aves: Rhinocryptidae: Scytalopus, Eleoscutalopus): cryptic diversification in Brazilian Atlantic forest. Molecular Phylogenetics and Evolution 53: 450-462. 
Miranda GB, Miranda JA, Oliveira LF, Langguth A, Mattevi MS. 2007. Geographic patterns of genetic variation and conservation consequences in there South American rodents. Biochemical Genetics 45: 839-856.

Moraes-Barros N, Morgante JS, Miyaki CY. 2002. Genetic diversity in different populations of sloths assessed by DNA fingerprinting. Brazilian Journal of Biology 62: 503-508.

Moraes-Barros N, Silva J, Miyaki CY, Morgante JS. 2006. Comparative phylogeography of the Brazilian Atlantic forest endemic sloth (Bradypus torquatus) and the widespread three-toed sloth (Bradypus variegatus) (Bradypodidae, Xenarthra). Genetica 126: 189-198.

Moraes-Barros N, Miyaki CY, Morgante JS. 2007. Identifying management units in nonendangered species: the example of the sloth Bradypus variegatus Schinz, 1825. Brazilian Journal of Biology 67: 829-83.

Morrone J. 2009. Evolutionary biogeography: an integrative approach with case studies. New York: Columbia University Press.

Myers N, Mittermeier RA, Mittermeier CG, da Fonseca GAB, Kent J. 2000. Biodiversity hotspots for conservation priorities. Nature 403: 853-858.

Napoli MF. 2000. Taxonomy, morphological variation and geographic distribution of Hyla circumdata (Cope, 1870) (amphibian, Anura, Hylidae) species group. Unpublished D. Phil. Thesis, Federal University of Rio de Janeiro.

Napoli MF. 2005. A new species allied to Hyla circumdata (Aura: Hylidae) from Serra da Mantiqueira, southeastern Brazil. Herpetologica 61: 63-69.

Nihei SS, Carvalho CJ. 2005. Distributional patterns of the Neotropical fly genus Polietina Schnabl \& Dziedzicki (Diptera, Muscidae): a phylogeny-supported analysis using panbiogeographic tools. Papéis Avulsos de Zoologia 45: 313-326.

Oliveira-Filho AT, Fontes MA. 2000. Patterns of floristic differentiation among Brazilian Atlantic forests in southeastern Brazil and the influence of climate. Biotropica 32: 793-810.

Oliveira D, Neto JP. 2007. Evolução do relevo na Serra do Mar no Estado de São Paulo a partir de uma captura fluvial. GEOUSP - Espaço e Tempo 22: 71-88.

Passos FC, Miranda J, Bernardi IP, Kaku-Oliveira N, Munster LC. 2010. Morcegos da região sul do Brasil: análise comparativa da riqueza de espécies, novos registros e atualizações nomenclaturais (Mammalia, Chiroptera). Iheringia 100: 25-34.

Pellegrino K, Rodrigues M, Waite A, Morando M, Yassuda Y, Sites Jr. J. 2005. Phylogeography and species limits in the Gymnodactylus darwinii complex (Gekkonidae, Squamata): genetic structure coincides with river systems in the Brazilian Atlantic forest. Biological Journal of the Linnean Society 85: 13-26. 
Pessoa RO. 2007. Systematic and Historical Biogeography of Conopophagidae (Aves: Passeriformes): Speciation in South American forests. D. Phil. Thesis, University of São Paulo.

Prevedello, JA \& Carvalho, C.. 2006. The Brazilian Cerrado conservation: the panbiogeographic methods as a tool for selecting priority areas. Natureza e Conservação, 4 , 127-145.

Porzecanski AL, Cracraft J. 2005. Cladistic analysis of distributions and endemism (CADE): using raw distributions of birds to unravel the biogeography of the South American aridlands. Journal of Biogeography, 32, 261-275.

Puorto G, Salomão DG, Theakston R, Thorpe R, Warrel DA, Wuster W. 2001. Combining mitochondrial DNA sequences and morphological data to infer species boundaries: phylogeography of lanceheaded pitvipers in the Brazilian Atlantic forest, and the status of Bothrops pradoi (Squamata: Serpentes: Viperidae). Journal of Evoutionary Biology 14: 527538.

Ribas CC, Miyaki CY. 2004. Molecular systematics in Aratinga parakeets: species limits and historical biogeography in the "solstitialis" group, and the systematic position of Nandayus nenday. Molecular Phylogenetics and Evolution 30: 663-675.

Ribas CC, Joseph L, Miyaki CY. 2006. Molecular systematic and patterns of diversification in Pyrrhura (Psittacidae), with special reference to the Picta-Leucotis complex. The Auk 123: 660-680.

Ribeiro AC. 2006. Tectonic history and the biogeography of the freshwater fishes from the coastal drainages of eastern Brazil: an example of faunal evolution associated with a divergent continental margin. Neotropical Ichthyoogy, 4, 225-246

Saadi A. 1993. Neotectônica da plataforma brasileira: esboço e interpretação preliminares. Geonomos 1: 1-15.

Silva JM. 1996. Distribution of amazonian and atlantic birds in gallery forests of the Cerrado region, South America. Ornitologia Neotropical 7: 1-18.

Silva JM, Bate, JM. 2002. Biogeographic patterns and conservation in the South American Cerrado: a tropical savanna hotspot. Bioscience 52: 225-233.

Silva JM, Sousa MC, Castelletti C. 2004. Areas of endemism for passerine birds in the Brazilian Atlantic forest, South America. Global Ecology and Biogeography 13: 85-92.

Stattersfield AJ, Crosby MJ, Long AJ, Wege DC. 1998. Endemic Bird Areas of the World: Priorities for Biodiversity Conservation. Cambridge (United Kingdom): BirdLife International.

Tchaicka L, Eizirik E, de Oliveira T, Cândido Jr. J, Freitas T. 2007. Phylogeography and population history of the crab-eating fox (Cerdocyon thous). Molecular Ecology 16: 819-838. 
Thomé MT, Zamudio K, Giovanelli J, Haddad C, Baldissera Jr. F, Alexandrino J. 2010. Phylogeography of endemic toads and post-Pliocene persistence of the Brazilian Atlantic forest. Molecular Phylogenetics and Evolution 55: 1018-1031.

Vilaça ST, Santos FR. 2010. Biogeophraphic history of the species complex Basileuterus culicivorus (Aves, Parulidae) in the Neotropics. Molecular Phylogenetics and Evolution 57: 585-597.

Vilanova R, Silva Jr. J, Grelle CE, Marroig G, Cerqueira R. 2005. Limites climáticos e vegetacionais das distribuições de Cebus nigritus e Cebus robustus (Cebinae, Platyrrhini). Neotropical Primates 13: 14-19.

Wang X, Auler A, Edwards L, Cheng H, Cristalli P, Smart P, Richard D, Shen C. 2004. Wet periods in northeastern Brazil over the past $210 \mathrm{kyr}$ linked to distant climate anomalies. Nature 432: 740-743.

Zamudio K, Green H. 1997. Phylogeography of the bushmaster (Lachesis muta: Viperidae): implications for Neotropical biogeography, systematics, and conservation. Biological Joumal of the Linnean Society 62: 421-442. 


\title{
CAPítulo 3. Study of populations as biodiversity components: the common and the endangered Bradypus sloths.
}

Sofia M. Silva, José Dávila, Bryson Voirin, Nuno Ferrand, João S. Morgante \& Nadia de Moraes-Barros (em preparação)

(Microssatélites e sequências dos introns dos genes beta-fibrinogênio e transferase da hipoxantina-guanosina fosforribosil desenvolvidos e inicialmente testados sobretudo nas populações do centro e sul da Mata Atlântica $(21 \leq \mathrm{n} \leq 36)$ por Silva, S. M. 2008. Variação genética nuclear em duas espécies de mamíferos, a preguiça comum e o gambá de orelha preta, na Mata Atlântica (Brasil). Dissertação de Mestrado. Faculdade de Ciências da Universidade do Porto, Porto. 84 pp.)

\begin{abstract}
Population diversity is an omnipresent component in biodiversity conservation. The study of populations is of particular interest in the neotropics, due to its biodiversity richness, and an escalating degree of deforestation. Bradypus sloths are charismatic examples of species whose populations caress detailed attention. The pygmy sloth (Bradypus pygmaeus) is a critically endangered species, namely because is restricted to one small isolated Panamanian island. However no genetic study has ever been made on this species. We compared pygmy sloth's genetic patterns to two other sloth species, the maned (B. torquatus) and the common sloths ( $B$. variegatus), through the use of newly described molecular markers, microsatellites and nuclear DNA sequences. The maned sloth is vulnerable to extinction and endemic to the disappearing Brazilian Atlantic forest (AF). The common sloth is the most widespread Bradypus species, and is not considered threatened, but occurs in menaced biomes, e.g. AF and Amazonia, where seems to be highly structured. This chapter confirmed the AF common sloth populations' distinctiveness and geographic isolation. Furthermore these populations had extremely low levels of genetic diversity, similar to the threatened pygmy and maned sloths' populations. We concluded that the correlation between the degree of threat and the genetic variability in Bradypus sloths is found at a population level rather than at a species level. We propose that the captivating nature of sloths would both be successfully used to preserve their populations and congeners, and also engage actions to the conservation of the AF itself.
\end{abstract}

\section{Keywords}

Atlantic forest - Common sloth - Maned sloth - Microsatellites - Nuclear DNA sequences Pygmy sloth - Three toed sloths 


\section{Introduction}

The world's biodiversity can be partitioned in three levels: ecological, organismal and genetic diversities (Heywood 1995). However, population diversity, a component transversal to all biodiversity levels, has received particular consideration in conservation biology (Hughes et al. 1997; Luck et al. 2003; Skrbinsek et al. 2012). Researchers realized that the loss of a population may be disastrous for the ecosystem at a local scale (Vitousek 1990; McConkey \& Drake 2006), and can jeopardize the entire species survival at a broader extent (Ehrlich \& Daily 1993), particularly by the loss of the species' genetic diversity, which reduces its evolutionary capacity (Wright 1977; Lacy 1987). Moreover, attending to populations' loss and to its genetic depauperation can reveal a species that is endangered (Ceballos \& Ehrlich 2002; Spielman et al. 2004; Frankham 2005). Conservationists have mainly studied the consequences of genetic variability losses in small isolated wild populations, which are known to have suffered severe demographic bottlenecks (Westemeier et al. 1998; Groombridge et al. 2000; Neuwald 2010; Sonsthagen et al. 2012). However, despite large populations are not the focus of conservation actions, their study contributes to a better assessment of the populations' structure, their dynamics, and may highlight geographically restricted portions of genetic diversity distributed in threatened areas.

Studying populations within lower latitudes is of particular interest. First, the overall ecosystem services of tropical environments are well known (Ricketts 2004; Bunker et al. 2005). Secondly, this is the world's most biodiverse region (reviewed by Willig et al. 2003). Thirdly, populations' loss and degree of threat are higher within the tropics (Hughes et al,. 1997; Myers et al. 2000; Ceballos \& Ehrlich 2002). Finally, the information available to conservation actions is still the poorest (Collen et al. 2008).

Within South America, the Brazilian Atlantic forest (AF) has one of the highest mammals species' richness (Buckley et al. 2010), but is highlighted as the most menaced biodiversity hotspot (Myers et al. 2000), being continuously disappearing during the last 500 years (Conservation International do Brasil et al. 2000, Fundação SOS Mata Atlântica \& INPE 2011).

Previous studies on two of the most appealing AF species found that, within the biome, both the common (Bradypus variegatus), and the maned sloths' (B. torquatus) populations had low levels of mitochondrial DNA diversity (Moraes-Barros et al. 2006; Lara-Ruiz et al. 2008). These populations were genetically distinct and geographically isolated (Lara-Ruiz et al. 2008; Hirsch \& Chiarello 2011; Moraes-Barros et al. 2007, 2011). For the common sloth, a widespread species (Moraes-Barros et al. 2010), the most profound populations' genetic divergence observed was precisely between the Amazonian forest (AMZ) and the AF (MoraesBarros et al. 2011). 
The common sloth is considered of least concern, despite the pronounced population structure, the signs of genetic depauperation within AF populations, and the significant AF destruction that has enhanced population fragmentation therein (Moraes-Barros et al. 2007, 2010; Chiarello et al. 2011; Fundação SOS Mata Atlântica \& INPE 2011). Thus, this low-risk category attributed to the species as a whole seems to be misleading at the population diversity level. Conversely, the maned sloth is listed as vulnerable to extinction, and considered to be declining together with the AF, to which is endemic (Chiarello \& Moraes-Barros 2011). Given that a depleted genetic diversity is correlated with reduced population fitness (Reed \& Frankham 2003; Markert et al. 2010), alarming signs of low long-term adaptability can be drawn from mtDNA results for the vulnerable maned sloth and the common sloth $\mathrm{AF}$ populations. However, a more extensive evaluation of its genetic diversity and differentiation is necessary, since only the mtDNA molecule was evaluated (Lara-Ruiz et al. 2008; MoraesBarros et al. 2006). Notwithstanding, the most threatened sloth species is the pygmy sloth ( $B$. pygmaeus; Anderson et al. 2011). It is endemic to the red mangrove forest in Isla Escudo de Veráguas, Panama (Anderson \& Handley 2002). This species is restricted to $4.2 \mathrm{~km}^{2}$, and is considered as critically endangered (Anderson et al. 2011), but no genetic investigation on this species was ever made.

In this context, the present work describes new molecular markers, both microsatellites and nuclear DNA sequences, applied to the study of AF common sloth populations, as well as maned's and the pigmy's sloths. We extend previous B. variegatus mtDNA analysis by increasing sampling, re-evaluating populations' low genetic variability, and revisiting its demographic signs of expansion and isolation in light of the new molecular data. Furthermore we compare the genetic diversity of the AF common sloth populations to the AMZ population and two other sloth species, being the first genetic study on the pygmy sloth. Finally we evaluate populations' biodiversity level by integrating data on genetic diversity, demographic history and degree of isolation (Luck et al. 2002; Höglund 2009).

\section{Material and methods}

\section{Sampling}

Sixty-five common sloth samples were collected in different AMZ and AF fragments (Fig.1, Table 1, S1). We also included sixteen maned sloth and fifteen common sloth samples previously studied by Moraes-Barros et al. (2006, 2007). Ten pygmy sloth samples from their unique population were also analyzed. 


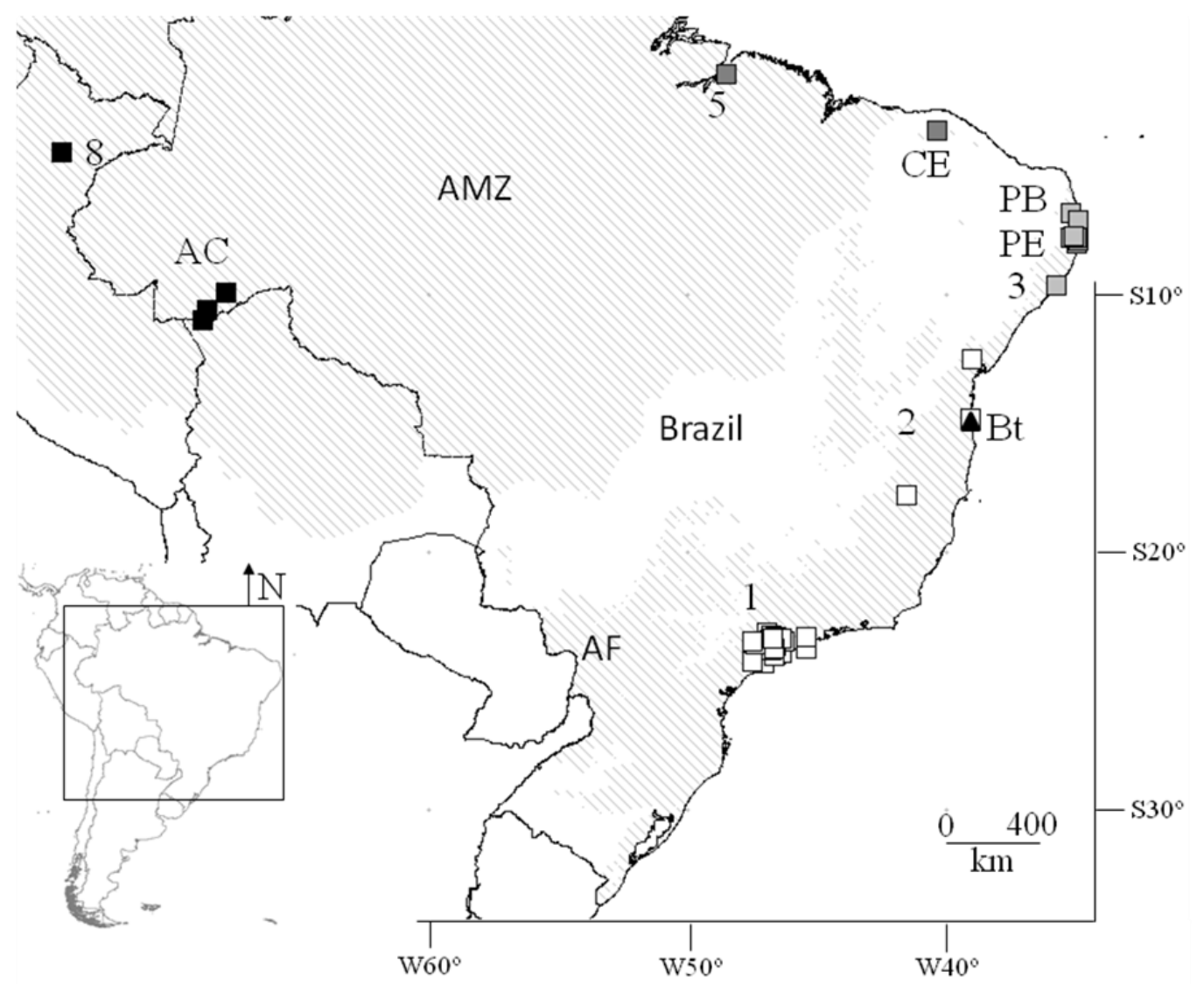

Figure 1. Sampling localities and representation of Atlantic (AF) and Amazonian Forests (AMZ; Utah Public Lands Research 2005). The black triangle corresponds to the Bahia's maned sloth populations ( $B$. torquatus, Bt). Common sloth's (B. variegatus) sampling geographic regions (GR) were numbered according to Moraes-Barros et al. (2007). White squares correspond to GR1 and GR2, and central/southern AF population (AFCS). Light grey squares identify sampling within GR3, Pernambuco (PE) and Paraíba (PB) localities and correspond to northeastern AF population (AFNE). Dark grey squares correspond to Ceará (CE) and GR5, and AMZEast population. Black squares correspond to Acre (AC) and GR8, and AMZWest population. The pygmy sloth (B. pygmaeus) occurs only in Isla Escudo de Veráguas, Panama (not shown).

Blood, bucal swabs or hair samples were obtained from either captive individuals (of known origin), wild animals captured for sanitary analyses or for this study. Sampling from live animals was performed in the less stressful way. We also collected tissue samples from carcasses and preserved it in ethanol. Samples were obtained under Brazilian Environment Ministry (IBAMA) permission (no. 19267-3/14597869). Genomic DNA was extracted by a saline protocol, with minor modifications for blood and hair samples (Sambrook et al. 1989). Genomic DNA collection and extraction with bucal swabs were performed with Oragene Animal Kits (Oragene $\left.{ }^{\circledR}\right)$, following the manufacture's protocol. 


\section{Molecular markers}

We describe here new molecular markers which were selected from the common sloth genome. These markers were tested to verify successful amplification on the maned and the pygmy sloth. Because not all loci were amplified in the total dataset, genetic diversity analyses were performed on subsets of loci, species, and populations. In the multiloci analysis, missing data has been reduced by excluding samples that had at least one microsatellite locus and two nuclear DNA sequences missing (Tables 1 and S1).

Table 1. Sampling information per species and per molecular analysis. Different datasets were used due to different amplification and/or sequencing success. In the multiloci analysis, missing data has been reduced by excluding samples that had at least one microsatellite locus and two nuclear DNA sequences missing. Common sloth (Bradypus variegatus) geographical regions (GR) are numbered after MoraesBarros et al. (2007) whenever it corresponded. Micros - Microsatellite loci; FGB - beta-fibrinogen; RAG2 - recombination activating 2; HBB - beta-globin; HPRT - hypoxanthine-guanosine phosphoribosyl transferase; PLP1 - proteolipid protein 1.

\begin{tabular}{ccccccccc} 
& & \multicolumn{7}{c}{ No. of samples analyzed } \\
Species & GR & Micros & FGB & HBB & RAG2 & HPRT & PLP1 & MultiLoci \\
\hline Pygmy sloth & Isla Escudo, Panama & 7 & 10 & 9 & 8 & 7 & 9 & 0 \\
Maned sloth & Bahia, Brazil & 0 & 12 & 12 & 9 & 10 & 14 & 0 \\
& 1 & 31 & 20 & 15 & 9 & 14 & 23 & 21 \\
& 2 & 8 & 8 & 7 & 6 & 8 & 8 & 8 \\
& 3 & 8 & 4 & 3 & 2 & 2 & 4 & 4 \\
Common sloth & Pernambuco, PE, Brazil & 13 & 6 & 6 & 4 & 9 & 7 & 9 \\
& Paraíba, PB, Brazil & 2 & 2 & 1 & 2 & 2 & 3 & 2 \\
& Ceará, CE, Brazil & 2 & 1 & 1 & 1 & 1 & 1 & 1 \\
& 5 & 6 & 6 & 4 & 6 & 6 & 5 & 6 \\
& Acre, AC, Brazil & 4 & 4 & 2 & 2 & 4 & 4 & 4 \\
& 8 & 1 & 1 & 1 & 0 & 1 & 1 & 1 \\
\hline
\end{tabular}

Microsatellite data

We constructed a partial genomic microsatellite enriched library using the DNA from three common sloth males from southern AF. DNA was digested with: AluI and RsaI - digestion 1; RsaI, HincII and SmaI - digestion 2; and BsuRI and Eco32I - digestion 3. The three digestions occurred separately at optimal conditions, but were mixed together when finished. After electrophoresis, fragments measuring between 1000 and 3000 base pairs (bp) were extracted from agarose gel with QIAquick Gel Extraction kit (QIAGEN®). Then DNA was dephosphorilated with Calf Intestine Alkaline Phosphatase (New England Biolabs®) and purified with MinElute PCR Purification kit (QIAGEN@). Fragments were bound into SNX linkers and a PCR was performed to ensure successful ligation following Hamilton et al. (1999). 
Dynabeads (Dynal $®$ ) were used to capture PCR products containing microsatellites. The biotinylated probes used were: $(\mathrm{AC})_{13},(\mathrm{AG})_{14},(\mathrm{AAAG})_{7}$ and $(\mathrm{GATA})_{7}$.

Captured DNA was amplified in $20 \mu \mathrm{L}$ of a mixture containing $1 \mu \mathrm{L}$ of template (about 20ng), 1.5x PCR buffer; $3.75 \mathrm{mM} \mathrm{MgCl}_{2} ; 10 \mu \mathrm{M}$ SNX F primer; 0.5mM dNTPs; TaqDNA polymerase $0.05 \mathrm{U}$. Thermal cycler conditions were: an initial denaturation of $94^{\circ} \mathrm{C} 2 \mathrm{~min}$, followed by 35 cycles of $94^{\circ} \mathrm{C} 30 \mathrm{sec} ., 62^{\circ} \mathrm{C} 30 \mathrm{sec}$, $72^{\circ} \mathrm{C} 30 \mathrm{sec}$, then a final dwell of $72^{\circ} \mathrm{C} 2$ min. Products were checked by agarose gel electrophoresis. PCR fragments were cloned into pUC19 plasmids and used to transform JM109 High Efficiency Competent Cells (Promega ${ }^{\circledR}$ ) following the manufacturer. The first clone selection was made on LB-ampicillin and X-gal agar plates. Transformed clones were transferred to LB-ampicilin agar numbered plates (Ostrander $e t$ al. 1992). The colonies in each plate were transferred to nylon membranes and hybridized with the probes mentioned above. A second clone selection was made by a quimioluminescent method (BCIP/NBT Substrate Kit - ZYMED Laboratories $\left.{ }^{\circledR}\right)$. The positive clones were amplified by PCR using M13 forward and reverse primers flanking the inserts. PCR products with more than 500 bp were sequenced with ABI BigDye Terminators in a 3130x Genetic Analyser (ABI 310) automated sequencer. To exclude contamination hypothesis, each sequence was compared with other sequences at GenBank to verify their homology.

Of the 106 fragments sequenced, it was possible to design 37 primers using AmplifX 1.4 (Jullien 2006) and Primer3 (Rozen \& Skaletsky 2000). An initial PCR was performed to optimize primers activity (available under request). Eight primer pairs resulted in good PCR products, but excessive stuttering only allowed proceeding with four markers (Table 2). Subsequent genotyping was made using fluorescent primers, in an ABI 3730 sequencer, and the program GeneMarker v.194 (Softgenetics ${ }^{\circledR}$ ) for reading fragment sizes.

Further loci characterization, hierarchical analysis of molecular variance (AMOVA) and genetic estimates were calculated using Arlequin 3.11 (Excoffier et al. 2005). The most appropriate mutation model was chosen by performing an alleles' permutation test, with 20000 permutations, implemented in SPAGeDi 1.3a (Hardy \& Vekemans 2002). The presence of null alleles was tested by MICRO-CHECKER (Ooesterhout et al. 2004). Isolation by distance was tested through a Mantel test performed by GenAlEx (Peakall \& Smouse 2006).

\section{Nuclear DNA sequences}

Preferentially we designed primers in mammalian exon conserved regions, so intronic regions could be amplified (Slade et al. 1993), using AmplifX 1.4 (Jullien 2006) and Primer3 (Rozen \& Skaletsky 2000). Primers already published were also tested (Murphy et al. 1999; Baker et al. 2000). It was possible to amplify five different nuclear gene fragments: the seventh 
intron of the beta-fibrinogen gene (FGB), the recombination activating 2 (RAG2) and the betaglobin (HBB) partial genes, and the second introns of the hypoxanthine-guanosine phosphoribosyl transferase (HPRT) and of the proteolipid protein 1 (PLP1) genes, both located in the $\mathrm{X}$ chromosome. To obtain amplicons and sequences for all individuals, different primers were used (Table 2). PCR program consisted of an initial denaturation of $92^{\circ} \mathrm{C} 5 \mathrm{~min}$., followed by 35 cycles of $92^{\circ} \mathrm{C} 45 \mathrm{sec}$., 52 to $62^{\circ} \mathrm{C} 50 \mathrm{sec}$. and $72^{\circ} \mathrm{C} 1.5 \mathrm{~min}$. The amplifications were carried out in $22.5 \mu \mathrm{L}$ of $2.5 \mu \mathrm{L}$ of DNA (about $10 \mathrm{ng}$ ), $1 \mathrm{X}$ buffer, $1 \mathrm{pmol} / \mu \mathrm{L}$ of each primer, $1 \mathrm{mM}$ of dNTPs, $2.2 \mathrm{mM}$ of $\mathrm{MgCl}_{2}$ and $1.5 \mathrm{U}$ of Taq DNA polymerase.

Table 2. Polymerase chain reaction (PCR) and sequencing reaction conditions for the amplification of the newly described nuclear markers within the pygmy (Bradypus pygmaeus), the maned (B. torquatus, only nuclear DNA sequences) and the commom (B. variegatus) sloths.

\begin{tabular}{|c|c|c|c|c|}
\hline & & Primers & $\mathbf{T m}^{\mathbf{a}}$ & $\mathrm{MgCl}_{2}$ \\
\hline \multirow{4}{*}{ 宸 } & Bv248 & $\begin{array}{l}\text { Bv248 F 5'AAGCAAGTTTCAGAACAGG3' } \\
\text { Bv248 R 5'TCATACCTTAGAGAACTGC3' }\end{array}$ & $55^{\circ} \mathrm{C}$ & $1.7 \mathrm{mM}$ \\
\hline & Bv249 & $\begin{array}{l}\text { Bv249 F 5'AGAGGTGACGAGATGATACG3' } \\
\text { Bv249 R 5'GATCAACACTAAGTGCACTC3' }\end{array}$ & $48^{\circ} \mathrm{C}$ & $2.2 \mathrm{mM}$ \\
\hline & Bv176 & $\begin{array}{l}\text { Bv176 F 5'TCCTAAAACCTTTTGTTTCC3' } \\
\text { Bv176 R 5'CTTATTGTCGGTGTTTCTC3' }\end{array}$ & $55^{\circ} \mathrm{C}$ & $2.4 \mathrm{mM}$ \\
\hline & Bv149 & $\begin{array}{c}\text { Bv149 F 5'GTGTCACTGCCCAGATAG3' } \\
\text { Bv149 R 5'TGTGAACTGGAAACACATGG3' }\end{array}$ & $50^{\circ} \mathrm{C}$ & $3.5 \mathrm{mM}$ \\
\hline \multirow{5}{*}{ 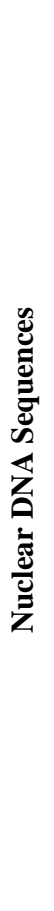 } & FGB & 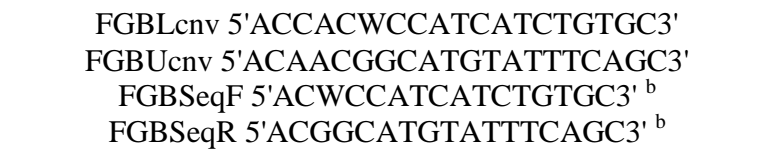 & $52^{\circ} \mathrm{C}$ & $2.2 \mathrm{mM}$ \\
\hline & HBB & $\begin{array}{c}\text { HBF 5'ACTCCCTGGAAGGAAGGGGAGG3' } \\
\text { HBR 5'AAAGCAGAAAGTGGTGCTCAGTG3' } \\
\text { HBBFint 5'GCACTTCAGTGTTCT3' } \\
\text { HBBRint 5'AAGCTTGATCATAGA3' }\end{array}$ & $62^{\circ} \mathrm{C}$ & $2.2 \mathrm{mM}$ \\
\hline & RAG2 $^{c}$ & $\begin{array}{c}\text { RAG2-F1 5'GGCTGGCCCAARAGATCCTG3' } \\
\text { RAG2-F2 5'TTTGTTATTGTTGGTGGCTATCAG3' } \\
\text { RAG2-R1 5'AACYTGYTTATTGTCTCCTGGTATGC3' } \\
\text { RAG2-R2 5'GRAAGGAATTTCTTGGCAGGAGGAGT3' }\end{array}$ & $61^{\circ} \mathrm{C}$ & $2.2 \mathrm{mM}$ \\
\hline & HPRT & $\begin{array}{c}\text { BraHPRTI2FN 5'CTCATGGACTAATTATGGACAGGT3' } \\
\text { BraHPRTI2R 5'TAAAATCTACAGTCATAGGAATGG3' } \\
\text { HPRTSEQFF 5'CTCATGGACTAATTATGG3' b } \\
\text { HPRTSEQR 5'CTTGAGCACACAGAGGGC3' } \\
\text { HPRTSeqTorqF 5'AAAAGGGAAATGAGC3' } \\
\text { HPRTSeqTorqR 5'GGATGCTTTCTCTTAA3' }\end{array}$ & $54^{\circ} \mathrm{C}$ & $2.2 \mathrm{mM}$ \\
\hline & PLP1 $^{c}$ & $\begin{array}{l}\text { PLPF 5'GGCCACTGGATTGTGTTTCT3' } \\
\text { PLPR 5'TAGTCGCCAAAGATCTGCCT3' } \\
\text { PLPSEQF 5'CCACTGGATTGTGTTTCT3' b }\end{array}$ & $61^{\circ} \mathrm{C}$ & $2.2 \mathrm{mM}$ \\
\hline
\end{tabular}

\footnotetext{
${ }^{\text {a }}$ Melting temperature (Tm).

${ }^{\mathrm{b}}$ Sequencing primers.

${ }^{c}$ Primers described by Baker et al. 2000 (RAG2) and Murphy et al. 1999 (PLP1), respectively.
} 
PCR products were purified with ExoSap GE Healthcare kit, following the manufacture's protocol, and sequenced with ABI BigDye Terminators kit in an Applied Biosystems 3130xl Genetic Analyzer or an ABI PRISM 3100 Genetic Analyzer. Both strands were sequenced to improve the accuracy of base calling. Sequences were visually inspected using BioEdit (Hall, 1999) and aligned by Clustal Omega (Sievers et al. 2011). Alignment gaps were treated as the fifth character state. Assignment of HBB coding regions was done by comparison with Bradypus tridactylus data (Opazo et al. 2009; GenBank accession number DQ091214.1).

DnaSP (Librado \& Rozas 2009) was used to infer the haplotipic phases (Stephens \& Donnelly 2000; Stephens et al. 2001) and estimate genetic diversity indices independently for each gene and population. General genetic diversity was averaged over all loci. Pairwise comparisons of the genetic diversities were performed by an one-tailed test, with 1000 permutations and a significance level of $\alpha=0.05$. DnaSP software was also used to test for recombination (Hudson \& Kaplan 1985), and neutrality deviations through calculation of Tajima's D (Kimura 1983; Tajima 1983, 1989). Population growth was tested by $\mathrm{R}_{2}$ statistics, which is the most appropriated test, when sample sizes and/or number of segregating sites are low, and there is some recombination within the data (Ramos-Onsins \& Rozas 2002). Statistical significance was calculated, by a coalescent simulation test, of 1000 replicates, and allowing for free recombination. We also plotted the distribution of observed pair-wise nucleotide site differences (mismatch distribution) and the expected distribution under demographic expansion (Rogers \& Harpending 1992). Time elapsed since the demographic growth event was calculated by estimating $\tau$, and letting $\theta_{1}$ to be infinite (Rogers 1995), in Arlequin 3.11 (Excoffier et al. 2005). Significance levels were obtained by 1000 bootstrap replicates.

Haplotipic networks were obtained by median joining (Bandelt et al. 1999).

\section{Multi loci analysis}

To compare previously published common sloth mtDNA population structure with the present study data, we performed a Bayesian analysis to infer the most likely number of clusters $(\mathrm{K})$ in the total common sloth dataset (microsatellites + nuclear DNA sequences). This was performed in STRUCTURE 2.3.4 program (Pritchard et al. 2000), using a length of burnin period of $10^{5}$ a number of MCMC repeats after burnin equal to $10^{6}$, and 10 replicas for each $\mathrm{K}$. Since the dispersal of individuals is probably not homogenous among populations, we used the Evanno et al. (2005) method to confirm the most probable number of clusters (Earl \& von Holdt 2012). 


\section{Results}

\section{Markers characterization}

Microsatellites

Despite all efforts, and several attempts, only four polymorphic microsatellites were described for the AF common sloth. These were cross-tested in the pygmy and maned sloths, but only amplified in the first one. Microsatellites characterization is depicted in Table 3.

MICRO-CHECKER did not detected null alleles in the pygmy sloth dataset. On the other hand, all loci, except Bv149, had null alleles within the common sloth dataset. However, when accounting for the presence of structure, i.e. assigning samples according to their sampling locality, only Bv249 had to be excluded from further analyses due to null alleles' detection.

Regarding the mutation model that best fitted microsatellites' data, for the pygmy sloth dataset, genetic drift effect was preponderant, since all permutation tests were not significant. As for the common sloth, loci $\operatorname{Bv} 248(p=0.0138)$ and $\operatorname{Bv} 149(p=0.0045)$ had a significant effect of stepwise mutations on population differentiation, nevertheless the average $p$ value was not significant $(p=0.0890)$. Consequently, for both species, allele identity based statistics (e. g. Fst) should better estimate populations' differentiation than allele size based statistics (e. g. Rst; Hardy \& Vekemans 2002).

Table 3. Microsatellites' diversity for the pygmy sloth (Bradypus pygmaeus) and the common sloth ( $B$. variegatus) populations. Mean values and respective standard deviations (s.d.) considered only polymorphic loci. AF - Atlantic forest; AFCS - central/southern AF; AFNE - northeastern AF; AMZEast - eastern Amazonia; AMZWest - western Amazonia.

\begin{tabular}{|c|c|c|c|c|c|c|c|}
\hline & \multirow{2}{*}{$\begin{array}{l}\text { Pygmy } \\
\text { sloth }\end{array}$} & \multicolumn{6}{|c|}{ Common sloth } \\
\hline & & Total dataset & $\mathbf{A F}$ & AFCS & AFNE & AMZEast & AMZWest \\
\hline MNA (s.d.) ${ }^{a}$ & $\begin{array}{c}2.00 \\
(1.00)\end{array}$ & $\begin{array}{c}9.00 \\
(4.36)\end{array}$ & $\begin{array}{c}4.333 \\
(1.528)\end{array}$ & $\begin{array}{c}2.333 \\
(0.577)\end{array}$ & $\begin{array}{c}4.333 \\
(1.528)\end{array}$ & $\begin{array}{c}4.333 \\
(4.163)\end{array}$ & $\begin{array}{c}4.667 \\
(0.577)\end{array}$ \\
\hline Average $\mathrm{He}$ (s.d.) ${ }^{b}$ & $\begin{array}{c}0.320 \\
(0.304)\end{array}$ & $\begin{array}{c}0.405 \\
(0.162)\end{array}$ & $\begin{array}{c}0.262 \\
(0.100)\end{array}$ & $\begin{array}{c}0.173 \\
(0.143)\end{array}$ & $\begin{array}{c}0.387 \\
(0.135)\end{array}$ & $\begin{array}{c}0.383 \\
(0.470)\end{array}$ & $\begin{array}{c}0.815 \\
(0.0340)\end{array}$ \\
\hline Fis (p-value) ${ }^{\mathrm{c}}$ & $\begin{array}{c}0.433 \\
(0.0635)\end{array}$ & $\begin{array}{c}0.475 \\
(0.000)\end{array}$ & $\begin{array}{l}0.0632 \\
(0.220)\end{array}$ & $\begin{array}{l}-0.108 \\
(0.890)\end{array}$ & $\begin{array}{c}0.137 \\
(0.106)\end{array}$ & $\begin{array}{l}0.0233 \\
(0.581)\end{array}$ & $\begin{array}{c}0.111 \\
(0.304)\end{array}$ \\
\hline
\end{tabular}

${ }^{\mathrm{a}}$ Mean number of alleles (MNA).

${ }^{\mathrm{b}}$ Expected heterozygosity (He).

${ }^{\mathrm{c}}$ Inbreeding coeficient (Fis).

\section{Nuclear DNA sequences}

The five nuclear genes analyzed resulted in successful amplifications for all the sloth species. A total of 4226, 3570, and 3329 bp were analyzed for the pygmy, maned and common sloths, respectively. The number of polymorphic sites varied between zero (HPRT and PLP1) and one (FGB, HBB and RAG2) for the pygmy sloth, one (FGB and PLP1) to 11 (HBB and HPRT) for the maned sloth, and four (PLP1) and 23 (HBB) for the common sloth. Within the 
AF common sloth, these numbers were similar to those found for the pygmy sloth. The number of haplotypes described for each dataset is presented in (Table 4).

Estimates of nucleotide $(\pi)$ and gene $(H d)$ diversities varied among loci and species (Table 4). Pygmy sloth estimates were significantly lower than maned sloth ones $(p \leq 0.003)$. Common sloth data was considerably affected by departure from neutrality (FGB and HPRT) and recombination (HBB, HPRT and RAG2). The number of these events decreased when accounting for structure in the dataset.

\section{Common sloth population structure}

Bayesian inferences of the number of populations highlighted the differentiation between $\mathrm{AF}$ and AMZ. Either considering admixture or not, the most likely number of clusters in the total dataset was two, distinguishing AF samples from the AMZ ones, and grouping Ceará (CE) within the AMZ cluster (Fig. 1 and $2 \mathrm{~K}=2$ ). Nevertheless other clustering patterns were also examined. The second split ( $\mathrm{K}=3$ ) separated the western (Geographic region 8, GR8, and Acre, AC) from the eastern AMZ (GR5 and CE). The AF GR3, together with Pernambuco (PE) and Paraíba (PB) localities were separated from the other AF populations (GR2 and GR1) at K=4 (Fig. 1 and Fig. $2 \mathrm{~K}=4$ ). The rate of change of the log probability of the data for simulations considering $\mathrm{K}=4$ was the second highest in both Bayesian models considered. Within the $\mathrm{AF}$ dataset, the most likely structure separated GR3/PE/PB from the other sampled AF GRs (Fig. 1 and $2 \mathrm{~K}=2 \mathrm{AF}$ ).

We detected slight but significant isolation by distance (IBD) for the total common sloth dataset $\left(\mathrm{R}^{2}=0.3212 ; p=0.000\right)$, and within $\mathrm{AF}\left(\mathrm{R}^{2}=0.0481 ; p=0.001\right)$.

AMOVA considering four clusters supported this genetic structure, since the percentage of genetic variation among populations $(32.71 \%)$ was higher than among individuals within populations $(2.08 \%)$. Also for $\mathrm{K}=4$, the lowest $F s t$ values obtained with the nuclear DNA sequences corresponded to the comparison between AF populations (GR3/PE/PB vs. GR1/GR2), but only two in five (PLP1 and FGB) gave non-significant results, and all other were not only significant, but also higher than 0.20. The resulting mean $F s t$ value between GR3/PE/PB and GR1/GR2 was of 0.221 (Table 5). Neighbor-joining trees provided additional confirmation for four clusters (Fig. 3).

Thus, further analysis considered as distinct common sloth populations the groups of samples from the western $(\mathrm{GR} 8 / \mathrm{AC}=\mathrm{AMZWest})$ and eastern Amazonia $(\mathrm{GR} 5 / \mathrm{CE}=$ AMZEast), and from the northeast $(\mathrm{GR} 3 / \mathrm{PE} / \mathrm{PB}=\mathrm{AFNE})$ and the center and south of the AF $($ GR1/GR2 = AFCS; Figs. 1, 3) . 
Table 4. Number of haplotypes (Hap), nucleotide $(\pi)$ and gene $(H d)$ diversities, and the results for the population expansion test $\left(\mathrm{R}_{2}\right)$ for all the nuclear DNA sequences analyzed. Mean values for the diversity estimates and respective standard deviations (s.d.) were calculated considering only polymorphic and non-recombining loci. AF - Atlantic forest; AFCS - central/southern AF; AFNE - northeastern AF; AMZEast - eastern Amazonia; AMZWest - western Amazonia.

\begin{tabular}{|c|c|c|c|c|c|c|c|c|c|}
\hline & & & & & & Comm & n sloth & & \\
\hline & ene & Pygmy sloth & Maned sloth & $\begin{array}{c}\text { Total } \\
\text { dataset }\end{array}$ & $\mathbf{A F}$ & AFCS & AFNE & AMZEast & AMZWest \\
\hline & Hap & 2 & 2 & 12 & 3 & 3 & 1 & 4 & 5 \\
\hline FGB & $\pi$ (s.d.) & $0.63 \times 10^{-3}$ & $0.81 \times 10^{-3}$ & $1.49 \times 10^{-3}$ & $0.36 \times 10^{-3}$ & $0.490 \times 10^{-3}$ & 0 & $1.35 \times 10^{-3}$ & $5.35 \times 10^{-3}$ \\
\hline & & $(0.00012)$ & & & & $(0.00013)$ & & $(0.00028)$ & $(0.00086)$ \\
\hline & $H d$ (s.d.) & $\begin{array}{l}0.442 \\
(0.087)\end{array}$ & 0.522 & 0.458 & 0.205 & 0.280 & 0 & 0.659 & 0.889 \\
\hline & & $\begin{array}{l}(0.087) \\
0.2210\end{array}$ & $\begin{array}{l}(0.030) \\
0.2609\end{array}$ & (0.060) & & $\begin{array}{l}(0.0 / 0) \\
0.0910\end{array}$ & & $\begin{array}{c}(0.090) \\
0.1428\end{array}$ & $\begin{array}{l}(0.0 / 5) \\
0.1393\end{array}$ \\
\hline & $\mathbf{R}_{\mathbf{2}}$ & $(0.7900)$ & $(1.0000)$ & & & $(0.1215)$ & 0 & $(0.2820)$ & $(0.3700)$ \\
\hline & Hap & 2 & 14 & 17 & 7 & 5 & 4 & 7 & 4 \\
\hline & $\pi(\mathbf{s}, \mathbf{d})$ & $0.10 \times 10^{-3}$ & a & $\mathrm{a}$ & $3.20 \times 10^{-3}$ & $1.93 \times 10^{-3}$ & $4.52 \times 10^{-3}$ & $\mathrm{a}$ & $6.31 \times 10^{-3}$ \\
\hline HBB & $\pi$ (s.a.) & $(0.00009)$ & & & $(0.00052)$ & $(0.00064)$ & $(0.00055)$ & & $(0.00106)$ \\
\hline & $H d($ s.d. $)$ & 0.111 & $\mathrm{a}$ & $\mathrm{a}$ & 0.425 & 0.284 & 0.569 & $\mathrm{a}$ & 0.867 \\
\hline & $\operatorname{ma}$ (s.u.) & $(0.096)$ & & & $(0.065)$ & $(0.083)$ & $(0.071)$ & & $(0.129)$ \\
\hline & R. & 0.2291 & 0.1027 & & & 0.0933 & 0.1359 & 0.2226 & 0.2440 \\
\hline & $\mathbf{R}_{2}$ & $(0.4590)$ & $(0.1700)$ & & & $(0.2880)$ & $(0.9570)$ & $(0.9980)$ & $(0.9780)$ \\
\hline & Hap & 2 & 4 & 17 & 8 & 6 & 2 & 7 & 3 \\
\hline & $\pi$ (s.d.) & $0.18 \times 10^{-3}$ & $1.40 \times 10^{-3}$ & $\mathrm{a}$ & a & a & $0.66 \times 10^{-3}$ & a & $4.54 \times 10^{-3}$ \\
\hline RAG2 & & $(0.00016)$ & $(0.00070)$ & & & & $(0.00014)$ & & $(0.00160)$ \\
\hline & $H d($ s.d.) & 0.125 & 0.314 & $\mathrm{a}$ & a & a & 0.458 & a & 0.833 \\
\hline & & $(0.106)$ & $(0.138)$ & & & & $(0.095)$ & & $(0.222)$ \\
\hline & $\mathbf{R}_{2}$ & 0.2421 & 0.0888 & & & 0.1508 & 0.2292 & 0.1496 & 0.2788 \\
\hline & $\mathbf{K}_{2}$ & $(0.5090)$ & $(0.0120)$ & & & $(0.7350)$ & $(0.4710)$ & $(0.5640)$ & $(0.9820)$ \\
\hline & Hap & 1 & 6 & 13 & 5 & 2 & 4 & 4 & 4 \\
\hline & & & $3.63 \times 10^{-3}$ & $a$ & $0.63 \times 10^{-3}$ & $0.190 \times 10^{-3}$ & $1.02 \times 10^{-3}$ & $1.45 \times 10^{-3}$ & $2.89 \times 10^{-3}$ \\
\hline HPRT & $\pi$ (s.d.) & 0 & $(0.00094)$ & $a^{a}$ & $(0.00016)$ & $(0.00018)$ & $(0.00018)$ & $(0.00044)$ & $(0.00099)$ \\
\hline & & & 0.800 & $\mathrm{a}$ & 0.372 & 0.067 & 0.616 & 0.694 & 0.900 \\
\hline & Hd(s.d.) & 0 & (0.077) & & (0.078) & $(0.061)$ & (0.067) & $(0.147)$ & $(0.161)$ \\
\hline & & & 0.1302 & & & 0.1795 & 0.1307 & 0.1667 & 0.2191 \\
\hline & $\mathbf{R}_{2}$ & 0 & $(0.3570)$ & & & $(0.8110)$ & $(0.3390)$ & $(0.3690)$ & $(0.8030)$ \\
\hline & Hap & 1 & 2 & 5 & 1 & 1 & 1 & 1 & 4 \\
\hline PLP1 & $\pi$ (s.d.) & 0 & $\begin{array}{l}0.74 \times 10^{-3} \\
(0.00007)\end{array}$ & $\begin{array}{l}0.47 \times 10^{-3} \\
(0.00012)\end{array}$ & 0 & 0 & 0 & 0 & $\begin{array}{l}2.05 \times 10^{-3} \\
(0.00061)\end{array}$ \\
\hline & $H d($ s.d.) & 0 & 0.515 & 0.302 & 0 & 0 & 0 & 0 & 0.900 \\
\hline & & & $(0.052)$ & $(0.064)$ & & & & & $(0.161)$ \\
\hline & $\mathbf{R}_{2}$ & 0 & $\begin{array}{c}0.2563 \\
(0.9310)\end{array}$ & & & 0 & 0 & 0 & $\begin{array}{c}0.1871 \\
(0.2670)\end{array}$ \\
\hline & Hap & 1.6 & 5.6 & 12.8 & 4.8 & 3.4 & 2.4 & 4.6 & 4.0 \\
\hline & $\pi\left(\mathrm{sd}^{\mathrm{T}}\right.$ & $0.30 \times 10^{-3}$ & $1.64 \times 10^{-3}$ & $0.98 \times 10^{-3}$ & $1.40 \times 10^{-3}$ & $0.870 \times 10^{-3}$ & $2.07 \times 10^{-3}$ & $1.40 \times 10^{-3}$ & $4.23 \times 10^{-3}$ \\
\hline Mean & $\pi($ S.d. & $(0.000286)$ & $(0.00136)$ & $(0.00072)$ & $(0.00157)$ & $(0.00093)$ & $(0.00213)$ & $(0.000071)$ & $(0.0017)$ \\
\hline & & 0.226 & 0.538 & 0.610 & 0.334 & 0.210 & 0.548 & 0.677 & 0.878 \\
\hline & Hd $(\mathrm{s.d}$ & $(0.187)$ & $(0.200)$ & $(0.3513)$ & $(0.115)$ & $(0.124)$ & $(0.081)$ & $(0.025)$ & $(0.028)$ \\
\hline
\end{tabular}

${ }^{\mathrm{a}}$ One or more events of recombination were detected for this gene within this population. 

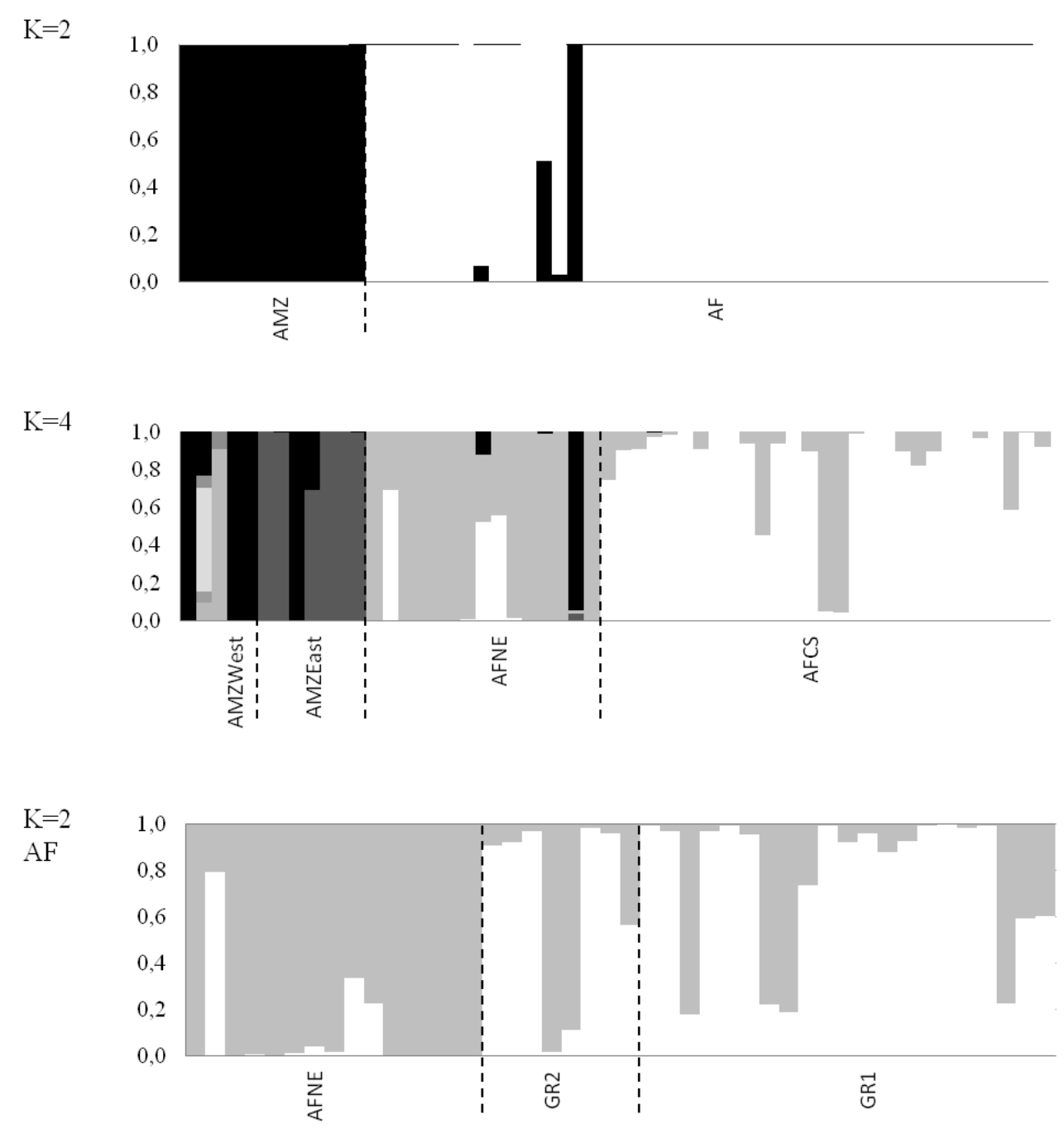

Figure 2. Common sloth (Bradypus variegatus) population structure analyses. STRUCTURE software diagrams for the most likely number of clusters within the total dataset $(\mathrm{K}=2)$, and another less probable but corresponding also to $\Delta \mathrm{K}$ peak $(\mathrm{K}=4)$. Atlantic forest dataset was found to be most likely structured in two clusters $(\mathrm{K}=2 \mathrm{AF})$ Graphics correspond to models considering no admixture, but admixture models led to similar results. AMZ - Amazonia; AF - Atlantic forest; AMZWest - western AMZ groups geographic region (GR) 8 to Acre (AC); AMZEast - eastern AMZ encompasses GR5 and Ceará (CE); AFNE - northeastern AF clusters GR3, Pernambuco (PE) and Paraíba (PB); and AFCS - central and southern AF groups GR2 with GR1.

\section{Population genetic analyses of threatened and non-threatened species}

Genetic diversity indices for the four sampled common sloth populations are summarized in Tables 3 (microsatellites) and 4 (nuclear DNA sequences).

Microsatellites mean number of alleles was significantly lower for the AF population as a whole $(p=0.002)$ when compared to the common sloth total dataset. The pygmy sloth and the 
AFCS populations had the lowest genetic diversity indices, comparing to the AMZWest and AFNE common sloth populations $(0.000 \leq p \leq 0.022)$. The other population differences among genetic diversity indices were not statistically significant. The single statistically significant inbreeding coefficient has no biological meaning, since regards the total common sloth dataset (Table 3). The highest Fis value was detected in the pygmy sloth, and conversely AFCS has signs of less inbreeding than expected.

At the nuclear DNA sequences, AMZ common sloth populations had significantly higher genetic diversity than AFCS, AFNE, pygmy sloth and maned sloth populations $(p \leq 0.05)$. Mean AFCS and AF gene diversity $(H d)$ were also significantly smaller than the maned sloth population ( $p \leq 0.007)$, and similar to the pygmy sloth genetic diversity estimates.

$\mathrm{R}_{2}$ statistics did not support population expansions ( $p>0.05$; Table 4$)$. The distributions of observed pairwise nucleotide site differences (mismatch distribution) coincided with the respective expected distributions under demographic expansion for all populations, except common sloth AMZ ones (Fig. 4). The same trend is evidenced by the star-like form of the haplotipic networks, with a high number of singletons within populations (Fig. 3). However, time estimates for the expansion events were difficult to obtain, since only broad estimates could be inferred, with little consistency among them (Table S2).

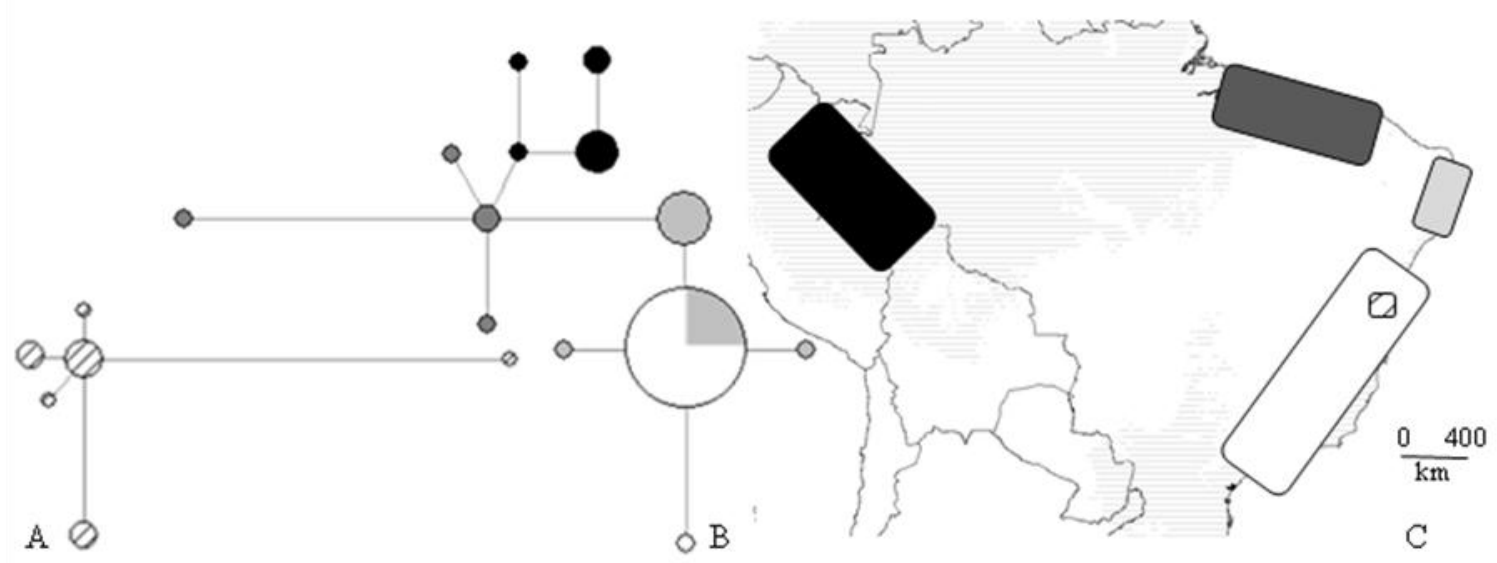

Figure 3. Median-joining networks generated for the second intron of the hypoxanthine-guanosine phosphoribosyl transferase (HPRT) for A) the maned sloth (Bradypus torquatus) and B) the common sloth (B. variegatus). The area of each circle indicates haplotype frequency in each dataset, and the connections' lengths are proportional to the number of mutations found between haplotypes. These networks are representative of the genetic variation found within the other studied species' genes. Number of haplotypes for the the pygmy sloth (B. pygmaeus) varied between one or two, and so no network was generated. C) Haplotypes locations are depicted in the map and correspond respectively to Bahia's maned sloth population (stripped), and AFCS (white), AFNE (light grey), AMZEast (dark grey) and AMZWest (black) common sloth populations. 
Table 5. Pairwise differentiation indices (Fst) among common sloth populations (Bradypus variegatus) estimated with nuclear DNA sequences and microsatellites $(\mu)$. Respective p-values are informed between brackets. Seqs. tables $F s t$ arithmetic means among all nuclear DNA sequences, and respective standard deviations. AFCS - central/southern Atlantic forest; AFNE - northeastern Atlantic forest; AMZEast eastern Amazonia; AMZWest - western Amazonia.

AMZWest AMZEast AFNE

\begin{tabular}{|c|c|c|c|}
\hline PLP1 & & & \\
\hline AMZEast & $\begin{array}{c}0.721 \\
(0.0062)\end{array}$ & & \\
\hline AFNE & $\begin{array}{c}0.810 \\
(0.0000)\end{array}$ & $1.00(0.0000)$ & \\
\hline AFCS & $\begin{array}{c}0.884 \\
(0.0000) \\
\end{array}$ & $1.00(0.0000)$ & $\begin{array}{c}0.000 \\
(0.9999) \\
\end{array}$ \\
\hline \multicolumn{4}{|l|}{ HPRT } \\
\hline AMZEast & $\begin{array}{c}0.554 \\
(0.0004)\end{array}$ & & \\
\hline AFNE & $\begin{array}{c}0.725 \\
(0.0000)\end{array}$ & $\begin{array}{c}0.833 \\
(0.0000)\end{array}$ & \\
\hline AFCS & $\begin{array}{c}0.898 \\
(0.0000) \\
\end{array}$ & $\begin{array}{c}0.935 \\
(0.0000) \\
\end{array}$ & $\begin{array}{c}0.297 \\
(0.0003) \\
\end{array}$ \\
\hline \multicolumn{4}{|l|}{ HBB } \\
\hline AMZEast & $\begin{array}{c}0.109 \\
(0.0172)\end{array}$ & & \\
\hline AFNE & $\begin{array}{c}0.291 \\
(0.0031)\end{array}$ & $\begin{array}{c}0.215 \\
(0.0024)\end{array}$ & \\
\hline AFCS & $\begin{array}{c}0.448 \\
(0.0001) \\
\end{array}$ & $\begin{array}{c}0.349 \\
(0.0000) \\
\end{array}$ & $\begin{array}{c}0.110 \\
(0.0168)\end{array}$ \\
\hline \multicolumn{4}{|l|}{$R A G 2$} \\
\hline AMZEast & $\begin{array}{c}0.253 \\
(0.0191)\end{array}$ & & \\
\hline AFNE & $\begin{array}{c}0.363 \\
(0.0186)\end{array}$ & $\begin{array}{c}0.335 \\
(0.0001)\end{array}$ & \\
\hline AFCS & $\begin{array}{c}0.585 \\
(0.0000) \\
\end{array}$ & $\begin{array}{c}0.556 \\
(0.0000) \\
\end{array}$ & $\begin{array}{c}0.631 \\
(0.0000) \\
\end{array}$ \\
\hline \multicolumn{4}{|l|}{$F G B$} \\
\hline AMZEast & $\begin{array}{c}0.234 \\
(0.0021)\end{array}$ & & \\
\hline AFNE & $\begin{array}{c}0.799 \\
(0.0000)\end{array}$ & $\begin{array}{c}0.655 \\
(0.0000)\end{array}$ & \\
\hline AFCS & $\begin{array}{c}0.837 \\
(0.0000\end{array}$ & $\begin{array}{c}0.686 \\
(0.0000)\end{array}$ & $\begin{array}{c}0.0683 \\
(0.0926)\end{array}$ \\
\hline
\end{tabular}

AMZWest AMZEast AFNE

\begin{tabular}{|c|c|c|c|}
\hline$\mu$ & & & \\
\hline AMZEast & $\begin{array}{c}0.215 \\
(0.0006)\end{array}$ & & \\
\hline AFNE & $\begin{array}{c}0.320 \\
(0.0000)\end{array}$ & $\begin{array}{c}0.384 \\
(0.0000)\end{array}$ & \\
\hline AFCS & $\begin{array}{c}0.570 \\
(0.0000) \\
\end{array}$ & $\begin{array}{c}0.611 \\
(0.0000) \\
\end{array}$ & $\begin{array}{c}0.0697 \\
(0.0005) \\
\end{array}$ \\
\hline \multicolumn{4}{|l|}{ Seqs. } \\
\hline AMZEast & $0.374[0.254]$ & & \\
\hline AFNE & $0.597[0.250]$ & $0.607[0.330]$ & \\
\hline AFCS & $0.730[0.202]$ & $0.705[0.269]$ & $\begin{array}{c}0.221 \\
{[0.254]}\end{array}$ \\
\hline
\end{tabular}

\section{Discussion}

Currently, the AF is isolated from all the other Neotropical rain-forests by a savannah-like corridor in central Brazil (Cole, 1960). Ecological niche-modeling indicates that the current absence of forest in this region is inappropriate to the common sloth occurrence (Phillips et al. 2006). Previous mtDNA analyses showed a genetic differentiation between AF and AMZ common sloth populations (Moraes-Barros et al. 2011). Our evaluation of the species nuclear genetic diversity corroborates this genetic differentiation. Slow evolving molecular markers had private alleles within the AF, indicating ancient distinct evolutionary paths of both populations. 
Figure 4. Plots of the distribution of observed pairwise nucleotide site differences (mismatch distribution) and the expected distributions under demographic expansion for A) the maned sloth (Bradypus torquatus), B) pygmy sloth (B. pygmaeus) and C) AFNE, D) AFCS, E) AMZEast and F) AMZWest common sloth (B. variegatus) populations.

A)
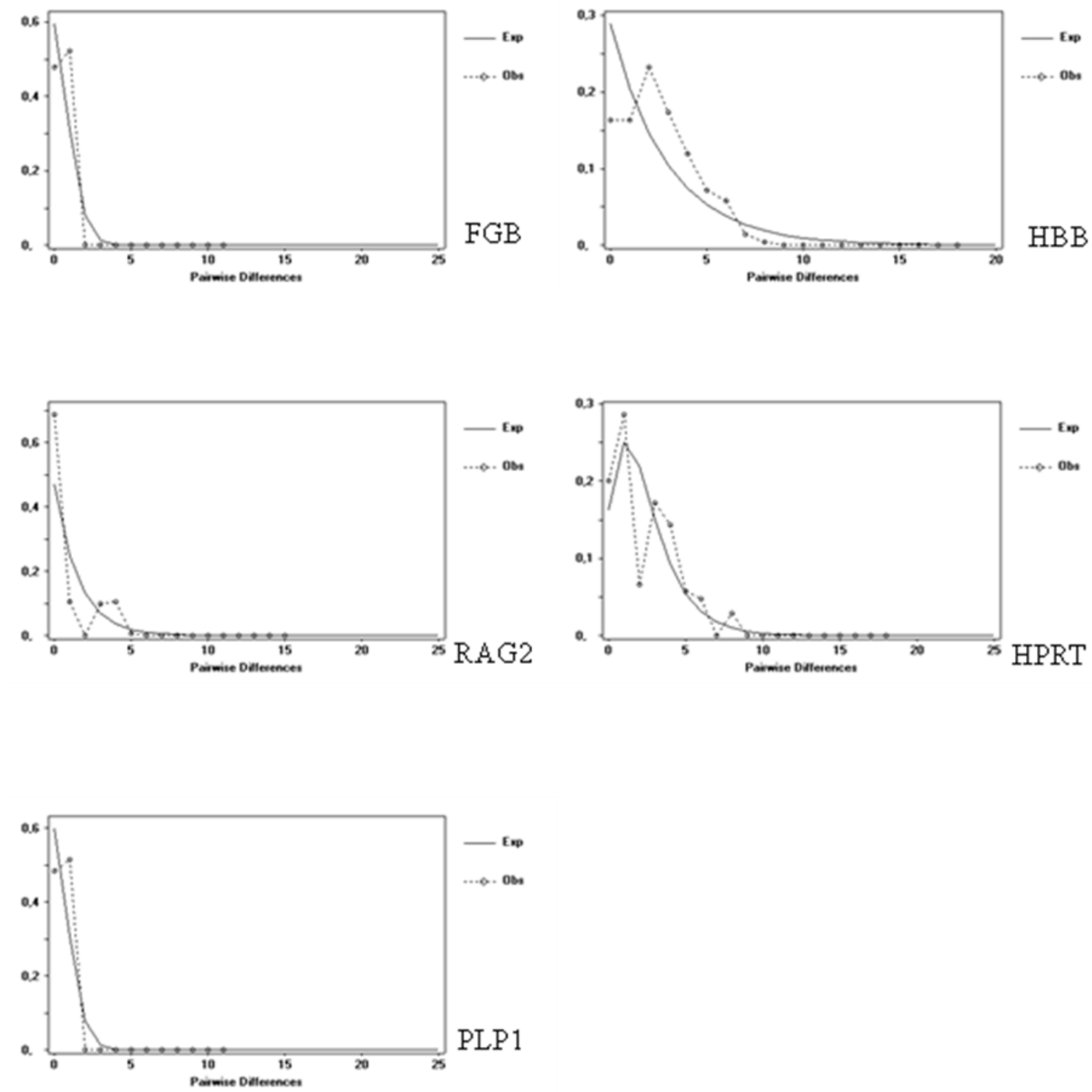
B)
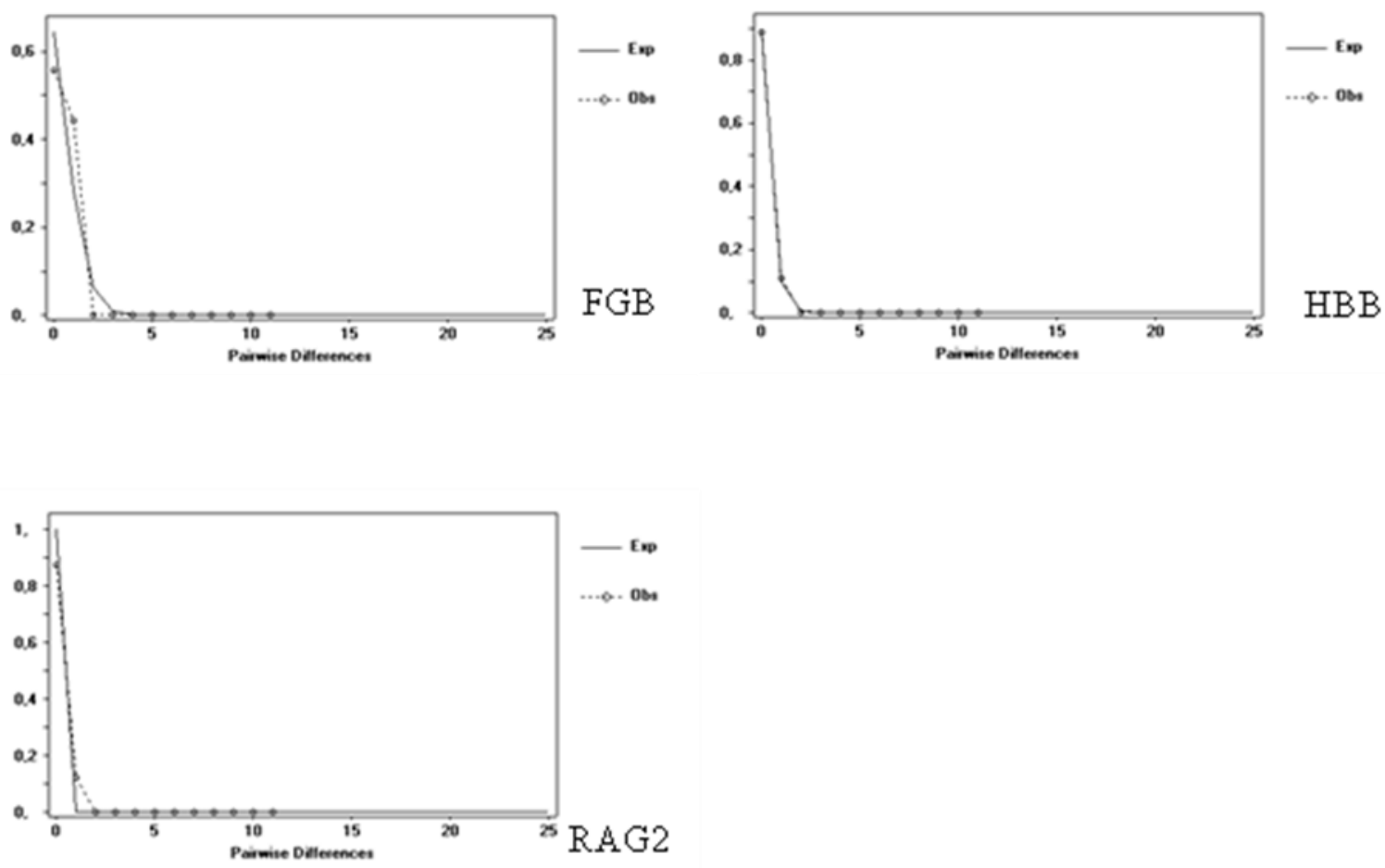

C)
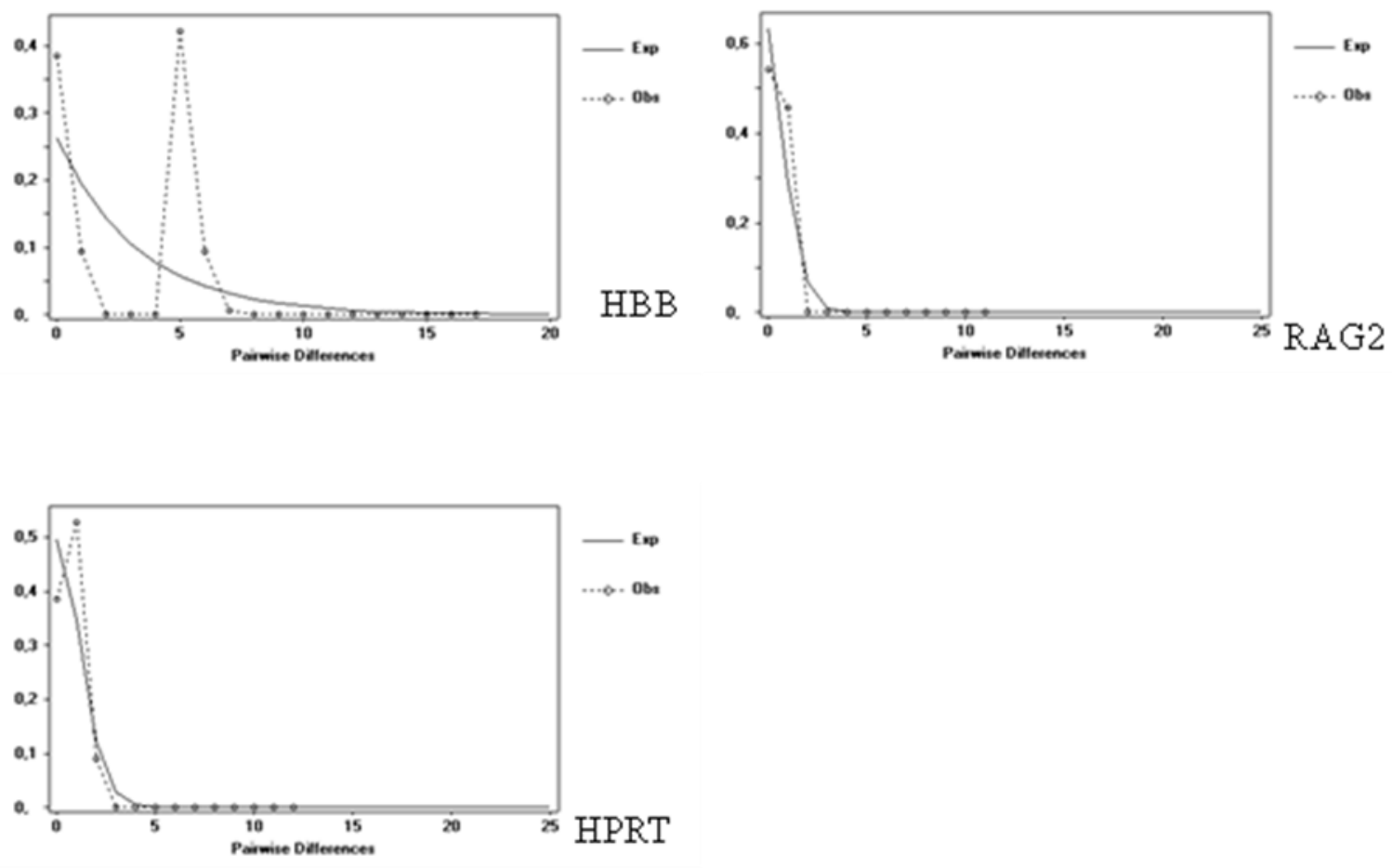
D)
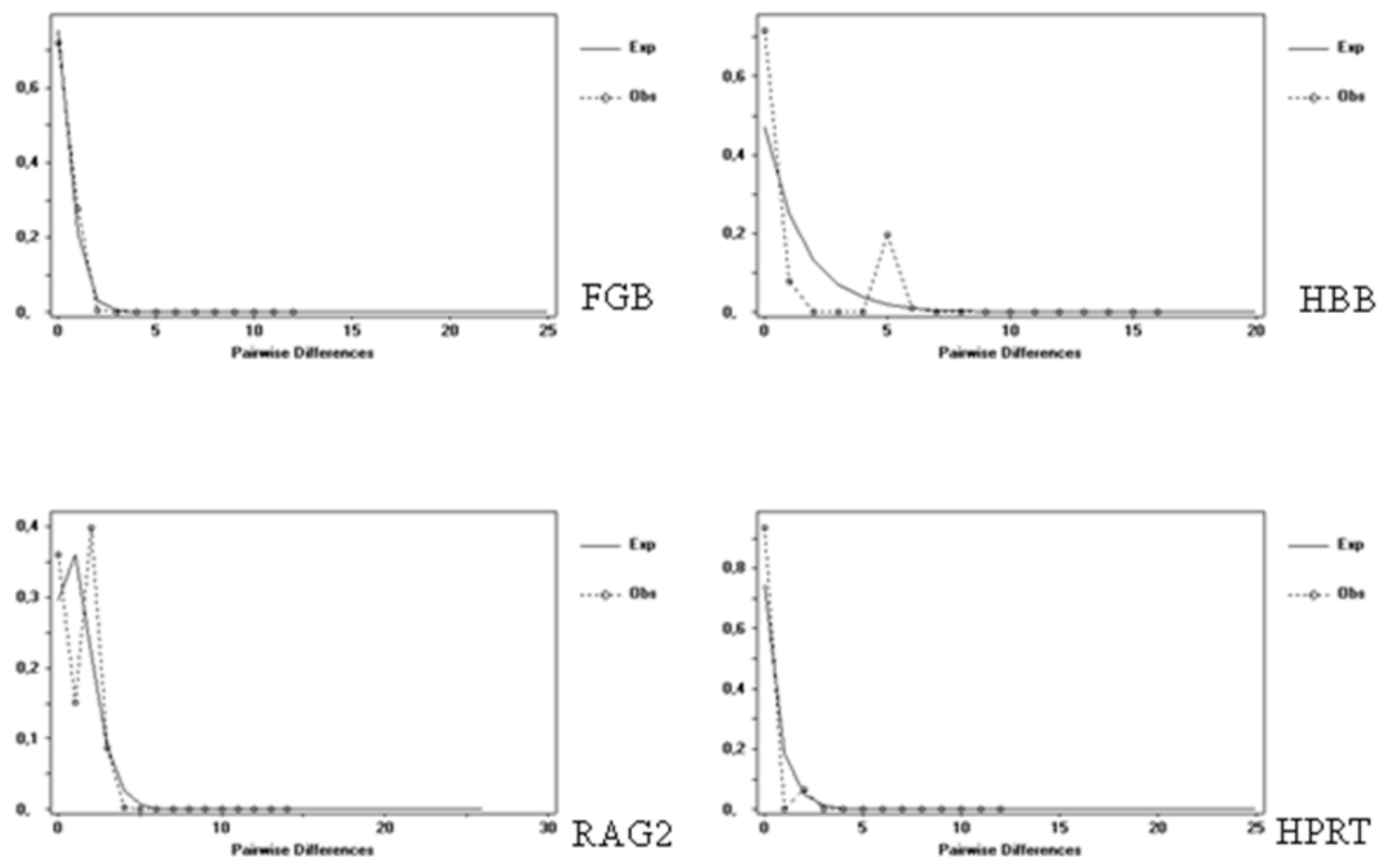

E)
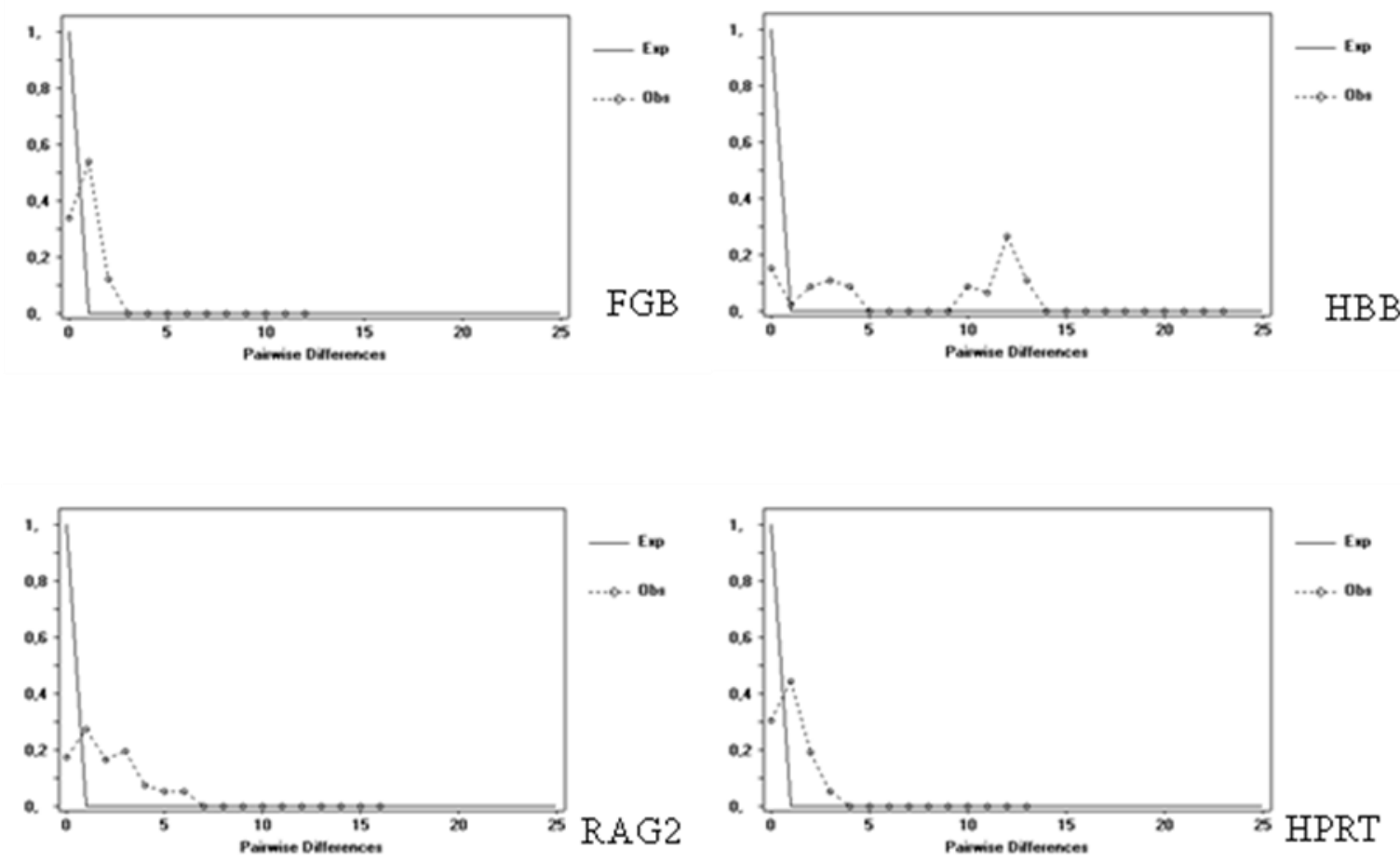
F)
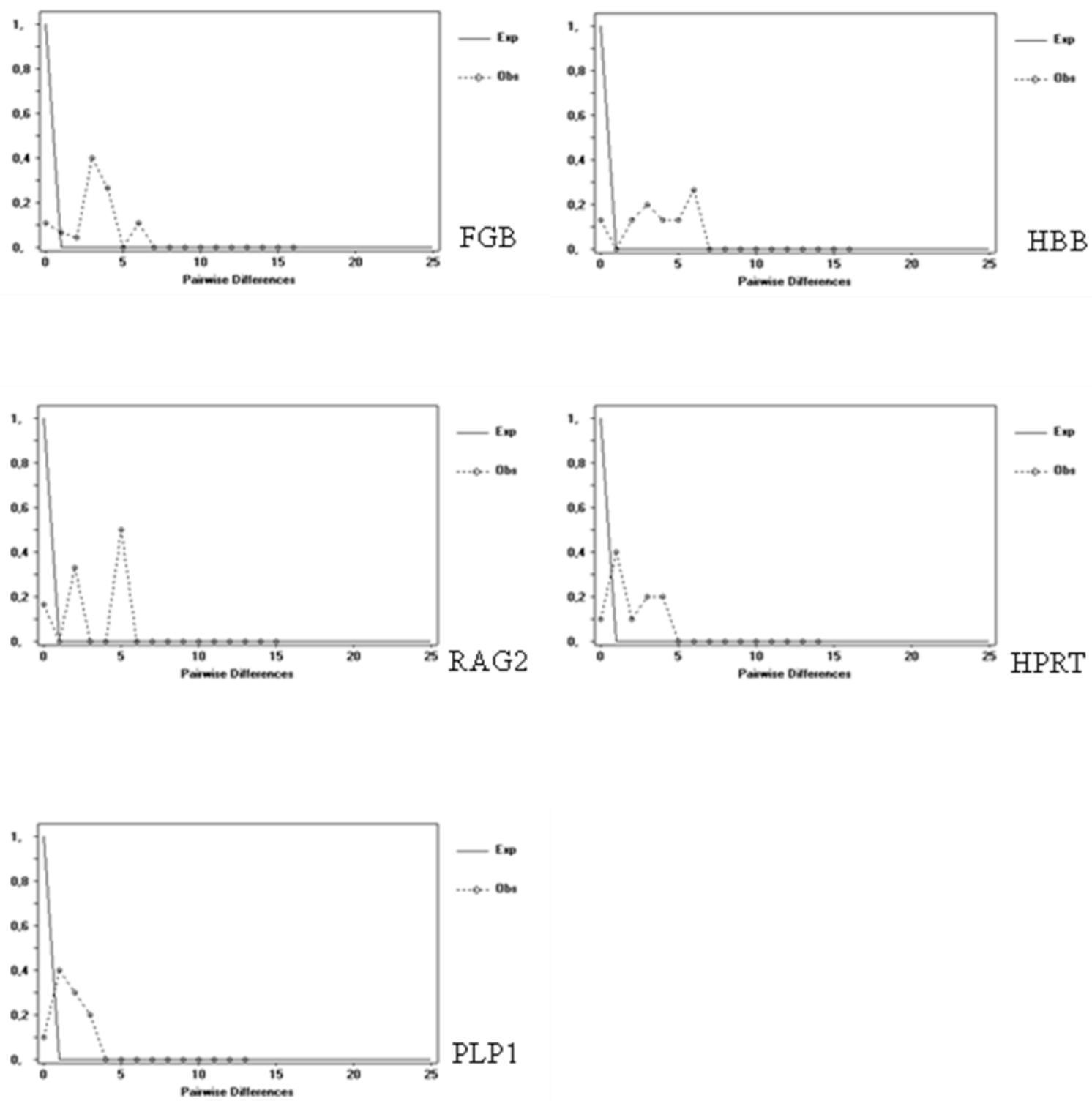

The different genetic diversity levels estimated also strength the AF common sloth populations' uniqueness. The AMZ common sloth populations were characterized by higher genetic diversity indices, particularly in AMZWest. Although this region is not our focal study area, similar indices and higher genetic diversity within the west were reported for other terrestrial mammal species too (Silva \& Patton 1998; Ruiz-Garcia et al. 2006, 2007; Lavergne et al. 2010; Thoisy et al. 2010). They were linked to regional historical factors (e.g. Hoorn et al. 2010), and to species' origin (Lavergne et al. 2010; Alfaro et al. 2011). Further sampling is needed before extrapolating these evidences to the common sloth.

Within the AF, Moraes-Barros et al. (2007) suggested the existence of three common sloth management units (MUs), through the analysis of mtDNA variability. Yet, only GR2 
corresponded to an independent MU. Neither the southern (GR1) nor the northern MUs (GR3) were differentiated from AMZ (GR5 and GR4, respectively). Our Bayesian inferences suggested AF as a panmitic population, or divided in two populations. Differences between nuclear and mtDNA markers in detecting the true population structure are expected, given the higher effective population size of nuclear DNA sequences, and their average lower mutation rate, which together slowdown the genetic drift effects, compared to mtDNA markers (reviewed by Hare 2001). Male mediated gene flow can also dilute the effects of the matrilineal gene flow within nuclear markers (Nyakaana \& Arctander 1999). Indeed, our population differentiation comparisons using X-linked loci (PLP1 and HPRT) gave the highest differentiation indices among the nuclear molecular markers. This result may indicate a pattern of female philopatry for the common sloth. The same pattern was already suggested to explain the geographic structure detected in previous studies with the maned sloth (Lara-Ruiz et al. 2008). The isolation by distance detected could have limited the accuracy in distinguishing the natural common sloth population structure (Pritchard et al. 2010). We should not also exclude the hypothesis of this pattern (two AF populations) be a result of a low number of analyzed microsatellites. However, support for the AF geographical structure can be drawn from our AMOVA results and the high levels of genetic differentiation between the AFNE and AFCS. Our data solve mtDNA geographical ambiguities (Moraes-Barros et al. 2007), and separates GR1 from GR5. Also we increase the range of GR3 grouping not only localities within Alagoas (AL), but also within PE and PB federal states (Fig. 1). The low vagility of sloths (Sunquist \& Montgomery 1973; Montgomery \& Sunquist 1975), and the current AF severe fragmentation (Conservation International do Brasil et al. 2000; INPE \& Fundação SOS da Mata Atlântica 2011), also support a possible contemporary population substructure within the AF common sloth population.

Howsoever, either considering AF common sloth as one panmitic population, or structured in two populations, its genetic diversity levels are alarming, and quite lower than the species' average. In the first scenario, the AF common sloth genetic diversity indices are reduced to about a half of the overall species diversity. These levels were only comparable to the populations of the threatened species analyzed, the maned and the pygmy sloths. Considering two AF populations, the northeastern common sloth population (AFNE) present levels of genetic diversity similar to the species' AMZ population, but the AF central/southern population (AFCS) had the lowest genetic diversity values of all subsets, even lower than other mammalian threatened species (e.g. Garcia et al. 2005; Razafindrakoto et al. 2008; Neuwald et al. 2010; Zschokke et al. 2011), including the Bahia's maned sloth and the pygmy sloth populations herein analyzed. Unexpectedly, we could only describe four polymorphic microsatellite markers. We focused our search in the AFCS population to assure we would have polymorphic markers for analyzing this population, because this had the lowest mtDNA variability (Moraes- 
Barros et al. 2006). Also, we have used a methodology that has originated up to 20 polymorphic markers for other mammalian species (e.g. Garcia et al. 2005; Razafindrakoto et al. 2008; Røed et al. 2011). Thus, we conclude that the lack of polymorphic microsatellite markers further expresses the genetic depauperation of the AFCS population.

At the same time as our work was being developed, Moss et al. (2012) described 18 polymorphic markers from a Costa Rican common sloth population. Our attempts to amplify our markers in samples from this population did not succeeded, and led us to conclude that Moss's et al. (2012) microsatellites would not be successfully cross-amplified in AF common sloth samples. However, future studies should confirm the utility of these Costa Rican molecular markers in the other common sloth populations.

The low levels of genetic diversity found within AFCS population are not reflected by inbreeding signs, but are similar to populations that have suffered drastic population bottlenecks and founder effects (Olivieri et al. 2008; Zschokke et al. 2011; Sonsthagen et al. 2012). However, as far as we know, the species is abundant in the region, and we detected some signs of a population expansion in the markers with slower mutation rate. Probably, stronger signals of expansion and precise time estimates were hindered by the low genetic variability found, and by the stochasticity inherent to the evolution of the molecular markers itself. Thus, we refrain from drawing extensive conclusions from these estimates.

Other slight signs of population expansion were detected in the Bahia's maned sloth and in the AFNE common sloth populations. The expansion events are support by Moraes-Barros et al. (2006) data and hypothesis, who proposed that the mtDNA diversity patterns found in the AF common sloth populations would be the result of population expansion after a drastic bottleneck. According with the same authors, these demographic events would be accompanied by population isolation due to Quaternary climate change (De Oliveira et al. 1999; Behling 2002; Auler et al. 2004; Pessenda et al. 2004; Wang et al. 2004; Ledru et al. 2009).

Similar events seem to have originated the genetic diversity of the pygmy sloth. This species has differentiated only recently, about 9000 ya, from the mainland common sloth (Anderson \& Handley 2002). Our data pointed out a population expansion older than the speciation event. It is likely that the demographic event detected would correspond to a common sloth population expansion to the eastern Panama, which was followed by the Isla Escudo de Veráguas formation, isolating the population in a restricted area, forcing size selection, and speciation (Anderson \& Handley 2002). This hypothesis is supported by evidences of forest expansion before the island formation (Bush \& Colinvaux 1990).

The time elapsed since the beginning of the pygmy sloth's isolation could have been insufficient to the species regain genetic diversity. The similar levels of genetic diversity of the AFCS common sloth population could indicate that also this population might have had little time to accumulate new genetic diversity. Nevertheless, as previously emphasized, the whole 
AF common sloth population seems to have long lasting low levels of genetic diversity, compared to the species' indices. In this context, alternatively or complementarily to MoraesBarros' et al. (2006) hypothesis, we propose that the presence of a metapopulation system in AF common sloth population would be responsible for the maintenance of the low genetic diversity. According to Gilpin's (1991), a metapopulation system would prevent the population to regain genetic diversity, stabilizing in a lower genetic equilibrium. We suggest that the AF past climatic changes (De Oliveira et al. 1999; Behling 2002; Auler et al. 2004; Pessenda et al. 2004; Wang et al. 2004; Ledru et al. 2009) originated environmental instability and asynchronic habitat patchiness in a time scale compatible with the common sloth longevity, low migration and low mutation rates' (Sunquist \& Montgomery 1973; Delsuc et al. 2004; Moraes-Barros et al. 2011; this chapter), enabling the formation and maintenance of a metapopulation system (see classical metapopulation definition in Hanski 1991).

While some of the population history and taxonomic status are still obscure (Chiarello et al. 2011), the results presented on this chapter highlight the AF common sloth populations' isolation from other forested habitats, its structure, and genetic depauperation. More than two decades ago, Emmons (1990) advised that the common sloth should have threatened status in areas where its habitat was endangered, namely the AF. Furthermore, the conservation status of the maned sloth, whose populations are also isolated, highly structure and have similar levels of genetic diversity as the AF common sloth (Moraes-Barros et al. 2006; Lara-Ruiz et al. 2008, this chapter) emphasizes that the need of immediate conservation measures for the common sloth can be perceived at a population level, before a full evaluation is possible.

Finally, the common sloth is a charismatic species. This attribute could be used to engage actions to the conservation of the species itself and of the AF, namely as a flagship species. Previous attempts to use flagship species to the AF conservation were more successful to the species itself than to the forest (see lion tamarinds example, Leontopithecus rosalia; Kierulff $e t$ al. 2008). Nevertheless, lion tamarinds, as the maned sloth, are more geographically restricted than the common sloth in AF. Thus the common sloth is known by a larger audience. Moreover, common sloths' conspicuousness of movements, particularly when in the ground, their apparent calm and quietude make this species appealing to all socio-economic groups.

\section{Conclusion}

As expected, the pygmy sloth has extremely low values of genetic diversity and high indices of inbreeding, emphasizing its vulnerability to environmental changes. This genetic depauperation probably resulted from demographic expansion in the mainland, followed by the rapid isolation of Isla Escudo de Veráguas, which potentiated speciation (Anderson \& Handley 2002). Similar events of forest expansion and retraction shaped the genetic diversity patterns found for the common sloth. Most interestingly, these events differentiated AF populations from 
$\mathrm{AMZ}$ ones and caused the genetic depauperation of the AF populations. Either considering the AF common sloth as a unique population or structured in two as detected by our nuclear DNA analyses, or the three mtDNA-based management units (Moraes-Barros et al. 2007), genetic data emphasize the immediate need of conservation actions on these populations, as much as on the vulnerable maned sloth. We believe the degree of threat should be evaluated at the population level, particularly in the Neotropics where data is still lacking and biodiversity is remarkably high. The common sloth could become a flagship species in the mediatization of the neotropical conservation.

\section{Acknowledgments}

The authors would like to acknowledge the institutions, their representatives and teams that have collaborated in sampling: Parque Ambiental Chico Mendes (Joseline Guimarães and Sr. Josué), LNN-UFPA (Pêssi Sousa); Zoo-CE (Vets. Lucio and Leandro), CETAS-CE (Alberto Klefasz), CETAS-PB (Edson Victor), CETAS-AL (Marius Belluci), CETAS-BA (Maria Conceição Pires), UFPE (José Anderson Feijó, Diego Astúa de Moraes and José Eduardo Garcia), Retiro Ecológico (Roberto Siqueira and Sr. Lenilson), UFC (Felipe), UFPB (Flávia Barros, Micheline Lima and Ubiratan Gonçalves), MHN UFAL (Jorge Luiz), Instituto Maracajá (Simonne Chinem and Márcio Motta), DEPAVE-SP (Juliana Summa and Maria Eugênia Summa), Adriana Oliveira, Camila Clozato, and so many others without whom would not be possible to have such sampling effort. Thanks to CTM and CIBIO staffs for technical support (Sofia Mourão, Teresa Luísa Silva, Rita Oliveira, Raquel Godinho and Miguel Carneiro) and Danilo Aqueu Rufo. Sofia M. Silva had an FCT PhD grant (SFRH/BD/40638/2007), Nadia de Moraes-Barros was supported by CAPES, and João S. Morgante was granted with a research award from FAPESP (08/52207-0).

\section{References}

Anderson, R.P., Moraes-Barros, N., Voirin, B. 2011. Bradypus pygmaeus. In: IUCN 2012. IUCN Red List of Threatened Species. Version 2012.2. www.iucnredlist.org. Downloaded on 15 November 2012.

Anderson, R.P., Handley, C.O. 2002. Dwarfism in insular sloths: biogeography, selection and evolutionary rate. Evolution, 56, 1045-1058.

Alfaro, J.W.L, Boubli, J.P., Olson, L.E., Di Fiore, A., Wilson, B., Gutiérrez-Espeleta, G.A., Chiou, L., Schulte, M., Neitzel, S., Ross, V., Schwochow, D., Nguyen, M.T.T., Farias, I., Janson, C.H., Alfaro, M.E. 2011. Explosive Pleistocene range expansion leads to widespread Amazonian sympatry between robust and gracile capuchin monkeys. Journal of Biogeography 39, 272-288. 
Auler, A., Wang, X., Edwards, L., Cheng, H., Cristalli, P., Smart, P., Richards, D. 2004. Quaternary ecological and geomorphic changes associated with rainfall events in presently semi-arid northeastern Brazil. Journal of Quaternary Science 19, 693-701.

Bandelt, H.; Forster, P., Röhl, A. 1999. Median-joining networks for inferring intraspecific phylogenies. Molecular Biology and Evolution 16, 37-48.

Baker, R.J. 2000 Systematics of bats of the family Phyllostomidae based on RAG2 DNA sequences. Museum of Texas Tech University.

Behling, H. 2002. South and southeast Brazilian grasslands during Late Quaternary times: a synthesis. Palaeogeography, Palaeoclimatology, Palaeoecology 177, 19-27.

Buckley, L.B., Davies, T.J., Ackerly, D.D., Kraft, N.J.B., Harrison, S.P., Anacker, B.L., Cornell, H.V., Damschen, E.I., Grytnes, J.A., Hawkins, B.A., McCain, C.M., Stephens, P.R., Wiens, J.J. 2010. Phylogeny, niche conservatism and the latitudinal diversity gradient in mammals. Proceedings of the Royal Society B 277, 2131-2138.

Bunker, D.E., DeClerck, F., Bradford, J.C., Colwell, R.K., Perfecto, I., Phillips, O.L., Sankaran, M., Naeem, S. 2005. Species loss and aboveground carbon storage in a tropical forest. Science 310, 1029-1031.

Bush, M.B., Colinvaux, P.A. 1990. A pollen record of a complete glacial cycle from lowland Panama. Journal of Vegetation Science 1, 105-118.

Ceballos, G., Ehrlich, P.R. 2002. Mammal population losses and the extinction crisis. Science 296, 904- 907.

Chiarello, A., Moraes-Barros, N. 2011. Bradypus torquatus. In: IUCN 2012. IUCN Red List of Threatened Species. Version 2012.2. <www.iucnredlist.org>. Downloaded on 03 December 2012.

Chiarello, A., Moraes-Barros, N., Plese, T. 2011. Bradypus variegatus. In: IUCN 2012. IUCN Red List of Threatened Species. Version 2012.2. www.iucnredlist.org. Downloaded on 03 December 2012.

Cole, M.M. 1960 Cerrado, Caatinga and Pantanal: The distribution and origin of the savanna vegetation of Brazil. The Geographical Journal, 126, 168-179.

Collen B., Ram, M., Zamin, T., McRae, L. 2008. The tropical biodiversity data gap: addressing disparity in global monitoring. Tropical Conservation Science 1, 75-88.

Conservation International do Brasil, Fundação SOS Mata Atlântica, Fundação Biodiversitas, Instituto de Pesquisas Ecológicas, Secretaria do Meio Ambiente do Estado de São Paulo, SEMAD/Instituto Estadual de Florestas-MG. 2000. Avaliação e acções prioritárias para a conservação da biodiversidade da Mata Atlântica e Campos Sulinos. Brasília: MMA/SBF, 40p.

De Oliveira, P.E., Barreto, A.M.F., Suguio, K., 1999. Late Pleistocene/Holocene climatic and vegetational history of the Brazilian caatinga: the fossil dunes of the middle São Francisco River. Palaeogeography, Palaeoclimatology, Palaeoecology 152, 319-337. 
Delsuc, F., Vizcaino, S.F., Douzery, E.J., 2004. Influence of Tertiary paleoenvironmental changes on the diversification of South American mammals: a relaxed molecular clock study within xenarthrans. BMC Evolutionary Biology 4, 11.

Earl, D.A., von Holdt, B.M. 2012. STRUCTURE HARVESTER: a website and program for visualizing STRUCTURE output and implementing the Evanno method. Conservation Genetics Resources 4, 359-361.

Ehrlich, P.R., Daily, G.C., 1993. Population extinction and saving biodiversity. Biodiversity: Ecology, Economics, Policy 22, 64-68.

Emmons, L. 1990. Neotropical rainforest mammals. Chicago: University of Chicago Press. $281 \mathrm{pp}$.

Evanno, G., Regnaut, S., Goudet, J., 2005. Detecting the number of clusters of individuals using the software STRUCTURE: a simulation study. Molecular Ecology 14, 2611-2620.

Excoffier, L., Laval, G., Schneider, S., 2005. Arlequin ver. 3.0: An integrated software package for population genetics data analysis. Evolutionary Bioinformatics Online 1, 47-50.

Frankham, R. 2005. Genetics and Extinction. Biological Conservation 126, 131-140.

Fundação SOS Mata Atlântica, INPE (Instituto Nacional de Pesquisas Espaciais). 2011. Atlas dos remanescentes florestais da Mata Atlântica, período 2008-2010. Fundação SOS Mata Atlântica \& INPE, São Paulo, Brazil.

Garcia, J.E., Vilas Boas, L.A., Lemos, M.V., de Macedo Lemos, E.G., Contel, E.P., 2005. Identification of microsatellite DNA markers for the giant anteater Myrmecophaga tridactyla. Journal of Heredity 96, 600-602.

Gilpin, M., 1991. The genetic effective size of a metapopulation. Biological Journal of the Linnean Society 42, 165-175.

Groombridge, J.J., Jones, C.G., Bruford, M.W., Nichols, R.A. 2000. "Ghost" alleles of the Mauritius kestrel. Nature 403, 616.

Hall, T. 1999. BioEdit: a user-friendly biological sequence alignment editor and analysis program for Windows 95/98/NT. Nucleic Acids Symposium Series 41, 95-98.

Hamilton, M., Pincus, E., Di Fiore, A., Fleischer, R. 1999. Universal linker and ligation procedures for construction of genomic DNA libraries enriched for microsatellites. Biotechniques 27, 500-507.

Hanski, I., 1991. Single-species metapopulation dynamics: concepts, models and observations. Biological Journal of the Linnean Society 42, 17-38.

Hardy, O.J., Vekemans, X., 2002. SPAGeDi: a versatile computer program to analyse spatial genetic structure ate the individual or population levels. Molecular Ecology Notes 2, 618-620.

Hare, M. 2001. Prospects for nuclear gene phylogeography. TRENDS in Ecology and Evolution 16, 700-706. 
Heywood, V.H. 1995. The Global Biodiversity Assessment. United Nations Environment Programme. Cambridge University Press, Cambridge. 1140pp.

Hirsch, A., Chiarello, A.G. 2011. The endangered maned sloth Bradypus torquatus of the Brazilian Atlantic forest: a review and update of geographical distribution and habitat preferences. Mammal Review 42, 35-54.

Höglund, J. 2009. Evolutionary conservation genetics. Oxford University Press.

Hoorn, C., Wesselingh, F.P., ter Steege, H., Bermudez, M.A., Mora, A., Sevink, J., Sanmartín, I., Sanchez-Meseguer, A., Anderson, C.L., Figueiredo, J.P., Jaramillo, C., Riff, D., Negri, F.R., Hooghiemstra, H., Lundberg, J., Stadler, T., Särkinen, T., Antonelli, A., 2010. Amazonia through time: Andean uplift, climate change, landscape evolution, and biodiversity. Science 330, 927-931.

Hudson, R., Kaplan, N. 1985. Statistical properties of the number of recombination events in the history of a sample of DNA sequences. Genetics 111, 147-164.

Hughes, J.B., Daily, G.C., Ehrlich, P.R. 1997. Population Diversity: Its Extent and Extinction. Science 278, 689- 692.

IUCN, 2012. IUCN Red List of Threatened Species. www.iucnredlist.org.

Jullien, N., 2004-2006. AmplifX. Test, manage and design your primers for PCR. http://ifrjr.nord.univ-mrs.fr/AmplifX-Home-page?lang=en.

Kierulff, M.C.M., Rylands, A.B. \& de Oliveira, M.M. 2008. Leontopithecus rosalia. In: IUCN 2012. IUCN Red List of Threatened Species. Version 2012.2. www.iucnredlist.org. Downloaded on 03 December 2012.

Kimura, M. 1983. The neutral theory of molecular evolution. Cambridge University Press, Cambridge, Massachusetts.

Lacy, R.C. 1987. Loss of genetic diversity from managed populations: interacting effects of drift, mutation, immigration, selection, and population subdivision. Conservation Biology 1, 143-158.

Lara-Ruiz, P., Chiarello, A.G., Santos, F.R. 2008. Extreme population divergence and conservation implications for the rare endangered Brazilian Atlantic forest sloth, Bradypus torquatus (Pilosa: Bradypodidae). Biological conservation 141: 1332-1342.

Lavergne, A., Verneau, O., Patton, J.L., Catzeflis, F.M. 2010. Molecular discrimination of two sympatric species of opossum (genus Didelphis: Didelphidae) in French Guiana. Molecular Ecology 6, 889-89.

Ledru, M.-P., Mourguiart, P., Riccomini, C., 2009. Related changes in biodiversity, insolation and climate in the Atlantic rainforest since the last interglacial. Palaeogeography, Palaeoclimatology, Palaeoecology 271, 140-152.

Librado, P., Rozas, J. 2009. DnaSP v5: a software for comprehensive analysis of DNA polymorphism data. Bioinformatics 25, 1451-1452. 
Luck, G.W., Daily, G.C., Ehrlich, P.R. 2003. Population diversity and ecosystem services. Trends in Ecology and Evolution.18, 331-336.

Markert, J.A., Champli, D.M., Gutjahr-Gobell, R., Grear, J.S., Kuhn, A., McGreevy, T.J., Roth, A., Bagley, M.J., Nacci, D.E. 2010. Population genetic diversity and fitness in multiple environments. BMC Evolutionary Biology 10, 13pp.

McConkey, K.R., Drake, D.R. 2006. Flying foxes cease to function as seed dispersers long before they become rare. Ecology 87, 271-276.

Montgomery, G.G., Sunquist, M.E., 1975. Impact of sloths on Neotropical forest energy flow and nutrient cycling. Springer.

Moraes-Barros, N., Giogi, A.P., Silva, S.M., Morgante, J.S. 2010. Reevaluation of the geographical distribution of Bradypus tridactylus Linnaeus, 1758 and B. variegatus Schinz, 1825. Edentata 11, 53-61.

Moraes-Barros, N., Silva, J.A.B., Morgante, J.S. 2011 Morphology, molecular phylogeny, and taxonomic inconsistencies in the study of Bradypus sloths (Pilosa: Bradypodidae). Journal of Mammalogy 92, 86-100

Moraes-Barros, N., Miyaki, C., Morgante, J., 2007. Identifying management units in nonendangered species: the example of the sloth Bradypus variegatus Schinz, 1825. Brazilian Journal of Biology 67, 829-837.

Moraes-Barros, N., Silva, J.A., Miyaki, C.Y., Morgante, J.S., 2006. Comparative phylogeography of the Atlantic forest endemic sloth (Bradypus torquatus) and the widespread three-toed sloth (Bradypus variegatus) (Bradypodidae, Xenarthra). Genetica 126, 189-198.

Moss, W., Peery, M.Z., Gutiérrez-Espeleta, G., Vaughan, C., Herrera, G., Pauli, J., 2012. Isolation and characterization of 18 microsatellite markers for the brown-throated three-toed sloth, Bradypus variegatus. Conservation Genetics Resources 4, 1037-1039.

Murphy, W.J., Sun, S., Chen, Z.Q., Pecon-Slattery, J., O'Brien, S.J. 1999. Extensive conservation of sex chromosome organization between cat and human revealed by parallel radiation hybrid mapping. Genome Research, 9, 1223-1230.

Myers, N., Mittermeier, R.A., Mittermeier, C.G., da Fonseca, G.A.B., Kent, J., 2000. Biodiversity hotspots for conservation priorities. Nature, 403, 853-858.

Neuwald, J.L. 2010. Population isolation exacerbates conservation genetic concerns in the endangered Amargosa vole, Microtus californicus scirpensis. Biological Conservation 143, 2028-2038.

Nyakaana, S., Arctander, P. 1999. Population genetic structure of the African elephant in Uganda based on variation at mitochondrial and nuclear loci: evidence for male-biased gene flow. Molecular Ecology 8, 1105-1115.

Oliveira-Filho AT, Fontes MA. 2000. Patterns of floristic differentiation among Brazilian Atlantic forests in southeastern Brazil and the influence of climate. Biotropica 32: 793-810. 
Olivieri, G.L., Sousa, V., Chikhi, L., Radespiel, U., 2008. From genetic diversity and structure to conservation: Genetic signature of recent population declines in three mouse lemur species (Microcebus spp.). Biological Conservation 141, 1257-1271.

Ooesterhout, C., Hutchinson, W.F., Wills, D., Shipley, P., 2004. MICRO-CHECKER: software for identifying and correcting genotyping errors in microsatellite data. Molecular Ecology Notes. 4, 535-538.

Opazo, J.C., Sloan, A.M., Campbell, K.L., Storz,J.F. 2009. Origin and ascendancy of a chimeric fusion gene: the beta/delta-globin gene of paenungulate mammals. Molecular Biology and Evolution 26, 1469-1478.

Ostrander, E., Jong, P., Rine, J., Duyk, G., 1992. Construction of Small-Insert Genomic DNA Libraries Highly Enriched for Microsatellite Repeat Sequences. Proceedings of the National Academy of Sciences of the United States of America. 89, 3419-3423.

Peakall, R., Smouse, P.E. 2006. GENALEX 6: genetic analysis in Excel. Population genetic software for teaching and research. Molecular Ecology Notes. 6, 288-295.

Pessenda, L.C.R., Gouveia, S.E.M., Aravena, R., Boulet, R., Valencia, E.P.E., 2004. Holocene fire and vegetation changes in southeastern Brazil as deduced from fossil charcoal and soil carbon isotopes. Quaternary International 114, 35-43.

Phillips, S., Anderson, R., Schapire, R. 2006. Maximum entropy modeling of species geographic distributions. Ecological Modelling 190, 231-259.

Pritchard, J.K., Stephens, M., Donnelly, P. 2000. Inference of population structure using multilocus genotype data. Genetics 155, 945-959.

Pritchard, J.K., Wen, X., Falush, D. 2010. Documentation for structure software: Version 2.3. University of Chicago, USA and University of Oxford, UK.

Ramos-Onsins, S.E., Rozas, J. 2002. Statistical properties of new neutrality tests against population growth. Molecular Ecology and Evolution 19, 2092-2100.

Razafindrakoto, A., Quéméré, E., Shore, G.D., McGuire, S.M., Louis Jr, E.E., Brenneman, R.A. 2008. Characterization of 20 microsatellites marker loci in the golden-crowned sifaka (Propithecus tattersalli). Conservation Genetics 9, 1027-1031.

Reed, D.H., Frankham, R. 2003. Correlation between fitness and genetic diversity. Conservation Biology 17, 230-237.

Ricketts, T.H., 2004. Tropical forest fragments enhance pollinator activity in nearby coffee crops. Conservation Biology 18, 1262-1271.

Røed, K.H., Ernest, E.M., Midthjell, L., Msoffe, P.L.M. 2011 Identification and characterization of 17 microsatellite loci in the blue wildebeest, Connochaetes taurinus. Conservation Genetics Resources 3, 181-183.

Rogers, A.R. 1995. Genetic evidence for a pleistocene population explosion. Evolution 49, 608-615. 
Rogers, A.R., Harpending, H. 1992. Population growth makes waves in the distribution of pairwise genetic differences. Molecular Ecology and Evolution 9, 552-569.

Rozen, S., Skaletsky, H., 2000. Primer3 on the WWW for general users and for biologist programmers. In: Krawetz, S. and Misener, S. (eds.) Bioinformatics Methods and Protocols: Methods in Molecular Biology. Humana Press, Totowa, NJ., 365-386.

Ruiz-García, M., Vásquez, C., Pinedo-Castro, M., Sandoval, S., Castellanos, A., Kaston, F., Thoisy, B., Shostell, J. 2012. Phylogeography of the Mountain Tapir (Tapirus pinchaque) and the Central American Tapir (Tapirus bairdii) and the origins of the three Latin-American Tapirs by means of mtcyt-b sequences. In Current Topics in Phylogenetics and Phylogeography of Terrestrial and Aquatic Systems, Kesara Anamthawat-Jónsson (Ed.).

Sambrook, J., Fritsch, E., Maniatis, T. 1989. Molecular cloning: a laboratory manual. Vol. 3. New York: Cold Spring Harbor Laboratory Press.

Sievers, F., Wilm, A., Dineen, D.G., Gibson, T.J., Karplus, K., Li, W., Lopez, R., McWilliam, H., Remmert, M., Söding, J., Thompson, J.D., Higgins, D.G. 2011. Fast, scalable generation of high-quality protein multiple sequence alignments using Clustal Omega. Molecular Systems Biology 7:539.

Silva, M.N.F., Patton J.L. 1998. Molecular phylogeography and the evolution and conservation of Amazonian mammals. Molecular Ecology 7, 475-486.

Skrbinšek, T., Jelenčič, M., Waits, L.P., Potočnik, H., Kos, I., Trontelj, P. 2012. Using a reference population yardstick to calibrate and compare genetic diversity reported in different studies: an example from the brown bear. Heredity 109, 299-305.

Slade, R., Moritz, C., Heideman, A., Hale, P. 1993. Rapid assessment of single copy nuclear DNA variation in diverse species. Molecular Ecology 2, 359-373.

Sonsthagen, S.A., Coonan, T.J., Latta, B.C., Sage, G.K., Talbot, S.L. 2012. Genetic diversity of a newly established population of golden eagles on the Channel Islands, California. Biological Conservation 146, 116-122.

Spielman, D., Brook, B.W., Frankham, R., 2004. Most species are not driven to extinction before genetic factors impact them. Proceedings of the National Academy of Sciences, 101, $15261-15264$.

Stephens, M., Donnelly, P. 2000. Inference in molecular population genetics. Journal of The Royal Statistical Society, Series B 62, 605-655.

Stephens, M., Smith, N., Donnelly, P. 2001. A new statistical method for haplotype reconstruction from population data. American Journal of Human Genetics 68, 978-989.

Sunquist, M.E., Montgomery, G.G. 1973. Activity patterns and rates of movement of twotoed and three-toed sloths (Choloepus hoffmanni and Bradypus infuscatus). Journal of Mammalogy 54, 946-954. 
Tajima, F. 1983. Evolutionary relationship of DNA sequences in finite populations. Genetics $105,437-460$.

Tajima, F. 1989. Statistical method for testing the neutral mutation hypothesis by DNA polymorphism. Genetics 123, 585-595.

Thoisy, B., da Silva, A.G., Ruiz-Garcia, M., Tapia, A., Ramirez, O., Arana, M., Quse, V., Paz-y-Miño, C., Tobler, M., Pedraza, C., Lavergne, A. 2010. Population history, phylogeography, and conservation genetics of the last Neotropical mega-herbivore, the lowland tapir (Tapirus terrestris). BMC Evolutionary Biology 10, 278-293.

Utah Public Lands Research 2005. WWF Terrestrial Ecoregions. Utah Public Lands Research. Draper, Utah, USA.

Vitousek, P.M. 1990. Biological invasions and ecosystem processes: towards an integration of population biology and ecosystem studies. Oikos 57, 7-13

Wang, X., Auler, A., Edwards, L., Cheng, H., Cristalli, P., Smart, P., Richard, D., Shen, C. 2004. Wet periods in northeastern Brazil over the past $210 \mathrm{kyr}$ linked to distant climate anomalies. Nature, 432, 740-743.

Westemeier, R.L., Brawn, J.D., Simpson, S.A., Esker, T.L., Jansen, R.W., Walk, J.W., Kershner, E.L., Bouzat, J.L., Paige, K.N. 1998. Tracking the long-term decline and recovery of an isolated population. Science 282, 1695-1698.

Willig, M.R., Kaufman, D.M., Stevens, R.D. 2003. Latitudinal gradients of biodiversity: Pattern, process, scale, and synthesis. Annual Review of Ecology, Evolution, and Systematics 34, 273-309.

Wright, S. 1977. Evolution and the genetics of populations: experimental results and evolutionary deductions. The University of Chicago Press, Chicago, 3, 611.

Zschokke, S., Armbruster, G.F.J., Ursenbacher, S., Baur, B. 2011. Genetic differences between the two remaining wild populations of the endangered Indian rhinoceros (Rhinoceros unicornis). Biological Conservation 144, 2702-2709. 


\title{
CAPítulo 4. Bradypus variegatus' (common sloth) demography as a model to study the Brazilian Atlantic forest past bridges, paths and processes.
}

Sofia M. Silva, Susana Lopes, Nuno Ferrand, João S. Morgante, \& Nadia de Moraes-Barros (em preparação)

\begin{abstract}
The Brazilian Atlantic forest (AF) is the most threatened South American biome, and one of the most heterogeneous and biodiverse in the world. This biodiversity richness was partially due to intermittent connection with the Amazonian forest, but today the AF is geographically isolated from other forested habitats. The common sloth (Bradypus variegatus) has been an important biological model to create and test hypotheses on this issue. However the molecular markers described so far had low levels of polymorphism hindering analyses on demography and structure. In order to solve this difficulty, we present a new 50 polymorphic microsatellite battery. Previously suggestions on i) connectivity between Amazonia and AF through the northeast, ii) AF colonization in a north-south axis, iii) the bottleneck / isolation / expansion hypothesis, and iv) the division in three management units within AF could be further supported. New insights on metapopulation dynamics within AF were also gathered. This chapter sustains that the common sloth might have been organized as a metapopulation within AF. This system could have been originated by climatic instability and maintained due to environmental heterogeneity and the species biology. Metapopulation dynamics can explain the low genetic diversity levels found within common sloth AF populations. Such a process was never suggested to describe AF mammalian genetic diversity patterns, but we are convinced that other species' genetic diversity patterns within AF can be explained by a similar process.
\end{abstract}

\section{Keywords}

Brazilian Atlantic forest - Common sloth - Metapopulation - Microsatellites

\section{Introduction}

The Brazilian Atlantic forest (AF) heterogeneity is marked by its distinct vegetation types, varying from rain forests, semi-deciduous forests, Araucaria forests, and dune ecosystems such as sandbanks and mangroves (Oliveira-Filho \& Fontes 2000). Currently all these ecosystems are menaced by excessive exploitation and degradation due to human activity (Conservation International do Brasil et al. 2000). Despite this biome has been recognized as a world's Biosphere Reserve (CNRBMA 2009), last estimates report a continuous deforestation in all AF extension (Fundação SOS Mata Atlântica \& INPE 2011). The AF is the most important biodiversity hotspot in South America, with only about $8 \%$ left of its historical range (Myers et 
al. 2000). It is also one of the world's most mammal-rich fauna biome, with a high degree of threat and uniqueness (Ceballos \& Ehrlich 2006, 2009).

Presently, the AF is isolated from all other forested biomes by a savannah-like corridor (Cole 1960). However, its biodiversity seems to be partially due to a past connection with the Amazonian forest (AMZ; reviewed by Silva et al. 2012 Chapter 2). The emergence of extensive gallery forest corridors, and forest expansion in general, have contributed to taxa exchange between the two forested habitats (Costa 2003; Fernandes et al. 2004; Santos et al. 2007; Tchaicka et al. 2007; Cabanne et al. 2008; Vilaça \& Santos 2010). Biogeographic studies have detected the periodicity of these events (Cortés-Ortiz et al. 2003) and the most likely routes of connection: either through the north, the south, or even the centre of Brazil (Costa 2003; Carnaval \& Bates 2007; Quijada-Mascareñas et al. 2007; Martins et al. 2009). Moreover, evidences of climatic instability were collected across the whole AF (De Oliveira et al. 1999; Behling 2002; Auler et al. 2004a; Wang et al. 2004; Pessenda et al. 2004), and past climatic changes within the biome's region seem also to have enhanced its biodiversity (e.g. Cabanne et al. 2008; Fitzpatrick et al. 2009; Thomé et al. 2010).

The study of Bradypus variegatus (common sloth) has been demonstrating the role of the species as a biological model to the study of the AF evolutive history (Moraes-Barros et al. 2006; Carnaval \& Moritz 2008; Martins 2011; Silva et al. 2012 Chapter 2). The common sloth is an interesting example both of the past $\mathrm{AF} / \mathrm{AMZ}$ link and current $\mathrm{AF}$ isolation. A northeastern and a direct north to south route of connection were proposed by the detection of shared mitochondrial DNA (mtDNA) haplotypes between AMZ and AF common sloth populations (Moraes-Barros et al. 2007). However a pronounced differentiation of the AF common sloth populations in relation to the AMZ ones is transversal to mtDNA and distinct nuclear molecular markers (Moraes-Barros et al. 2011; Silva et al. Chapter 3). Also the species demographic events within AF have been correlated with past forest expansion and retraction events (Moraes-Barros et al. 2006, 2007; Carnaval \& Moritz 2008; Martins 2011). Two hypotheses were postulated to explain the genetic diversity patterns of the species within AF: population bottleneck, followed by expansion and isolation (Moraes-Barros et al. 2006), and metapopulation dynamics (Silva et al. Chapter 3). In practical terms, these hypotheses are both grounded in the intensive past climatic instability of the AF area (De Oliveira et al. 1999; Behling 2002; Auler et al. 2004a; Pessenda et al. 2004). However Silva et al. (Chapter 3) proposed a more complex process; rather than just isolating populations, climatic and environmental changes would originate a metapopulation system.

According to the classical and empirical Hanski's et al. (1995) metapopulation definition: i) a metapopulation should be constituted of discrete habitat patches inhabited or not by breeding local populations; ii) all local populations have some probability to go extinct, but they are not likely to disappear at the same time; iii) there is some connectivity among patches, and iv) 
empty suitable habitat patches can be colonized (see Hanski 1991 and Hanski \& Gilpin 1991 for conceptual review on metapopulation's nomenclature). However this definition was seldom suitable to identify metapopulation systems in mammals, especially in medium to large sized ones (reviewed by Elmhagen \& Angerbjörn 2001 and Olivier et al. 2009). Consequently, Elmhagen and Angerbjörn (2001) proposed that the identification of locally discrete breeding subpopulations, and estimates of distinct growth rate among subpopulations, would be enough to support metapopulation systems among medium to large sized mammals. Not surprisingly, within the AF, only a few metapopulation examples can be cited. Small-mammals' were pointed out has having a not classical metapopulation structure, due to the evidence of individuals' dispersal movements between subpopulations (Gentile \& Cerqueira 1995; Pires \& Fernandez 1999; Pires et al. 2002). The puma (Puma concolor) is also supposed to be recently organized in a source-sink metapopulation system due to habitat fragmentation in southeastern Brazil (Miotto et al. 2012).

Moraes-Barros et al. (2006) hypothesis suggests that the climate change would influence populations' demography and isolate them. Precedent mtDNA analyses further supported the evidences of isolation (Moraes-Barros et al. 2011) and expansion (Carnaval \& Moritz 2008; Fig. 1b). The possibility of other bottleneck events within isolated populations was not excluded. Nuclear DNA sequences (nDNA) analyses, detected expansion events, and a different population structure than mtDNA (Fig. 1a). On one hand, the apparent lack of bottleneck signs could be due to the reduced number of markers analyzed and very low values of genetic diversity (Silva et al. Chapter 3). On the other hand, the metapopulation hypothesis suggested that after the bottleneck and expansion events, the low dispersal capacity of the common sloth (Sunquist \& Montgomery 1973), its low evolutionary rate (Delsuc et al. 2004; Moraes-Barros et al. 2011), together with a metapopulation dynamics (extinction and colonization of subpopulations), would maintain low levels of genetic diversity, without signs of a genetic bottleneck (Maruyama \& Kimura 1980; Wade \& McCauley 1988; Gilpin 1991). However, Silva et al. (Chapter 3) could not test this hypothesis, due to the low number and low polymorphism of their microsatellites.

In this context, the main goal of this study was to disentangle the current demographic history and population structure of the common sloth within the AF. In order to do so, i) we described a new and extensive microsatellite battery, with sufficient polymorphism for the AF common sloth populations study; ii) we tested intra and inter-population structure within AF; and iii) we assessed demographic events within populations (Fig. 1c). Finally, we associate the current knowledge on the common sloth population structure within AF conservation (Fig. 1), iv) discriminating three fully geographically coherent and independent management units (MUs), and v) inferring connectivity between AF and AMZ forest. 


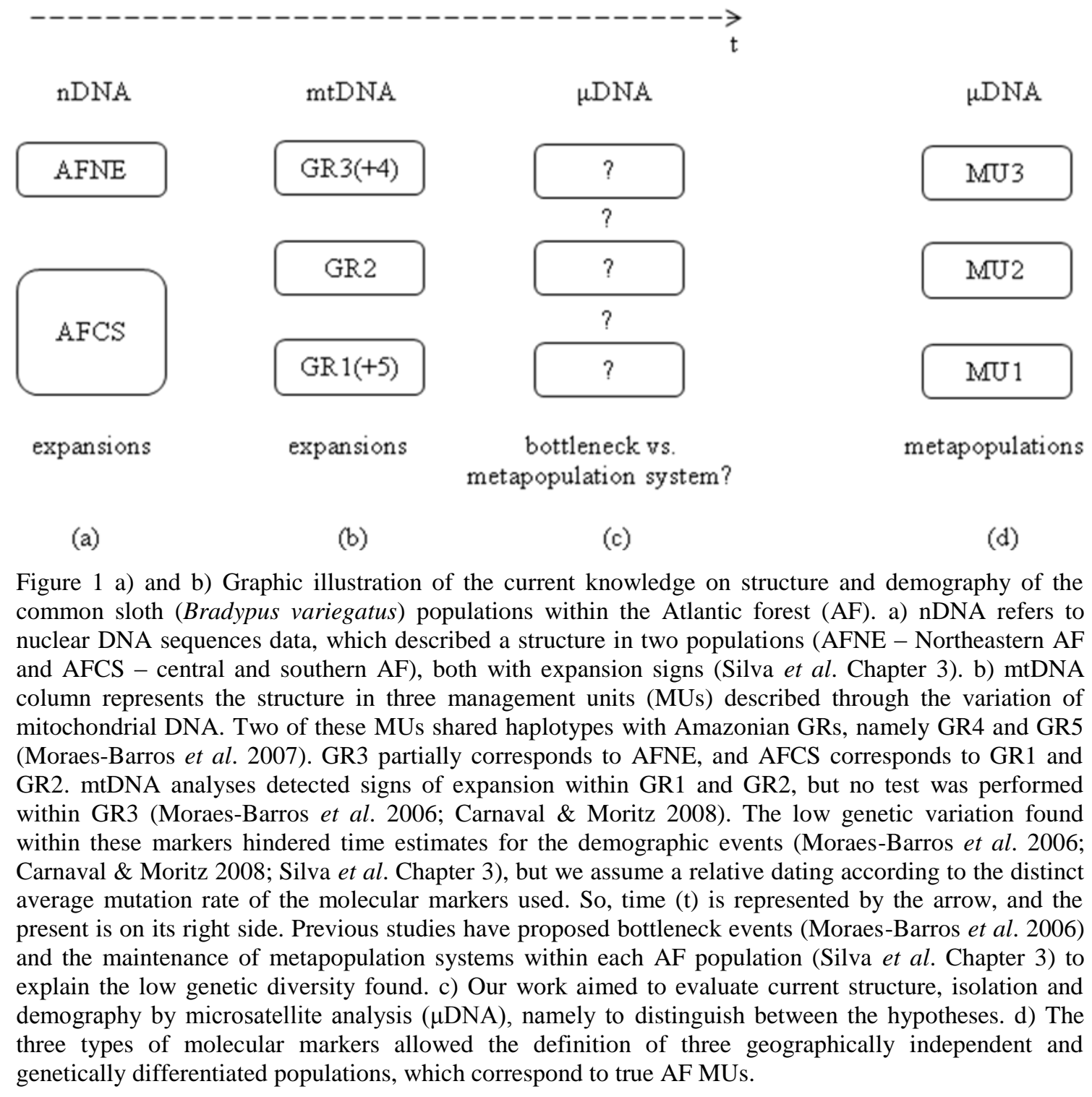

\section{Materials and Methods}

\section{Sample collection}

We have used ninety one common sloth samples previously analyzed either for mtDNA or nuclear DNA (nDNA). DNA extraction is described elsewhere (Moraes-Barros et al. 2002, 2006; Moraes-Barros \& Morgante 2007; Silva et al. Chapter 3). Samples were collected in different geographic regions (GRs) within eastern and western AMZ (AMZEast and AMZWest, respectively) and in three main GRs within AF, previously sampled in Silva et al. (Chapter 3; see also Fig. 2a). Within AF, the southern common sloth AF region (GR1) corresponds to the current species southern limit, in São Paulo (SP) federal state. The larger portion of AF remnants and protected areas are located here (Conservation International do Brasil et al. 2000). This region was pointed by Moraes-Barros et al. (2007) as a MU, although not fully differentiated from Pará federal state (PA; GR5; Fig. 2a). Central AF (GR2) was reported as the 
most biodiverse region, either considering species richness or genetic variability (MoraesBarros et al. 2006; Martini et al. 2007; Fitzpatrick et al. 2009; Thomé et al. 2010; Cabanne et al. 2011). It was considered as mtDNA MU (Moraes-Barros et al. 2007), and together with GR1 formed central/ southern AF (AFCS) nDNA population (Silva et al. Chapter 3; Figs. 1a, 2a). The northern AF is the less studied area. This area partially corresponds to a northern MU described by Moraes-Barros et al. (2007), and represents northeastern AF (AFNE) population described by Silva et al. (Chapter 3; Fig. 1a, 2a). Within this area, AF remnants are restricted just to a thin fragmented belt, with few protected areas (Conservation International of Brasil et al. 2000).

\section{Molecular markers}

A pool of 10 samples from GR1 and GR2 were submitted to the high-throughput microsatellite isolation 454 GS-FLX titanium pyrosequencing technique (GenoSat ${ }^{\circledR}$; Gilles et al. 2011; Malausa et al. 2011). From a total of 60134 reads obtained, 15127 had microsatellite motifs, and 1115 were pointed for primer design for having sufficient flanking segments. Among them, dinucleotides were most abundant, with 872 sequences, followed by 132 trinucleotides, 110 tetranucleotide and just one pentanucleotide. Fifty two di-, tetra-, and pentanucleotide microsatellite markers were selected and amplified through multiplex polymerase chain reactions (PCRs; Table 1). Multiplex amplifications were optimized with the help of MultiPLX 1.0 (Kaplinski et al. 2005), and AmplifX 1.4 (Jullien 2005) to test potential unwanted primers interactions. Amplifications were performed in a final volume of $10 \mu \mathrm{using}$ $5 \mu \mathrm{l}$ of QIAGEN PCR MasterMix, $1 \mu \mathrm{l}$ of DNA extraction (approximately $10 \mathrm{ng}$ of genomic DNA) and $1 \mu \mathrm{L}$ of primer mix. Primer mix consisted of three primers for each locus, following the M13-tailed primer method (Oetting et al. 1995). Four universal M13 primers labeled with FAM, VIC, NED and PET were used at the same concentrations as the reverse primers $(0.25 \mu \mathrm{M})$, and forward primers were 10 -fold less concentrated $(0.025 \mu \mathrm{M})$. PCR program consisted of an initial denaturation at $95^{\circ} \mathrm{C}$ for $15 \mathrm{~min}$., followed by 11 touchdown cycles (denaturation at $95^{\circ} \mathrm{C}$ for $30 \mathrm{sec}$, amplification beginning at $58^{\circ} \mathrm{C}$, and decreasing $0.5^{\circ} \mathrm{C}$ each 1 min. cycle, and extension at $72^{\circ} \mathrm{C}$ for $40 \mathrm{sec}$.), and 29 cycles (with the same denaturation and extension times and temperatures, but with amplifications occurring at $\left.52^{\circ} \mathrm{C}\right)$. Multiplex number six had a slightly different PCR program, which consisted of a shorter touchdown $(9$ cycles, with a starting annealing temperature of $56^{\circ} \mathrm{C}$ ), followed by 34 rather than 29 PCR cycles. Genotyping was performed in an Applied Biosystems 3130xl Genetic Analyzer, and GeneMapper v.4.1 software (Applied Biosystems) was used for fragment size reading.

Genotypes of three other previously described microsatellites were included in our dataset (Silva et al. Chapter 3). 
Table 1 Description of the microsatellites amplified in Bradypus variegatus.

\begin{tabular}{|c|c|c|c|c|c|c|c|c|}
\hline \multirow{2}{*}{$\frac{\text { Multiplex }}{1}$} & \multirow{2}{*}{$\frac{\text { Locus }}{\text { D590 }}$} & \multicolumn{2}{|c|}{ Primers (5'-3') } & \multirow{2}{*}{$\frac{\text { Repeat }}{\mathrm{AC}}$} & \multirow{2}{*}{$\frac{\mathbf{N a}}{6}$} & \multirow{2}{*}{$\frac{\mathbf{A R}(\mathbf{b p})}{10(285-295)}$} & \multirow{2}{*}{$\frac{\text { Ho }}{0,217}$} & \multirow{2}{*}{$\frac{\mathbf{H e}}{0,291}$} \\
\hline & & TACTCCAGGCTTATGGGAGC & CGTGAAAACTGTAGCTTTCTGGA & & & & & \\
\hline & D751 & CAGAATGCAACTGCAGGAGA & TGAGGGAAACAAGGTGCCTA & $\mathrm{AC}$ & 6 & $10(285-275)$ & 0,405 & 0,558 \\
\hline & TT100 & TCCCACATGAGATAGATAGGCA & TCACCTTGCAGTATCATTCTATCA & AGAT & 11 & $40(147-187)$ & 0,644 & 0,803 \\
\hline & TT111 & CATGTCAGCCACTGAAATCAT & GCTGAGCATCTATTAATCTGAGCA & TAGA & 9 & $32(193-225)$ & 0,410 & 0,590 \\
\hline & TT25 & AAAGACATAGAAGATCTTGCCCC & CCAGCTATTGACATGAAATGGA & TTTG & 2 & $4(308-312)$ & 0,044 & 0,044 \\
\hline & TT27 & ATCTTACTCTGCAGTATTTCATGCT & ATGTAGATGATCTGAGACTATGTCCTG & ATAC & 3 & $8(158-166)$ & 0,124 & 0,222 \\
\hline & TT36 & GGATGTGAAGTATTAGTCGGGC & CCAAGACAACTCAAACTGGGA & TATT & 2 & $4(139-143)$ & 0,013 & 0,013 \\
\hline & TT39 & AAGTCCAAGGTAGTTATTCTAAAATGG & ACCGCTACTTGAATGTTCCC & CATC & 7 & $24(309-333)$ & 0,247 & 0,378 \\
\hline & TT41 & GAAATGGAAGGAAGGAGGGA & AAAGCAAACGGAAGTTTAGGC & GGAG & 7 & $24(203-277)$ & 0,369 & 0,644 \\
\hline & TT60 & AGCACTGAGAAATGGGAAGC & GCAGATGTTAACAAATACTCATCACTG & TCTAA & 8 & $28(135-163)$ & 0,573 & 0,766 \\
\hline & TT92 & TGCTGGACATGAACCAGAGA & CACATGGGGCCATTGTCTA & CATC & 1 & $0(204)$ & - & - \\
\hline \multirow[t]{8}{*}{2} & TT31 & TCATTGTTGGTTATACAGATGGAGA & AAGCAGTTTGCTTTGTTAGCTG & GATA & 5 & $16(119-135)$ & 0,180 & 0,246 \\
\hline & TT33 & AAAAGAGCCTGAATGTATGCAA & CAGAGAACTCCAATATACCCCA & TAGA & 5 & $20(189-209)$ & 0,156 & 0,187 \\
\hline & TT47 & GATAATGGCATTTGGGGAGA & САТТTCАССАСССАТТTCСТ & ATGG & 1 & $0(234)$ & - & - \\
\hline & TT50 & AACCTTTTGCCTCATTTTCTG & TCAAGGAGTATGATGTATGCAACC & CTAT & 11 & $40(124-164)$ & 0,367 & 0,538 \\
\hline & TT62 & ACAATAAATAATCAGCTTTGCATCC & AAGCTTGATGTTGTCATGACCTT & ATGG & 8 & $28(251-279)$ & 0,430 & 0,669 \\
\hline & TT67 & GTCCTCATTTCCTAGCCTGG & TGGGGAATTCAACATCACTTC & TAGA & 7 & $24(243-267)$ & 0,356 & 0,709 \\
\hline & TT81 & GAGGGAAGGAGAGGGAAAGA & TGGGTGAAAGAGTGGGTAGG & TCCA & 6 & $20(182-202)$ & 0,418 & 0,536 \\
\hline & TT84 & TTAAACCTGTCTGTATCTATCATCCG & CCTGCCTGTGGAGTGTTG & ATCC & 8 & $36(187-223)$ & 0,478 & 0,625 \\
\hline \multirow[t]{5}{*}{3} & TT107 & TCGAAATCAAGGCATCATCA & TCCTTTATAAATAGGATGAAGAGAGC & TATC & 10 & $40(220-260)$ & 0,560 & 0,808 \\
\hline & TT58 & CCAACTGTAGCACCCTGTCA & CGTACAGATGAACAGGGGAA & TACC & 6 & $20(166-186)$ & 0,311 & 0,605 \\
\hline & TT73 & TTCAGCCTAAGAGCATCCAGA & TGAAGGGATGGACGGATAAG & ATCT & 9 & $32(129-161)$ & 0,605 & 0,752 \\
\hline & TT82 & TGATGTCATTTCAAAGTCTCATTTC & GATATAGACAGATGATCGGATGATAG & TCTAA & 10 & $44(177-221)$ & 0,326 & 0,602 \\
\hline & TT93 & TCCTGTGGATTGCATTTTCA & TGTCTGTCTAATGGTCTGTCTATCTG & GATA & 8 & $28(270-298)$ & 0,646 & 0,791 \\
\hline
\end{tabular}




\begin{tabular}{|c|c|c|c|c|c|c|c|c|}
\hline \multirow{2}{*}{$\frac{\text { Multiplex }}{4}$} & \multirow{2}{*}{$\frac{\text { Locus }}{\text { TT103 }}$} & \multicolumn{2}{|c|}{ Primers (5'-3') } & \multirow{2}{*}{$\frac{\text { Repeat }}{\text { ATCT }}$} & \multirow{2}{*}{$\frac{\mathbf{N a}}{7}$} & \multirow{2}{*}{$\frac{\mathbf{A R} \text { (bp) }}{24(172-196)}$} & \multirow{2}{*}{$\begin{array}{c}\text { Ho } \\
0,548\end{array}$} & \multirow{2}{*}{$\frac{\mathbf{H e}}{0,753}$} \\
\hline & & GATGTTCTGGGCCCTCTGTA & GATGATGGTGTTGGGTGGA & & & & & \\
\hline & TT106 & GGCAACCATTGAAGGTTCTG & GTCCTCCTTTCTCTGCCTCC & GATA & 9 & $32(115-147)$ & 0,557 & 0,723 \\
\hline & TT75 & CTCGAATTTTCCTCCTGCAC & GTTTTGTTTCACTCCCTGCC & CATC & 9 & $32(228-260)$ & 0,297 & 0,374 \\
\hline & TT79 & GGTGACTGTTTCCAAAATACTTCA & TCCAGAAATAGTCCTCACCCA & TAGA & 7 & $28(159-187)$ & 0,484 & 0,691 \\
\hline & TT95 & AGGACCCCTCTGACTTGCTA & TTCAAAAGTGTGCTCACATCA & GGAT & 9 & $40(293-333)$ & 0,416 & 0,688 \\
\hline & TT97 & AGCTCTTGTTGATTCTGTTTCC & AAAACGGCTCTTGGTTACGA & TATC & 6 & $20(154-174)$ & 0,494 & 0,568 \\
\hline \multirow[t]{8}{*}{5} & P104 & AGCTCCTATTTACCTCTTCAGCC & TGTGCAAAGGTACTATGCGAT & CATCT & 17 & $100(112-212)$ & 0,593 & 0,890 \\
\hline & TT101 & TGACCATTGTTCCAAATCTGTT & AAGGATAGATGGGTGCATGG & ATCC & 7 & $32(153-185)$ & 0,612 & 0,705 \\
\hline & TT105 & ACAGCTTCAAACCACCATGC & TTGGTTGAATTAATGAATATGTGGA & CCAT & 6 & $24(113-137)$ & 0,460 & 0,597 \\
\hline & TT110 & GCCACACCTTCCATGACTTC & CAACAGACCTCAAACCAGCA & CTAT & 7 & $24(322-346)$ & 0,707 & 0,757 \\
\hline & TT48 & TCACTACCACATTGATTAAGCACC & AGAGCAGGGTCCCACTTCTT & CCAT & 4 & $12(194-206)$ & 0,242 & 0,495 \\
\hline & TT55 & ACTTCTTTTCCAATACAGGTGC & GCAAGATGGATGTGTAGGTAGG & CTAT & 10 & $36(114-150)$ & 0,529 & 0,718 \\
\hline & TT77 & TGGGTCTAGCTCCACACTGTT & ACTCGATTTCAGGAACCACG & CATC & 8 & $32(206-238)$ & 0,308 & 0,581 \\
\hline & TT80 & CTGAGGTTGGGGAAATTTTG & AAACAAATTATATTCTTGTGATTGCAT & TATG & 6 & $24(106-130)$ & 0,451 & 0,611 \\
\hline \multirow[t]{6}{*}{6} & TT57 & ACAGTTGGGTGGGTCACATC & ACTCTCGCCATCTTGGTGAA & GGAT & 3 & $8(296-304)$ & 0,149 & 0,296 \\
\hline & TT66 & TGGATCAGCCCTATTATCATCC & TCCAACCCTCTGTAGCCACT & GATG & 6 & $20(263-283)$ & 0,153 & 0,393 \\
\hline & TT70 & TGCTTTGGGGATTTATGACA & TATAGGGATCACTGGATGGG & ATCC & 6 & $28(111-139)$ & 0,437 & 0,665 \\
\hline & TT78 & AGATTTCCACAATTACTGCTTTGA & TGCATGTATGTATGTATAGCTGCTT & TAGA & 6 & $24(151-175)$ & 0,506 & 0,622 \\
\hline & TT90 & CGCCCACCAGCCTTTATAGT & AGCCACTGGTCCACCTATCA & ATGG & 6 & $20(208-228)$ & 0,356 & 0,605 \\
\hline & TT91 & TAACACAGAAAGTTGAGGGACTG & TGATAGACACCAATAAATATTTGCC & CATC & 7 & $24(140-164)$ & 0,333 & 0,617 \\
\hline \multirow[t]{5}{*}{7} & D507 & TGCTTTGTATATGAAGATGCTGC & CACAGACTGCTGTGTTTGGC & $\mathrm{AC}$ & 3 & $6(306-312)$ & 0,084 & 0,082 \\
\hline & D560 & GACTGGAGTCCTGCCTTGAA & TGTGGTTCCTGGTGACTCTG & GT & 3 & $4(188-192)$ & 0,047 & 0,069 \\
\hline & D656 & GCAGTTTGAGTTTCTCTAAAGGCT & GGTTGGTGCCACTGAGTTTC & $\mathrm{TC}$ & 4 & $6(117-123)$ & 0,281 & 0,555 \\
\hline & D719 & CTGAGGAATGGCCAAAGTGT & САTTTCTATACTCACTAGAATGGATGC & TG & 5 & $8(182-190$ & 0,371 & 0,678 \\
\hline & D728 & TGCACTTTCCTGGCCTTC & CTCACCGTGACTGCTCCAC & $\mathrm{AC}$ & 5 & $12(304-316)$ & 0,00 & 0,523 \\
\hline
\end{tabular}




\begin{tabular}{|c|c|c|c|c|c|c|c|c|}
\hline Multiplex & Locus & \multicolumn{2}{|c|}{ Primers (5'-3') } & Repeat & $\mathbf{N a}$ & AR (bp) & Ho & He \\
\hline & D729 & CCTGGATGCAGTAAAGAGCC & AGGAGGTGGTATGTATGTAAGCA & $\mathrm{CA}$ & 6 & $16(290-306)$ & 0,337 & 0,486 \\
\hline & D828 & TTTCACACCCAATAGAATGGC & ATTTACССТTCСТCTTCAATGAT & $\mathrm{AC}$ & 10 & $18(111-129)$ & 0,550 & 0,746 \\
\hline & D835 & GTTCCCCAACCTTGTGCTTA & TCAGATCTACTTGTTGGTGCAA & TG & 9 & $16(175-191)$ & 0,311 & 0,710 \\
\hline Mean (s.d.) & & & & & $7(3)$ & $23(16)$ & $0,370(0,181)$ & $0,552(0,218)$ \\
\hline
\end{tabular}

$\mathrm{Na}$ - number of alleles; AR (bp) - allelic range in base pairs (minor and larger alleles); Ho - observed heterozygosity; He - expected heterozygosity.

(a)

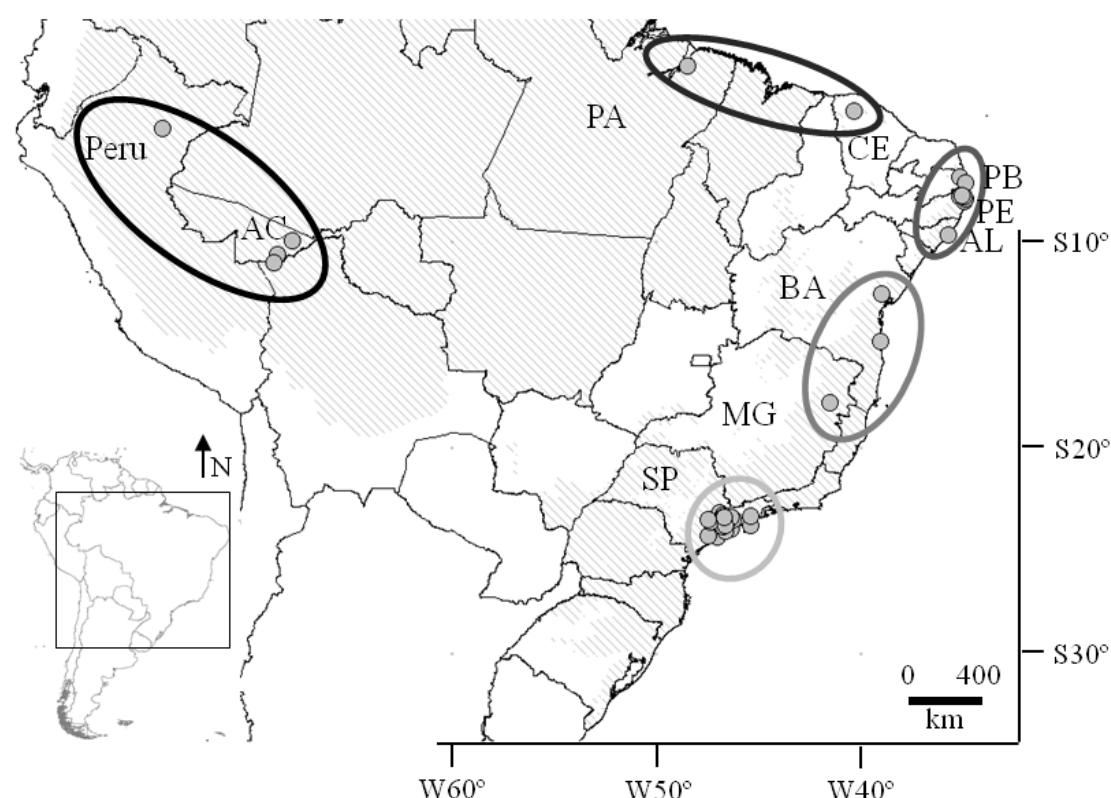

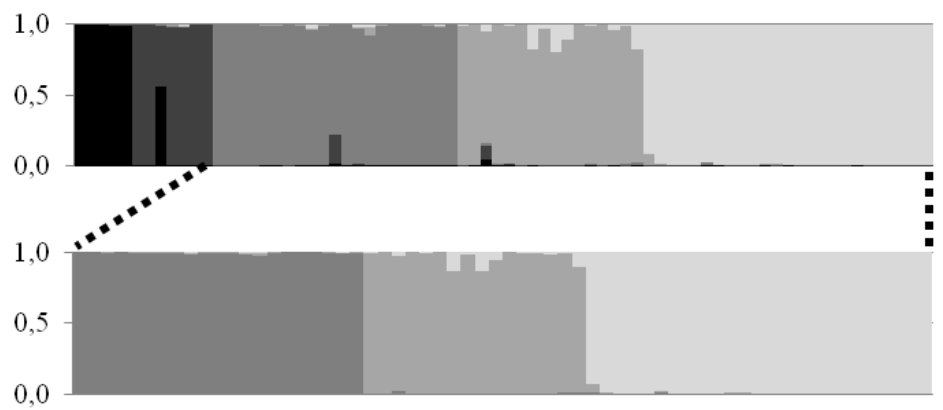

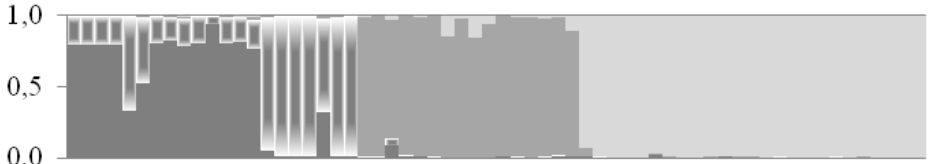

1,0

0,5 (b)

Figure 2. Sampling localities for individuals of Bradypus variegatus included in this study and respective population structure. Samples from São Paulo (SP) correspond to the geographic region 1 (GR1) and are represented by light gray color; samples from Minas Gerais (MG) and Bahia (BA) are colored in gray and belong to GR2; individuals collected in Alagoas (AL) correspond to GR3, and together with samples from Paraíba (PB) and Pernambuco (PE) constitute northeastern Atlantic forest population (AFNE), with the dark gray. Samples collected in Ceará (CE) and Pará (PA; GR5) represent eastern Amazonia population (AMZEast) and is depicted by light black. Finally samples from Peru (GR8) and Acre (AC) are depicted in black, and correspond to western Amazonia population (AMZWest). GRs are named after Moraes-Barros et al. (2007), and populations according with Silva et al. (Chapter 3). (a) The Atlantic forest in eastern Brazil and the Amazonian forest in the northwest are depicted in dashed lines. (b) The most likely number of clusters in Bayesian analyses of the total dataset was five: AMZWest, AMZEast, AFNE, GR2, GR1. (c) AF was most likely divided in three clusters: AFNE, GR2 and GR1. Nevertheless geographically coherent subdivisions within AFNE separating AL samples (d) and differentiation within GR2 dividing MG from BA (e) could also be depicted within STRUCTURE 2.3.4 graphics. 
Genotyping errors, due to the presence of null alleles, stuttering, allelic dropout and typographic errors, were checked by a randomization test implemented in MICRO-CHECKER 2.2.3, performing $10^{4}$ randomizations, considering a confidence level of $95 \%$, and omitting missing data (van Oosterhout et al. 2004).

Although the reduced sloths' vagility (Sunquist \& Montgomery 1973; Montgomery \& Sunquist 1975), possible genealogical relationships were tested by a maximum likelihood algorithm implemented in ML-Relate (Kalinowski et al. 2006).

The Fst-outlier detection method implemented in the software LOSITAN was used to detect potential loci under selection. The two consecutive runs approach was performed, with $10^{5}$ simulations, and considering a 99\% confidence interval (Beaumont \& Nichols 1996; Antão et al. 2008). Only localities with more than five individuals sampled were used.

Further markers' characterization was performed using the unrelated individuals' dataset. Linkage disequilibrium and Hardy-Weinberg equilibrium tests were performed under default settings in Arlequin 3.11 (Excoffier et al. 2005).

\section{Population differentiation and DNA diversity indices}

Population structure was assessed hierarchically, by analyzing the full dataset, only AF samples or within population structure. A widely used Bayesian algorithm implemented in STRUCTURE 2.3.4 was chosen (Pritchard et al. 2000). This algorithm was already used to test AF population structure at nuclear DNA level (Silva et al. Chapter 3). However, the discriminant analysis of principal components (DAPC) was recently indicated for analyses of multiple genes, because its better performance under more complex models of population structure (Jombart et al. 2010). We compared STRUCTURE 2.3.4 results with the DAPC's implemented in the ADEGENET 1.3-4 R package (Jombart 2008).

Bayesian runs under the default model of admixture consisted of 10 iterations, with a length of burnin period of $10^{5}$ and a number of MCMC repeats after burnin equal to $10^{6}$ (Pritchard et al. 2000). Total and AF datasets were simulated to be divided into one to 10 clusters, and structure within each population was evaluated for $1 \leq \mathrm{k} \leq 5$. Bayesian results were also submitted to the Evanno's method, given that patterns of dispersal among populations are thought to be heterogeneous (Evanno et al. 2005; Earl \& vonHoldt 2012).

The optimal number of clusters was determined in ADEGENET by running successive ks in the "find.clusters" function. According to the dataset under analysis, up to 12 or 20 clusters were tested. In each case, the number of clusters corresponding to the lowest associated Bayesian information criterion (BIC) was considered the optimal $\mathrm{k}$ value. The number of retained principal components (PCs) of PCA varied with datasets, from 12 to 50. For the optimal $\mathrm{k}$ value and corresponding number of retained PCs, the "dapc" function was then executed using group composition inferred from the "find.clusters" analysis. The most 
contributing alleles for the structure found were also determined (Jombart et al. 2010; Jombart 2012). Whenever necessary, within populations' assignment of individuals to clusters was optimized by the "optim.a.score" function (Jombart 2012).

Hierarchical analysis of molecular variance (AMOVA), and diversity and differentiation indices were estimated with Arlequin 3.11 (Excoffier et al. 2005). Isolation by distance was tested by Mantel test performed in GenAlEx 6.5 (Peakall \& Smouse 2012), with 9999 permutations, and linear regressions performed in R 2.15.1 (R Development Core Team 2008).

\section{Historical demographic patterns}

Demographic fluctuations were inferred by moment-based methods implemented in Bottleneck 1.2.02, and by a long-term Bayesian test, the VarEff implemented in R 2.15.1 (Cornuet \& Luikart 1996; Luikart et al. 1998; Piry et al. 1999; R Development Core Team 2008; Chevalet \& Nikolic 2010; Nikolic \& Chevalet 2012).

Bottleneck 1.2.02 tests are particularly adequate to detect recent declines in population sizes (Piry et al. 1999). Specifically, the mode shift test is suited to find population reductions occurred in the last 40 to 80 generations (Luikart et al. 1998). Given the six years of generation time for the common sloth (Anderson \& Handley 2002), this software was used to detect the possible effects of current fragmentation and habitat reduction of the last 500 years on the common sloth AF populations (Conservation International do Brasil et al. 2000; Fundação SOS Mata Atlântica \& INPE 2011).

As for VarEff, it is a newly described algorithm, but has the advantages of estimating both the time since the demographic event, past effective population sizes, and the most probable number of past demographic events (Chevalet \& Nikolic 2010; Nikolic \& Chevalet 2012).

Bottleneck 1.2.02 tests, both mode-shift and the Wilcoxon tests, were performed for $10^{3}$ iterations, under the two-phase mutation model (TPM). We have considered a TPM with a variance among multiple steps of 12 or 30 , and with a proportion of single-step mutations of 95\% or 70\%, respectively (Piry et al. 1999; Givens et al. 2007).

Given the little information available for the common sloth biology and demographic history (reviewed by Hayssen 2010), wide but realistic priors were used (Heller et al. 2008), for VarEff estimates. Times since the origin of the populations were based on the pairwise time of population differentiation estimates performed in Arlequin 3.11 (Gaggiotti \& Excoffier 2000). Generation time was assumed to be of six years (Anderson \& Handley 2002). Mutation rate was considered to be the average mutation rate described for mammal species $\left(1.0 \times 10^{-4}\right.$; Jarne \& Lagoda 1996), and half of it, since previous mtDNA and nuclear DNA rate estimates indicate that sloths are a slow evolving group (Delsuc et al. 2004; Moraes-Barros et al. 2011). VarEff estimates the current effective population size, and this value was used to set the corresponding prior, nevertheless a large variance for this estimate was also assumed, as recommended by the 
authors (Nikolic \& Chevalet 2012). After exploratory runs, $10^{6}$ iterations were considered to be sufficient to obtain robust estimates. A total of 36 models were run in VarEff for each subdataset, covering the three mutation models (TPM and geometric mutation model, GMM, were considered to have $95 \%$ of single step mutation), the two mutation rates, and different numbers (one to six) of past demographic events.

\section{Results}

\section{Molecular markers}

We were able to amplify and unambiguously genotype 52 markers in seven multiplexes of five to 11 microsatellites, but two were monomorphic in the total dataset (TT92 and TT47; Table 1). From the final set of 50 polymorphic microsatellites, the localities corresponding to AFNE population had three monomorphic markers, GR2 had two more, and in GR1 a total of 16 markers were monomorphic.

We found no evidences that our microsatellites' dataset had sex linked loci. All AMZ samples had unexpected allele sizes in markers TT36 and TT57, and AMZWest in TT111. These sizes were considered as genotyping errors, and scored as missing data. MICROCHECKER 2.2.3 detected null alleles in Pernambuco (PE; TT58 and P104), Minas Gerais (MG; TT100, TT97, and TT105) and SP (TT62, TT67 and TT81) localities. However, results were inconsistent, even performing a higher number of randomizations $\left(10^{4}\right)$. Thus, these markers should be used with caution.

Eleven individuals were excluded from the total dataset, given that they could not be considered unrelated to others. So a new dataset of seventy four unrelated individuals was obtained.

No locus was consistently departing from Hardy-Weinberg equilibrium in the geographic subsets, and no consistent departure from linkage disequilibrium was detected. However TT36, D656 and D728 were Fst outliers, showing signs of being under selection, and so they were excluded from posterior analyses.

\section{Population differentiation and DNA diversity indices}

The mean estimate of the log likelihood of the data for each number of clusters (mean Est $\mathrm{LnP}(\mathrm{X} / \mathrm{k})$ ) was higher for $\mathrm{k}=5$. These simulations, at $\mathrm{k}=5$, separated AMZ populations (eastern and western) from those sampled within the AF, the northern (AFNE), central (GR2), and southern (GR1) areas (Fig. 2b). These populations were also differentiated by the analysis of the population structure within AF (Fig. 2c). Interestingly, for $\mathrm{k}=4$ within AF, some iterations distinguished AL (GR3) from PE and Paraíba (PB) federal states, and in others MG was separated from Bahia (BA) localities (Figs. 2d, 2e). Using the Evanno's method, the full 
dataset could only be divided in two clusters, grouping AMZ with AFNE, and GR1 with GR2. Focusing on the AF populations, the highest delta $\mathrm{k}$ also corresponded to $\mathrm{k}=2$. STRUCTURE 2.3.4 runs at $\mathrm{k}=2$ presented the GR2 as an intermediate between AFNE and GR1, but the low $\alpha$ values supported a low miscegenation between clusters.

The "find.clusters" function within DAPC software identified $\mathrm{k}=4$ as the optimal number of clusters for the total dataset, corresponding to a sharp and clear decline in BIC values (Fig. 3a). We retained 50 PCs of PCA, represented in three discriminant functions, which explained $95.6 \%$ of the total genetic variability. AMZ populations were grouped together, and separated from three AF populations. The minimum spanning tree between DAPC clusters connected AMZ to AFNE (Fig. 3b), a scenario supported by STRUCTURE 2.3.4 simulations for $\mathrm{k}=2$. The most contributing allele to this differentiation was allele 194 (TT48) followed by several other: 123 (TT106), 301 (TT95), 194 (TT48), 115 (TT70) and 148 (TT91), and finally alleles 185 and 187 (D835).

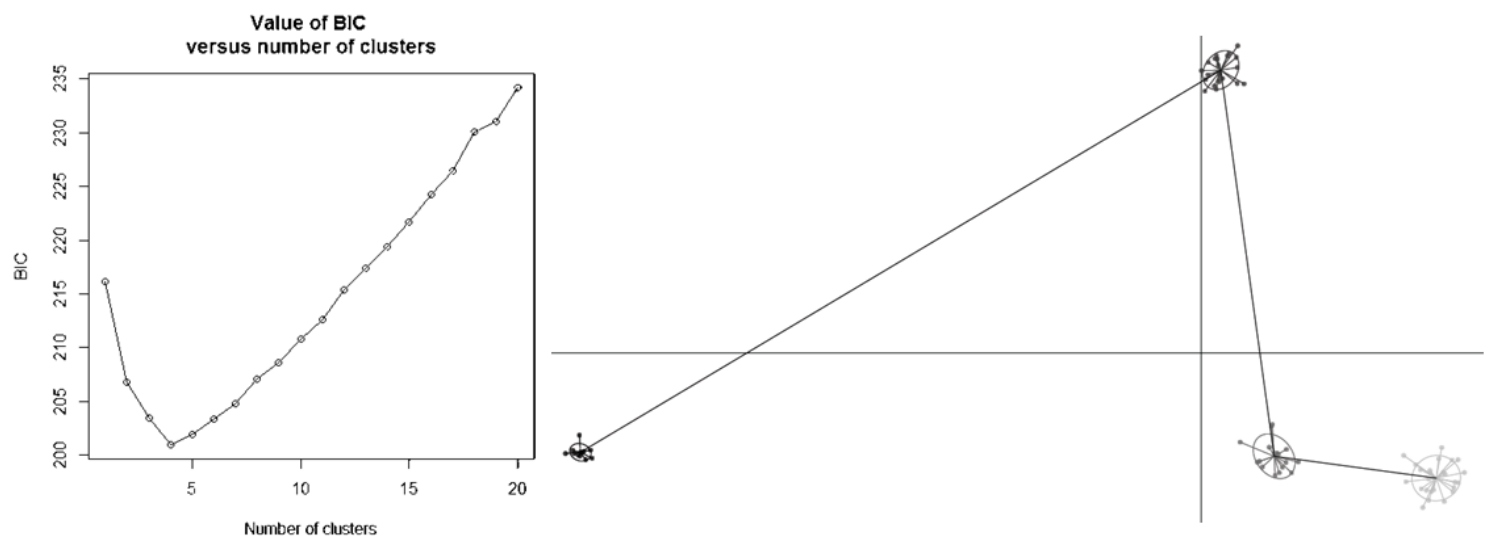

(a)

(b)

Figure 3 Principal results from clustering analyses of the common sloth (Bradypus variegatus) total dataset performed with the discriminant analysis of principal components implemented in ADEGENET 1.3-4 R package (Jombart 2008; Jombart et al. 2010). (a) Bayesian information criterion (BIC) reached its lowest value for $\mathrm{k}=4$. (b) Minimum spanning tree between sampling localities connects Amazonia (black) with the northeast of Brazil (dark gray). Central Atlantic forest (AF) population is depicted in gray and southern AF in light gray.

Within $\mathrm{AF}, \mathrm{a} \mathrm{k}=3$ corresponded unambiguously to the lowest $\mathrm{BIC}$ value. In this case, 94.7\% of the genetic variation was explained by the retained 40 PCs of PCA, and two discriminant functions. Allele 309 (TT95) and alleles 185 and 187 (D835) accounted for the differentiation of the three regions.

Population differentiation indices were high and significant, both considering five (AMZWest - AMZEast $F s t=0.0960 ; p=0.0018$ ) or four populations (Table 2). 
Table 2 Pairwise population differentiation indices estimated for the Atlantic forest Bradypus variegatus populations. AMZ - Amazonia; AFNE northeastern Atlantic forest named after Silva et al. (Chapter 3) and geographic regions 1 and 2 (GR) numbered after Moraes-Barros et al. (2007). Above diagonal: Fst indices. Below diagonal: $p$ - values, estimated over 10100 permutations.

\begin{tabular}{ccccc} 
& AMZ & AFNE & GR2 & GR1 \\
\hline AMZ & & 0.171 & 0.228 & 0.423 \\
AFNE & 0.0000 & & 0.167 & 0.366 \\
GR2 & 0.0000 & 0.0000 & & 0.241 \\
GR1 & 0.0000 & 0.0000 & 0.0000 & \\
\hline
\end{tabular}

$\mathrm{A} \mathrm{k}=4$ was accepted as the most likely number of populations within our total dataset, given the results of the clustering and classical methods of population differentiation used. This option is based in four reasons: i) although a good guide procedure, STRUCTURE 2.3.4 performs worse in detecting the true number of clusters if the population structure is characterized by isolation by distance (Pritchard et al. 2000); ii) probably an insufficient number of replicas was used to perform the Evanno's methods (Waples \& Gaggiotti 2006); iii) DAPC performs better under complex population structure models (Jombart et al. 2010); iv) our focus was the AF and most of the methods agreed on the existence of three clusters within this region, being irrelevant the number of groups described within AMZ for the following analyzes.

Further structure within each population was also explored. Within GR1, STRUCTURE 2.3.4 failed to detect population structure. Nevertheless very close BIC values for $\mathrm{k}=1$ and $\mathrm{k}=$ 2 were estimated during DAPC (51.60 and 51.72 respectively). Since we were very conservative in estimating genealogical relationships within localities, we reanalyzed the data with an increased sample size, including the individuals considered related. Also, we optimize assignments with the "optime.a.score" function. After these procedures, the lowest BIC values corresponded to $\mathrm{k}=2$. Genetic differentiation indices supported structure within GR1 ( $F s t=$ $0.25 ; p=0.0000$ ), and the existence of a continental group and another one more close to the coast were found (Fig. S1).

The same procedure was applied to GR2, given that close BIC values were obtained by DAPC for $\mathrm{k}=1$ and $\mathrm{k}=2$ (43.09 and 43.11 respectively). GR2 clusters corresponded to a BA and a MG groups, also described by STRUCTURE 2.3.4, and supported by genetic differentiation indices $(F s t=0.12 ; p=0.0002)$.

DAPC did not detect population differentiation within AFNE, but both $\mathrm{LnP}(\mathrm{X} / \mathrm{k})$ and genetic differentiation indices supported AFNE structure within three (GR3, PE and PB; Table 3).

AMOVA was performed both with the total dataset $(\mathrm{k}=4)$, and AF dataset $(\mathrm{k}=3)$. For the total dataset, differences among populations $(27.26 \%)$ were higher than the differences within populations $(9.37 \%)$. The inverse was verified for the AF dataset, indicating further structure within populations $(27.50 \%$ and $72.50 \%$, respectively). 
A statistically significant isolation by distance (IBD) was supported by Mantel test $\left(\mathrm{R}^{2}=\right.$ 0.6352, $p=0.0207)$. Particularly, a significant correlation between genetic differentiation and distance was detected, from AMZEast to the northeastern Brazil and towards the southern AF $\left(\mathrm{R}^{2}=0.935 p=0.0329\right)$. Table 4 depicts that this genetic differentiation is accompanied by a variability loss, including the number of private alleles, which was higher for AFNE (23), intermediate for GR2 (18), and much lower for GR1 (just 1 private allele was found, in a frequency smaller than 0.03). Significant inbreeding coefficients were estimated for the AF populations.

Furthermore migration estimates were geographically coherent, and decreased successively from AMZ to AFNE, GR2 and GR1 (Table 5).

Table 3 Pairwise population differentiation indices estimated within Bradypus variegatus AFNE population (named after Silva et al. Chapter 3). PB - Paraíba, PE - Pernambuco and AL - Alagoas federal states. AL corresponds to Moraes-Barros et al. (2007) geographic region number 3. Above diagonal: Fst indices. Below diagonal: $p$-values, estimated over 10100 permutations.

\begin{tabular}{cccc} 
& PB & PE & AL \\
\hline PB & & 0.18 & 0.27 \\
PE & 0.0029 & & 0.061 \\
AL & 0.0081 & 0.0001 & \\
\hline
\end{tabular}

\section{Historical demographic patterns}

BOTTLENECK 1.2.02 demographic changes' tests found no variation in populations' sizes, except for AFNE under the TPM model with higher variance among multiple steps and lower probability of single-step mutations $(p=0.00303$; one-tailed test for heterozygosity excess; Supplementary Material S2). All mode-shift tests detected normal L-shaped distributions.

As for Vareff, the most plausible number of demographic events for all datasets was one, because this model presented the nearest values for the mean, median and mode of the effective size across generations (Nikolic \& Chevalet 2012). The three GRs presented constant effective population sizes, about $3000(\approx 2000-4000)$ for GR1, $6750(\approx 4500-9000)$ for GR2, and 8250 $(\approx 5500-11000)$ for AFNE. Intervals were obtained by considering either a $1.0 \times 10^{-4}$ or $5.0 \times 10^{-5}$ mutation rate, respectively.

\section{Discussion}

Previous attempts to describe polymorphic microsatellites for the AF common sloth did not succeeded using a traditional microsatellites' enriched library method (Silva et al. Chapter 3). Thus we have used the modern high-throughput sequencing methodology. There through is expected a priori the discovery of a larger number of microsatellite sequences (Malausa et al. 
2011). Although the number and type of microsatellite repeats herein described were in agreement with similar publications for other vertebrates (e.g. Castoe et al. 2012; Luo et al. 2012 ), only about $65 \%$ of the newly described polymorphic markers were variable within GR1 (Table 4). Undoubtedly, after all the attempts, the extensive lack of variable markers is not an artifact, but a GR1's feature. This region has the lowest genetic diversity of all the common sloth populations genetically assessed so far, and even as low as the vulnerable maned sloth $(B$. torquatus), and the critically endangered pygmy sloth (B. pygmaeus) (Silva et al. Chapter 3).

Table 4. Mean genetic diversity indices and population specific Fis, for all the polymorphic microsatellites loci from the Bradypus variegatus Atlantic forest populations. The mean number of genotypes (Mn) and private alleles (MPa), the mean allelic range (MAR), and the averaged observed (MHo) and expected (MHe) heterozygosities are presented. AFNE northeastern Atlantic forest named after Silva et al. (Chapter 3) and geographic regions 1 and 2 (GR) numbered after Moraes-Barros et al. (2007). AMZ - Amazonian population, for reference.

\begin{tabular}{cccccccc} 
& Mn & MNa & MPa & MAR (bp) & MHo & MHe & Fis $(\boldsymbol{p}$-value) \\
\hline AMZ & $21.67 \pm 3.01$ & $5.89 \pm 2.25$ & $2.11 \pm 0.23$ & $22.17 \pm 14.90$ & $0.60 \pm 0.22$ & $0.72 \pm 0.18$ & $0.093(0.0040)$ \\
& & & & & & & \\
AFNE & $38.41 \pm 4.36$ & $4.10 \pm 1.76$ & $0.42 \pm 0.10$ & $13.61 \pm 9.14$ & $0.46 \pm 0.20$ & $0.56 \pm 0.22$ & $0.120(0.0002)$ \\
& & & & & & & \\
GR2 & $31.73 \pm 0.92$ & $3.84 \pm 1.86$ & $0.37 \pm 0.08$ & $12.22 \pm 9.52$ & $0.43 \pm 0.22$ & $0.52 \pm 0.23$ & $0.171(0.0003)$ \\
& & & & & & & \\
GR1 & $46.78 \pm 4.18$ & $2.58 \pm 0.87$ & $0.02 \pm 0.02$ & $7.22 \pm 5.26$ & $0.34 \pm 0.19$ & $0.38 \pm 0.21$ & $0.139(0.0021)$ \\
\hline
\end{tabular}

Table 5. Absolute number of migrants per generation (Excoffier et al. 2006) exchanged between Bradypus variegatus populations. AMZ - Amazonia; AFNE northeastern Atlantic forest named after Silva et al. (Chapter 3) and geographic regions 1 and 2 (GR) numbered after Moraes-Barros et al. (2007).

\begin{tabular}{cccc} 
& AMZ & AFNE & GR2 \\
\hline AFNE & 2.430 & & \\
GR2 & 1.695 & 2.497 & \\
GR1 & 0.682 & 0.865 & 1.577 \\
\hline
\end{tabular}

Conversely, the AFNE has the highest genetic diversity indices within AF. This is probably due to the proximity with AMZ. The highest migration rates estimated correspond to exchange of migrants between these regions (Table 5). Either classical indices of population differentiation, and clustering methods support that samples collected in AMZ are more closely related to samples from northeastern AF. IBD measures indicated that this link is most likely to occur with AMZEast. Several examples in the literature support the past connection between 
eastern AMZ and northeastern AF in detriment of other potential routes (Ribas \& Miyaki 2004; Tchaicka et al. 2007; Vilaça \& Santos 2010). However which localities contributed most to this connection is yet unsolved. Moraes-Barros et al. (2007) described mtDNA haplotype sharing between GR3 and GR4, a region that we did not sampled. We have sampled localities within Ceará (CE) federal state, which is geographically closer to GR3 than GR4, and CE was clearly differentiated from GR3. We increased sampling closer to GR3, and although PE and PB localities could be included within a larger GR3, these two localities were more similar with each other than localities sampled within Moraes-Barros' et al. (2007) GR3. Furthermore, we could unambiguously exclude a recent connection between AMZEast (GR5) and southern AF (GR1), by clearly differentiating these regions (Table 2; Figs. 2, 3). Our data support that mtDNA sharing between these populations was probably the consequence of the low sampling, ancestral polymorphism sharing or the result of past occasional translocation of individuals from GR1 to GR5 (Moraes-Barros et al. 2007; Moraes-Barros pers. comm.). The population structure described by our microsatellites analyses solve mtDNA and nDNA sequences geographical discrepancies (Moraes-Barros et al. 2007; Silva et al. Chapter 3), and support the full recognition of the three independent MUs within AF. MU1 corresponds to GR1, MU2 to GR2, and was already evidenced as an independent MU by Moraes-Barros et al. (2007), and MU3, which corresponds to AFNE population described by Silva et al. (Chapter 3). MU designations will be used hereafter.

Within AF, the genetic diversity decline from northeastern Brazil to the southeast is likewise evident in mtDNA and nuclear sequences. All molecular markers described so far for these populations, suggest a positive correlation between Fst and geographic distance (Moraes-Barros et al. 2007; Silva et al. Chapter 3). Altogether, these evidences support the influence of a path of colonization from the north to southern AF on current patterns of genetic diversity (MoraesBarros et al. 2006, 2007). The marked diversity decline in distinct molecular markers hints an ancient genetic diversity loss, likely during the AF colonization (Moraes-Barros et al. 2006; Silva et al. Chapter 3; this Chapter). Severe bottleneck events followed by rapid population expansion can account for severe diversity losses (Gilpin 1991), and in fact, AF common sloth populations seem to have expanded (Silva et al. Chapter 3). Currently, isolation of the populations within AF is supported by our low migration rate estimates. Altogether, these evidences sustain the demographic events suggested by Moraes-Barros' et al. (2006) hypothesis. However, under this scenario, low levels of genetic diversity would have been aggravated by local bottlenecks. Long-term models for detecting demographic changes did not detect any bottleneck event, within AF populations.

The demographic hypothesis for the AF common sloth for the existence of a metapopulation system could be verified, but also not straightforward. Fulfilling Hanski et al. (1995) metapopulation definition can be quite difficult in medium sized mammals such as the common 
sloth (Elmhagen \& Angerbjörn 2001; Olivier et al. 2009), but our empirical data support the more practical Elmhagen \& Angerbjörn (2001) criteria. We validate the existence of locally distinct breeding units, by estimating high and significant levels of population differentiation within populations (majority Fst values > 0.12). Moreover, after the origin of a metapopulation system, climate was instable and cyclic, probably influencing heterogeneously the availability of forested habitats, both temporally and geographically (Behling 1997; Auler et al. 2004b; Wang et al. 2004; Ledru et al. 2009). This environmental dynamics supports the assumptions of asynchrony in the subpopulations dynamics, and consequently supports the hypothesis that the genetic diversity increased was hindered by subpopulations extinctions and recolonizations (Gilpin 1991; Hanski et al. 1995). Further sampling will allow us to further test the type of metapopulation.

The existence of an established metapopulation system, or at least the long-lasting low genetic diversity, hinders the effects of the current habitat fragmentation. Moment-based methods, only detected a bottleneck event in MU3. This might indicate that recent climatic or anthropogenic fragmentation affected MU3. In fact the available habitat is more limited within the northeastern AF (Fundação SOS Mata Atlântica \& INPE 2011). However, this result is more likely to be a false positive due to the violation of the assumption of no structure within MU3.

Howsoever, within AF, population deforestation is severe (Fundação SOS Mata Atlântica \& INPE 2011), and current habitat fragmentation can increase population structure to prejudicial divisions (e. g. Miotto et al. 2012). Besides high structure, the AF common sloth populations present low levels of genetic diversity (Moraes-Barros et al. 2002, 2006, 2007; Silva et al. Chapter 3; this chapter), and significant inbreeding signs (Table 4). Nevertheless, Fis values were smaller than 0.2. If true inbreeding is occurring or if these estimates are just the consequence of the low genetic variability needs to be further evaluated. So, the definition of distinct MUs (Moraes-Barros et al. 2007, this chapter), and the suggestion use of the common sloth as a flagship species (Silva et al. Chapter 3) are probably insufficient measures to conserve AF common sloth uniqueness. The species biology is still obscure. Just to illustrate this lack of information, only last year was published the first study on the species mating system in Costa Rica (Pauli \& Peeri 2012); breeding season is not fully described (Hayssen 2010); animals densities (Montgomery \& Sunquist 1975; Queiroz 1995; Ballesteros et al. 2009), and home ranges are also quite distinct across the species territory (Sunquist \& Montgomery, 1973; Vaughan et al. 2007; Pauli \& Peeri 2012). Furthermore, apart some opportunistic field reports (Lara-Ruiz \& Srbeck-Araujo 2006; Bezerra et al. 2008; Silva et al. Chapter 6), and small studies (Soares \& Carneiro 2002), often in highly humanized habitats (Manchester \& Jorge, 2009), within AF this information is virtually inexistent. Together with the campaigns suggested by Silva et al. (Chapter 3), we recommend to increase local-scaled ecological studies within the 
AF territory. Understanding the species' biological requirements will facilitate the success of enhancing connectivity within each MU, and among MUs.

\section{Conclusion}

The common sloth populations from the AMZ and the AF were connected in the past by a northeastern route. Probably from the northeast, the common sloth colonized the rest of the AF territory, expanding to the south. More than one burst of expansion is likely. During this colonization process, genetic diversity was lost by expansion events and founder effects. Isolation of populations within $\mathrm{AF}$ originated genetically divergent populations, which correspond to three MUs. More recently, a metapopulation system was originated by climatic instability and maintain due to environmental heterogeneity and the common sloth's biology. Past metapopulation dynamics were never suggested as a process to describe AF mammalian genetic diversity patterns. Most likely because classical metapopulation systems are uncommon in medium to large animals, and the description of metapopulations mostly rely on current empirical data. However, we show that it can be applied to the common sloth, a known biological model to the study of the AF biogeography. It seems reasonable that other species' genetic diversity can be explained by a similar process.

\section{Acknowledgments}

Authors acknowledge the working teams who collaborated in sampling: Parque Ambiental Chico Mendes (Joseline Guimarães and Sr. Josué), LNN-UFPA (Pêssi Sousa); Zoo-CE (Vets. Lucio and Leandro), CETAS-CE (Alberto Klefasz), CETAS-PB (Edson Victor), CETAS-AL (Marius Belluci), CETAS-BA (Maria Conceição Pires), UFPE (José Anderson Feijó, Diego Astúa de Moraes and José Eduardo Garcia), Retiro Ecológico (Roberto Siqueira and Sr. Lenilson), UFC (Felipe), UFPB (Flávia Barros, Micheline Lima and Ubiratan Gonçalves), MHN UFAL (Jorge Luiz), Instituto Maracajá (Simonne Chinem and Márcio Motta), DEPAVESP (Juliana Summa and Maria Eugênia Summa), Adriana Oliveira, Camila Clozato, and so many others without whom would not be possible to have such sampling effort. Thanks to Ana C. Pavan, Felipe Martins, Kelly Nunes and CTM and LABEC staffs for technical support and analytical discussions. Sofia M. Silva had an FCT PhD grant (SFRH/BD/40638/2007), Nadia de Moraes-Barros was supported by CAPES, and João S. Morgante was granted with a research award from FAPESP (08/52207-0).

\section{References}

Anderson RP, Handley CO, Jr.( 2002) Dwarfism in insular sloths: biogeography, selection, and evolutionary rate. Evolution 56, 1045-1058. 
Antão T, Lopes A, Lopes RJ, Beja-Pereira A, Luikart G. (2008) LOSITAN: a workbench to detect molecular adaptation based on a Fst-outlier method. BMC Bioinformatics 9, 323.

Auler AS, Wang X, Edwards RL, Cheng H, Cristalli PS, Smart PL, Richards DA (2004) Palaeoenvironments in semi-arid northeastern Brazil inferred from high precision mass spectrometric speleothem and travertine ages and the dynamics of South American rainforests. Speleogenesis and Evolution of Karst Aquifers 2, 1-4.

Auler AS, Wang X, Edwards RL, Cheng H, Cristalli PS, Smart PL, Richards DA (2004) Quaternary ecological and geomorphic changes associated with rainfall events in presently semi-arid northeastern Brazil. Journal of Quaternary Science 19, 693-701.

Ballesteros J, Reyes K, Racero J (2009) Estructura poblacional y etología de Bradypus variegatus en fragmento de bosque seco tropical, Córdoba - Colombia. RevistaMVZ Córdoba 14, 1812-1819.

Beaumont MA, Nichols RA (1996). Evaluating loci for use in the genetic analysis of population structure. Proceedings of the Royal Society B: Biological Sciences 263, 1619-1626.

Behling H (2002) South and southeast Brazilian grasslands during Late Quaternary times: a synthesis. Palaeogeography, Palaeoclimatology, Palaeoecology 177, 19-27.

Behling H, Negrelle R, Colinvaux PA (1997) Moderns pollen rain data from the tropical Atlantic rain forest, Reserva Volta Velha, South Brazil. Review of Palaeobotany and Palynology 97, 287-299.

Bezerra BM, Souto AdS, Halsey L, Schiel N (2008) Observation of brown-throated threetoed sloths: mating behaviour and the simultaneous nurturing of two young. Journal of Ethology $26,175-178$.

Cabanne GS, d'Horta FM, Sari EH, Santos FR, Miyaki CY (2008) Nuclear and mitochondrial phylogeography of the Atlantic forest endemic Xiphorhynchus fuscus (Aves: Dendrocolaptidae): biogeography and systematics implications. Molecular Phylogenetics and Evolution 49, 760-773.

Cabanne GS, D'Horta FM, Meyer D, Silva JMC, Miyaki CY (2011) Evolution of Dendrocolaptes platyrostris (Aves: Furnariidae) between the South American open vegetation corridor and the Atlantic forest. Biological Journal of the Linnean Society 103, 801-820.

Carnaval AC, Bates JM (2007) Amphibian DNA shows marked genetic structure and tracks pleistocene climate change in northeastern Brazil. Evolution 61, 2942-2957.

Carnaval AC, Moritz C (2008) Historical climate modelling predicts patterns of current biodiversity in the Brazilian Atlantic forest. Journal of Biogeography 35, 1187-1201.

Castoe TA, Streicher JW, Meik JM, Ingrasci MJ, Poole AW, Koning AP, Campbell JA, Parkinson CL, Smith EN, Pollock DD (2012) Thousands of microsatellite loci from the venomous coralsnake Micrurus fulvius and variability of select loci across populations and related species. Molecular Ecology Resources 12, 1105-1113. 
Ceballos G, Ehrlich PR (2006) Global mammal distributions, biodiversity hotspots, and conservation. Proceedings of the National Academy of Sciences 103, 19374-19379.

Ceballos G, Ehrlich PR (2009) Discoveries of new mammal species and their implications for conservation and ecosystem services. Proceedings of the National Academy of Sciences 106, 3841-3846.

Chevalet C, Nikolic N (2010) The distribution of coalescence times and distances between microsatellite alleles with changing effective population size. Theoretical Population Biology $77,152-163$.

CNRBMA - Conselho Nacional da Reserva da Biosfera da Mata Atlântica (2009) Reserva da Biosfera da Mata Atlântica: revisão e atualização dos limites e zoneamento da Reserva da Biosfera da Mata Atlântica em base cartográfica digitalizada: fase VI. São Paulo, Brazil. 119 p.

Cole MM (1960) Cerrado, Caatinga and Pantanal: The distribution and origin of the savanna vegetation of Brazil. The Geographical Journal 126, 168-179.

Conservation International do Brasil, Fundação SOS Mata Atlântica, Fundação Biodiversitas, Instituto de Pesquisas Ecológicas, Secretaria do Meio Ambiente do Estado de São Paulo, Instituto Estadual de Florestas-MG (2000) Avaliação e acções prioritárias para a conservação da biodiversidade da Mata Atlântica e Campos Sulinos (ed. Ministério do Meio Ambiente and Secretaria de Biodiversidade e Florestas), p. 40.

Cornuet JM, Luikart G (1996) Description and power analysis of two tests for detecting recent population bottlenecks from allele frequency data. Genetics 144, 2001-2014.

Cortés-Ortiz L, Bermingham E, Rico C, Rodríguez-Luna E, Sampaio I, Ruiz-García M (2003) Molecular systematics and biogeography of the Neotropical monkey genus, Alouatta. Molecular Phylogenetics and Evolution 26, 64-81.

Costa LP (2003) The historical bridge between the Amazon and the Atlantic Forest of Brazil: a study of molecular phylogeography with small mammals. Journal of Biogeography 30, 71-86.

De Oliveira PE, Barreto AMF, Suguio K (1999) Late Pleistocene/Holocene climatic and vegetational history of the Brazilian caatinga: the fossil dunes of the middle São Francisco River. Palaeogeography, Palaeoclimatology, Palaeoecology 152, 319-337.

Delsuc F, Vizcaino SF, Douzery EJ (2004) Influence of Tertiary paleoenvironmental changes on the diversification of South American mammals: a relaxed molecular clock study within xenarthrans. BMC Evolutionary Biology 4, 11.

Earl DA, vonHoldt BM (2012) STRUCTURE HARVESTER: a website and program for visualizing STRUCTURE output and implementing the Evanno method. Conservation Genetics Resources 4, 359-361.

Elmhagen B, Angerbjörn A (2001) The applicability of metapopulation theory to large mammals. Oikos 94, 89-100. 
Evanno G, Regnaut S, Goudet J (2005) Detecting the number of clusters of individuals using the software structure: a simulation study. Molecular Ecology 14, 2611-2620.

Excoffier L, Laval G, Schneider S (2005) Arlequin (version 3.0): an integrated software package for population genetics data analysis. Evolutionary Bioinformatics Online 1, 47-50.

Fernandes DS, Franco FL, Fernandes R (2004) Systematic revision of the genus Lachesis Daudin, 1803 (Serpentes, VIPERIDAE). Herpetologica 60, 245-260.

Fitzpatrick SW, Brasileiro CA, Haddad CFB, Zamudio KR (2009) Geographical variation in genetic structure of an Atlantic Coastal Forest frog reveals regional differences in habitat stability. Molecular Ecology 18, 2877-2896.

Fundação SOS Mata Atlântica, INPE (2011) Atlas dos remanescentes florestais da Mata Atlântica período 2008-2010, p. 120. Fundação SOS Mata Atlântica and Instituto Nacional de Pesquisas Espaciais - INPE, São Paulo.

Gaggiotti OE, Excoffier L (2000) A simple method of removing the effect of a bottleneck and unequal population sizes on pairwise genetic distances. Proceedings of the Royal Society B: Biological Sciences 267, 81-87.

Gentile R, Cerqueira R (1995) Movement patterns of five species of small mammals in a Brazilian restinga. Journal of Tropical Ecology 11, 671-677.

Gilles A, Meglecz E, Pech N, Ferreira S, Malausa T, Martin JF (2011) Accuracy and quality assessment of 454 GS-FLX Titanium pyrosequencing. BMC Genomics 12, 245.

Gilpin M (1991) The genetic effective size of a metapopulation. Biological Journal of the Linnean Society 42, 165-175.

Givens GH, Huebinger RM, Bickham JW, George JC, Suydam R (2007) Patterns of genetic differentiation in bowhead whales (Balaena mysticetus) from the western Arctic. In: Annual Meeting of the Scientific Committee of the International Whaling Commission. International Whaling Commission, Anchorage, USA.

Hanski I (1991) Single-species metapopulation dynamics: concepts, models and observations. Biological Journal of the Linnean Society 42, 17-38.

Hanski I, Gilpin M (1991) Metapopulation dynamics: brief history and conceptual domain. Biological Journal of the Linnean Society 42, 3-16.

Hanski I, Pakkala T, Kuussaari M, Lei G (1995) Metapopulation persistence of an endangered butterfly in a fragmented landscape. Oikos, 21-28.

Hayssen V (2010) Bradypus variegatus (Pilosa: Bradypodidae). Mammalian Species 42, 1932 .

Heller R, Lorenzen ED, Okello JB, Masembe C, Siegismund HR (2008) Mid-Holocene decline in African buffalos inferred from Bayesian coalescent-based analyses of microsatellites and mitochondrial DNA. Molecular Ecoogy 17, 4845-4858. 
Jarne P, Lagoda PJ (1996) Microsatellites, from molecules to populations and back. Trends in Ecology \& Evolution 11, 424-429.

Jombart T (2008) Adegenet: a R package for the multivariate analysis of genetic markers. Bioinformatics 24, 1403-1405.

Jombart T (2012) A tutorial for Discriminant Analysis of Principal Components (DAPC) using adegenet 1.3-4.

Jombart T, Devillard S, Balloux F (2010) Discriminant analysis of principal components: a new method for the analysis of genetically structured populations. BMC Genetics 11, 94.

Jullien N (2005) Amplifx Version 1.3. 6. URL http://ifrjr. nord. univ-mrs. fr/AmplifX6Home-page.

Kalinowski ST, Wagner AP, Taper ML (2006) ML-relate: a computer program for maximum likelihood estimation of relatedness and relationship. Molecular Ecology Notes 6, 576-579.

Kaplinski L, Andreson R, Puurand T, Remm M (2005) MultiPLX: automatic grouping and evaluation of PCR primers. Bioinformatics 21, 1701-1702.

Lara-Ruiz P, Srbek-Araujo A (2006) Comportamento potencialmente reprodutivo da preguiça-comum, Bradypus variegatus (Xenarthra, Bradypodidae): observações de campo. Edentata 7, 44-46.

Ledru M-P, Mourguiart P, Riccomini C (2009) Related changes in biodiversity, insolation and climate in the Atlantic rainforest since the last interglacial. Palaeogeography, Palaeoclimatology, Palaeoecology 271, 140-152.

Luikart G, Allendorf FW, Cornuet JM, Sherwin WB (1998) Distortion of allele frequency distributions provides a test for recent population bottlenecks. The Journal of Heredity 89, 238247.

Luo W, Nie Z, Zhan F, Wei J, Wang W, Gao Z (2012) Rapid development of microsatellite markers for the endangered fish Schizothorax biddulphi (Günther) using next generation sequencing and cross-species amplification. International Journal of Molecular Sciences 13, 14946-14955.

Manchester A, Jorge W (2009) Biological data of a population of sloths (Bradypus variegatus) in a square of Teófilo Otoni, Minas Gerais, Brazil. Naturalia 32, 81-86.

Malausa T, Gilles A, Meglécz E, Blanquart H, Duthoy S, Costedoat C, Dubut V, Pech N, Castagnone-Sereno P, Délye C, Feau N, Frey P, Gauthier P, Guillemaud T, Hazard L, Le Corre V, Lung-Escarmant B, Malé P-JG, Ferreira S, Martin J-F (2011). High-throughput microsatellite isolation through 454 GS-FLX Titanium pyrosequencing of enriched DNA libraries. Molecular Ecology Resources 11, 638-644.

Martini A, Fiaschi P, Amorim A, Paixão J (2007) A hot-point within a hot-spot: a high diversity site in Brazil's Atlantic Forest. Biodiversity and Conservation 16, 3111-3128. 
Martins FM (2011) Historical biogeography of the Brazilian Atlantic forest and the Carnaval-Moritz model of Pleistocene refugia: what do phylogeographical studies tell us? Biological Journal of the Linnean Society 104, 499-509.

Martins FM, Templeton AR, Pavan AC, Kohlbach BC, Morgante JS (2009) Phylogeography of the common vampire bat (Desmodus rotundus): marked population structure, Neotropical Pleistocene vicariance and incongruence between nuclear and mtDNA markers. BMC Evolutionary Biology 9, 294.

Maruyama T, Kimura M (1980) Genetic variability and effective population size when local extinction and recolonization of subpopulations are frequent. Proceedings of the National Academy of Sciences 77, 6710-6714.

Miotto RA, Cervini M, Begotti RA, Galetti Jr PM (2012) Monitoring a Puma (Puma concolor) population in a fragmented landscape in Southeast Brazil. Biotropica 44, 98-104.

Montgomery GC, Sunquist, ME (1975) Impact of sloths on Neotropical forest energy flow and nutrient cycling. In: Tropical Ecological Systems: Trends in Terrestrial and Aquatic Research. Edited by Golley FB, Medina E 69-98. New York: Springer Verlag.

Moraes-Barros N, Morgante JS (2007) A simple protocol for the extraction and sequence analysis of DNA from study skin of museum collections. Genetics and Molecular Biology 30, 1181-1185.

Moraes-Barros N, Morgante JS, Miyaki CY (2002) Genetic diversity in different populations of sloths assessed by DNA fingerprinting. Brazilian Journal of Biology 62, 503-508.

Moraes-Barros N, Miyaki CY, Morgante JS (2007) Identifying management units in nonendangered species: the example of the sloth Bradypus variegatus Schinz, 1825. Brazilian Journal of Biology 67, 829-837.

Moraes-Barros N, Silva JA, Miyaki CY, Morgante JS (2006) Comparative phylogeography of the Atlantic forest endemic sloth (Bradypus torquatus) and the widespread three-toed sloth (Bradypus variegatus) (Bradypodidae, Xenarthra). Genetica 126, 189-198.

Moraes-Barros N, Silva JA, Morgante JS (2011) Morphology, molecular phylogeny, and taxonomic inconsistencies in the study of Bradypus sloths (Pilosa: Bradypodidae). Journal of Mammalogy 92, 86-100.

Myers N, Mittermeier RA, Mittermeier CG, da Fonseca GA, Kent J (2000) Biodiversity hotspots for conservation priorities. Nature 403, 853-858.

Nikolic N, Chevalet C (2012) Package "VarEff" - Variation of effective population size.

Oetting WS, Lee HK, Flanders DJ, Wiesner GL, Sellers TA, King RA (1995) Linkage analysis with multiplexed short tandem repeat polymorphisms using infrared fluorescence and M13 tailed primers. Genomics 30,450-458

Oliveira-Filho AT, Fontes MAL (2000) Patterns of floristic differentiation among Atlantic forests in Southeastern Brazil and the influence of climate. Biotropica 32, 793-810. 
Olivier PI, Van Aarde RJ, Ferreira SAMM (2009) Support for a metapopulation structure among mammals. Mammal Review 39, 178-192.

Pauli JN, Peery MZ (2012) Unexpected strong polygyny in the brown-throated three-toed sloth. PloS one 7, e51389.

Peakall R, Smouse PE (2012) GenAlEx 6.5: genetic analysis in Excel. Population genetic software for teaching and research - an update. Bioinformatics 28, 2537-2539.

Pessenda LCR, Gouveia SEM, Aravena R, Boulet R, Valencia EPE (2004) Holocene fire and vegetation changes in southeastern Brazil as deduced from fossil charcoal and soil carbon isotopes. Quaternary International 114, 35-43.

Pires AS, Koeler Lira P, Fernandez FAS, Schittini GM, Oliveira LC (2002) Frequency of movements of small mammals among Atlantic Coastal Forest fragments in Brazil. Biological Conservation 108, 229-237.

Pires AS, Fernandez FAS (1999) Use of space by the marsupial Micoureus demerarae in small Atlantic Forest fragments in south-eastern Brazil. Journal of Tropical Ecology 15, 279290.

Piry S, Luikart G, Cornuet JM (1999) BOTTLENECK: A computer program for detecting recent reductions in the effective population size using allele frequency data. The Journal of Heredity 90, 502-503.

Pritchard JK, Stephens M, Donnelly P (2000) Inference of population structure using multilocus genotype data. Genetics 155, 945-959.

Queiroz HL (1995) Preguiças e guaribas. Os mamíferos folívoros arborícolas do Mamirauá. Brasília: CNPq-Sociedade Civil Mamirauá.

Quijada-Mascareñas JA, Ferguson JE, Pook CE, Salomão MDG, Thorpe RS, Wüster W (2007) Phylogeographic patterns of trans-Amazonian vicariants and Amazonian biogeography: the Neotropical rattlesnake (Crotalus durissus complex) as an example. Journal of Biogeography 34, 1296-1312.

R Development Core Team (2008) R: A language and environment for statistical computing. R Foundation for Statistical Computing, Vienna, Austria. ISBN 3-900051-07-0, URL http://www.R-project.org.

Ribas CC, Miyaki CY (2004) Molecular systematics in Aratinga parakeets: species limits and historical biogeography in the 'solstitialis' group, and the systematic position of Nandayus nenday. Molecular Phylogenetics and Evolution 30, 663-675.

Santos AMM, Cavalcanti DR, Silva JMCd, Tabarelli M (2007) Biogeographical relationships among tropical forests in north-eastern Brazil. Journal of Biogeography 34, 437446. 
Silva SM, Moraes-Barros N, Ribas CC, Ferrand N, Morgante JS (2012) Divide to conquer: a complex pattern of biodiversity depicted by vertebrate components in the Brazilian Atlantic Forest. Biological Journal of the Linnean Society 107, 39-55. (Chapter 2)

Soares CA, Carneiro RS (2002) Social behavior between mothers x young of sloths Bradypus variegatus Schinz, 1825 (Xenarthra: Bradypodidae). Brazilian Journal of Biology 62, 249-252.

Sunquist ME, Montgomery GG (1973) Activity patterns and rates of movement of two-toed and three-toed sloths (Choloepus hoffmanni and Bradypus infuscatus). Journal of Mammalogy 54, 946-954.

Tchaicka L, Eizirik E, De Oliveira TG, Candido JF, Jr., Freitas TR (2007) Phylogeography and population history of the crab-eating fox (Cerdocyon thous). Molecular Ecology 16, 819838.

Thomé MT, Zamudio KR, Giovanelli JG, Haddad CF, Baldissera FA, Jr., Alexandrino J. (2010) Phylogeography of endemic toads and post-Pliocene persistence of the Brazilian Atlantic Forest. Molecular Phylogenetics and Evolution 55, 1018-31.

van Oosterhout C., Hutchinson WF, Wills DPM, Shipley P (2004) Micro-checker: software for identifying and correcting genotyping errors in microsatellite data. Molecular Ecology Notes, 4, 535-538.

Vaughan C, Ramírez O, Herrera G, Guries R (2007) Spatial ecology and conservation of two sloth species in a cacao landscape in limón, Costa Rica. Biodiversity and Conservation 16, 2293-2310.

Vilaça ST, Santos FR (2010) Biogeographic history of the species complex Basileuterus culicivorus (Aves, Parulidae) in the Neotropics. Molecular Phylogenetics and Evolution 57, 585-597.

Wade MJ, McCauley DE (1988) Extinction and recolonization: their effects on the genetic differentiation of local populations. Evolution 42, 995-1005.

Wang X, Auler AS, Edwards RL, Cheng H, Cristalli PS, Smart PL, Richards DA, Shen CC (2004) Wet periods in northeastern Brazil over the past 210 kyr linked to distant climate anomalies. Nature 432, 740-3.

Waples RS, Gaggiotti O (2006) What is a population? An empirical evaluation of some genetic methods for identifying the number of gene pools and their degree of connectivity. Molecular Ecology, 15, 1419-1439. 
CAPÍtulo 5. The consequences of using the most polymorphic microsatellites on wild-mammals' genetic diversity estimates.

(em preparação)

\begin{abstract}
Genetic diversity is one of the most important estimates in conservation genetics. Usually, microsatellites are the markers of choice to estimate it, and they are selected based on its polymorphism in population / taxa of interest. However, the potential bias and the consequences of the a priori description and use of only the most polymorphic markers in estimating wild populations' genetic diversity were seldom addressed.

In this chapter we aimed to test if the use of just a few polymorphic loci would result in similar estimates as larger microsatellite batteries. Also we tested the consequences of selecting these loci based on different estimates of a locus' polymorphism level.

Particular interest was given to Bradypus sloth species. New data on the pygmy sloth ( $B$. pygmaeus) and its close relative common sloth's (B. variegatus) population were described. We also analyzed other mammalian microsatellite datasets already published and available online, to extend the results to other species. For each dataset, different subsets were created considering distinct locus' polymorphism levels (number of alleles, observed and expected heterozygosities), and varying the number of loci analyzed. For each subset, mean expected heterozygosity was estimated, as a measure of the populations' genetic diversity.

Among sloths, MU1 (southern Atlantic forest common sloth population) had the smallest genetic diversity estimates, even than the pygmy sloth. However, this species' population had lower estimates than its close relative, the Panamanian common sloth population. Signs of recent bottleneck were detected within the pygmy sloth population.

Among all mammalian datasets, irrespectively the polymorphism criteria and the number of loci used, the selection of the most polymorphic loci significantly overestimated $H s$, comparing to the same amount of randomly selected microsatellites. Ranking populations varied according to the number of loci and populations considered, given that $H s$ estimates were dependent on the locus' polymorphism in the dataset under analyses. This was most striking in highly structured and very genetically dissimilar populations. Genetic diversity estimates should be based on random sets of polymorphic microsatellites. Furthermore, for newly described markers, the publication of all loci genotyped is advisable, regardless their degree of polymorphism. Finally, wildlife managers must be aware of that ranking populations according to genetic diversity estimates will vary, depending on the amount of loci, their polymorphism and the populations being analyzed.
\end{abstract}




\section{Keywords}

Ascertainment bias - Bradypus - Canis lupus - Empirical data - Pan

\section{Introduction}

Genetic diversity is one of the most important estimates in conservation genetics (Lacy 1987; Frankham et al. 2002). Assessing genetic diversity levels can highlight endangered populations, with high inbreeding and possible reduced population fitness and viability (Frankham et al. 2002; Reed \& Frankham 2003; Markert et al. 2010). The correlation between genome-wide levels of genetic diversity and those described by microsatellites is debatable (Väli et al. 2008; Ljungqvist et al. 2010 and references therein), and single nucleotide polymorphism (SNP) are becoming a more important tool in this field of research (Seddon et al. 2005). Still, authors continue to describe current population genetic diversities through the analysis of microsatellites (Quéméré et al. 2010; Guerier et al. 2012; Kleven et al. 2012; Silva et al. Chapter 4).

Traditional de novo description of microsatellites has been done through microsatelliteenriched libraries, which can limit the number and the type of repetitive motif of the loci described (Ostrander et al. 1992; Hamilton et al. 1999). Usually, up to 20 polymorphic microsatellites per species are described in mammals (e.g. Garcia et al. 2005; Razafindrakoto et al. 2008; Røed et al. 2011). Currently, the availability of microsatellites is increased by highthroughput sequencing techniques, allowing de novo description of hundreds to thousands of microsatellites, even for non-model species (Castoe et al. 2012; Luo et al. 2012; Silva et al. Chapter 3). Another technique to describe genetic diversity in microsatellites is through crossspecies amplification. Genotyping shared-markers between different species is a common practice, either within the same genus or between species sharing higher taxonomic levels (reviewed by Barbará et al. 2007). However, cross-amplification can be affected by ascertainment bias. This bias is a consequence of the interruption of microsatellites' motif, their elimination, or even the occurrence of mutations within microsatellites' flanking regions throughout their evolution across different taxa. Ascertainment bias usually results in unsuccessful amplifications, and is accounted for by sequencing cross-amplified products or disregarding monomorphic markers within the cross-species (Ellegren et al. 1997; Hutter et al. 1998; Vowles \& Amos 2006). Cross-species microsatellites' amplification success and the amount of polymorphic loci are significantly variable among different taxa (reviewed by Barbará et al. 2007).

Despite the different methodologies and the increased easiness in the description of microsatellites, there are still restrictions on the number of markers genotyped. Especially in conservation genetics, monetary resources, and access to a substantial amount of DNA per sample are often limited, since non-invasive sampling is encouraged (e.g. Quéméré et al. 2010; Kleven et al. 2012). Koskinen et al. (2004) reviewed that most studies published before 2000 
used an average of six microsatellites, with the vast majority using only up to 10 markers. Currently, studies with a small number of microsatellite markers are still frequent (Quéméré et al. 2012; Mejía et al. 2011; Miotto et al. 2012), and the number 10 continues to be emphasized (e.g. Barbará et al. 2007). The routinely criteria to select microsatellites, among all the available ones, are mostly their level of polymorphism, and less often the easiness to amplify and genotype the loci (e.g. Heller et al. 2008; Nikolic et al. 2009). Even newly described markers are chosen focusing these criteria (Kleven et al. 2012).

The actual bias of selecting loci based on their polymorphism within species, and the consequences of the a priori description of the most polymorphic markers were seldom addressed. Hale et al. (2012) highlighted that smaller numbers of microsatellites loci lead to less precise genetic diversity estimates. Also, several coefficients of variation of genetic distances were differentially affected both by the number of markers, and their number of alleles (Kalinowski 2002; Koskinen et al. 2004). However, these studies analyzed only five to 32 microsatellites (Kalinowski 2002; Koskinen et al. 2004; Hale et al. 2012). Additionally, the use of only polymorphic markers in the detection of demographic changes was proved to decrease the power of some tests (Cornuet \& Luikart 1996; Beaumont 1999), and an advisable number of 5 to 20 polymorphic microsatellites was proposed to others (Luikart et al. 1998). Recently, a new software, SPOTG, has been proposed to define a priori the minimum number of samples and molecular markers for hybridization, temporal sampling, demography, connectivity and assignment studies (Hoban et al. 2013). Although helpful and insightful, as many other modelbased programs, simulations and studies, SPOTG depends on a considerable knowledge on species' and populations' evolutionary history. Assumed scenarios can depart considerably from reality, particularly for poorly known species, several of them endangered. Moreover, this software does not address the consequences of considering only the most polymorphic microsatellites within species.

Bradypus Linnaeus 1758 sloths are good examples of species whose poor knowledge on taxonomy, biological requirements, and behavior is still problematic. This lack of information affects least concerned to critically endangered species (Superina et al. 2010). Moreover, the description of polymorphic molecular markers for the evaluation of these species' genetic diversity has been challenging (Moraes-Barros, 2002, 2006; Silva et al. Chapters 3 and 4). Briefly, the common sloth Bradypus variegatus Schinz 1825 is a widespread neotropical mammal (Moraes-Barros et al. 2010). However, most comprehensive population genetics studies on this species were mainly conducted within Brazil and particularly within the Atlantic forest (AF). These analyses proposed species' management units (MU), highlighted the differentiation between Amazonian and AF populations, and evidenced the AF population structure (Moraes-Barros et al., 2006, 2007, 2011; Silva et al. Chapters 3 and 4). The most striking result was the uniqueness and depauperation of the genetic diversity of the AF 
southeastern MU, MU1 (Moraes-Barros et al., 2002, 2006, 2007; Silva et al. Chapters 3 and 4). We focused on de novo microsatellites' description within this population, both by traditional and high-throughput methodologies (Silva et al. Chapters 3 and 4). Within MU1, 19 (35.18\%) microsatellites were invariable, out of 54 species-specific polymorphic loci (Silva et al. Chapter 4). Among sloths, the pygmy sloth is restricted to one population, occurring only in Isla Escudo de Veráguas, Panama (Anderson \& Handley 2001, 2002). This critically endangered population has a well-known although short evolutionary history as a full species. The mainland Panamanian common sloth (PNM) is pointed out as the closer relative, from which the pygmy sloth is supposed to have derived by a vicariant and selective speciation process, about 9000 years ago (Anderson \& Handley 2001, 2002; Anderson et al. 2011). Interestingly, pygmy sloth's genetic diversity levels were very similar to estimates obtained from MU1/MU2 common sloth population (Silva et al. Chapter 3).

These evidences raised questions to the selection of smaller batteries of microsatellites i) Can we use just a few polymorphic loci, e.g. 10 as previous studies (Koskinen et al. 2004) or 20 as for Luikart's et al. 1998 demographic test) to compare genetic diversity estimates among different species/populations? ii) Can we select these markers based on their polymorphism? iii) Do these questions have similar answers among other mammal species?

\section{Material and methods}

\section{Sloth species}

We used Silva et al. (Chapter 4) common sloth populations' dataset, which includes five distinct populations, with very dissimilar levels of genetic diversity (Table 1; Moraes-Barros et al. 2007, 2011; Silva et al. Chapters 3 and 4), and complemented it by amplifying samples from PNM ( $\mathrm{n}=9)$, and from the pygmy sloth $(\mathrm{n}=10)$ on Silva's et al. (Chapter 4) microsatellites. Sampling, DNA extraction and markers amplification followed Silva et al. (Chapter 3).

Scoring errors, and evidences for allele dropout and null alleles within our new datasets were detected by Micro-Checker 2.2.3 (van Oosterhout et al. 2004). The test was performed running $10^{4}$ randomizations, ignoring missing data and considering $\alpha=0.05$. Departure from HardyWeinberg and linkage disequilibrium was tested for each locus in Arlequin 3.11 (Excoffier et al. 2005).

Inbreeding coefficients were estimated for all sloth populations to facilitate comparison between them. Estimates were calculated in Arlequin 3.11, under default settings (Excoffier et al. 2005). Moment-based methods implemented in Bottleneck 1.2.02 were used to test pygmy sloth demographic size changes (Luikart et al. 1998). Demographic tests were run considering a TPM with a variance among multiple steps of 12 or 30 , and a proportion of single-step mutations of $95 \%$ or $70 \%$, respectively (Piry et al. 1999; Givens et al. 2007). 


\section{Other mammalian datasets}

We added to the sloths' analyses different mammalian microsatellite datasets already published and available online (Table 1). The primates dataset included a bonobo Pan paniscus Schwarz 1929 population, and three populations/subspecies of the common chimpanzee $P$. troglodytes Blumenbach, 1799 (western P. troglodytes verus Schwarz, 1934, central P. $t$. troglodytes Blumenbach, 1799, and eastern P. t. schweinfurthii Giglioli, 1872; Becquet et al. 2007). The canids dataset included Iberian wolf Canis lupus signatus Cabrera 1907 and domestic dog C. l. familiaris Linnaeus 1758 populations (Godinho et al. 2011).

Bonobos are limited to the central region of the Democratic Republic of the Congo. Chimpanzees have a wider distribution, but it is disrupted in two fractions: roughly one from Guinea to Ghana (western population) and another from Cameroon, Gabon and Congo (central population) to Central African Republic, eastern Democratic Republic of the Congo to the border of Uganda (eastern population). Both primates are considered to be currently endangered (Fruth et al. 2008; Oates et al. 2008). First evaluations of bonobos' genetic diversity relied in 28 microsatellites (Reinartz et al. 2000). However, comparisons between bonobos' and chimpanzees' genetic diversities were limited to an eight microsatellites battery, and gave inconsistent results (Reinartz et al. 2000). Following analyses increased the number of molecular markers to more than 300 (Becquet et al. 2007). The different sampling strategies hinder the evaluation of the performance of the different microsatellite batteries used (Reinartz et al. 2000; Becquet et al. 2007).

The Iberian wolf is restricted to the northern Iberian Peninsula in Europe, constituting an isolated population. Wolves are not threatened as species, but the Iberian wolf is considered endangered in Portugal and vulnerable in Spain (Cabral et al. 2005; Mech \& Boitani 2010). Iberian wolves' genetic diversity was only recently comprehensively evaluated for the first time (Godinho et al. 2011). Curiously, this population had smaller levels of genetic diversity than the coexisting domestic dogs' sampled, and hybridization was detected among both subspecies. These evidences led authors to propose beneficial consequences from the hybridization, representing dogs' population as genetic diversity source for the wolves' population (Godinho et al. 2011). So we included this domestic population in our analyses.

These mammals, including sloths, are good models for evaluating the consequences of choosing the most polymorphic microsatellites on comparative studies of genetic diversity. This evaluation can be performed at different phylogenetic and taxonomic levels, since these datasets include comparisons between distinct populations, subspecies, and species, differentiated for distinct times. The sloth species analyzed differentiated only recently (Anderson \& Handley, 2001, 2002); primates have a more ancient divergence (Becquet et al. 2007), and the canids belong to the same species. Furthermore, sloths are interesting models to evaluate molecular markers use, because they are slow-evolving mammals, with lower than average mutation rates 
(Delsuc et al. 2004; Moraes-Barros et al. 2011). Almost all populations analyzed need precise genetic diversity estimates, since human disturbances, hunting, habitat loss and fragmentation, are menacing and decreasing these particular populations in their areas of occupancy (IUCN 2012).

Table 1. Number of polymorphic markers analyzed in each population studied, corresponding standard diversity indices (upper row) and standard deviations (lower row). Bp - Bradypus pygmaeus; Bv - B. variegatus; PNM - Panama; MU - management unit; AMZWest and AMZ East - western and eastern Amazonia, respectively; Pp - Pan paniscus; PttC - P. troglodytes troglodytes, Central population; PtsE P. t. schweinfurthii, Eastern population; PtvW - P. t. verus, Western population; Clf - Canis lupus familiaris; Cls - C. l. signatus;.

\begin{tabular}{|c|c|c|c|c|c|c|c|}
\hline & & No.M & No.G & A & Ho & Hs & $\mathrm{Ar}$ \\
\hline \multirow{14}{*}{$\frac{\mathfrak{3}}{3}$} & \multirow{2}{*}{$\mathrm{Bp}$} & \multirow{2}{*}{$24(45)$} & 19.83 & 2.625 & 0.4815 & 0.4564 & 11.63 \\
\hline & & & 0.5650 & 0.8750 & 0.2508 & 0.2190 & 7.631 \\
\hline & \multirow{2}{*}{ BvPNM } & \multirow{2}{*}{$36(45)$} & 17.33 & 4.583 & 0.6117 & 0.6468 & 17.64 \\
\hline & & & 1.656 & 1.826 & 0.2974 & 0.2199 & 9.894 \\
\hline & \multirow{2}{*}{ BvAMZWest } & \multirow{2}{*}{$43(45)$} & 9.070 & 4.442 & 0.6423 & 0.7674 & 19.14 \\
\hline & & & 1.534 & 1.278 & 0.2682 & 0.1716 & 11.90 \\
\hline & \multirow{2}{*}{ BvAMZEast } & \multirow{2}{*}{$39(45)$} & 13.39 & 4.000 & 0.5783 & 0.6216 & 14.95 \\
\hline & & & 1.138 & 1.522 & 0.2678 & 0.1982 & 14.97 \\
\hline & \multirow{2}{*}{ BvMU3 } & \multirow{2}{*}{$43(45)$} & 38.14 & 3.930 & 0.4332 & 0.5283 & 12.63 \\
\hline & & & 4.647 & 1.724 & 0.2146 & 0.2306 & 8.882 \\
\hline & \multirow{2}{*}{ BvMU2 } & \multirow{2}{*}{$38(45)$} & 31.79 & 3.763 & 0.4233 & 0.5110 & 11.58 \\
\hline & & & 0.7770 & 1.979 & 0.2091 & 0.2292 & 10.12 \\
\hline & \multirow{2}{*}{ BvMU1 } & \multirow{2}{*}{$35(45)$} & 46.97 & 2.514 & 0.3308 & 0.3700 & 6.800 \\
\hline & & & 4.069 & 0.8530 & 0.1903 & 0.2018 & 5.263 \\
\hline \multirow{8}{*}{$\tilde{\Xi}$} & \multirow{2}{*}{$\mathrm{Pp}$} & \multirow{2}{*}{$261(291)$} & 11.81 & 4.651 & 0.7070 & 0.7251 & 17.72 \\
\hline & & & 0.8100 & 1.631 & 0.2436 & 0.1758 & 11.03 \\
\hline & \multirow{2}{*}{$\mathrm{PttC}$} & \multirow{2}{*}{$283(291)$} & 31.01 & 7.682 & 0.7258 & 0.7678 & 27.039 \\
\hline & & & 1.809 & 2.814 & 0.1873 & 0.1611 & 12.630 \\
\hline & \multirow{2}{*}{ PtsE } & \multirow{2}{*}{$273(291)$} & 9.187 & 4.216 & 0.6760 & 0.7334 & 17.465 \\
\hline & & & 1.662 & 1.463 & 0.2540 & 0.1786 & 11.099 \\
\hline & \multirow{2}{*}{ PtvW } & \multirow{2}{*}{277 (291) } & 93.31 & 6.653 & 0.6406 & 0.6589 & 21.621 \\
\hline & & & 4.544 & 2.760 & 0.2068 & 0.1978 & 10.552 \\
\hline \multirow{4}{*}{ 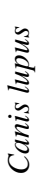 } & \multirow{2}{*}{ Clf } & \multirow{2}{*}{$43(43)$} & 334.8 & 8.744 & 0.6760 & 0.7603 & 21.88 \\
\hline & & & 88.91 & 3.586 & 0.0908 & 0.0847 & 13.85 \\
\hline & \multirow{2}{*}{ Cls } & \multirow{2}{*}{$43(43)$} & 357.1 & 6.349 & 0.5380 & 0.6192 & 17.65 \\
\hline & & & 69.46 & 2.802 & 0.1785 & 0.2009 & 10.25 \\
\hline
\end{tabular}

No.M - number of polymorphic loci (total number of loci)

No.G - mean number of gene copies

A - mean number of alleles

Ho - mean observed heterozygosity

Hs - mean expected heterozygosity

$\mathrm{Ar}$ - Allelic range 


\section{Subsets analyses}

Original datasets were reduced to include only autosomal markers and no hybrid individuals (Becquet's et al. 2007; Godinho's et al. 2011). The new datasets were primarily characterized by estimating genetic indices for each population in Arlequin 3.11 (Excoffier et al. 2005; Table 1).

Further analyses were performed at three not-exclusive levels: taxonomic, loci number, and locus level of polymorphism. Therefore, datasets were divided in subsets observing these levels. Overall, taxa and population subsets focused the genetic diversity estimates on different taxonomic levels. Overall datasets compared genetic diversity among all populations within datasets. Taxa subsets included only the common sloth populations. Population subsets considered each population individually. Primates' and canids' overall subsets considered all microsatellites available for each. Sloths' overall subsets only analyzed loci simultaneously polymorphic on both species, to account for ascertainment bias (Ellegren et al. 1997; Hutter et al. 1998; Vowles \& Amos 2006). Population subsets considered a microsatellite as polymorphic if it had two or more alleles within the population analyzed, irrespectively the locus' number of alleles in the other populations. Loci with allele frequencies lower than 5\% were also considered.

Determined subsets were constituted by selecting loci according to their polymorphism level. Loci polymorphism level was measured separately by three commonly used genetic diversity indices, namely the number of alleles $(A)$, the observed $(\mathrm{Ho})$ and the expected heterozygosity $\mathrm{He}$ ) for each locus. Determined subsets were compared against the random subsets, which comprised the same amount of randomly selected loci.

Within subsets, the number of loci analyzed started as ten (as for ten is the most frequently used number of microsatellites, Koskinen et al. 2004), and subsequently ten more were added, until all available markers were included in the analysis.

For each subset the mean population genetic diversity was estimated by the mean expected heterozygosity as computed in Adegenet $\mathrm{R}$ package (Jombart 2008). Mean expected heterozygosity was named as $H s$ to differentiate from the locus expected heterozygosity, $\mathrm{He}$. Jombart's (2008) Hs is slightly different from Excoffier's et al. (2005), since it does not consider the number of samples genotyped. No comparisons were made between the two. Random subsets were created by random subsampling loci, without replacement, repeatedly over 3000 iterations. Random subsets generated sampling distributions and statistics to $H s$, to be compared against the corresponding $H s$ from the determined subsets (a similar procedure was used by Reinartz et al. 2000). These calculations were performed in R 2.15.1, using R basic functions (R Development Core Team 2008), and functions from adegenet and gtools packages (Jombart 2008; Warnes et al. 2010). 


\section{Results}

\section{Sloth species}

Fifty microsatellites were successfully amplified and cross-amplified within PNM common sloth and pygmy sloth populations, respectively. Yet, for the total 19 samples, two loci (TT36 and TT111) had alleles out of the expected size variation, and were eliminated from the analyses. Silva et al. (Chapter 4) reported the same problem in Amazonian populations, and in another marker (TT57). These loci should be sequenced to understand if mutation occurred in the flanking region or within the microsatellite repeat, but for the purpose of our analyses we eliminated the three. The previously reported monomorphic loci were also monomorphic within these populations (TT92 and TT47). From the remaining 45, correspondingly, 12 and 24 microsatellites were also invariable for the PNM and pygmy sloth populations (Table 1).

No evidences for scoring errors due to stuttering, large allele dropout, and null alleles were detected. Likewise, no consistent departures from Hardy-Weinberg equilibrium and linkage disequilibrium were found.

Inbreeding estimates are depicted in Table 2. Fis computation only considers polymorphic loci, within populations (Excoffier et al. 1992). Panamanian populations had no signs of inbreeding, although the results were not statistically different from the random value in both cases. In all the other populations, the number of polymorphic markers increased from the overall (24 loci) to the taxa (45 loci) subsets. Consequently, Fis indices varied in almost all populations, resulting in distinct significance levels and inbreeding trends between the taxa and overall subsets.

Table 2. Bradypus populations' specific Fis indices considering taxa and overall datasets ( $p$-values calculated considering random Fis $\geq$ observed Fis over 10100 permutations; Excoffier et al. 1992). Bp Bradypus pygmaeus; $\mathrm{Bv}$ - B. variegatus; PNM - Panama; MU - management unit (according with Silva et al. Chapter 4); AMZWest and AMZ East - western and eastern Amazonia, respectively.

\begin{tabular}{ccccc} 
& \multicolumn{2}{c}{ Taxa } & \multicolumn{2}{c}{ Overall } \\
& Fis & $p$-value & Fis & $p$-value \\
\hline Bp & & & -0.1436 & 0.9386 \\
BvPNM & 0.0066 & 0.4763 & -0.0497 & 0.8403 \\
BvAMZWest & 0.1004 & 0.0735 & 0.0536 & 0.1769 \\
BvAMZEast & -0.0156 & 0.5779 & 0.0180 & 0.4201 \\
BvMU3 & 0.1046 & 0.0026 & 0.0697 & 0.0535 \\
BvMU2 & 0.1651 & 0.0001 & 0.1602 & 0.0011 \\
BvMU1 & 0.1087 & 0.0132 & 0.1039 & 0.0276 \\
\hline
\end{tabular}

Wilcoxon test detected a bottleneck event in the pygmy sloth population, under the TPM model with lower single step mutations probability (one-tailed test for heterozygosity excess 
$p=0.03690$ for variance $=30$ and SMM probability $=70 \% ; p=0.10911$ for variance $=12$ and SMM probability $=95 \%$ ). Mode-shift test also detected a change in the alleles' frequency distribution within the population.

\section{Subsets analyses}

We analyzed 13 populations from five different species, grouped within three datasets. Total datasets varied between 43 (dogs and Iberian wolves) and 291 microsatellites (primates; Table 1). The number of polymorphic microsatellites within populations varied between 24 and 283 , for the pygmy sloth and central chimpanzee populations, respectively (Table 1). The total number of individuals analyzed was also different, varying between five (eastern chimpanzee and western Amazonian common sloth (AMZWest) populations) and 205 (Iberian wolf population).

Among sloths, the common sloth MU1 has the lowest genetic diversity and AMZWest the highest (taxa subset; Fig. 1A). The rank of the other populations varied with the number of loci and the polymorphism level criteria used. Accounting for ascertainment bias and including the pygmy sloth population changes the results (overall subset; Fig. 1B). Ranking becomes more stable across different analyses, and PNM population becomes the population with the highest genetic diversity. However, MU1 continues to have the lowest genetic diversity, even than the pygmy sloth.

Within primates, tests were performed every 10 loci added as for the two other datasets, but given the larger amount of loci, with depicted results from 10 to 50 loci, and then every 50 loci added until the total amount of markers is used (Figs. 2, 3B). Levels of genetic diversity among primates are very similar, but the central population stands out from the others, and has the highest genetic diversity (Table 1, Fig. 2A). Among eastern and western chimpanzees and bonobos, differences between $H s$ estimates also varied not only in magnitude, but also in ranking populations, particularly for bonobo's. For most $H s$ computations, this population presented the smallest $H s$ indices among the primates analyzed. A different result was obtained with six Ho subsets. For those subsets analyzing 10-100 loci with the highest Ho, bonobo's population had higher genetic diversity than the eastern population.

As for the canids, regardless the amount of microsatellites analyzed, dogs had always higher genetic diversity than the Iberian wolf populations (Fig. 2B). However, as detected in the other datasets (Fig. 1A, 1B, 2A), this difference varied. Dogs had between 1.26-fold higher $H s$ estimates than wolves (10 loci with the highest $A$ in the overall subset) to virtually similar levels of genetic diversity (1.04-fold; 10 loci with the highest $H o$ in the overall subset).

As expected, the selection of the most polymorphic loci resulted in higher estimates of the genetic diversities when smaller numbers of loci were chosen. This is evident in all subsets (taxa, population and overall), and in all polymorphism criteria analyzed ( $\mathrm{A}, \mathrm{Ho}$ and $\mathrm{He}$; Figs. 1 
- 2). Differences between the $H s$ estimated with the total number of loci varied up to 0.54-fold (10 loci with the highest $\mathrm{He}$ within MU1 in the taxa dataset; Fig. 1A). Nevertheless, population subsets were depicted in Fig. 3 to better evidence this effect on each population individually (Fig. 3).

A)
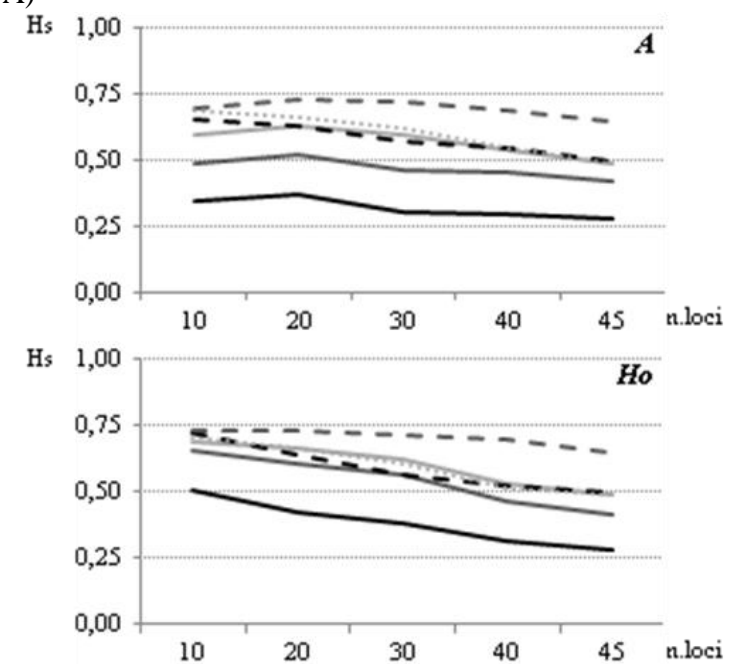

Hs 1

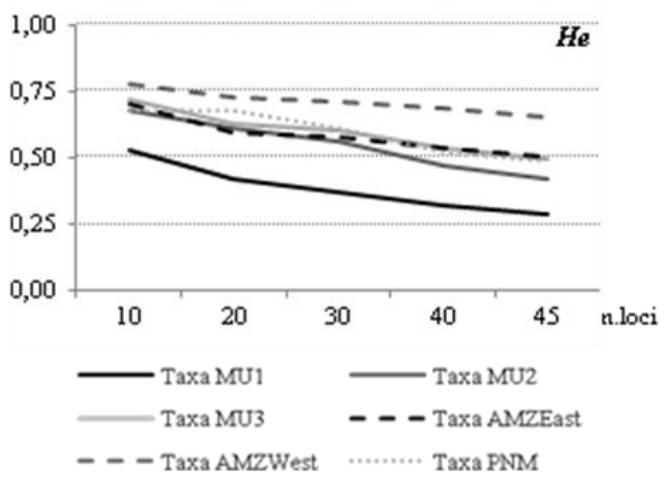

B)
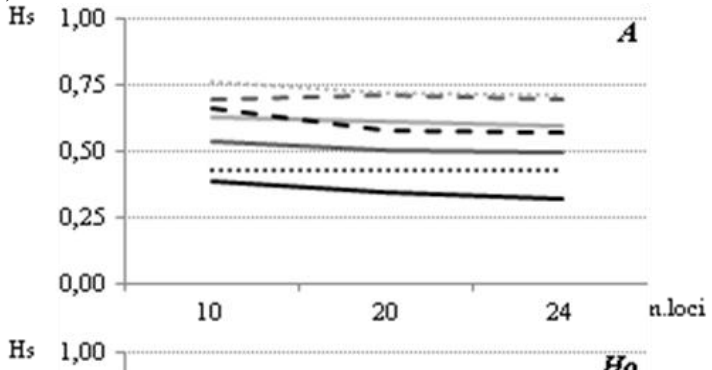

Ho

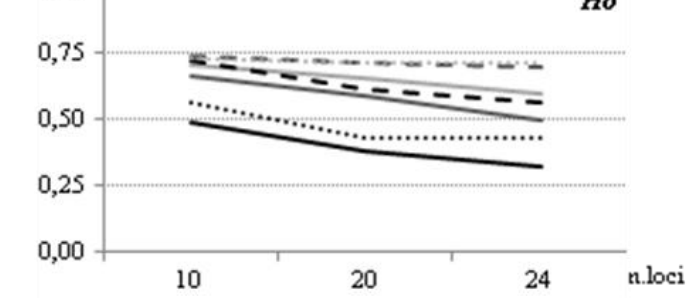

Hs 1,00 He

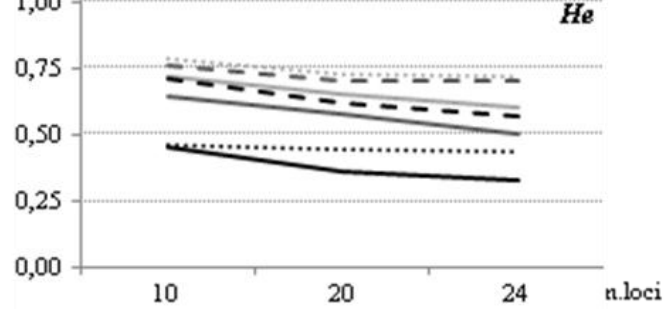

- Overall MU3 - - - Overall AMZEast

- - - Overall AMZWest. .......... Overall PND

......... Overall Bp

Figure 1. Averaged expected heterozygosity $(H s)$ after the determined selection of loci considering the number of alleles $(A)$, observed heterozygosity $(\mathrm{Ho})$ and expected heterozygosity $(\mathrm{He})$. A) Sloths' taxa and B) overall subsets' estimates. Taxa subset considered as polymorphic, the variable loci in the total common sloth's dataset; Overall subset considered loci concomitantly polymorphic within the pygmy sloth population and in common sloths populations' altogether; Common sloth populations: MU management unit; AMZWest - Western Amazonia; AMZEast - Eastern Amazonia; PNM - Panama. Bp Bradypus pygmaeus.

In fact, either using $\mathrm{Ho}, \mathrm{He}$ or $\mathrm{A}$, the determined choice of markers resulted in significant overestimation of the genetic diversity. In total, we had 180 (sloths), 216 (primates), and 48 (canids) determined subsets. Among them, considering $\alpha=0.05$ or $\alpha=0.001$ respectively, $67.11 \%$ to $55.56 \%$ (sloths), $98.61 \%$ to $95.37 \%$ (primates), and $87.50 \%$ to $62.50 \%$ (canids) corresponded to significant $H s$ overestimations, against the respective random subset. This overestimation seemed to be independent from the amount of loci used (Supplementary Material S1). Nonetheless, the highest frequency of $H s$ overestimates occurred within the population subsets (Fig. 3). Likewise the highest estimates were obtained with these subsets, which included only 
polymorphic markers within each population analyzed individually. Polymorphism biases were more accentuated in populations with the lowest genetic diversity.

A)

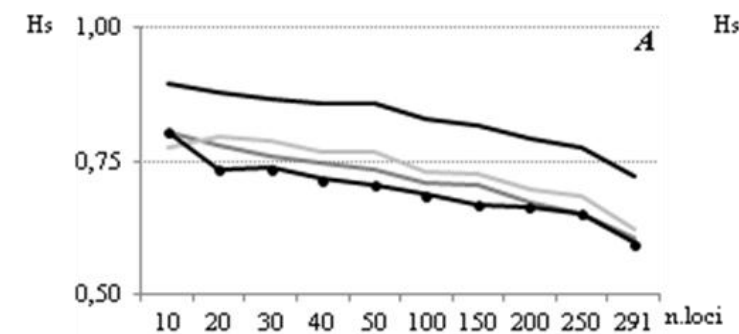

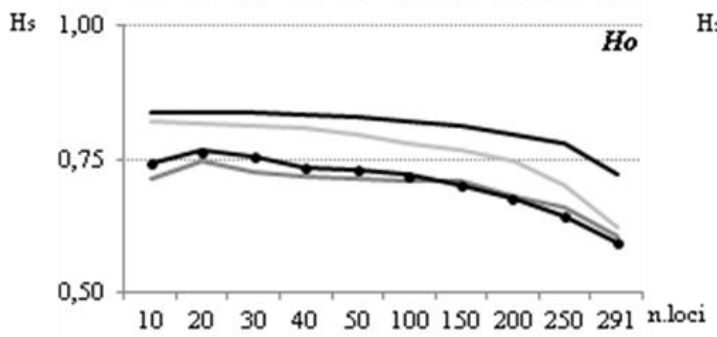
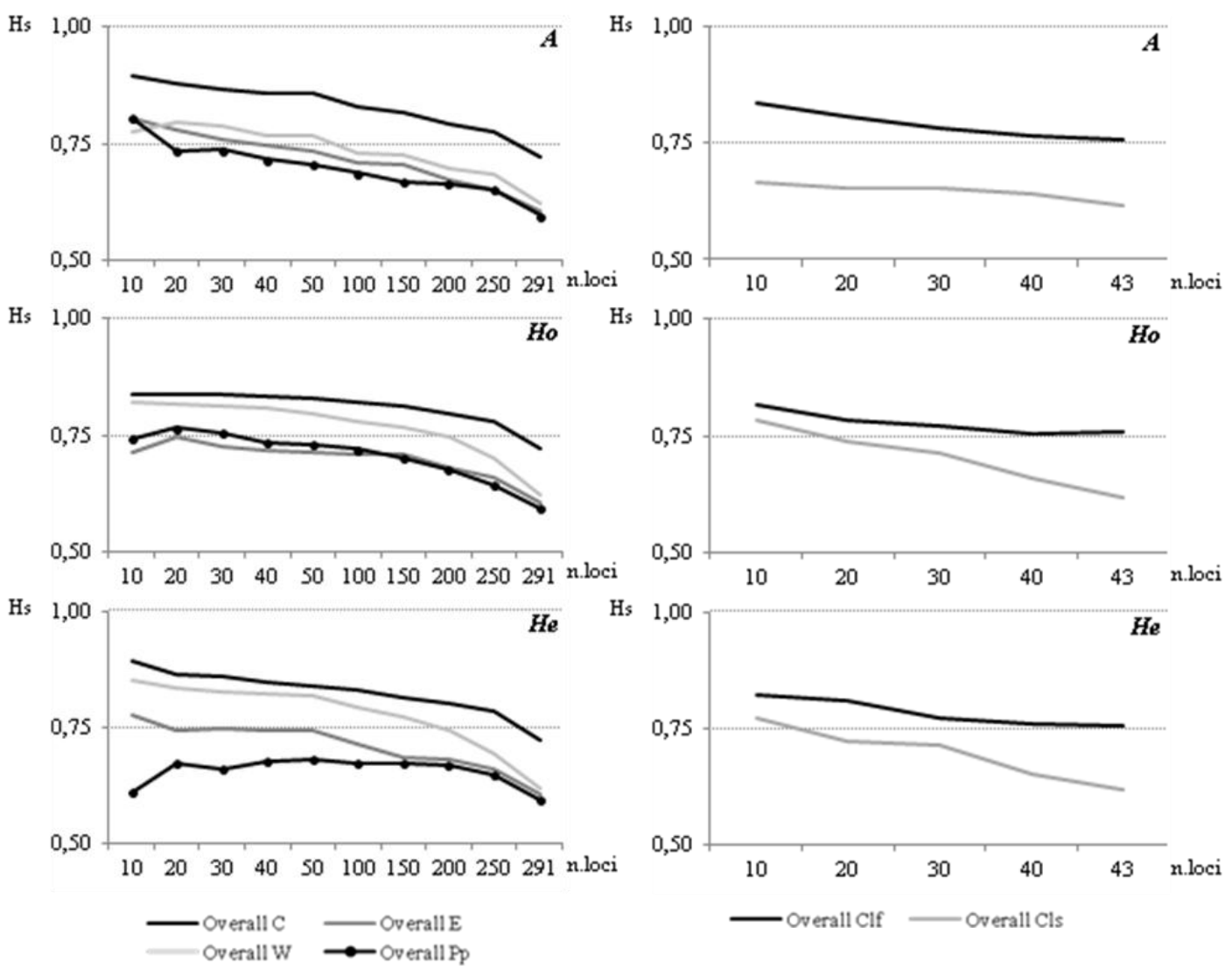

Figure 2. Averaged expected heterozygosity $(H s)$ after the determined selection of loci considering the number of alleles $(\mathrm{A})$, observed heterozygosity $(\mathrm{Ho})$ and expected heterozygosity $(\mathrm{He})$. Overall subsets considered the polymorphic loci in the total datasets. A) Primates (Chimpanzee's populations: C Central; E - Eastern; W - Western. Pp - Pan paniscus) and B) Canids (Clf - Canis lupus familiaris; Cls C. l. signatus).

\section{Discussion}

\section{Sloth species}

According with Barbará et al. (2007) review, it is expected that about $80 \%$ of cross-species microsatellites amplification would be successful between mammal-species within the same genus, and among these, 70\% would correspond to polymorphic loci. Successful amplifications of the common sloth loci in the pygmy sloth population were close to the averaged (88.9\%), but the number of polymorphic loci was far lower than the expectation (50\%). PNM population had a $70 \%$ success of amplification, and $75 \%$ of polymorphic loci. Both populations had exactly the same amplification success (the same loci effectively amplified in both), but polymorphism sharing was reduced to $66.7 \%$, between Central American populations. These results might 
indicate that ascertainment bias is possibly affecting both the pygmy sloth and PNM populations', in relation to the Brazilian ones. Firstly, the common sloth taxonomy is considered unsolved (Chiarello et al. 2011). The geographic distance between PNM and Brazilian populations could account for a considerable populations' differentiation. Homoplasy might also be affecting the results (Estoup et al. 2002). Secondly, genetics and morphology are extremely variable within the common sloth species (Moraes-Barros et al. 2011, and pers. comm.). In other words, although more studies are needed, we conclude that ascertainment bias between the pygmy sloth and the PNM populations would be ignored. Conversely the ascertainment bias between these populations and the Brazilian ones should be considered as the main possibility. Thus, genetic diversity comparisons between Panamanian and Brazilian populations should be limited to the overall subset (Fig. 1B). The 24 loci that are polymorphic within the pygmy sloth are also polymorphic within the PNM population. This option also implies that, within sloths' taxa subset, only direct comparisons among the Brazilian populations can be considered unbiased (Fig. 1A).

For the first time we compared the genetic diversity between the pygmy sloth population and its putative population of origin. The Panamanian common sloth (PNM) population's genetic diversity was unambiguously higher than the pygmy sloth's: 0.713 and 0.433 (24 loci), respectively. PNM $H s$ values were 1.30-fold (10 loci with the highest $H o$ ) to 1.78 -fold higher (10 loci with highest $A$ ) than the pygmy sloth population's. The genetic diversity loss within the pygmy sloth's population was likely the result of a bottleneck event, as detected by a shifted mode on the distribution of allele frequencies. This test is particularly suitable to estimate population decreases in the last 250 to 500 years, considering the six years of generation time for sloths (Luikart et al. 1998; Anderson \& Handley 2002). Recent logging on the Isla Escudo de Veráguas (testified by Kaviar et al. 2012) might be negatively affecting the pygmy sloth population. Nevertheless, the other moment-based method, that can detect not so recent events, also detected a bottleneck (Piry et al. 1999). So, we cannot exclude the possibility that other events, such as the insular nature of this species and its suggested recent origin (Anderson \& Handley 2001, 2002), might also have influenced the result. The power of the demographic tests might have been also compromised by the use of the minimum number of samples (10) recommended (Piry et al. 1999). 
A)
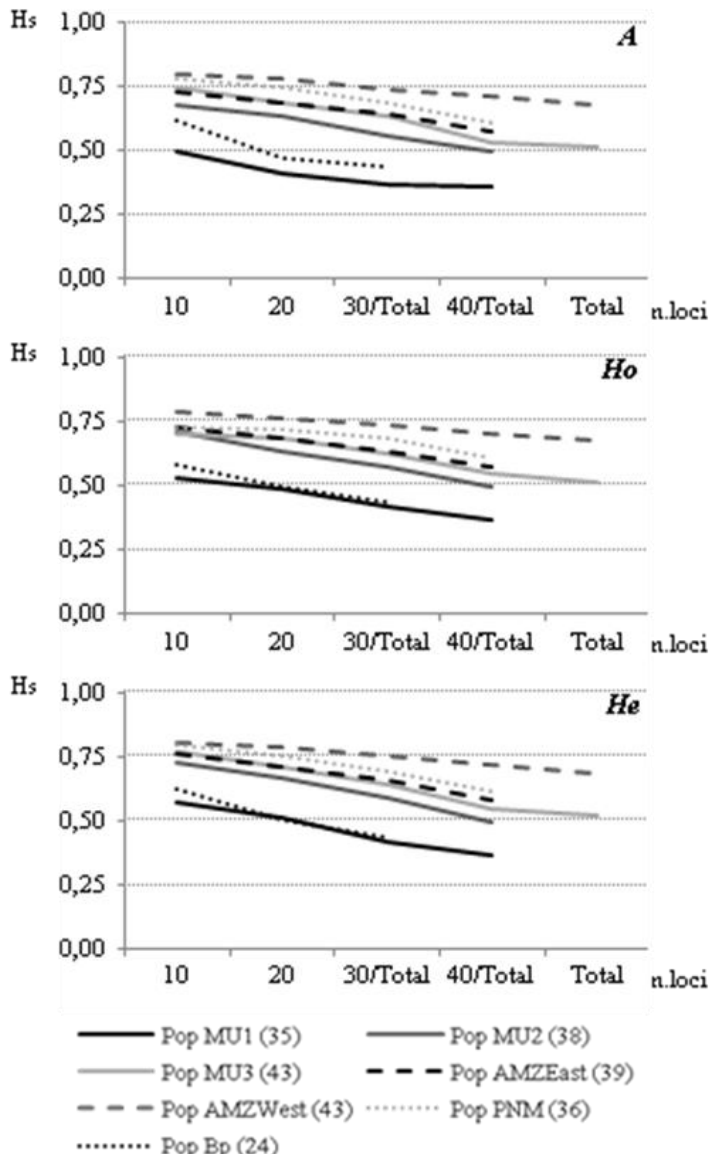

B)
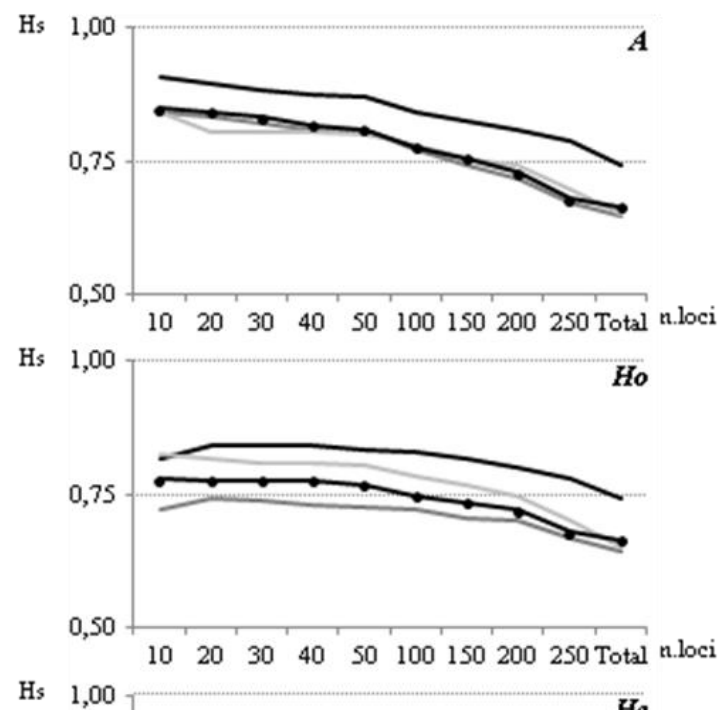

He

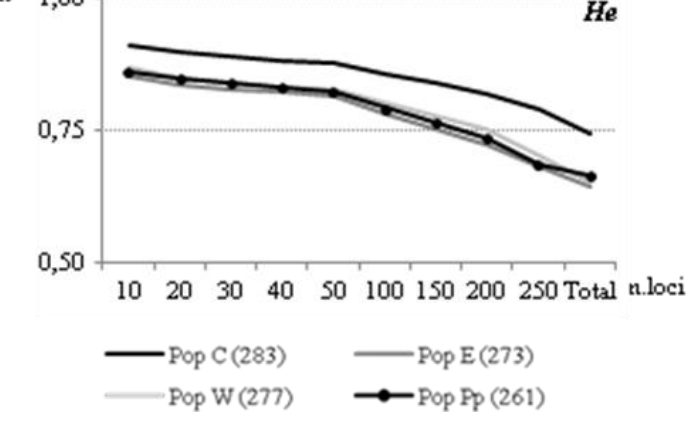

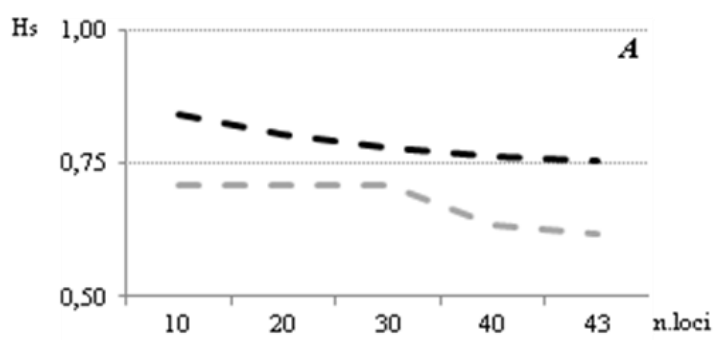
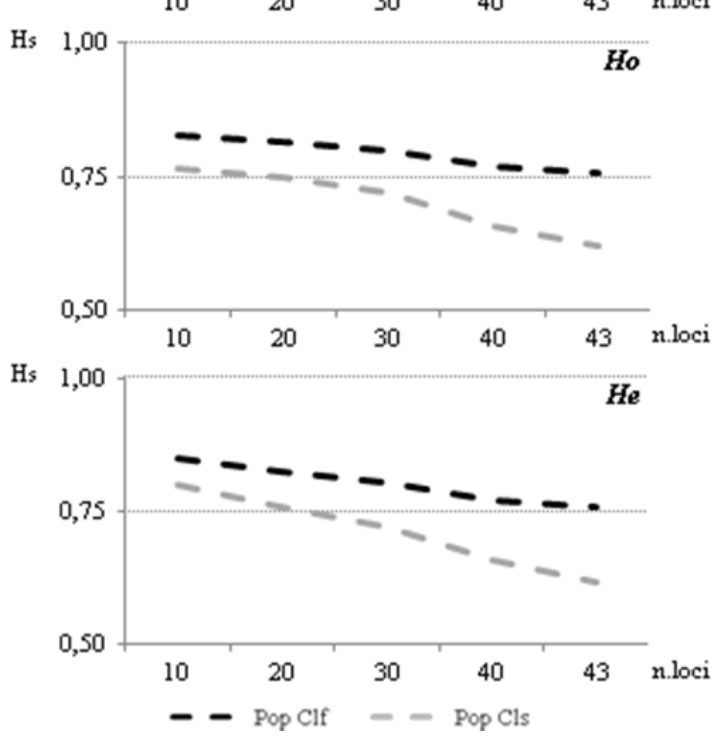

Figure 3. Averaged expected heterozygosity $(H s)$ after the determined selection of loci considering the number of alleles $(A)$, observed heterozygosity $(H o)$ and expected heterozygosity $(\mathrm{He})$. Population subsets regard polymorphism within each population separately. Total number of loci analyzed for echa population in brackets. A) Sloths (Common sloth populations: MU - management unit; AMZWest - Western Amazonia; AMZEast - Eastern Amazonia; PNM - Panama. Bp - Bradypus pygmaeus). B) Primates (C - P. troglodytes troglodytes, Central population; E - P. t. schweinfurthii, Eastern population; W - P. t. verus, Western population; Pp - Pan paniscus). C) Canids (Clf - Canis lupus familiaris; Cls - C. l. signatus). 
Previous genetic analyses of sloths' populations described similar genetic diversity levels between MU1+MU2 and the pygmy sloth, both at nuclear and mtDNA levels (Silva et al. Chapter3; Moraes-Barros, pers. comm.). Irrespectively the amount of markers used (10, 20 or 24 - overall subset), and the polymorphism criteria used for loci selection, MU2 had always higher genetic diversity than the pygmy sloth and the MU1 populations (Fig. 1B; see also Table 1). Among Brazilian common sloth populations, considering the taxa subset (45 loci), MU1 still had the lowest $H s$ estimates, being about 0.62 -fold less diverse than MU2, and 0.42-fold than AMZWest, the population with highest genetic diversity (Fig. 1A). All subsets are in agreement with previous data that evidenced the lower genetic diversity of MU1 populations, among the sloth populations studied so far (Moraes-Barros et al. 2002, 2006, 2007; Lara-Ruiz et al. 2008; Silva et al. Chapters 3 and 4).

\section{Subsets analyses}

The number of datasets available in the literature limited our analyses. Still, we preferred to analyze real data rather than simulated, because simulations generally consider evolutionary models that depart from reality. Also, simulation algorithms require prior knowledge that is too imprecise or even nonexistent for many species (see e.g. Carvajal-Rodríguez review 2008).

Our analyses of mammalian empirical datasets highlight that the determined choice of the polymorphic markers is significantly biased from the random selection of the same amount of microsatellites, irrespectively the criteria of loci selection. All the analyses reported emphasize that the random selection of polymorphic markers is preferable to the a priori selection of the most polymorphic loci. From a half (sloths) to almost all (primates) $H s$ estimates calculated with the determined subsets resulted in overestimations of the random selection of the same amount of loci. This result is intuitive, but no test had been formally performed, and the selection of loci according to their degree of polymorphism is a routine, even for estimation of wild populations' genetic diversity in conservation contexts (Heller et al. 2008; Nikolic et al. 2009; Kleven et al. 2012). One of the most important consequences of selecting the most polymorphic loci within a dataset is that rankings and magnitudes of pairwise comparisons between populations are dependent on the populations being analyzed, and so different results can be obtained. The two subsets used to compare sloth populations (taxa - five populations of the same species, disregarding PNM; and overall - the same five plus two other, including at least one from a different species), illustrates the best this observation (Fig. 1). These results highlight that the knowledge on the evolutionary history of populations/species, meaning the amount of populations or close species known or under analyses, can affect tremendously our evaluation on populations' genetic diversity. Shared evolutionary history, but also population structure, population differentiation, and the amount of loci available influenced $H s$ estimates, making it more prone to vary with the distinct subsets analyzed. 
Thus, also as expected, genetic diversity estimates varied with the amount of molecular markers used. In general, higher estimates were obtained with smaller number of markers, given that the most polymorphic were selected. However, comparisons of $H s$ between populations had particularly distinct results, both hierarchically and quantitatively, and especially for batteries of 10, 20 or 30 loci (Fig. 1, 2). A minimum threshold of 40 loci seems to assure better comparative analyses of genetic diversity among wild-mammals' populations. Populations with similar genetic diversity estimates will always be tricky to rank, as shown by primates' analyses. The 291 loci herein analyzed ranked populations differently from Becquet's et al. (2007) total dataset. Nevertheless, we agree that more robust estimates are gained by increasing the number of molecular markers (Kalinowski 2002; Koskinen et al. 2004; Hale et al. 2012).

Accounting these limitations on the genetic diversity estimates and comparisons between populations is particularly important when prioritizing conservation and management actions are needed. Our decisions can be numerous, regarding the different approaches: different taxa, different amounts of loci, different degrees of loci polymorphism. Comparative evaluations of genetic diversity levels must be done with caution, and accounting all information available, as much as possible. Conservation actions need to be flexible and easily updated. Scientific research must be grounded in a dynamic interface with operational conservation (such as the successful example of the recovery of the black footed ferret, Biggins et al. 2011).

Finally, we advise the publication of all microsatellites described within target species, regardless their degree of polymorphism. Distinct populations / taxa can present very dissimilar polymorphism levels at distinct loci. This is most striking in highly structured and very dissimilar populations such as the common sloth, for which microsatellite-based differentiation indices can be quite high (e.g. Fst $=0.61$; Silva et al. Chapters 3 and 4), and polymorphism of a locus can vary from fully monomorphic in a population (MU1) to eight alleles in another (MU3; TT111; Silva et al. Chapter 4).

\section{Conclusions}

Cross-species amplification of microsatellites between the common sloth and the pygmy sloth is possibly affected by ascertainment bias. However, the 24 polymorphic loci available led us to conclude that the PNM population has higher genetic diversity than the pygmy sloth, its close relative. Furthermore, it seems likely that the common sloth MU1 has the lowest genetic diversity of all the sloth populations studied so far.

Nevertheless, relative comparisons of genetic diversity between mammalian populations and species might be misleading when a small amount $(<40)$ of microsatellites is used. Namely the magnitude, and the hierarchy of the pairwise genetic diversity differences might be compromised. Furthermore, the selection of microsatellites based on their polymorphism, either measured by the number of alleles, the observed or the expected heterozygosities, have a 
considerable influence on the estimation of the wild populations' genetic diversity, rather than the number of loci used. The knowledge on the evolutionary history of a taxon also influences genetic diversity estimates by focusing the analyses in distinct groups of interest.

We recommend that genetic diversity comparative analyses should be performed with a stepby-step detailing, and with randomly selected polymorphic microsatellites rather than considering the most polymorphic within one or several taxa.

\section{Acknowledgments}

I would like to acknowledge the several discussions on this theme, and endless patience of LABEC-USP and CIBIO/CTM-UP staffs, particularly Camila Clozato, Nadia de Moraes-Barros and Teresa Silva.

\section{References}

Anderson, R.P. \& Handley, C.O. (2001) A new species of three-toed sloth (Mammalia: Xenarthra) from Panama, with a review of the genus Bradypus. Proceedings of the Biological Society of Washington, 114, 1-33.

Anderson, R.P. \& Handley, C.O. (2002) Dwarfism in insular sloths: biogeography, selection, and evolutionary rate. Evolution, 56, 1045-1058.

Anderson, R., Moraes-Barros, N. \& Voirin, B. (2011) Bradypus pygmaeus. In: IUCN 2012. IUCN Red List of Threatened Species. Version 2012.2. www.iucnredlist.org. Downloaded on 20 April 2013.

Barbará, T., Palma-Silva, C., Paggi, G.M., Bered, F., Fay, M.F. \& Lexer, C. (2007) Crossspecies transfer of nuclear microsatellite markers: potential and limitations. Molecular Ecology, $16,3759-3767$.

Biggins, D.E., Livieri, T.M. \& Breck, S.W. (2011) Interface between black-footed ferret research and operational conservation. Journal of Mammalogy, 92, 699-704.

Beaumont, M.A. (1999) Detecting population expansion and decline using microsatellites. Genetics, 153, 2013-2029.

Becquet, C., Patterson, N., Stone, A.C., Przeworski, M. \& Reich, D. (2007) Genetic structure of chimpanzee populations. PLoS Genetics, 3, e66.

Cabral, M.J., Almeida, J., Almeida, P.R., Dellinger, T., Ferrand de Almeida, N., Oliveira, M.E., Palmeirim, J.M., Queiroz, A.I., Rogado, L., Santos-Reis, M. (2005) Livro Vermelho dos Vertebrados de Portugal. Instituto da Conservação da Natureza, Lisboa. (http://www.icnf.pt/portal/naturaclas/patrinatur/lvv)

Carvajal-Rodríguez, A. (2008) Simulation of genomes: A review. Current Genomics, 9, $155-$ 159. 
Castoe, T.A., Streicher, J.W., Meik, J.M., Ingrasci, M.J., Poole, A.W., Koning, A.P., Campbell, J.A., Parkinson, C.L., Smith, E.N. \& Pollock, D.D. (2012) Thousands of microsatellite loci from the venomous coralsnake Micrurus fulvius and variability of select loci across populations and related species. Molecular Ecology Resources, 12, 1105-1113.

Chiarello, A., Moraes-Barros, N. \& Plese, T. (2011). Bradypus variegatus. In: IUCN 2012. IUCN Red List of Threatened Species. Version 2012.2. www.iucnredlist.org. Downloaded on 03 December 2012.

Cornuet, J.M. \& Luikart, G. (1996) Description and power analysis of two tests for detecting recent population bottlenecks from allele frequency data. Genetics, 144, 2001-2014.

Delsuc, F., Vizcaino, S.F. \& Douzery, E.J. (2004) Influence of Tertiary paleoenvironmental changes on the diversification of South American mammals: a relaxed molecular clock study within xenarthrans. BMC Evolutionary Biology, 4, 11.

Ellegren, H., Moore, S., Robinson, N., Byrne, K., Ward, W. \& Sheldon, B.C. (1997) Microsatellite evolution-a reciprocal study of repeat lengths at homologous loci in cattle and sheep. Molecular Biology and Evolution, 14, 854-860.

Estoup, A., Jarne, P. \& Cornuet, J.M. (2002) Homoplasy and mutation model at microsatellite loci and their consequences for population genetics analysis. Molecular Ecology, 11, 1591-1604.

Excoffier, L., Smouse, P.E. \& Quattro, J.M. (1992) Analysis of molecular variance inferred from metric distances among DNA haplotypes: application to human mitochondrial DNA restriction data. Genetics, 131, 479-491.

Excoffier, L., Laval, G. \& Schneider, S. (2005) Arlequin (version 3.0): an integrated software package for population genetics data analysis. Evolutionary Bioinformatics Online, 1, 47-50.

Frankham, R., Briscoe, D.A. \& Ballou, J.D. (2002) Introduction to conservation genetics. Cambridge University Press.

Fruth, B., Benishay, J.M., Bila-Isia, I., Coxe, S., Dupain, J., Furuichi, T., Hart, J., Hart, T., Hashimoto, C., Hohmann, G., Hurley, M., Ilambu, O., Mulavwa, M., Ndunda, M., Omasombo, V., Reinartz, G., Scherlis, J., Steel, L. \& Thompson, J. (2008) Pan paniscus. In: IUCN 2012. IUCN Red List of Threatened Species. Version 2012.2. www.iucnredlist.org. Downloaded on 20 April 2013.

Garcia, J.E., Vilas Boas, L.A., Lemos, M.V., Macedo Lemos, E.G. \& Contel, E.P. (2005) Identification of microsatellite DNA markers for the giant anteater Myrmecophaga tridactyla. Journal of Heredity, 96, 600-602.

Givens, G.H., Huebinger, R.M., Bickham, J.W., George, J.C. \& Suydam, R. (2007) Patterns of genetic differentiation in bowhead whales (Balaena mysticetus) from the western Arctic. 
Annual Meeting of the Scientific Committee of the International Whaling Commission. International Whaling Commission, Anchorage, USA.

Godinho, R., Llaneza, L., Blanco, J.C., Lopes, S., Álvares, F., García, E.J., Palacios, V., Cortéa, Y., Talegón, J. \& Ferrand, N. (2011) Genetic evidence for multiple events of hybridization between wolves and domestic dogs in the Iberian Peninsula. Molecular Ecology, 20, 5154-5166.

Guerier, A., Bishop, J., Crawford, S., Schmidt-Küntzel, A. \& Stratford, K. (2012) Parentage analysis in a managed free ranging population of southern white rhinoceros: genetic diversity, pedigrees and management. Conservation Genetics, 13, 811-822.

Hale, M.L., Burg, T.M. \& Steeves, T.E. (2012) Sampling for microsatellite-based population genetic studies: 25 to 30 individuals per population is enough to accurately estimate allele frequencies. PLoS ONE, 7, e45170.

Hamilton, M., Pincus, E., Di Fiore, A. \& Fleischer, R. (1999) Universal linker and ligation procedures for construction of genomic DNA libraries enriched for microsatellites. BioTechniques, 27, 500-507.

Heller, R., Lorenzen, E.D., Okello, J.B., Masembe, C. \& Siegismund, H.R. (2008) MidHolocene decline in African buffalos inferred from Bayesian coalescent-based analyses of microsatellites and mitochondrial DNA. Molecular Ecology, 17, 4845-4858.

Hoban, S., Gaggiotti, O. \& Bertorelle, G. (2013) Sample planning optimization tool for conservation and population genetics (SPOTG): a software for choosing the appropriate number of markers and samples. Methods in Ecology and Evolution.

Hutter, C.M., Schug, M.D. \& Aquadro, C.F. (1998) Microsatellite variation in Drosophila melanogaster and Drosophila simulans: a reciprocal test of the ascertainment bias hypothesis. Molecular Biology and Evolution, 15, 1620-1636.

IUCN 2012. IUCN Red List of Threatened Species. Version 2012.2. www.iucnredlist.org. Downloaded on 20 April 2013.

Jombart, T. (2008) Adegenet: a R package for the multivariate analysis of genetic markers. Bioinformatics, 24, 1403-1405.

Kalinowski, S.T. (2002) How many alleles per locus should be used to estimate genetic distances? Heredity, 88, 62-65.

Kaviar, S., Shockey, J. \& Sundberg, P. (2012) Observations on the endemic pygmy threetoed sloth, Bradypus pygmaeus of Isla Escudo de Veraguas, Panama. PLoS ONE, 7, e49854.

Kleven, O., Hallström, B.M., Hailer, F., Janke, A., Hagen, S.B., Kopatz, A. \& Eiken, H.G. (2012) Identification and evaluation of novel di- and tetranucleotide microsatellite markers from the brown bear (Ursus arctos). Conservation Genetics Resources, 4, 737-741. 
Koskinen, M.T., Hirvonen, H., Landry, P.-A. \& Primmer, C.R. (2004) The benefits of increasing the number of microsatellites utilized in genetic population studies: an empirical perspective. Hereditas, 141, 61-67.

Lacy, R.C. (1987) Loss of genetic diversity from managed populations: interacting effects of drift, mutation, immigration, selection, and population subdivision. Conservation Biology, 1, 143-158.

Lara-Ruiz, P., Chiarello, A.G. \& Santos, F.R. (2008) Extreme population divergence and conservation implications for the rare endangered Atlantic Forest sloth, Bradypus torquatus (Pilosa: Bradypodidae). Biological Conservation, 141, 1332-1342.

Ljungqvist, M., Åkesson, M. \& Hansson, B. (2010) Do microsatellites reflect genome-wide genetic diversity in natural populations? A comment on Väli et al. (2008). Molecular Ecology, $19,851-855$.

Luikart, G., Allendorf, F.W., Cornuet, J.M. \& Sherwin, W.B. (1998) Distortion of allele frequency distributions provides a test for recent population bottlenecks. Journal of Heredity, 89, 238-247.

Luo, W., Nie, Z., Zhan, F., Wei, J., Wang, W. \& Gao, Z. (2012) Rapid development of microsatellite markers for the endangered fish Schizothorax biddulphi (Günther) using next generation sequencing and cross-species amplification. International Journal of Molecular Sciences, 13, 14946-14955.

Markert, J.A., Champlin, D.M., Gutjahr-Gobell, R., Grear, J.S., Kuhn, A., McGreevy, T.J., Roth, A., Bagley, M.J. \& Nacci, D.E. (2010) Population genetic diversity and fitness in multiple environments. BMC Evolutionary Biology, 10, 205.

Mech, L.D. \& Boitani, L. (2010) Canis lupus. In: IUCN 2012. IUCN Red List of Threatened Species. Version 2012.2. www.iucnredlist.org. Downloaded on 20 April 2013.

Mejía, O., Herrera M, L.G., May, B., Medellín, R.A. \& Flores-Martínez, J.J. (2011) Effective population size dynamics of Myotis vivesi during the Pleistocene and Holocene climatic changes. Acta Chiropterologica, 13, 33-40.

Miotto, R.A., Cervini, M., Begotti, R.A. \& Galetti Jr, P.M. (2012) Monitoring a Puma (Puma concolor) population in a fragmented landscape in Southeast Brazil. Biotropica, 44, 98-104.

Moraes-Barros, N., Miyaki, C.Y. \& Morgante, J.S. (2007) Identifying management units in non-endangered species: the example of the sloth Bradypus variegatus Schinz, 1825. Brazilian Journal of Biology, 67, 829-837.

Moraes-Barros, N., Morgante, J.S. \& Miyaki, C.Y. (2002) Genetic diversity in different populations of sloths assessed by DNA fingerprinting. Brazilian Journal of Biology, 62, 503508. 
Moraes-Barros, N., Silva, J.A., Miyaki, C.Y. \& Morgante, J.S. (2006) Comparative phylogeography of the Atlantic forest endemic sloth (Bradypus torquatus) and the widespread three-toed sloth (Bradypus variegatus) (Bradypodidae, Xenarthra). Genetica, 126, 189-198.

Moraes-Barros, N., Silva, J.A.B. \& Morgante, J.S. (2011) Morphology, molecular phylogeny, and taxonomic inconsistencies in the study of Bradypus sloths (Pilosa: Bradypodidae). Journal of Mammalogy, 92, 86-100.

Moraes-Barros, N.d., Giorgi, A.P., Silva, S.M. \& Morgante, J.S. (2010) Reevaluation of the geographical distribution of Bradypus tridactylus Linnaeus, 1758 and B. variegatus Schinz, 1825. Edentata, 11, 53-61.

Nikolic, N., Fève, K., Chevalet, C., Høyheim, B. \& Riquet, J. (2009) A set of 37 microsatellite DNA markers for genetic diversity and structure analysis of Atlantic salmon Salmo salar populations. Journal of Fish Biology, 74, 458-466.

Oates, J.F., Tutin, C.E.G., Humle, T., Wilson, M.L., Baillie, J.E.M., Balmforth, Z., Blom, A., Boesch, C., Cox, D., Davenport, T., Dunn, A., Dupain, J., Duvall, C., Ellis, C.M., Farmer, K.H., Gatti, S., Greengrass, E., Hart, J., Herbinger, I., Hicks, C., Hunt, K.D., Kamenya, S., Maisels, F., Mitani, J.C., Moore, J., Morgan, B.J., Morgan, D.B., Nakamura, M., Nixon, S., Plumptre, A.J., Reynolds, V., Stokes, E.J. \& Walsh, P.D. (2008) Pan troglodytes. In: IUCN 2012. IUCN Red List of Threatened Species. Version 2012.2. www.iucnredlist.org. Downloaded on 20 April 2013.

Ostrander, E.A., Jong, P.M., Rine, J. \& Duyk, G. (1992) Construction of small-insert genomic DNA libraries highly enriched for microsatellite repeat sequences. Proceedings of the National Academy of Sciences, 89, 3419-3423.

Piry, S., Luikart, G. \& Cornuet, J.M. (1999) BOTTLENECK: A computer program for detecting recent reductions in the effective population size using allele frequency data. Journal of Heredity, 90, 502-503.

Quéméré, E., Amelot, X., Pierson, J., Crouau-Roy, B. \& Chikhi, L. (2012) Genetic data suggest a natural prehuman origin of open habitats in northern Madagascar and question the deforestation narrative in this region. Proceedings of the National Academy of Sciences, 109, 13028-13033.

Quéméré, E., Crouau-Roy, B., Rabarivola, C., Louis Jr, E.E. \& Chikhi, L. (2010) Landscape genetics of an endangered lemur (Propithecus tattersalli) within its entire fragmented range. Molecular Ecology, 19, 1606-1621.

R Development Core Team (2008) R: A language and environment for statistical computing. $\mathrm{R}$ Foundation for Statistical Computing, Vienna, Austria. ISBN 3-900051-07-0, URL http://www.R-project.org. 
Razafindrakoto, A., Quéméré, E., Shore, G.D., McGuire, S.M., Louis Jr, E.E. \& Brenneman, R.A. (2008) Characterization of 20 microsatellites marker loci in the golden-crowned sifaka (Propithecus tattersalli). Conservation Genetics, 9, 1027-1031.

Reed, D.H. \& Frankham, R. (2003) Correlation between fitness and genetic diversity. Conservation Biology, 17, 230-237.

Reinartz, G.E., Karron, J.D., Phillips, R.B. \& Weber, J.L. (2000) Patterns of microsatellite polymorphism in the range-restricted bonobo (Pan paniscus): considerations for interspecific comparison with chimpanzees (P. troglodytes). Molecular Ecology, 9, 315-328.

Røed, K.H., Ernest, E.M., Midthjell, L., Msoffe, P.L.M. 2011 Identification and characterization of 17 microsatellite loci in the blue wildebeest, Connochaetes taurinus. Conservation Genetics Resources 3, 181-183.

Seddon, J.M., Parker, H.G., Ostrander, E.A. \& Ellegren, H. (2005) SNPs in ecological and conservation studies: a test in the Scandinavian wolf population. Molecular Ecology, 14, 503510 .

Superina, M., Plese, T., Moraes-Barros, N. \& Abba, A.M. (2010) The 2010 Sloth Red List Assessment. Edentata, 11, 115-134.

Väli, U., Einarsson, A., Waits, L. \& Ellegren, H. (2008) To what extent do microsatellite markers reflect genome-wide genetic diversity in natural populations? Molecular Ecology, 17, 3808-3817.

van Oosterhout, C., Hutchinson, W.F., Wills, D.P.M. \& Shipley, P. (2004) Micro-checker: software for identifying and correcting genotyping errors in microsatellite data. Molecular Ecology Notes, 4, 535-538.

Vowles, E.J. \& Amos, W. (2006) Quantifying ascertainment bias and species-specific length differences in human and chimpanzee microsatellites using genome sequences. Molecular Biology and Evolution, 23, 598-607.

Warnes, G.R., Bolker, B. \& Lumley, T. (2010) gtools: Various R programming tools. URL http://CRAN. R-project. org/package= gtools. $\mathrm{R}$ package version, 2. 


\title{
CAPítulo 6. Towards a standard framework to describe behaviours in the common sloth (Bradypus variegatus): novel interactions data observed in distinct fragments of the Atlantic forest, Brazil.
}

Sofia M. Silva, Camila L. Clozato, Nadia Moraes-Barros \& João S. Morgante (2013) Brazilian Journal of Biology. 73.3: *****.

\begin{abstract}
The common three-toed sloth is a widespread species, but the location and the observation of its individuals are greatly hindered by its biological features. Their camouflaged pelage, its slow and quiet movements, and the strictly arboreal habits resulted in the publication of sparse, fragmented and not patterned information on the common sloth behaviour. Thus, herein we propose an updated standardized behavioural categories' framework to the study of the species. Furthermore we describe two never reported interaction behaviours: a probable mating / courtship ritual between male and female; and apparent recognition behaviour between two males. Finally we highlight the contribution of small-duration field works in this elusive species ethological study.
\end{abstract}

\section{Keywords}

Common three-toed sloth - Recognition behaviour - Male-female interactions

\section{Introduction}

The common three-toed sloth, Bradypus variegatus (Schinz 1825), is an obligatory arboreal mammal. Life in the trees' canopy, their slow and silent movements, together with a camouflaged pelage makes sloths extremely difficult to be observed in nature. Consequently, although the common sloth's widespread distribution (Moraes-Barros et al. 2010), few ecological studies were made so far (Ballesteros et al. 2009; Consentino 2004; Queiroz 1995; Soares \& Carneiro 2002; Urbani \& Bosque 2006; Vaughan et al. 2007), and basic ethological data are barely understood. For instance, reproductive means were only reported once (Bezerra et al. 2008), more descriptive parental care three times (Bezerra et al. 2008; Pinheiro 2008; Soares \& Carneiro 2002), and territorial occupancy is unclear (Bezerra et al. 2008; Hayssen 2010; Lara-Ruiz \& Srbeck-Araujo 2006). Even this mammal's social system is controversial. Although it is mostly described as being solitary (reviewed by Hayssen 2010), and interactions between adult common sloth individuals have been only occasionally reported (Ballesteros et al. 2009; Bezerra et al. 2008; Consentino 2004; Greene 1989; Lara-Ruiz \& Srbeck-Araujo 2006; Vaughan et al. 2007), these animals can be quite gregarious (Ballesteros et al. 2009; Vaughan et al. 2007). Also they were reported to occur in several small confined areas, such as public 
gardens and municipal squares (Consentino 2004; Manchester \& Jorge 2009; Pinheiro 2008), and even share trees with other sloth's species (Sunquist \& Montgomery 1973; Vaughan et al. 2007).

According to Greene (1989), only long-term animal observation studies could witness less usual common sloth behaviours. Nevertheless such studies were not able to fully describe this species' ecology, so far (e. g. Consentino 2004; Queiroz 1995). However, the same author also claimed that small carefully designed studies could be important contributions to the common sloth study (Greene 1989).

In this context, we intended to address the contribution of opportunistic and small duration field studies on the behaviour of the common sloth. As a result, i) we suggest an updated standardised behavioural categories' framework to describe common sloth behaviour. And ii) report novel behaviour data for the species, in two Brazilian Atlantic forest localities. We describe male-male and male-female interactions, disentangling new insights on common sloths ethology.

\section{Materials and Methods}

\section{Study areas}

We visited two preserved areas within the Brazilian Atlantic forest: i) at the Serra dos Órgãos National Park (PARNASO, $22^{\circ} 29^{\prime} \mathrm{S} / 43^{\circ} 00^{\prime} \mathrm{W}$; Fig. 1), located in the state of Rio de Janeiro, south-eastern Brazil, between 14 and 19 August 2010; and ii) the Botanic Garden Benjamin Maranhão (BGBM, 0708'44"S/3451'42"W; Fig. 1), located at the state of Paraiba, north-eastern Brazil, between 19 to 22 July 2011. The topography of the first area visited is complex and the altitude ranges from 350 to $1.100 \mathrm{~m}$. As for the second area, it ranges between 0 to $250 \mathrm{~m}$. The approximate temperature during the sampling days in PARNASO ranged from $7^{\circ} \mathrm{C}$ and $21^{\circ} \mathrm{C}$, and average insolation hours per day was $4.4 \mathrm{~h}$, while the thermic amplitude for the sampling days in $\mathrm{BGBM}$ was $21^{\circ} \mathrm{C}-29^{\circ} \mathrm{C}$ and $6.3 \mathrm{~h}$ of average insolation per day (INMET 2011). PARNASO's area is surrounded by forest and visits are restricted, while BGBM is a forested fragment located within an urban area.

\section{Methodology}

The initial purpose of the expeditions to the selected forest fragments was collecting biological material for population genetic studies. Given that our main goal was observing the maximum individuals as possible, and when possible capture them for sampling, we inspected all roads, tracks and open sections within both areas at least once a day. However, during all the period we observed and recorded sloth's behaviour, no individual was captured. 


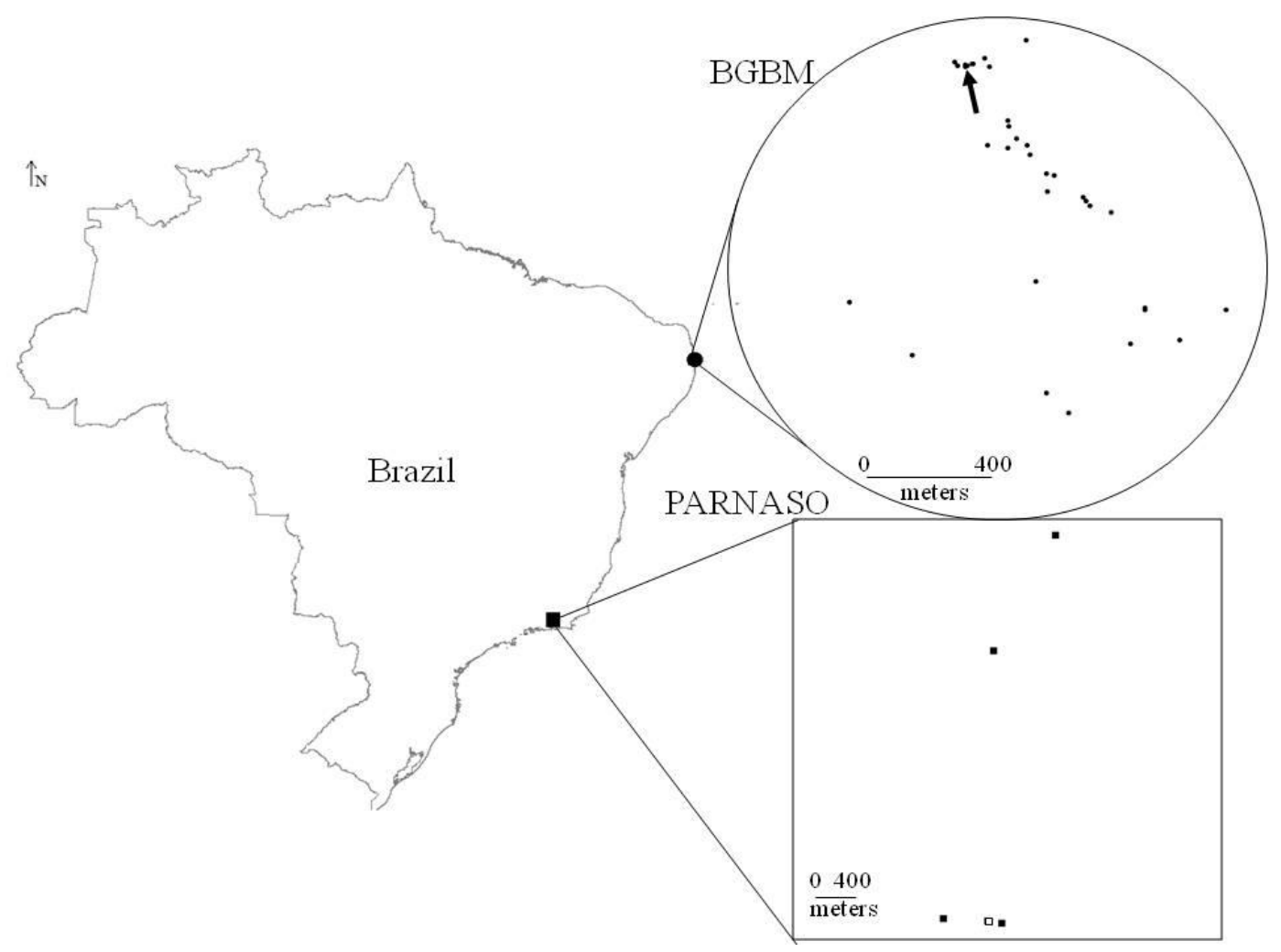

Figure 1. Total geographical records of common-sloths, Bradypus variegatus, obtained during field work in the two distinct Atlantic forest regions. Circles represent records in BGBM (Bothanical Garden Benjamin Maranhão) and squares in PARNASO (Serra dos Órgãos National Park). In PARNASO the location of the male-female interaction is depicted as an open square. As for BGBM, all the interactions' location is indicated by an arrow.

Common sloth adult males were recognized by the presence of a dorsal speculum, and adult females by its absence (Hayssen 2010). An animal was considered to be the same individual in different days of field work if it was found in the same tree or at least in the adjacent ones and no ambiguity was detected (Urbani \& Bosque 2006).

Also, every time a common sloth was found we did a simple record of their posture and behaviour, according to Urbani \& Bosque (2006). Few studies had made an exhaustive description of common sloth behaviours (Consentino 2004; Queiroz, 1995; Urbani \& Bosque 2006). Thus we have chosen to follow Urbani \& Bosque (2006) description because the authors based their categories both in their own field experience and in previous works. We kept observing the same individual until no changes occurred both in posture and in behaviour. Whenever possible, pictures and videos were taken and GPS point recorded. DIVA-GIS 7.1.7 (Hijmans et al. 2005) was used to plot the geographical records.

Field work was performed under Instituto Brasileiro do Meio Ambiente (IBAMA) permission (no. 19267-3/14597869). 


\section{Results}

\section{Updated standardised behavioural categories' framework}

We have completed $36.3 \mathrm{~h}$ of field work at PARNASO and 19.6h at BGBM. In PARNASO we saw an average of three individuals/day, and in BGBM 17.25 individuals/day. The observations of all individuals resulted in 93 behaviour records, discriminated in Fig. 2 and Appendix I.

Although the limited time of observation, we have recorded two events of interaction among common sloth adults.

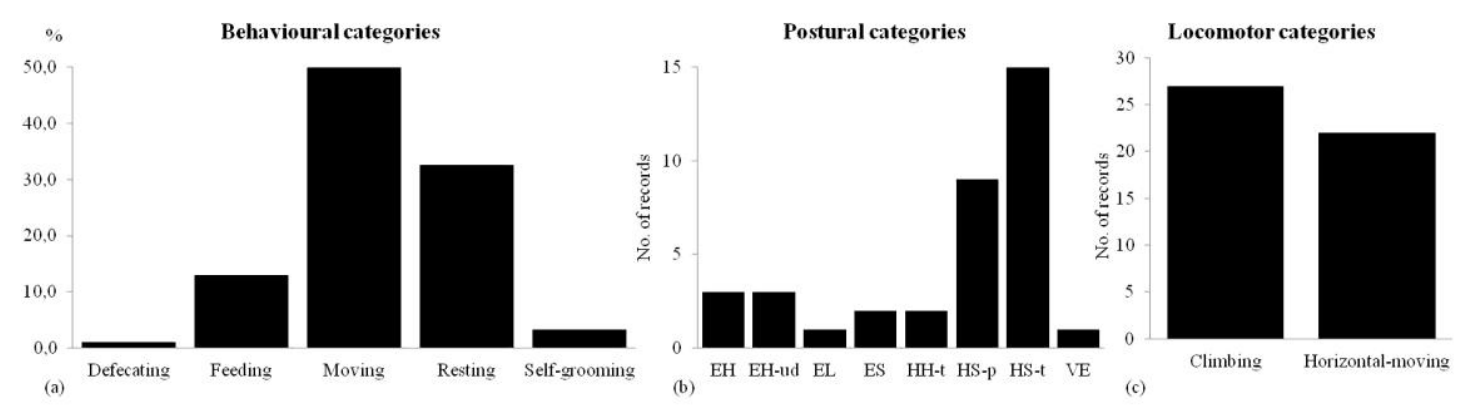

Figure 2. Frequency of observed behaviour (a), posture (b), and locomotor (c) categories of the common sloth Bradypus variegatus in two areas of the Brazilian Atlantic forest (Serra dos Órgãos National Park and Botanic Garden Benjamin Maranhão). "EH" represents the extended hanging, category; "EH-ud" represents the extended hanging upside down category; "L" represents the extended lying category; "ES" represents the extended sitting category; "HH-t" represents the huddle hanging-total category; "HS-p" represents the huddle sitting-partial category; "HS-t" represents the huddle sitting-total category; "VE" represents the vertically extended category.

\section{Novel behaviour data}

In PARNASO, at 14 August 2010, around 3:00 p.m., a female common sloth (sloth $I$ ) was observed for the first time. It was a rainy day, and the individual was huddle sitting-total (Hs-t). Days became progressively less cloudy across field-work, but foggy particularly at dawn and dusk. Sloth $I$ was seen alone in the next two days. But at 18 August, around 9:00 a.m., a male (sloth $I I$ ) was feeding and sharing the tree with the sloth $I$, although in different branches. At 19 August, around 3:00 p.m., II climbed the tree towards I, which was feeding. At some point, II stopped, stretched its head towards the sloth $I$ and then climbed closer to it. Then, II outstretched its foreleg and $I$ followed it, outstretching both its forelegs, one at a time. Then II struck vigorously the tree trunk twice, and climbed the tree (Fig. 3a). The sloth $I$ returned feeding. The whole encounter lasted for less than two minutes. One hour and a half later, $I I$ was seen about $40 \mathrm{~m}$ away from that tree, where $I$ kept resting, and it moved at least $10 \mathrm{~m}$ more, when it was out of sight.

In BGBM, at 19 July 2011, we first spotted a female common sloth at an Hs-t posture, around 8:30 a.m. (sloth $I I I$ ). Ten minutes later, a male climbed that same tree (sloth $I V$ ), and 
kept Hs-t very close to III (Fig. 3b). That day, we were only able to work during the morning because it rained heavily all afternoon. All other days were sunny. At 20 July, we arrived at the same spot around the same hour. There we observed four individuals in two adjacent trees. Two sloths were in opposite sides of the canopies at about $20 \mathrm{~m}$ from each other. And in the middle, we saw the other two animals in contact (Fig. 3c, d). These were both males and we named them as sloths $V$ and $V I$, although one of them could be the male seen the day before (sloth $I V$ ), but we were not able to distinguish it, given we have just considered the geographical position as aforementioned. $V I$ seemed to smell $V$, and grabbed it, when $V$ tried to move. $V$ looked to and probably also smelled VI. For five minutes more $V I$ reached and smelled $V$, while $V$ kept moving (Fig. 3c, d). Then they separated and $V$ huddle sitting-partial (Hs-p), while VI selfgroomed in an extended hanging $(\mathrm{EH})$ posture.

a)

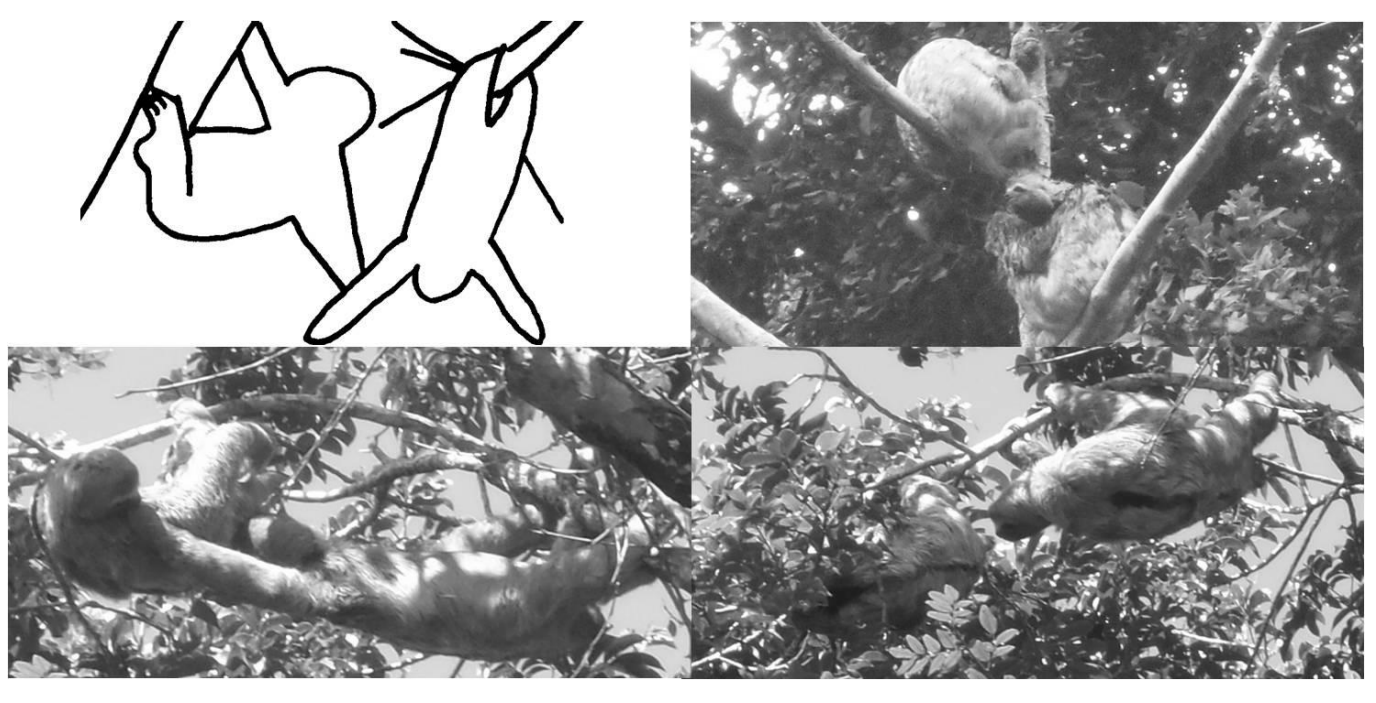

c)

d)

Figure 3. Interactions between the common sloth Bradypus variegatus individuals. a) Representation of the last event of interaction recorded in PARNASO, between female $I$ (at right) and male $I I$ (at left). b) In BGBM, female $I I I$ (at left) and male $I V$ (at right) sharing the same tree. c) Male $V$ (at right) often grabbed, smelled and impeded the movements of the male VI (at left). d) V chased VI before they separate.

\section{Discussion}

\section{Updated standardised behavioural categories' framework}

Currently, the few common sloth behaviour studies published do not use the same terminology to address the same posture and locomotion events on common sloth (e.g. Ballesteros et al. 2009; Consentino 2004; Mendel 1985; Queiroz 1995; Urbani \& Bosque 2006; Vaughan et al. 2007). So, as stated in the Methodology section, we have chosen a list of behaviour categories that had considered previous behaviour description on common sloth (Urbani \& Bosque 2006). Yet, in our opinion, Urbani \& Bosque‘s (2006) categorization was not able to fully describe the common sloth behaviours. For all this, we propose two more postural 
categories, given their distinctiveness: the extended lying posture (EL, description: stationary; supported by all limbs, ventral surfaces against the tree trunk), and the vertically extended posture (VE, description: stationary; supported by all limbs, ventral surfaces against the tree trunk in a vertical position). Also, we have discriminated the extended hanging upside down (EH-ud) posture, because we observed common sloths not only resting and grooming in that posture, but also feeding. Furthermore, we have considered defecating as a behavioural category, and we suggest that future studies should consider sun-bathing as a sub-resting category, once it was a recurrent behaviour in common sloths.

\section{Novel behaviour data}

Previously reported interactions between common sloth individuals only concerned antagonistic behaviour between males (Ballesteros et al. 2009; Consentino, 2004; Greene 1989); reproductive means (Bezerra et al. 2008) and tree sharing between individuals of different genders (Ballesteros et al. 2009; Vaughan et al. 2007) or females (Consentino 2004). The common sloth $I I$ initially stretched its head towards the sloth $I$ suggesting that scent was used to recognize the other individual. Scent has already been proposed to be used by a male when searching a receptive female (Lara-Ruiz \& Srbeck-Araujo 2006). Furthermore, the interaction observed in PARNASO did not involve physical contact as in an antagonistic encounter (Consentino 2004; Greene 1989). Therefore, we infer that we witnessed a strength display in a mating or courtship ritual by the male $I I$ towards the female $I$, although no vocalization was heard in the days or hours before the events described (Bezerra et al. 2008; Lara-Ruiz \& Srbeck-Araujo 2006).

Scent also seems to be involved in the interaction between the two BGBM males ( $V$ and $V I)$. The same arguments and data described in the preceding paragraph lead us to conclude that this second interaction was a recognition behaviour, rather than an antagonistic one. Furthermore the adjacent tree where $V$ and $V I$ interacted was shared by $I I I$ and $I V$, and in its surroundings, we found an average of 26 individuals/ha/day, so a pacific coexistence is likely to happen.

This density is far higher than the ones previously estimated in large forested areas (from $2.12 \mathrm{ind} /$ ha [Queiroz 1995] to $8.5 \mathrm{ind} /$ ha [Montgomery \& Sunquist 1975]), and probably higher than in PARNASO. The higher density in BGBM, probably is due to the fact that this area is a forested patch surrounded by urbanizations. Although these records indicate a gregarious social system, probably it is not optional, but mandatory due to the confinement of animals to small forested patches. Gregarious behaviours, both in Costa Rica and Colombia, were recorded in humanized habitats (Ballesteros et al. 2009; Vaughan et al. 2007), and densities up to 17ind/ha can be inferred from previous observations in public gardens and municipal squares (Manchester \& Jorge 2009; Moraes-Barros pers. obs.). 


\section{Conclusion}

Our updated framework (Urbani \& Bosque 2006; plus our proposed categories) will be a useful tool in the standardise description of common sloth behaviour in natural environments. It enables the comparison between different studies, both qualitatively (it assures that exactly the same posture and locomotion events are being named when different people are observing the common sloth individuals), as quantitatively (allows the correct behavioural categories' frequency comparison).

Furthermore, we add evidences that scent is one of the most important senses for the common sloth day-to-day, and we further support the species ability to live gregariously, opposed to its commonly accepted solitary habits.

Finally, irrespectively of weather conditions, altitude and population density, we were able to describe more postural and locomotion categories than long-duration field studies and report novel interaction data on this species. These facts emphasize and confirm Greene's (1989) statement that small carefully designed studies can effectively contribute to the common sloth behaviour study.

\section{Acknowledgements}

Authors would like to thank Cecilia Cronemberg, Frederico Pimentel, Paula Vianna, and Thiago Bessa Telles for their help in PARNASO. In BGBM we appreciate the help of José Anderson Feijó, Suênia Oliveira and the Environmental Police of the BGBM unit. Finally we thank Gustavo Requena for providing valuable feedback on previous versions of this manuscript. S.M. Silva is supported by a Foundation for Science and Technology $\mathrm{PhD}$ grant (SFRH/BD/40638/2007). C.L. Clozato and N. Moraes-Barros are supported by CAPES. J.S. Morgante is granted with a research award from FAPESP (08/52207-0).

\section{References}

Ballesteros J., Reyes K., Racero J. 2009. Estrutura poblacional y etología de Bradypus variegatus en fragmento de bosque seco tropical, Córdoba - Colombia. Journal MVZ Córdoba 14:1812-1819.

Bezerra BM., Souto AS., Halsey LG., Schiel N. 2008. Observation of brown-throated threetoed sloths: mating behaviour and the simultaneous nurturing of two young. Journal of Ethology 26:175-178.

Consentino L. 2004. Aspectos do comportamento da preguiça comum, Bradypus variegatus (Xenarthra, BRADYPODIDAE) em uma área de semi-cativeiro no município de Valença - Rio de Janeiro. Ms.C. Thesis. Universidade Rural do Rio de Janeiro. 
Greene HW. 1989. Agonistic behavior by three-toed sloths, Bradypus variegatus. Biotropica, 21:369-372.

Hayssen V. 2010. Bradypus variegatus (Pilosa: Bradypodidae). Mammalian Species 42:1932.

Hijmans RJ., Guarino L., Bussink C., Barrantes I., Rojas E. 2005. DIVA-GIS, Version 7.1.7.2. http://www.diva-gis.org (last accessed 07 September 2011).

INMET 2011. Instituto Nacional de Meteorologia. http://www.inmet.gov.br/ (last accessed 04 September 2011).

IUCN 2010. IUCN Red list of threatened species. Version 2010.1 www.iucnredlist.org (last accessed 15 March 2010).

Lara-Ruiz P., Srbek-Araujo AC. 2006. Comportamento potencialmente reprodutivo da preguiça-comum, Bradypus variegatus (Xenarthra, Bradypodidae): observações de campo. Edentata 7:44-46.

Manchester A., Jorge W. 2009. Biological data of a population of sloths (Bradypus variegatus) in a square of Teófilo Otoni, Minas Gerais, Brazil. Naturalia 32: 81-86.

Mendel FC. 1985. Use of hands and feet of three-toed sloths (Bradypus variegatus) during climbing and terrestrial locomotion. Journal of Mammalogy 66:359-366.

Montgomery GC., Sunquist ME. 1975. Impact of sloths on Neotropical forest energy flow and nutrient cycling. In: Tropical Ecological Systems: Trends in Terrestrial and Aquatic Research. Edited by Golley F.B. \& Medina E. 69-98. New York: Springer Verlag.

Moraes-Barros N, Giorgi AP., Silva SM., Morgante JS. 2010. Reevaluation of the geographical distribution of Bradypus tridactylus Linnaeus, 1758 and B. variegatus Schinz, 1825. Edentata 11:53-61.

Pinheiro SD. 2008. Comportamento alimentar da preguiça comum Bradypus variegatus (Schinz, 1825) (Xenarthra, Bradipodidade) no Parque Centenário de Barra Mansa - RJ, Universidade Federal de Juiz de Fora, Juiz de Fora. 122 pp.

Queiroz HL. 1995. Preguiças e guaribas. Os mamíferos folívoros arborícolas do Mamirauá. Brasília: CNPq-Sociedade Civil Mamirauá.

Soares CA., Carneiro R.S. 2002. Social behavior between mothers x young of sloths Bradypus variegatus Schinz, 1825 (Xenarthra: Bradypodidae). Brazilian Journal of Biology 62:249-252.

Sunquist ME., Montgomery GC. 1973. Activity patterns and rates of movement of two-toed and three-toed sloths (Choloepus hoffmanni and Bradypus infuscatus). Journal of Mammalogy 54:946-54.

Urbani B., Bosque C. 2006. Feeding ecology and postural behaviour of the three-toed sloth (Bradypus variegatus flaccidus) in northern Venezuela. Mammalian Biology 72:321-329. 
Vaughan C., Ramírez O., Herrera G., Guries R. 2007. Spatial ecology and conservation of two sloth species in a cacao landscape in Limón, Costa Rica. Biodiversity and Conservation 16:2293-2310. 


\title{
CAPítulo 7. Contribution of governmental centers for wildlife to study the biology of sloths (Bradypus variegatus) in Brazilian anthropogenic habitats.
}

Sofia M. Silva, Juliana L. Summa, Maria Eugênia L. Summa, Vilma Clarice Geraldi, Marius

Belluci, Alberto Klefasz, João Stenghel Morgante, Nadia de Moraes-Barros (em preparação)

\begin{abstract}
Our study evaluated anthropogenic threats to the common sloth in the Brazilian Atlantic forest, by analyzing data collected in governmental facilities for wildlife. Main menaces were the extensive road network, falls, domestic dogs and lethal electric shocks. We confirm the rainy season as the species' birth season within the southeast, but not in the northeast, where a year-round breeding season seems likely. The absence of sexual dimorphism was confirmed, by the highest number of adults' weight records ever analyzed. Although these facilities cope with the lack of human resources, their data adds important biological information to the study of wildlife.
\end{abstract}

\section{Keywords}

Anthropogenic threats - Bradypus variegates - Brazilian Atlantic forest - Common sloth

\section{Introduction}

Bradypus variegatus, the common sloth, is a slow moving sloth species, behavior associated with their low metabolism resulting from a poor diet (Nagy \& Montgomery 1980), which consequently causes a low body temperature (Britton \& Atkinson 1938; Mühlbauer et al. 2006). These animals are highly adapted to forested habitats, being folivores, and rarely leaving the canopy (Sunquist \& Montgomery 1973). This behavior makes sloths extremely forestdependent, and consequently deforestation is the major threat this species is facing (Chiarello et al. 2011).

Despite the low vagility (Sunquist \& Montgomery 1973), natural predation is not a considerable menace, namely because the species has a camouflage afforded by symbiotic algae on its fur (Britton 1941). Thus only a small number of large carnivores and birds of prey hunt sloths, mostly opportunistically (Garla et al. 2001; Wang 2002; Vaughan et al. 2007; Voirin et al. 2009). However, the threat increases when human communities are considered. Subsistence, medical, artisanal, and illegal traffic activities, as well as hunting by domestic dogs, seem to menace the common sloth (Peres 2000; Moreno \& Please 2006; Vaughan et al. 2007; Ballesteros et al. 2009; Noss et al. 2008).

In Brazil, few studies have quantified these threats. As far as we could evaluate, only Xavier et al. (2010) pointed out electric shocks in high voltage cables as one of the principal menaces 
to the survival of these animals in Brazilian territory. Evaluating additional menaces is mandatory to estimate the real degree of threat of these common sloth populations. This is particularly compelling within the Brazilian Atlantic forest (BAF), where genetically distinct and geographically isolated common sloth management units (MUs) are found (Phillips et al. 2006; Moraes-Barros et al. 2007; Silva et al. previous chapters), the most populated Brazilian cities are located, and about $92 \%$ of the territory has been lost and continues to be deforested (Myers et al. 2000; Fundação SOS Mata Atlântica \& INPE 2011).

One of the Brazilian Institute of Environment and Renewable Natural Resources (IBAMA) measures to preserve the Brazilian wildlife resources is the creation of Screening Centers for Wild Animals (CETAS). These facilities receive, identify, mark, triage, evaluate, recover, and rehabilitate wild animals, either rescued from illegal captures, nature or captivity (normative instruction no. 169/2008). Currently, there are at least 50 CETAS, covering a considerable part of the Brazilian territory (Porto 2009). The Technical Division of Veterinary Medicine and Management of the Wild Fauna (Fauna Division) of the São Paulo Municipality (DEPAVE-SP), also performs a similar work in the management of wild animals, often in collaboration with other governmental or particular institutions (Porto 2009; Moraes-Barros et al. 2006).

In this study, our main goal was to use data collected in CETAS along the BAF, and DEPAVE-SP, to increase the information on threats to the common sloth, as well as estimate important data regarding the species biology. Although the data we obtained fell short of our expectations, we conclude that collaboration among wild animals' management facilities, universities, and research centers can contribute to the faunal protection and improve scientific knowledge on the species biology.

\section{Methods}

Governmental agencies across BAF region were visited and contacted, namely several CETAS and DEPAVE-SP. For each contacted agency and whenever available, we computed common sloth records and classified them according to reason of capture, date of arrival, sex, age class, weight, among others categories. We also used data from Pernambuco's CETAS (CETAS-PE) previously published by Xavier et al. (2010). Descriptive statistics and hypothesis tests were performed in Microsoft Office Excel 2007 and R 2.15.1 (R Development Core Team 2008). Whenever enough data was available, statistical significance was tested by one-sided permutation tests, performed over 1000 permutations in R 2.15.1 (R Development Core Team 2008).

\section{Results and Discussion}

A total of 161 common sloth records from November 1992 to December 2012 were registered in DEPAVE-SP. From 1994 to 2012, additional 22 routine and sanitary records were 
also registered by this agency concerning animals from Parque da Luz, a municipal garden in the centre of São Paulo city. About $16.4 \%$ of the DEPAVE-SP records refer to animals caught more than one time, however this was irrelevant for our analyses. In Alagoas' CETAS (CETASAL), 116 records were registered during 2010; and seven common sloth records in Ceará's CETAS (CETAS-CE) from 2007 to 2011, totalizing 306 common sloth records. We added data from CETAS-PE published by Xavier et al. (2010), divided in the two datasets available: a year-counts dataset of 531 common sloth records (from 2001 to 2009), and a total of 151 monthly-registered occurrences, during 2008 and 2009 (Xavier et al. 2010 and Barros 2004 in Xavier et al. 2010; Graphs 1 and 2).

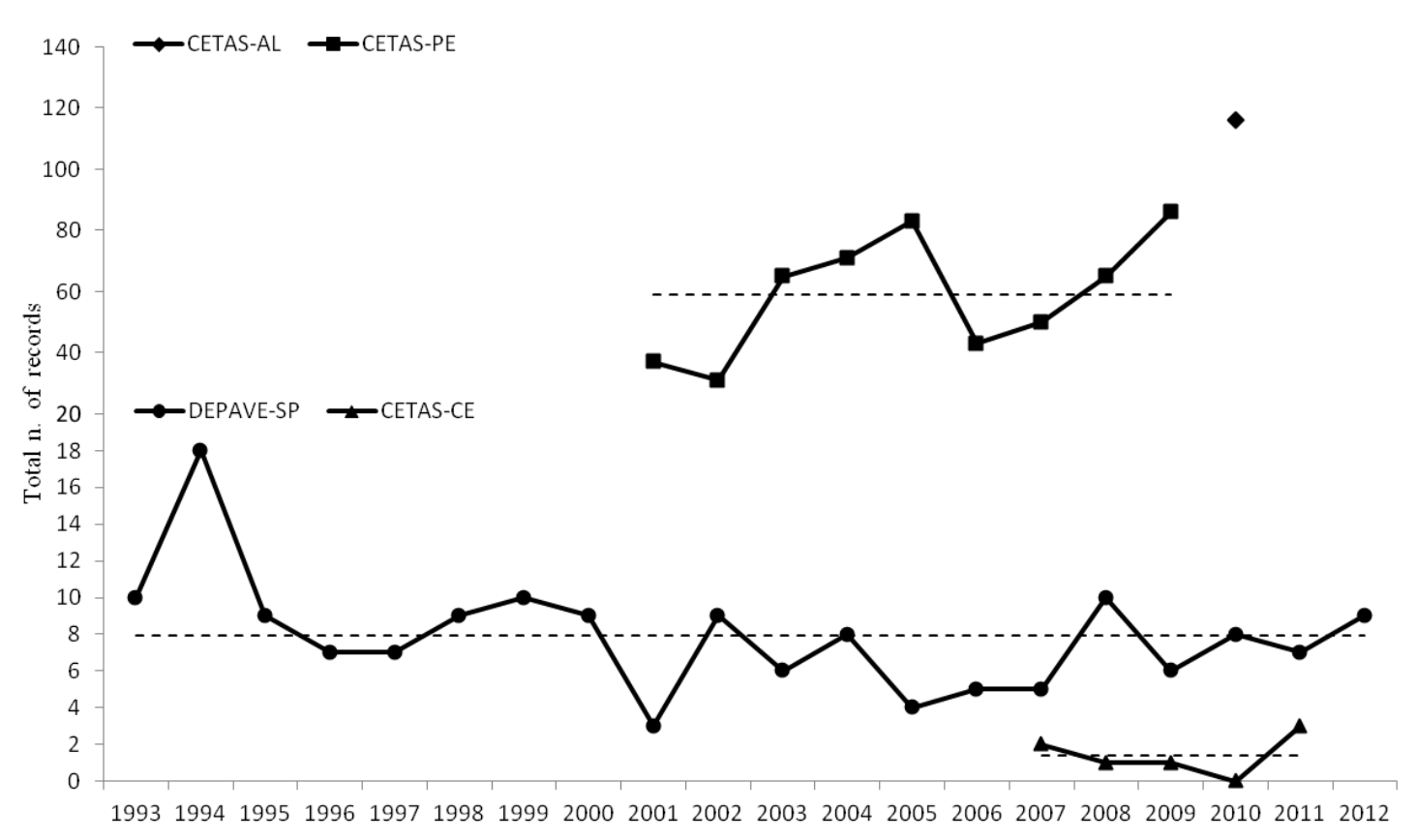

Graph 1. Records registered for the common sloth (Bradypus variegatus) by year and wild animals' facility (thick lines), and respective average (thin lines). CETAS-AL - Screening Centre for Wild Animals from Alagoas (diamonds), CETAS-PE - Screening Centre for Wild Animals from Pernambuco (squares; Xavier et al. 2010 and Barros 2004 in Xavier et al. 2010), DEPAVE-SP - Faunal Division from São Paulo (circles), and CETAS-CE - Screening Centre for Wild Animals from Ceará (triangles). Note that vertical scale is divided in two. DEPAVE-SP data from 1992 was excluded, because referred only to November and December.

It is neither methodical nor continuous practice to collect extensive data related to each animal arriving in all the CETAS (e.g., data about the individual's sex, weight, or age class). Rocha-Mendes et al. (2006) have proposed a comprehensive form to be filed for each mammal specimen. However, the lack of human resources, the large number of animals arriving, the majority needing immediate health care, and the urgency in releasing back in nature, hinders the complete data collection (J.L.S., M.E.L.S., M.B., A.K. pers. comm.). Due to the different "quality" of the data, we have represented different graphics for each facility, expressing the 
number of individuals arriving by month each year (from 2007 to 2011 to comparison; Graph 2), and by age class for CETAS-AL and DEPAVE-SP's data, also along the same year (2010) to comparison (Graph 3). Records from these two agencies represent distinct regions, which encompass the most genetically divergent common sloth populations described within BAF (Moraes-Barros et al. 2007; Silva et al. previous chapters). DEPAVE-SP has been recording common sloth arrivals for a longer period of time, so the total available dataset is represented in a separate figure (Graph 4). Although the inconsistent quality of the records; some interesting patterns could be retrieved from the data analysis, as described below.

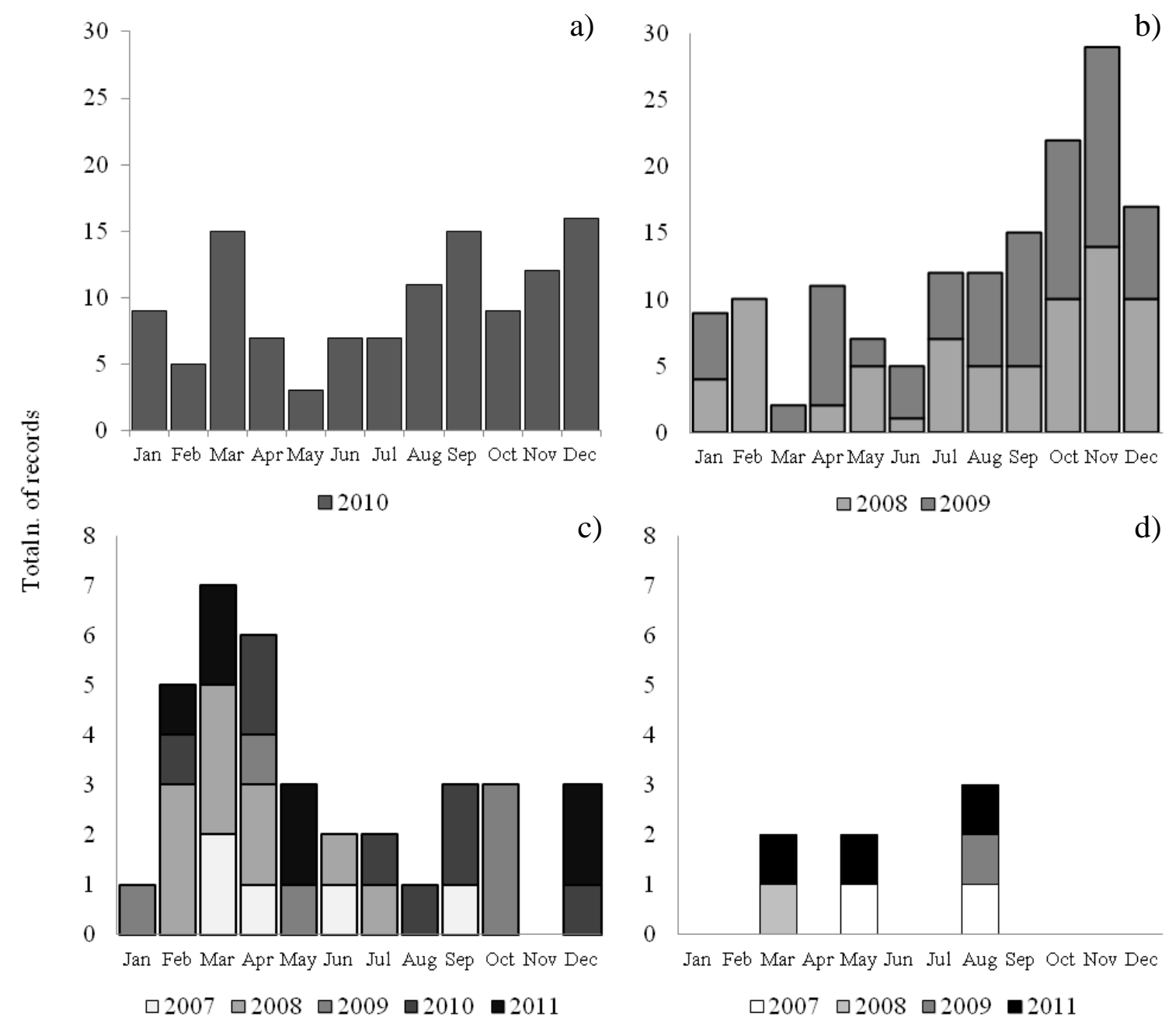

Graph 2. Records for the common sloth (Bradypus variegatus), by month and year in a) CETAS-AL Screening Centre for Wild Animals from Alagoas; b) CETAS-PE - Screening Centre for Wild Animals from Pernambuco (*Xavier et al. 2010); c) DEPAVE-SP - Faunal Division from São Paulo (only data from 2007 to 2011 is depicted to facilitate the direct comparison with the data available from the other facilities), and d) CETAS-CE - Screening Centre for Wild Animals from Ceará.

Overall, the northeastern CETAS (CETAS-AL and CETAS-PE) recorded far more individuals by year than the southern (DEPAVE-SP), and the northern (CETAS-CE) facilities (Graph 1). These differences can be attributed to a combination of the relative amount of area under the care of the agencies, and to its degree of protection. Currently, Alagoas sustains only about 150 thousand ha of Atlantic forest remnants, representing 5\% of the total state area 
(Fundação SOS Mata Atlântica \& INPE 2011). Yet, only 0.18\% of Alagoas constitutes protected area, being the least protected federal state represented in the data (IBGE 2011). On average, CETAS-PE seems to receive half of the individuals by year compared to CETAS-AL. It has only more 80 thousand ha of Atlantic forest remnants than Alagoas (Fundação SOS Mata Atlântica \& INPE 2011). However this area corresponds to a smaller percentage of the state (around 2\%), and has more protected area than Alagoas (about 4.4\%; IBGE 2011). DEPAVESP received only eight common sloths by year, on average, despite São Paulo has the biggest area of Atlantic forest remnants (more than 2.6 million ha), corresponding to $11 \%$ of the total state area, with the larger absolute and relative amount of protected area (Fundação SOS Mata Atlântica \& INPE 2011; IBGE 2011). Thus, despite the amount of forested area in the surroundings of the agencies, likely the habitat protection level and rate of deforestation led to the different amounts of records reported in each facility. Ceará represents a different case, because its predominant natural habitat is Caatinga, a savannah-like biome. Remnants of Atlantic forest represent only about $1 \%$ of the total federal state (Fundação SOS Mata Atlântica \& INPE 2011). This seems to be the main reason for the limited numbers of common sloth individuals arriving this agency.
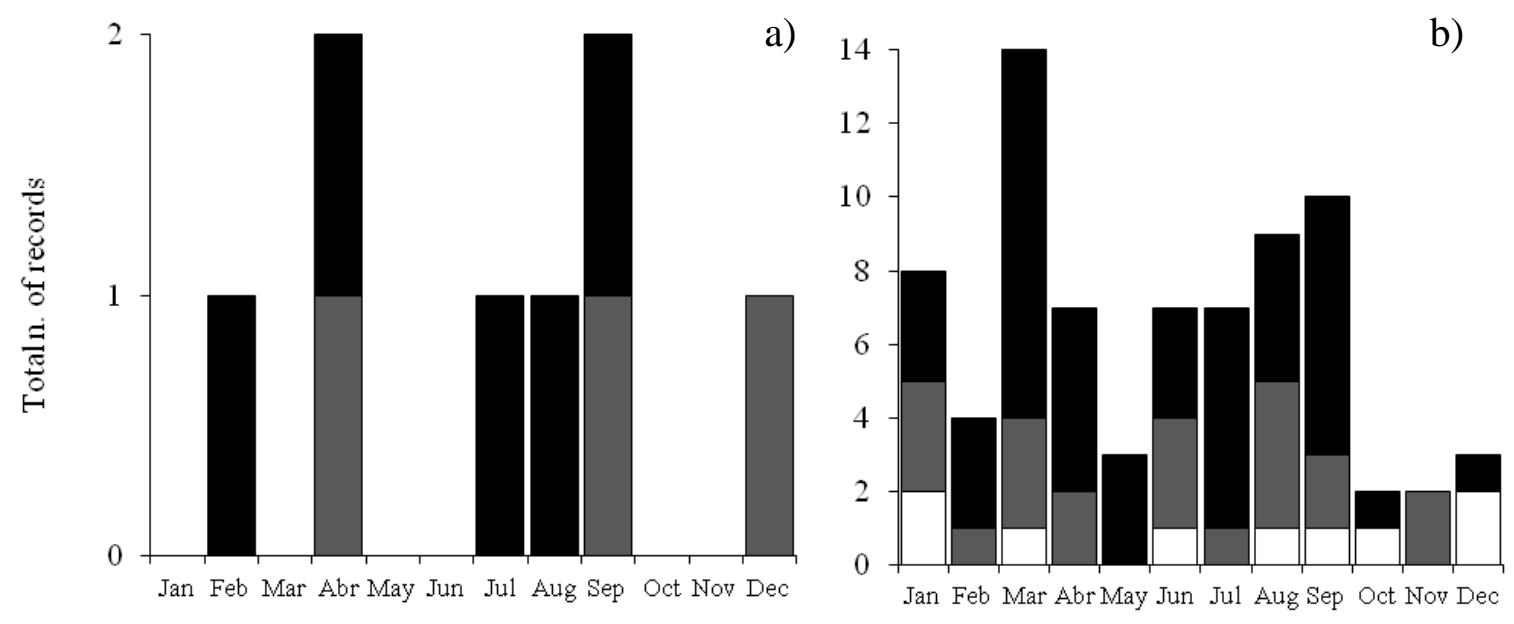

Graph 3. Total available age class records for the common sloth (Bradypus variegatus) in a) DEPAVE-SP - Faunal Division from São Paulo, and b) CETAS-AL - Screening Centre for Wild Animals from Alagoas. White - offsprings; Grey - juveniles; Black - adults.

Graph 1 also depicts local year-to-year differences in the amount of arrivals recorded. This might reflect natural population characteristics such as its structure and dynamics, but human interference cannot be excluded. On one hand, these differences seem not to be due to annual local climatic variations, namely temperature, insolation, precipitation and humidity (INMET 2011). However, Graphs 2 to $4 \mathrm{~b}$ show differences in fluctuation trends along the year. A monthby-month analysis shows that DEPAVE-SP seems to receive more individuals during March, April and December (Graphs 4a, b). These months are included in the rainy and warmer season 
in southeastern Brazil (INMET 2011). Similar trend, although with smaller frequency, occurred in CETAS-CE, reporting arrivals during the beginning (March) and end (August) of the rainy season (Graph 2a). In the northern Brazil this corresponds to the colder months, although the temperature range is smaller and overall higher than in the south (INMET 2011). On another hand, a different trend seems to be predominant in the northeastern CETAS (Graphs $2 \mathrm{~b}$ and 2c). CETAS-PE and CETAS-AL received more animals during the dry season, from September until March. In these cases, both annual (for CETAS-PE) and monthly (for both CETAS-PE and CETAS-AL) increases in the number of records seem to be associated with an increase in local tourism (EMBRATUR 2013; reports from 2005 to 2011). In Colombia, sloths' illegal trade is rising, and tourists are an important fraction of the sloths' buyers (Moreno \& Please 2006). This activity was not quantified in Brazil, but keeping animals in captivity, and selling photographs of tourists holding it, is common practice in northeastern Brazil (Superina et al. 2010). Our data, although not conclusive, highlight the need for further investigation on this interaction.

Differences between sexes were neither statistically significant for the DEPAVE-SP larger dataset ( $p=0,692$; Graph $4 \mathrm{~d}$ ), nor detected in CETAS-AL. These data may reflect natural population demography. If so, it would be in agreement with studies reporting common sloths' sex ratio close to 1:1 (Queiroz 1995; Ballesteros et al. 2009). Regarding age class, adults were more frequent than juveniles and offspring in both DEPAVE-SP and CETAS-AL (Graph 3), and this predominance was statistically significant for the DEPAVE-SP full dataset $(p=0,000)$. Noteworthy, offspring arrived to CETAS-AL during all the year, approximately with the same frequency. This might indicate the constant presence of offspring in nature. On one hand, Bezerra et al. (2008) reported a common sloth copulation event during the rainy season in the northeast, although according to Taube's et al. (2001) review, this is the species births' season. Thus it is possible that the less marked temperature range and/or the warmer temperature in this region favor the extension of the breeding season. On another hand, tourism and illegal trade influences, particularly the preference for offspring sloth pets (Moreno \& Plese 2006), cannot be ruled out to have biased these records. Moreover, data collected by DEPAVE-SP during Parque da Luz management activities, supports the rainy season as the birth season for the common sloth within southeastern BAF. A birth was registered in December 2006, and another one in February 2008; and a pregnant female was caught in August 1994.

Howsoever, offspring are a major worry in these facilities. About a half of the offspring that arrived to the centers eventually died. Overall, only $19.2 \%$ (51 out of 266) of the destiny records reported refers to dead animals; $15.8 \%$ died while in the facilities and $3.38 \%$ already arrived dead. Sloths' husbandry, and particularly common sloth's, it is not fully developed yet (Superina et al. 2008). Food requirements are difficult to be addressed because individuals are quite specialists, behavior passed from mother to offspring (Queiroz 1995; Soares \& Carneiro 2002; Urbani \& Bosque 2007). So each offspring has individual food preferences, making 
difficult to maintain these animals properly fed while in captivity. Nevertheless CETAS-AL has made progresses, maintaining an offspring for more than four months in captivity (Silva et al. 2013).

a)

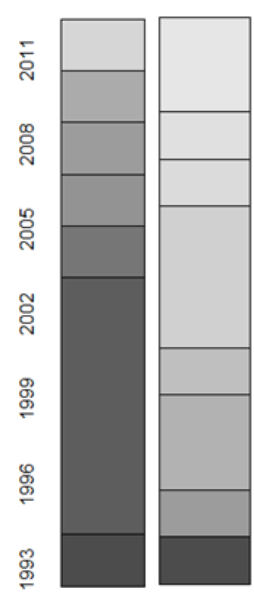

Jan

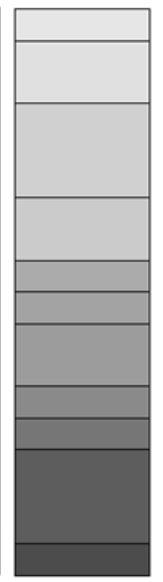

Mar

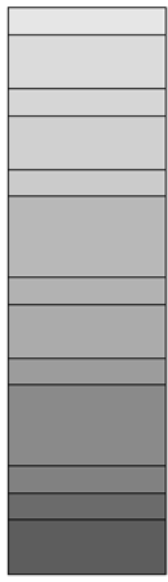

Apr

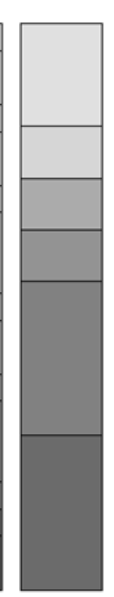

May

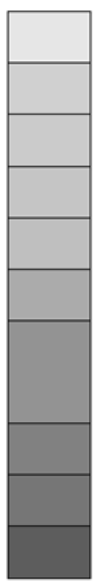

Jun

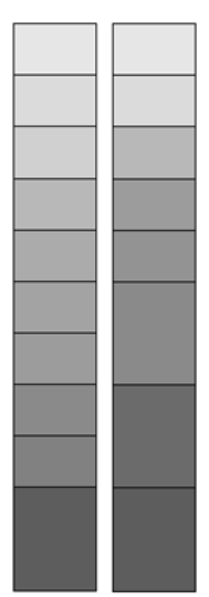

Jul

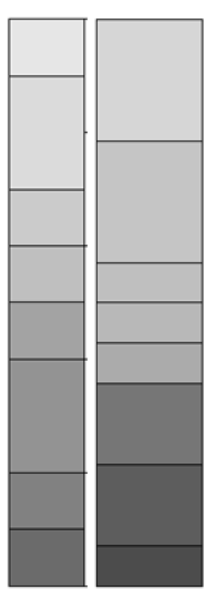

Oct

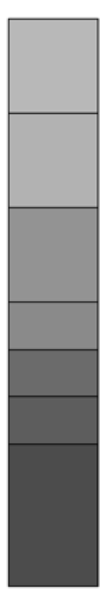

Nov

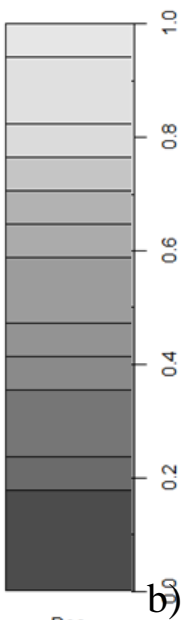

Dec
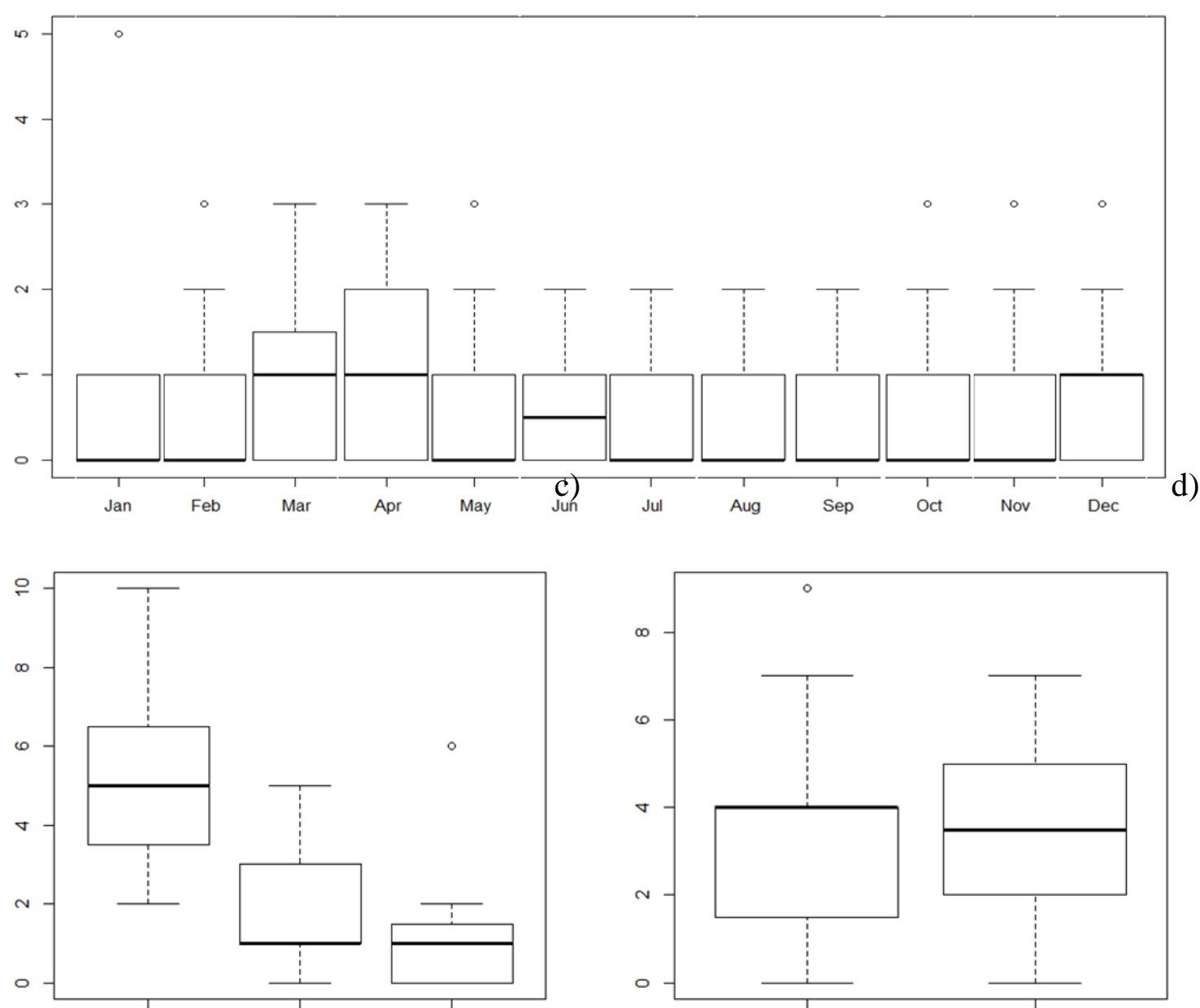

Graph 4. Records for the Jcommon sloth (Bradypus variegatus) in DEPAVE-SP - FaunahDivision from São Paulo. a) Plot of the records depicting seasonality by year and by month. Bars' width represents relative frequency of the records by month. b) Box plot of the dataset, depicting monthly means, standard deviations and total variations. c) Box plot of the data by age class (A - adults; J - juveniles; $\mathrm{O}-$ offspring). d) Box plot of the data by sex class ( $\mathrm{F}-$ females; $\mathrm{M}$ - males). 
From the reported dead animals, even though all individuals with visible injuries from electric shocks were already dead when collected (Table 1), these accidents represent only $7.8 \%$ of the cause of dead registered. Xavier et al. (2010) highlighted accidents by electric shocks, without presenting data from other types of accidents with common sloths. Thus, although far more frequent and less lethal in Pernambuco than in the other regions, our data indicate that electric shocks are not the greatest anthropogenic threat to the common sloth. Falls were pointed out by Ballesteros et al. (2009) as the main reason for animals' mortality in the Viento Solar Natural Reserve, Colombia. The authors did not quantify this evidence, but $31 \%$ of the animals with history of fall died or arrived dead in DEPAVE-SP facilities. This was the second main reason for animals' arrival in this centre, and was $27 \%$ of the times the cause of dead registered. Only three individuals' dead was attributed to road kill (about $6 \%$ of all the obits), but roads were a much more important menace. The majority of animals arriving the facilities was found crossing or close to streets, highways, and railway tracks. This close proximity with roads constitutes a problem due to the animals' lack of ability to quickly move while in the ground.

Table 1. Data available on accidents and menaces to the common sloth registered. *Corresponds to unavailable or unclear menaced record.

DEPAVE-SP CETAS-AL

\begin{tabular}{ccc}
\hline Fall & 45 & - \\
Electric shock & 4 & - \\
Roads & 37 & 36 \\
Dogs & 3 & - \\
Others* $^{*}$ & 72 & 80 \\
\hline
\end{tabular}

Finally, DEPAVE-SP also recorded weight for 94 adult animals (59 males and 33 females). Common sloth males weighted $4.90 \mathrm{~kg}( \pm 0.819)$ and females $4.66 \mathrm{~kg}( \pm 0.906)$. The amount of animals measured (the higher number ever analyzed in only one study), and the statistical significance test result $(p=0.904)$, give us confidence to discard the common sloth sexual size dimorphism, found for other Bradypus species (Lara-Ruiz \& Chiarello 2005). We can conclude that common sloth adults in southern AF weight on average $4.8 \mathrm{~kg}$, varying from 2.5 to $6.5 \mathrm{~kg}$. This measure is similar to that found for Nicaraguan and Panamanian specimens (Anderson \& Handley 2001; Genoways \& Timm 2003).

Although less frequently, the CETAS also registered other Xenarthrans during the period recorded, namely two Cyclopes didactylus in CETAS-AL; 12 Tamandua tetradactyla in CETAS-AL and 22 in CETAS-CE, among them nine offspring; five Euphractus sexcinctus in CETAS-AL and 44 in CETAS-CE; two Dasypus novemcinctus in CETAS-CE (in 2007 and 2010), and even one individual of the vulnerable Tolypeutes tricinctus species was recorded in 
CETAS-CE in 2008 (Superina \& Abba 2010). Although the origin of the individuals is not always clear, these records are also useful for evidencing the geographic distribution of the species.

\section{Conclusion}

Decades of records on the common sloth collected by governmental facilities for wildlife add evidences on the birth period of the species within BAF, and its major menaces, namely important signs of tourism influencing animals' arrival to the CETAS. Furthermore, new data regarding the weight of individuals within AF could be collected. This example, confirms that empowering the governmental centers for wildlife with sufficient human resources, namely with the establishment of long-term collaborations with universities; synchronize activities, knowledge-sharing and experiences among centers will improve work, encourage scientific production, and increase biological knowledge on Brazilian wildlife.

\section{Acknowledgements}

Authors would like to thank to all the CETAS and DEPAVE-SP staff, and their collaborators, namely Fire and Police Departments, health and environmental institutions, and civilians, who have been collecting animals and data across the years. S.M. Silva was supported by a Foundation for Science and Technology PhD grant (SFRH/BD/40638/2007). N. MoraesBarros were supported by CAPES. J. S. Morgante was granted with a research award from FAPESP (08/52207-0).

\section{References}

Anderson, R. P. \& C. O. Handley. 2001. A new species of three-toed sloth (Mammalia: Xenarthra) from Panama, with a review of the genus Bradypus. Proceedings of the Biological Society of Washington 114: 1-33.

Ballesteros, J., K. Reyes \& J. Racero. 2009. Estructura poblacional y etología de Bradypus variegatus en fragmento de bosque seco tropical, Córdoba - Colombia. Revista MVZ Córdoba 14: 1812-1819.

Barros, A. S. 2004. Levantamento e classificação das espécies recolhidas ao centro de triagem de animais silvestres do Instituto Brasileiro do Meio Ambiente e dos Recursos Naturais Renováveis em Recife-Pernambuco. Monography, Universidade Federal Rural de Pernambuco, Recife. 33 pp.

Bezerra, B. M., A. da S. Souto, L. Halsey \& N. Schiel. 2008. Observation of brown-throated three-toed sloths: mating behaviour and the simultaneous nurturing of two young. Journal of Ethology 26: 175-178. 
Britton, S. W. 1941. Form and function in the sloth. The Quarterly Review of Biology 16: 13-34.

Britton, S. W. \& W. E. Atkinson. 1938. Poikilothermism in the Sloth. Journal of Mammalogy 19: 94-99.

Chiarello, A., N. Moraes-Barros \& T. Plese. 2011. Bradypus variegatus. In: IUCN 2012. IUCN Red List of Threatened Species. Version 2012.2. www.iucnredlist.org. Downloaded on 23 March 2013.

EMBRATUR. 2013. Instituto Brasileiro de Turismo. Secretaria Nacional de Políticas de $\begin{array}{llll}\text { Turismo do Ministério do Brasília. } & \text { Turismo, }\end{array}$ http://www.dadosefatos.turismo.gov.br/dadosefatos/anuario Downloaded on 23 March 2013.

Fundação SOS Mata Atlântica \& INPE. 2011. Atlas dos remanescentes florestais da Mata Atlântica período 2008-2010. Fundação SOS Mata Atlântica and Instituto Nacional de Pesquisas Espaciais (INPE) 120 pp.

Garla, R. C., E. Z. F. Setz \& N. Gobbi. 2001. Jaguar (Panthera onca) food habits in Atlantic rain forest of southeastern Brazil. Biotropica 33: 691-696.

Genoways, H. H. \& R. M. Timm. 2003. The Xenarthrans of Nicaragua. Journal of Neotropical Mammalogy 10: 231-253.

IBGE. 2011 Instituto Brasileiro de Geografia e Estatística; Ministério do Meio Ambiente. Mapa de Unidades de Conservação e Terras Indigenas na Área de Aplicação da Lei da Mata Atlântica. http://www.mma.gov.br/biomas/mata-atlantica/mapa-de-ucs-e-terras-indigenas. Downloaded on 23 March 2013.

INMET. 2011. Instituto Nacional de Meteorologia; Ministério da Agricultura, Pecuária e Abastecimento. http://www.inmet.gov.br Downloaded on 23 March 2013.

Lara-Ruiz, P. \& A. G. Chiarello. 2005. Life-history traits and sexual dimorphism of the Atlantic forest maned sloth Bradypus torquatus (Xenarthra: Bradypodidae). Journal of Zoology 267: 63-73.

Moraes-Barros, N., J. A. Silva, C. Y. Miyaki \& J. S. Morgante. 2006. Comparative phylogeography of the Atlantic forest endemic sloth (Bradypus torquatus) and the widespread three-toed sloth (Bradypus variegatus) (Bradypodidae, Xenarthra). Genetica 126: 189-198.

Moraes-Barros, N., C. Y. Miyaki \& J. S. Morgante. 2007. Identifying management units in non-endangered species: the example of the sloth Bradypus variegatus Schinz, 1825. Brazilian Journal of Biology 67: 829-837.

Moreno, S. \& T. Plese. 2006. The illegal traffic in sloths and threats to their survival in Colombia. Edentata 7: 10-18.

Mühlbauer, M., D. P. Duarte, D. P. Gilmore \& C. P. Costa. 2006. Fecal estradiol and progesterone metabolite levels in the three-toed sloth (Bradypus variegatus). Brazilian Journal of Medical and Biological Research 39: 289-295. 
Myers, N., R. A. Mittermeier, C. G. Mittermeier, G. A. da Fonseca \& J. Kent. 2000. Biodiversity hotspots for conservation priorities. Nature 403: 853-858.

Nagy, K. A. \& G. G. Montgomery. 1980. Field metabolic rate, water flux, and food consumption in three-toed sloths (Bradypus variegatus). Journal of Mammalogy: 465-472.

Noss, A. J., R. L. Cuéllar, E. Cuéllar, S. F. Vizcaíno \& W. J. Loughry. 2008. Exploitation of xenarthrans by the Guaraní-Isoseño indigenous people of the Bolivian Chaco. Pp. 244-254 in: The biology of the Xenarthra (S. Vizcaíno \& W. Loughry, eds.). University Press of Florida, Gainesville.

Peres, C. A. 2000. Effects of subsistence hunting on vertebrate community structure in Amazonian forests. Conservation Biology 14: 240-253.

Phillips, S. J., R. P. Anderson \& R. E. Schapire. 2006. Maximum entropy modeling of species geographic distributions. Ecological Modelling 190: 231-259.

Porto, J. 2009. Projeto Cetas-Brasil: foco na gestão da fauna silvestre. Revista IBAMA 4: 14-18.

Queiroz, H. L. 1995. Preguiças e guaribas: os mamíferos folívoros arborícolas do Mamirauá. Conselho Nacional de Desenvolvimento Científico e Tecnológico, Diretoria de Unidades de Pesquisa Sociedade Civil Mamirauá, Brasília. 176 pp.

R Development Core Team. 2008. R: A language and environment for statistical computing. R Foundation for Statistical Computing, Vienna, Austria. ISBN 3-900051-07-0, URL http://www.R-project.org.

Rocha-Mendes, F., R.P.D. Napoli \& S.B. Mikich. 2006. Manejo, reabilitação e soltura de mamíferos selvagens. Arquivos de Ciências Veterinárias e Zoologia da Unipar 9: 105-109.

Silva, T. L., I. N. dos Santos, M. da. S. Belluci \& S. M. Silva. 2013. Relato de caso de técnicas em cativeiro para reintegração de filhote de Bradypus variegatus (Schinz, 1825) in XVIII Encontro de Zoologia do Nordeste, Maceió, Alagoas, Brasil.

Soares, C. A. \& R. S. Carneiro. 2002. Social behavior between mothers x young of sloths Bradypus variegatus Schinz, 1825 (Xenarthra: Bradypodidae). Brazilian Journal of Biology 62: 249-252.

Sunquist, M. E. \& G. G. Montgomery. 1973. Activity patterns and rates of movement of two-toed and three-toed sloths (Choloepus hoffmanni and Bradypus infuscatus). Journal of Mammalogy 54: 946-954.

Superina, M. \& A.M. Abba. 2010. Tolypeutes tricinctus. In: IUCN 2012. IUCN Red List of Threatened Species. Version 2012.2. www.iucnredlist.org.

Superina, M., F. Miranda, T. Plese, S. F. Vizcaíno \& W. J. Loughry. 2008. Maintenance of Xenarthra in captivity. Pp. 232-243 in: The Biology of the Xenarthra (S. Vizcaíno \& W. Loughr, eds.). University Press of Florida, Gainesville. 
Superina, M., T. Plese, N. Moraes-Barros \& A. M. Abba. 2010. The 2010 Sloth Red List Assessment. Edentata 11: 115-134.

Taube, E., J. Keravec, J. C. Vié \& J. M. Duplantier. 2001. Reproductive biology and postnatal development in sloths, Bradypus and Choloepus: review with original data from the field (French Guiana) and from captivity. Mammal Review 31: 173-188.

Urbani, B. \& C. Bosque. 2007. Feeding ecology and postural behaviour of the three-toed sloth (Bradypus variegatus flaccidus) in northern Venezuela. Mammalian Biology - Zeitschrift für Säugetierkunde 72: 321-329.

Vaughan, C., O. Ramírez, G. Herrera \& R. Guries. 2007. Spatial ecology and conservation of two sloth species in a cacao landscape in Limón, Costa Rica. Biodiversity and Conservation 16: 2293-2310.

Voirin, J. B., R. Kays, M. D. Lowman \& M. Wikelski. 2009. Evidence for three-toed sloth (Bradypus variegatus) predation by spectacled owl (Pulsatrix perspicillata). Edentata 8: 15-20.

Wang, E. 2002. Diets of ocelots (Leopardus pardalis), margays (L. wiedii), and oncillas ( $L$. tigrinus) in the Atlantic rainforest in southeast Brazil. Studies on Neotropical Fauna and Environment 37: 207-212.

Xavier, G. A. A., T. D. Amora, Y. M. Valença \& M. C. C. Cabral. 2010. Apreensões de preguiças Bradypus variegatus Schinz, 1825 e casos de acidentes com choques elétricos envolvendo estes animais na mesorregião metropolitana do Recife, Pernambuco. Pp. 301-308 in A Conferência da Terra: Aquecimento global, sociedade e biodiversidade (G. Seabra, J. A. N. Silva \& I. T. L. Mendonça, eds.), João Pessoa, Paraíba, Brazil. 


\section{CAPítulo 8. Discussã̃o Geral e Conclusões}

O presente trabalho teve como principal objetivo a descrição e análise dos padrões de diversidade genética nuclear das populações de preguiça comum da Mata Atlântica brasileira. Geralmente, inúmeros processos estão envolvidos na distribuição da diversidade genética de uma espécie, nomeadamente fatores relacionados com a história evolutiva do habitat em que ocorre, bem como aspetos intrínsecos à sua biologia.

Assim, começou-se por fazer uma meta-análise da distribuição de vertebrados terrestres, estritamente florestais, na Mata Atlântica, para investigar os padrões gerais encontrados no bioma. Dados genéticos e morfológicos anteriormente publicados foram analisados, incluindose dados sobre a preguiça comum (Bradypus variegatus) e a preguiça de coleira (B. torquatus; Moraes-Barros et al. 2002, 2006, 2007; Lara-Ruiz et al. 2008). Neste capítulo, exploraram-se também os mecanismos que estariam na base dos padrões encontrados. Deste trabalho concluise a complexidade da Mata Atlântica, contrariando-se a hipótese da divisão do bioma em somente dois-componentes (Costa et al. 2000) e propondo-se nove componentes bióticos de vertebrados terrestres, estritamente florestais. A heterogeneidade local e regional verificada parece dever-se a inúmeros e distintos processos climáticos, orográficos e biológicos, atuando de diferente modo em cada componente. Assim, parece ser vantajoso recorrer a estudos de finaescala de modo a diminuir os fatores envolvidos no processo de diversificação na Mata Atlântica. Além disso, a necessidade do aumento de parcerias entre a comunidade científica que se dedica ao estudo da Mata Atlântica foi recomendada, de modo a fomentar a troca de dados e opiniões e facilitar o seu estudo. O Capítulo 2 é já uma das referências que elucida a história evolutiva da América do Sul (Turchetto-Zolet et al. 2012), e tem auxiliado o estudo filogeográfico de vertebrados na Mata Atlântica (Gehara 2013). Especificamente em relação à preguiça comum, as conclusões do Capítulo 2 ressaltam que os padrões de distribuição da diversidade genética da espécie na Mata Atlântica provavelmente também não seriam facilmente nem simplesmente explicados. Os estudos genéticos dos Capítulos 3 e 4 corroboraram esta afirmação e concluem que, também para o estudo da espécie, os estudos de fina-escala contribuem para a definição dos processos históricos e demográficos que influem nos seus padrões de diversidade genética.

Os resultados e inferências anteriores das análises de DNA mitocondrial e fingerprinting (Moraes-Barros et al. 2002, 2006, 2007) foram comprovados e alargados para a porção nuclear do genoma da preguiça comum. Nomeadamente, as análises de DNA nuclear suportam a diferenciação entre as populações Amazônicas e Atlânticas de preguiça comum; a existência de três populações distintas na Mata Atlântica, entendidas como Unidades de Manejo; a ligação pelo nordeste brasileiro entre os dois biomas e a colonização da Mata Atlântica pela preguiça comum de norte para sul do bioma, provavelmente realizada através de pulsos de expansão e 
isolamento. Além disso, a baixa diversidade genética de marcadores geralmente muito variáveis como os microssatélites, associada à subestruturação populacional, à ausência de bottleneck intra populacional, à biologia da espécie, e às evidências extrínsecas de instabilidade climática e perda de floresta suportam a formação de um sistema da meta-populações de preguiça comum na Mata Atlântica. Concretamente, cada população do bioma deve ser considerada como uma metapopulação isolada das demais por fatores históricos e perda de habitat atual. Esta organização / processo raramente evidenciado no bioma, potencialmente poderia explicar os padrões de diversidade genética de outras espécies do bioma.

O desconhecimento da biologia e etologia da preguiça comum, particularmente na Mata Atlântica (revisto por Superina et al. 2008; Hayssen 2010; Superina et al. 2010), alertam para a necessidade de um aumento de estudos destas populações. Os capítulos 6 e 7 demonstraram essa escassez e colmataram algumas lacunas.

Nomeadamente, no capítulo 6 conclui-se que os indivíduos de preguiça comum na Mata Atlântica podem interagir pacificamente, mas que os seus comportamentos não estão ainda totalmente esclarecidos. Para elaboração destes relatos de campo, sentiu-se a falta de uma padronização da descrição de movimentos e posturas da espécie. Assim sendo, propôs-se uma tabela padronizada de posturas e atividades de preguiça comum em habitat natural. A semelhança dos registros comportamentais de outras espécies do gênero Bradypus sugere que esta tabela poderá ser utilizada também no seu estudo (Chiarello et al. 2004; Lara-Ruiz \& Chiarello 2005; Dias et al. 2009).

No Capitulo 7, dados novos relativos à biologia da espécie na Mata Atlântica foram incluídos. Concretamente confirmaram-se a época reprodutiva e a ausência de dimorfismo sexual na Mata Atlântica, e identificaram-se ameaças antrópicas no bioma, para além da já mencionada fragmentação / perda de habitat (Chiarello et al. 2011). A colaboração dos centros governamentais e estaduais para a vida selvagem foi fundamental no decorrer de todo o trabalho pela cedência de amostras biológicas de espécimes de preguiça comum e preguiça de coleira, mas o último capítulo exemplifica a maior contribuição que estas instituições podem dar ao estudo da fauna brasileira. Estas instituições conseguem recolher dados biológicos numa escala temporal alargada que dificilmente seriam conseguidos através de trabalhos de campo.

Esta tese constitui ainda o primeiro estudo genético da preguiça anã. Tal como se esperava, devido à história recente de colonização de uma pequena ilha do Panamá seguida de especiação (Anderson \& Handley 2001, 2002), descreveram-se níveis de baixa diversidade genética e encontraram-se sinais de gargalo populacional na única população de preguiça anã. Esta população apresenta níveis de diversidade genética inferiores à população que lhe deu origem, a população de preguiça comum do continente. No entanto, estes níveis são mais elevados do que aqueles encontrados na população de preguiça comum do sul da Mata Atlântica (Capítulos 3 e 5). O Capítulo 5 demonstrou que a hierarquização da diversidade genética entre populações de 
mamíferos varia consoante o número de microssatélites utilizado, o seu grau de polimorfismo, o estimador de polimorfismo do locus e as populações avaliadas. Porém estas relações entre a diversidade genética da preguiça anã e as duas populações de preguiça comum mantiveram-se estáveis em todas as análises.

Finalmente, o Capítulo 5 teve um cariz mais metodológico e técnico precisamente para avaliar a robustez das comparações de diversidade genética entre diferentes populações, quando pequenas baterias de microssatélites mais polimórficos (cerca de 10 ou 20 marcadores) seriam utilizadas. Para além do mencionado no parágrafo anterior, neste capítulo concluiu-se que a escolha de marcadores com base no seu grau de polimorfismo enviesa as estimativas de diversidade genética superestimando-as. A prática comum de escolha de marcadores com base no seu grau de polimorfismo deve ser evitada (Heller et al. 2008; Nikolic et al. 2009; Kleven et al. 2012). Igualmente, a descrição de todos os marcadores descritos e amplificados numa espécie devem ser publicados, independentemente do seu grau de polimorfismo, principalmente para espécies cujo conhecimento ainda é insipiente. Isto porque espécies estruturadas e com diferentes níveis de diversidade genética distintos entre as suas populações podem apresentar marcadores com níveis de polimorfismo muito díspares em cada população. Assim, a diversidade genética das populações de mamíferos deve ser estimada com base em marcadores aleatoriamente escolhidos, com um limite mínimo de 40 marcadores e detalhamento do conhecimento existente sobre as populações ou taxa avaliados.

Apesar da preguiça comum ser considerada não-ameaçada (Chiarello et al. 2011), este trabalho identifica a necessidade de medidas de conservação da preguiça comum na Mata Atlântica devido:

i) à diferenciação das populações Attânticas em relação às Amazônicas, com presença de alelos únicos na Mata Atlântica;

ii) à estruturação populacional, com indícios de baixo fluxo gênico entre populações Atlânticas e de endogamia em cada uma das populações, suportando-se diferentes unidades de manejo (Moraes-Barros et al. 2007);

iii) aos baixos níveis de diversidade genética nuclear encontrados nas populações de preguiça comum da Mata Atlântica. Sequências de DNA nuclear codificante e não-codificante, bem como marcadores do tipo microssatélite, mostraram-se pouco variáveis nas populações de preguiça comum do bioma, à semelhança do já reportado para DNA mitocondrial e fingerprinting (Moraes-Barros et al. 2002, 2006, 2007). Particularmente a diversidade genética da população Atlântica do sul é menor do que a registrada em populações ameaçadas de preguiça de coleira e de preguiça anã (Anderson et al. 2011);

iv) às evidências de requerimentos biológicos distintos dessas populações, pela perceção de épocas reprodutivas diferentes; 
v) i) à elevada complexidade local e regional de processos intervenientes nos padrões de diversidade genética da preguiça comum;

vi) à forte influência antrópica, quer por um grande impacto do desmatamento, quer pelo fluxo turístico sazonal.

Assim redefinem-se as unidades de manejo anteriormente sugeridas, propõe-se a utilização da preguiça comum como espécie bandeira em ações para a sua conservação, da Mata Atlântica e de outras espécies de preguiça e incentiva-se a realização de mais estudos genéticos (com aumento de amostragem dentro e fora das populações aqui analisadas) e principalmente reforçase a necessidade da elaboração de estudos ecológicos e etológicos.

\section{Referências}

Anderson RP, Handley CO. 2001. A new species of three-toed sloth (Mammalia: Xenarthra) from Panama, with a review of the genus Bradypus. Proceedings of the Biological Society of Washington 114: 1-33.

Anderson RP, Handley CO, Jr. 2002. Dwarfism in insular sloths: biogeography, selection, and evolutionary rate. Evolution 56: 1045-58.

Anderson RP, Moraes-Barros N, Voirin B. 2011. Bradypus pygmaeus. In: IUCN 2012. IUCN Red List of Threatened Species. Version 2012.2. www.iucnredlist.org. Downloaded on 15 November 2012.

Chiarello A, Moraes-Barros N, Plese, T. 2011. Bradypus variegatus. In: IUCN 2012. IUCN Red List of Threatened Species. Version 2012.2. www.iucnredlist.org. Downloaded on 23 March 2013.

Chiarello AG, Chivers DJ, Bassi C, Maciel MAF, Moreira LS, Bazzalo M. 2004. A translocation experiment for the conservation of maned sloths, Bradypus torquatus (Xenarthra, Bradypodidae). Biological Conservation 118: 421-430.

Costa LP, Leite YLR, Fonseca GAB, Fonseca MT. 2000. Biogeography of South American forest mammals: Endemism and diversity in the Brazilian Atlantic forest. Biotropica 32: 872881.

Dias B, Dias dos Santos L, Lara-Ruiz P, Cassano C, Pinder L, Chiarello A. 2009. First observation on mating and reproductive seasonality in maned sloths Bradypus torquatus (Pilosa: Bradypodidae). Journal of Ethology 27: 97-103.

Gehara MCM. 2013. Molecular analysis and phylogeography of neotropical amphibians Fakultät für Lebenswissenschaften. Braunschweig, Lower Saxony, Germany: Technischen Universität Carolo-Wilhelmina zu Braunschweig. 96.

Hayssen V. 2010. Bradypus variegatus (Pilosa: Bradypodidae). Mammalian Species 42: 1932. 
Heller R, Lorenzen ED, Okello JB, Masembe C, Siegismund HR. 2008. Mid-Holocene decline in African buffalos inferred from Bayesian coalescent-based analyses of microsatellites and mitochondrial DNA. Molecular Ecology 17: 4845-58.

Kleven O, Hallström BM, Hailer F, Janke A, Hagen SB, Kopatz A, Eiken HG. 2012. Identification and evaluation of novel di- and tetranucleotide microsatellite markers from the brown bear (Ursus arctos). Conservation Genetics Resources 4: 737-741.

Lara-Ruiz P, Chiarello AG. 2005. Life-history traits and sexual dimorphism of the Atlantic forest maned sloth Bradypus torquatus (Xenarthra: Bradypodidae). Journal of Zoology 267: 6373.

Lara-Ruiz P, Chiarello AG, Santos FR. 2008. Extreme population divergence and conservation implications for the rare endangered Atlantic Forest sloth, Bradypus torquatus (Pilosa: Bradypodidae). Biological Conservation 141: 1332-1342.

Moraes-Barros N, Miyaki CY, Morgante JS. 2007. Identifying management units in nonendangered species: the example of the sloth Bradypus variegatus Schinz, 1825. Brazilian Journal of Biology 67: 829-37.

Moraes-Barros N, Morgante JS, Miyaki CY. 2002. Genetic diversity in different populations of sloths assessed by DNA fingerprinting. Brazilian Journal of Biology 62: 503-8.

Moraes-Barros N, Silva JA, Miyaki CY, Morgante JS. 2006. Comparative phylogeography of the Atlantic forest endemic sloth (Bradypus torquatus) and the widespread three-toed sloth (Bradypus variegatus) (Bradypodidae, Xenarthra). Genetica 126: 189-98.

Nikolic N, Fève K, Chevalet C, Høyheim B, iquet J. 2009 a. A set of 37 microsatellite DNA markers for genetic diversity and structure analysis of Atlantic salmon Salmo salar populations. Journal of Fish Biology 74: 458-466.

Superina M, Miranda F, Plese T, Vizcaíno SF, Loughry WJ. 2008. Maintenance of Xenarthra in captivity. Pp. 232-243 in: The Biology of the Xenarthra (S. Vizcaíno \& W. Loughr, eds.). University Press of Florida, Gainesville.

Superina M., Plese T, Moraes-Barros N, Abba AM. 2010. The 2010 Sloth Red List Assessment. Edentata 11: 115-134.

Turchetto-Zolet AC, Pinheiro F, Salgueiro F, Palma-Silva C. 2013. Phylogeographical patterns shed light on evolutionary process in South America. Molecular Ecology 22: 11931213. 
Anexos 


\section{CAPÍTULO 2.}

Table S1. Data analyzed in the panbiogeographic approach.

\begin{tabular}{|c|c|c|c|c|c|c|}
\hline \multirow[b]{2}{*}{ Group } & \multicolumn{3}{|c|}{ Martitracks Input } & \multirow[b]{2}{*}{ Locality } & \multirow[b]{2}{*}{ Other Information } & \multirow[b]{2}{*}{ Reference } \\
\hline & $\begin{array}{c}\begin{array}{c}\text { Subgroup } \\
\text { Code }\end{array} \\
\end{array}$ & Lat. & Long. & & & \\
\hline Akodon cursor & $\mathrm{Ac} 1$ & -8.667 & -35.150 & Rio Formoso, PE & & Nogueira \& Fagundes, 2008 \\
\hline Akodon cursor & Ac1 & -15.300 & -39.067 & Una, BA & & Nogueira \& Fagundes, 2008 \\
\hline Akodon cursor & Ac2 & -25.200 & -48.033 & Ariri, SP & & Nogueira \& Fagundes, 2008 \\
\hline Akodon cursor & Ac2 & -22.167 & -48.750 & Boracéia, SP & & Nogueira \& Fagundes, 2008 \\
\hline Akodon cursor & Ac2 & -20.267 & -40.417 & Cariacica, ES & & Nogueira \& Fagundes, 2008 \\
\hline Akodon cursor & Ac2 & -20.600 & -41.200 & Castelo, ES & & Nogueira \& Fagundes, 2008 \\
\hline Akodon cursor & Ac2 & -20.400 & -40.633 & Domingos Martins, ES & & Nogueira \& Fagundes, 2008 \\
\hline Akodon cursor & Ac2 & -24.717 & -47.550 & Iguape, SP & & Nogueira \& Fagundes, 2008 \\
\hline Akodon cursor & Ac2 & -23.367 & -44.833 & Picinguaba, SP & & Nogueira \& Fagundes, 2008 \\
\hline Akodon cursor & Ac2 & -19.917 & -40.600 & Santa Teresa, ES & & Nogueira \& Fagundes, 2008 \\
\hline Akodon cursor & Ac2 & -24.383 & -47.917 & Sete Barras, SP & & Nogueira \& Fagundes, 2008 \\
\hline Bothrops jararaca & $\mathrm{Bj} 1$ & -23.433 & -47.067 & Araçariguama, SP & & Grazziotin et al. 2006 \\
\hline Bothrops jararaca & $\mathrm{Bj} 1$ & -22.117 & -43.200 & Areal, Três Rios, RJ & & Grazziotin et al. 2006 \\
\hline Bothrops jararaca & $\mathrm{Bj} 1$ & -23.117 & -46.550 & Atibaia, SP & & Grazziotin et al. 2006 \\
\hline Bothrops jararaca & $\mathrm{Bj} 1$ & -22.467 & -43.817 & Barra do Pirai, RJ & & Grazziotin et al. 2006 \\
\hline Bothrops jararaca & $\mathrm{Bj} 1$ & -22.167 & -44.400 & Bocaina de Minas, MG & & Grazziotin et al. 2006 \\
\hline Bothrops jararaca & $\mathrm{Bj} 1$ & -22.750 & -41.883 & Búzios, RJ & & Grazziotin et al. 2006 \\
\hline Bothrops jararaca & $\mathrm{Bj} 1$ & -22.483 & -42.650 & Cachoeira de Macacu, RJ & & Grazziotin et al. 2006 \\
\hline Bothrops jararaca & $\mathrm{Bj} 1$ & -21.983 & -42.367 & Cantagalo, RJ & & Grazziotin et al. 2006 \\
\hline Bothrops jararaca & $\mathrm{Bj} 1$ & -20.167 & -42.267 & Caputira, MG & & Grazziotin et al. 2006 \\
\hline Bothrops jararaca & $\mathrm{Bj} 1$ & -23.517 & -46.800 & Carapicuíba, SP & & Grazziotin et al. 2006 \\
\hline Bothrops jararaca & $\mathrm{Bj} 1$ & -23.683 & -47.033 & Caucaia do Alto, SP & & Grazziotin et al. 2006 \\
\hline Bothrops jararaca & $\mathrm{Bj} 1$ & -22.033 & -42.367 & Cordeiro, RJ & & Grazziotin et al. 2006 \\
\hline Bothrops jararaca & Bj1 & -20.367 & -40.667 & Domingos Martins, ES & & Grazziotin et al. 2006 \\
\hline Bothrops jararaca & $\mathrm{Bj} 1$ & -23.650 & -46.833 & Embú, SP & & Grazziotin et al. 2006 \\
\hline Bothrops jararaca & $\mathrm{Bj} 1$ & -22.550 & -43.683 & Eng, Paulo de Frontin, RJ & & Grazziotin et al. 2006 \\
\hline Bothrops jararaca & $\mathrm{Bj} 1$ & -20.367 & -40.667 & Fazenda Santa Maria, ES & & Grazziotin et al. 2006 \\
\hline Bothrops jararaca & $\mathrm{Bj} 1$ & -23.650 & -47.217 & Ibiuna, SP & & Grazziotin et al. 2006 \\
\hline Bothrops jararaca & $\mathrm{Bj} 1$ & -24.017 & -45.767 & Ilha de Alcatrazes, SP & & Grazziotin et al. 2006 \\
\hline Bothrops jararaca & Bj1 & -24.500 & -46.700 & Ilha Queimada Grande, SP & & Grazziotin et al. 2006 \\
\hline Bothrops jararaca & $\mathrm{Bj} 1$ & -19.833 & -43.150 & João Monlevade, MG & & Grazziotin et al. 2006 \\
\hline Bothrops jararaca & $\mathrm{Bj} 1$ & -21.750 & -43.350 & Juiz de Fora, MG & & Grazziotin et al. 2006 \\
\hline Bothrops jararaca & $\mathrm{Bj} 1$ & -23.200 & -46.867 & Jundiaí, SP & & Grazziotin et al. 2006 \\
\hline Bothrops jararaca & $\mathrm{Bj} 1$ & -23.950 & -47.050 & Juquitiba, SP & & Grazziotin et al. 2006 \\
\hline Bothrops jararaca & $\mathrm{Bj} 1$ & -22.650 & -43.033 & Magé, RJ & & Grazziotin et al. 2006 \\
\hline Bothrops jararaca & $\mathrm{Bj} 1$ & -22.917 & -42.817 & Maricá, RJ & & Grazziotin et al. 2006 \\
\hline Bothrops jararaca & Bj1 & -19.217 & -45.967 & Matutina, MG & & Grazziotin et al. 2006 \\
\hline Bothrops jararaca & $\mathrm{Bj} 1$ & -22.667 & -46.683 & Monte Alegre do Sul, SP & & Grazziotin et al. 2006 \\
\hline
\end{tabular}




\begin{tabular}{|c|c|c|c|c|c|c|}
\hline \multirow[b]{2}{*}{ Group } & \multicolumn{3}{|c|}{ Martitracks Input } & \multirow[b]{2}{*}{ Locality } & \multirow[b]{2}{*}{ Other Information } & \multirow[b]{2}{*}{ Reference } \\
\hline & $\begin{array}{c}\text { Subgroup } \\
\text { Code }\end{array}$ & Lat. & Long. & & & \\
\hline Bothrops jararaca & $\mathrm{Bj} 1$ & -22.900 & -43.133 & Niteroi, RJ & & Grazziotin et al. 2006 \\
\hline Bothrops jararaca & $\mathrm{Bj} 1$ & -22.267 & -42.517 & Nova Friburgo, RJ & & Grazziotin et al. 2006 \\
\hline Bothrops jararaca & $\mathrm{Bj} 1$ & -22.150 & -43.283 & PB do Sul, MG & & Grazziotin et al. 2006 \\
\hline Bothrops jararaca & $\mathrm{Bj} 1$ & -18.583 & -46.500 & Patos de Minas, MG & & Grazziotin et al. 2006 \\
\hline Bothrops jararaca & $\mathrm{Bj} 1$ & -23.400 & -46.733 & Perus, SP & & Grazziotin et al. 2006 \\
\hline Bothrops jararaca & $\mathrm{Bj} 1$ & -22.517 & -43.183 & Petrópolis, RJ & & Grazziotin et al. 2006 \\
\hline Bothrops jararaca & Bj1 & -23.700 & -47.400 & Piedade, SP & & Grazziotin et al. 2006 \\
\hline Bothrops jararaca & $\mathrm{Bj} 1$ & -23.200 & -47.517 & Porto Feliz, SP & & Grazziotin et al. 2006 \\
\hline Bothrops jararaca & $\mathrm{Bj} 1$ & -22.800 & -45.450 & Ribeirão Grande, SP & & Grazziotin et al. 2006 \\
\hline Bothrops jararaca & $\mathrm{Bj} 1$ & -22.900 & -43.200 & Rio de Janeiro, RJ & & Grazziotin et al. 2006 \\
\hline Bothrops jararaca & $\mathrm{Bj} 1$ & -20.850 & -43.483 & Rio Espera, MG & & Grazziotin et al. 2006 \\
\hline Bothrops jararaca & $\mathrm{Bj} 1$ & -19.967 & -43.400 & Santa Bárbara, MG & & Grazziotin et al. 2006 \\
\hline Bothrops jararaca & $\mathrm{Bj} 1$ & -21.550 & -42.283 & Santa Cruz da Serra, RJ & & Grazziotin et al. 2006 \\
\hline Bothrops jararaca & $\mathrm{Bj} 1$ & -20.033 & -40.733 & Santa Maria Jetiba, ES & & Grazziotin et al. 2006 \\
\hline Bothrops jararaca & $\mathrm{Bj} 1$ & -21.950 & -42.017 & Santa Maria Madalena, RJ & & Grazziotin et al. 2006 \\
\hline Bothrops jararaca & $\mathrm{Bj} 1$ & -19.933 & -40.583 & Santa Teresa, ES & & Grazziotin et al. 2006 \\
\hline Bothrops jararaca & $\mathrm{Bj} 1$ & -20.783 & -43.683 & Santana do Monte, MG & & Grazziotin et al. 2006 \\
\hline Bothrops jararaca & $\mathrm{Bj} 1$ & -23.450 & -46.917 & Santana do Parnaíba, SP & & Grazziotin et al. 2006 \\
\hline Bothrops jararaca & $\mathrm{Bj} 1$ & -23.700 & -46.533 & São Bernardo do Campo, SP & & Grazziotin et al. 2006 \\
\hline Bothrops jararaca & $\mathrm{Bj} 1$ & -20.800 & -42.267 & São Francisco da Gloria, MG & & Grazziotin et al. 2006 \\
\hline Bothrops jararaca & $\mathrm{Bj} 1$ & -22.833 & -43.067 & São Gonçalo, RJ & & Grazziotin et al. 2006 \\
\hline Bothrops jararaca & $\mathrm{Bj} 1$ & -20.383 & -42.150 & São João do Manhaçu, MG & & Grazziotin et al. 2006 \\
\hline Bothrops jararaca & $\mathrm{Bj} 1$ & -23.533 & -46.617 & $\mathrm{SP}, \mathrm{SP}$ & & Grazziotin et al. 2006 \\
\hline Bothrops jararaca & $\mathrm{Bj} 1$ & -22.000 & -42.917 & Sapucai, RJ & & Grazziotin et al. 2006 \\
\hline Bothrops jararaca & $\mathrm{Bj} 1$ & -23.600 & -46.767 & Taboão da Serra, SP & & Grazziotin et al. 2006 \\
\hline Bothrops jararaca & $\mathrm{Bj} 1$ & -23.950 & -47.483 & Tapiraí, SP & & Grazziotin et al. 2006 \\
\hline Bothrops jararaca & $\mathrm{Bj} 1$ & -24.333 & -50.617 & Telêmaco Borba, PR & & Grazziotin et al. 2006 \\
\hline Bothrops jararaca & $\mathrm{Bj} 1$ & -22.400 & -42.983 & Teresópolis, RJ & & Grazziotin et al. 2006 \\
\hline Bothrops jararaca & $\mathrm{Bj} 1$ & -23.450 & -45.067 & Ubatuba, SP & & Grazziotin et al. 2006 \\
\hline Bothrops jararaca & $\mathrm{Bj} 1$ & -22.233 & -43.700 & Valença, RJ & & Grazziotin et al. 2006 \\
\hline Bothrops jararaca & $\mathrm{Bj} 1$ & -22.967 & -46.983 & Valinhos, SP & & Grazziotin et al. 2006 \\
\hline Bothrops jararaca & $\mathrm{Bj} 1$ & -22.400 & -43.667 & Vassouras, RJ & & Grazziotin et al. 2006 \\
\hline Bothrops jararaca & $\mathrm{Bj} 1$ & -20.300 & -40.300 & Vitória, ES & & Grazziotin et al. 2006 \\
\hline Bothrops jararaca & $\mathrm{Bj} 2$ & -28.983 & -52.017 & Anta Gorda, RS & & Grazziotin et al. 2006 \\
\hline Bothrops jararaca & $\mathrm{Bj} 2$ & -23.233 & -51.667 & Astorga, PR & & Grazziotin et al. 2006 \\
\hline Bothrops jararaca & $\mathrm{Bj} 2$ & -26.917 & -49.100 & Blumenau, SC & & Grazziotin et al. 2006 \\
\hline Bothrops jararaca & $\mathrm{Bj} 2$ & -28.700 & -50.400 & Bom Jesus, RS & & Grazziotin et al. 2006 \\
\hline Bothrops jararaca & $\mathrm{Bj} 2$ & -30.033 & -53.900 & Cachoeira do Sul, RS & & Grazziotin et al. 2006 \\
\hline Bothrops jararaca & $\mathrm{Bj} 2$ & -29.367 & -50.800 & Canela, RS & & Grazziotin et al. 2006 \\
\hline Bothrops jararaca & $\mathrm{Bj} 2$ & -26.183 & -50.383 & Canoinhas, SC & & Grazziotin et al. 2006 \\
\hline Bothrops jararaca & $\mathrm{Bj} 2$ & -24.967 & -53.450 & Cascavel, PR & & Grazziotin et al. 2006 \\
\hline Bothrops jararaca & $\mathrm{Bj} 2$ & -28.933 & -50.650 & Cazuza Ferreira, RS & & Grazziotin et al. 2006 \\
\hline
\end{tabular}




\begin{tabular}{|c|c|c|c|c|c|c|}
\hline \multirow[b]{2}{*}{ Group } & \multicolumn{3}{|c|}{ Martitracks Input } & \multirow[b]{2}{*}{ Locality } & \multirow[b]{2}{*}{ Other Information } & \multirow[b]{2}{*}{ Reference } \\
\hline & $\begin{array}{c}\text { Subgroup } \\
\text { Code }\end{array}$ & Lat. & Long. & & & \\
\hline Bothrops jararaca & $\mathrm{Bj} 2$ & -23.033 & -49.717 & Chavantes, SP & & Grazziotin et al. 2006 \\
\hline Bothrops jararaca & $\mathrm{Bj} 2$ & -26.450 & -49.217 & Corupa, SC & & Grazziotin et al. 2006 \\
\hline Bothrops jararaca & $\mathrm{Bj} 2$ & -25.417 & -49.450 & Curitiba, PR & & Grazziotin et al. 2006 \\
\hline Bothrops jararaca & $\mathrm{Bj} 2$ & -29.350 & -49.850 & Dom Pedro de Alcântara, RS & & Grazziotin et al. 2006 \\
\hline Bothrops jararaca & $\mathrm{Bj} 2$ & -27.050 & -50.050 & Fraiburgo, SC & & Grazziotin et al. 2006 \\
\hline Bothrops jararaca & $\mathrm{Bj} 2$ & -29.367 & -50.867 & Gramado, RS & & Grazziotin et al. 2006 \\
\hline Bothrops jararaca & $\mathrm{Bj} 2$ & -24.183 & -48.533 & Guapiava, SP & & Grazziotin et al. 2006 \\
\hline Bothrops jararaca & $\mathrm{Bj} 2$ & -29.567 & -50.783 & Igrejinha, RS & & Grazziotin et al. 2006 \\
\hline Bothrops jararaca & $\mathrm{Bj} 2$ & -26.483 & -49.100 & Jaraguá do Sul, SC & & Grazziotin et al. 2006 \\
\hline Bothrops jararaca & $\mathrm{Bj} 2$ & -23.950 & -47.050 & Juquitiba, SP & & Grazziotin et al. 2006 \\
\hline Bothrops jararaca & $\mathrm{Bj} 2$ & -25.767 & -49.733 & Lapa, PR & & Grazziotin et al. 2006 \\
\hline Bothrops jararaca & $\mathrm{Bj} 2$ & -27.567 & -51.667 & Machadinho, RS & & Grazziotin et al. 2006 \\
\hline Bothrops jararaca & $\mathrm{Bj} 2$ & -29.533 & -51.083 & Morro Reuter, RS & & Grazziotin et al. 2006 \\
\hline Bothrops jararaca & $\mathrm{Bj} 2$ & -27.117 & -51.617 & Nova Petrópolis, RS & & Grazziotin et al. 2006 \\
\hline Bothrops jararaca & $\mathrm{Bj} 2$ & -28.783 & -51.600 & Nova Prata, RS & & Grazziotin et al. 2006 \\
\hline Bothrops jararaca & $\mathrm{Bj} 2$ & -25.450 & -49.067 & Piraquara, PR & & Grazziotin et al. 2006 \\
\hline Bothrops jararaca & $\mathrm{Bj} 2$ & -28.167 & -51.800 & Piratuba, SC & & Grazziotin et al. 2006 \\
\hline Bothrops jararaca & $\mathrm{Bj} 2$ & -26.750 & -49.167 & Pomerode, SC & & Grazziotin et al. 2006 \\
\hline Bothrops jararaca & $\mathrm{Bj} 2$ & -30.033 & -51.217 & Porto Alegre, RS & & Grazziotin et al. 2006 \\
\hline Bothrops jararaca & $\mathrm{Bj} 2$ & -23.167 & -49.733 & Ribeirão Claro, PR & & Grazziotin et al. 2006 \\
\hline Bothrops jararaca & $\mathrm{Bj} 2$ & -29.450 & -51.517 & Salvador do Sul, RS & & Grazziotin et al. 2006 \\
\hline Bothrops jararaca & $\mathrm{Bj} 2$ & -26.217 & -49.400 & São Bento do Sul, SC & & Grazziotin et al. 2006 \\
\hline Bothrops jararaca & $\mathrm{Bj} 2$ & -29.433 & -50.567 & São Francisco de Paula, RS & & Grazziotin et al. 2006 \\
\hline Bothrops jararaca & $\mathrm{Bj} 2$ & -25.567 & -49.167 & São José dos Pinhas, RS & & Grazziotin et al. 2006 \\
\hline Bothrops jararaca & $\mathrm{Bj} 2$ & -24.333 & -50.617 & Telêmaco Borba, PR & & Grazziotin et al. 2006 \\
\hline Bothrops jararaca & $\mathrm{Bj} 2$ & -29.583 & -50.067 & Terra de Areia, RS & & Grazziotin et al. 2006 \\
\hline Bothrops jararaca & $\mathrm{Bj} 2$ & -28.817 & -49.850 & Timbó do Sul, SC & & Grazziotin et al. 2006 \\
\hline Bothrops jararaca & $\mathrm{Bj} 2$ & -27.650 & -54.450 & Tucunduva, RS & & Grazziotin et al. 2006 \\
\hline Bothrops jararaca & $\mathrm{Bj} 2$ & -26.233 & -51.067 & União da Vitória, PR & & Grazziotin et al. 2006 \\
\hline Bothrops jararaca & $\mathrm{Bj} 2$ & -28.933 & -51.550 & Veranópolis, RS & & Grazziotin et al. 2006 \\
\hline Bothrops leucurus & B11 & -20.400 & -40.633 & Domingos Martins, ES & & Puorto et al. 2001 \\
\hline Bothrops leucurus & B11 & -18.083 & -39.567 & Mucuri, BA & & Puorto et al. 2001 \\
\hline Bothrops leucurus & B11 & -18.717 & -40.400 & Nova Venécia, ES & & Puorto et al. 2001 \\
\hline Bothrops leucurus & B11 & -16.883 & -39.633 & São Paulinho, BA & & Puorto et al. 2001 \\
\hline Bothrops leucurus & B11 & -12.533 & -38.983 & Teixeira de Freitas, BA & & Puorto et al. 2001 \\
\hline Bothrops leucurus & B12 & -16.433 & -39.083 & Porto Seguro, BA & & Puorto et al. 2001 \\
\hline Bothrops leucurus & $\mathrm{B} 12$ & -12.983 & -38.517 & Salvador, BA & & Puorto et al. 2001 \\
\hline Bothrops leucurus & B12 & -12.533 & -38.983 & Teixeira de Freitas, BA & & Puorto et al. 2001 \\
\hline Bradypus torquatus & Bt1 & -12.500 & -38.050 & Mata de São João, BA & & Lara-Ruiz et al. 2008 \\
\hline Bradypus torquatus & Bt1 & -13.650 & -39.040 & Pratigi, BA & & Lara-Ruiz et al. 2008 \\
\hline Bradypus torquatus & Bt1 & -15.140 & -39.080 & Una, BA & & Lara-Ruiz et al. 2008 \\
\hline Bradypus torquatus & Bt2 & -19.790 & -40.200 & Aracruz, ES & & Lara-Ruiz et al. 2008 \\
\hline
\end{tabular}




\begin{tabular}{|c|c|c|c|c|c|c|}
\hline \multirow[b]{2}{*}{ Group } & \multicolumn{3}{|c|}{ Martitracks Input } & \multirow[b]{2}{*}{ Locality } & \multirow[b]{2}{*}{ Other Information } & \multirow[b]{2}{*}{ Reference } \\
\hline & $\begin{array}{c}\text { Subgroup } \\
\text { Code }\end{array}$ & Lat. & Long. & & & \\
\hline Bradypus torquatus & $\mathrm{Bt} 2$ & -22.550 & -42.280 & Cassimiro de Abreu, RJ & & Lara-Ruiz et al. 2008 \\
\hline Bradypus torquatus & Bt2 & -19.870 & -40.870 & Itarana, ES & & Lara-Ruiz et al. 2008 \\
\hline Bradypus torquatus & Bt2 & -20.030 & -40.700 & Santa Maria, ES & & Lara-Ruiz et al. 2008 \\
\hline Bradypus torquatus & Bt2 & -19.930 & -40.590 & Santa Teresa, ES & & Lara-Ruiz et al. 2008 \\
\hline Bradypus torquatus & $\mathrm{Bt} 2$ & -22.620 & -42.430 & Silva Jardim, RJ & & Lara-Ruiz et al. 2008 \\
\hline Bradypus variegatus & Bv1 & -10.167 & -36.367 & Manimbu, $\mathrm{AL}$ & & Moraes-Barros et al. 2007 \\
\hline Bradypus variegatus & Bv1 & -9.767 & -36.083 & São Miguel dos Campos, AL & & Moraes-Barros et al. 2007 \\
\hline Bradypus variegatus & Bv2 & -14.817 & -39.033 & Ilhéus, BA & & Moraes-Barros et al. 2006 \\
\hline Bradypus variegatus & Bv2 & -14.800 & -39.267 & Itabuna, BA & & Moraes-Barros et al. 2006 \\
\hline Bradypus variegatus & Bv3 & -23.450 & -46.733 & Jaraguá, SP & & Moraes-Barros et al. 2006 \\
\hline Bradypus variegatus & Bv3 & -22.817 & -45.217 & Represa de Guarapiranga, SP & & Moraes-Barros et al. 2006 \\
\hline Bradypus variegatus & $\mathrm{Bv} 3$ & -23.600 & -46.767 & Santos, SP & & Moraes-Barros et al. 2006 \\
\hline Bradypus variegatus & $\mathrm{Bv} 3$ & -23.333 & -45.383 & Serra da Cantareira, SP & & Moraes-Barros et al. 2006 \\
\hline Bradypus variegatus & Bv3 & -23.483 & -46.217 & Serra do Mar, SP & & Moraes-Barros et al. 2006 \\
\hline Bradypus variegatus & Bv3 & -23.467 & -46.617 & Taboão da Serra, SP & & Moraes-Barros et al. 2006 \\
\hline Bradypus variegatus & Bv2 & -17.850 & -41.500 & Teófilo Otoni, MG & & Moraes-Barros et al. 2006 \\
\hline Bradypus variegatus & Bv3 & -22.817 & -45.217 & Guaratinguetá, SP & & Moraes-Barros et al. 2006 \\
\hline Bradypus variegatus & Bv3 & -23.467 & -46.533 & Guarulhos, SP & & Moraes-Barros et al. 2006 \\
\hline Bradypus variegatus & Bv3 & -23.167 & -46.867 & Jundiaí, SP & & Moraes-Barros et al. 2006 \\
\hline Bradypus variegatus & Bv3 & -23.750 & -46.733 & Moji das Cruzes, SP & & Moraes-Barros et al. 2006 \\
\hline Bradypus variegatus & Bv3 & -22.650 & -45.900 & Praia de Boraceia, SP & & Moraes-Barros et al. 2006 \\
\hline Bradypus variegatus & Bv3 & -23.800 & -45.417 & São Sebastião, SP & & Moraes-Barros et al. 2006 \\
\hline Bradypus variegatus & Bv3 & -23.483 & -47.450 & Sorocaba, SP & & Moraes-Barros et al. 2006 \\
\hline Bradypus variegatus & $\mathrm{Bv} 3$ & -23.417 & -45.067 & Ubatuba, SP & & Moraes-Barros et al. 2006 \\
\hline Conopophaga lineata & $\mathrm{Cl1}$ & -19.983 & -44.017 & Barreiro, Belo Horizonte, MG & & Pessoa, 2007 \\
\hline Conopophaga lineata & $\mathrm{Cl1}$ & -15.250 & -39.417 & Serra das Lontras, Arataca, BA & & Pessoa, 2007 \\
\hline Conopophaga lineata & $\mathrm{Cl} 2$ & -20.667 & -42.533 & Araponga, MG & & Pessoa, 2007 \\
\hline Conopophaga lineata & $\mathrm{Cl} 2$ & -22.683 & -44.317 & Bananal, SP & & Pessoa, 2007 \\
\hline Conopophaga lineata & $\mathrm{Cl} 2$ & -22.500 & -44.567 & Itatiaia, RJ & & Pessoa, 2007 \\
\hline Conopophaga lineata & $\mathrm{Cl} 2$ & -19.983 & -43.850 & Nova Lima, MG & & Pessoa, 2007 \\
\hline Conopophaga lineata & $\mathrm{Cl} 3$ & -23.283 & -47.467 & Barreiro Rico, SP & & Pessoa, 2007 \\
\hline Conopophaga lineata & $\mathrm{Cl} 3$ & -23.800 & -48.583 & Buri, SP & & Pessoa, 2007 \\
\hline Conopophaga lineata & $\mathrm{Cl} 3$ & -23.850 & -49.150 & Itabera, SP & & Pessoa, 2007 \\
\hline Conopophaga lineata & $\mathrm{Cl} 3$ & -23.927 & -47.070 & Juquitiba, SP & & Pessoa, 2007 \\
\hline Conopophaga lineata & $\mathrm{Cl} 3$ & -23.717 & -47.400 & Piedade, SP & & Pessoa, 2007 \\
\hline Conopophaga lineata & $\mathrm{Cl} 3$ & -23.783 & -50.050 & Pinhalão, PR & & Pessoa, 2007 \\
\hline Conopophaga lineata & $\mathrm{Cl} 3$ & -27.683 & -49.033 & Rancho Queimado, SC & & Pessoa, 2007 \\
\hline Conopophaga lineata & $\mathrm{Cl} 3$ & -23.533 & -47.133 & São Roque, SP & & Pessoa, 2007 \\
\hline Conopophaga lineata & $\mathrm{Cl} 3$ & -23.850 & -49.800 & Wenceslau Braz, PR & & Pessoa, 2007 \\
\hline Conopophaga lineata & $\mathrm{Cl} 4$ & -31.500 & -52.250 & Arroio do Padre, Pelotas, RS & & Pessoa, 2007 \\
\hline Conopophaga lineata & $\mathrm{Cl} 4$ & -22.500 & -52.333 & Morro do Diabo State Park, SP & & Pessoa, 2007 \\
\hline Conopophaga melanops & $\mathrm{Cm} 1$ & -8.967 & -36.067 & g, Coimbra, Usina Serra Grande, AL & & Pessoa, 2007 \\
\hline
\end{tabular}




\begin{tabular}{|c|c|c|c|c|c|c|}
\hline \multirow[b]{2}{*}{ Group } & \multicolumn{3}{|c|}{ Martitracks Input } & \multirow[b]{2}{*}{ Locality } & \multirow[b]{2}{*}{ Other Information } & \multirow[b]{2}{*}{ Reference } \\
\hline & $\begin{array}{c}\text { Subgroup } \\
\text { Code }\end{array}$ & Lat. & Long. & & & \\
\hline Conopophaga melanops & $\mathrm{Cm} 1$ & -9.600 & -35.933 & Fazenda Horizonte, Pilar, AL & & Pessoa, 2007 \\
\hline Conopophaga melanops & $\mathrm{Cm} 1$ & -9.783 & -36.083 & Fazenda Varrela, São Miguel dos Campos, AL & & Pessoa, 2007 \\
\hline Conopophaga melanops & $\mathrm{Cm} 1$ & -7.517 & -35.317 & Timbauba, $\mathrm{PE}$ & & Pessoa, 2007 \\
\hline Conopophaga melanops & $\mathrm{Cm} 2$ & -23.283 & -47.467 & Fazenda Barreiro Rico, SP & & Pessoa, 2007 \\
\hline Conopophaga melanops & $\mathrm{Cm} 2$ & -22.500 & -44.567 & Itatiaia National Park, RJ & & Pessoa, 2007 \\
\hline Conopophaga melanops & $\mathrm{Cm} 2$ & -23.367 & -44.833 & Picinguaba, SP & & Pessoa, 2007 \\
\hline Conopophaga melanops & $\mathrm{Cm} 2$ & -23.850 & -46.150 & Praias de Boracéia, Bertioga, SP & & Pessoa, 2007 \\
\hline Conopophaga melanops & $\mathrm{Cm} 2$ & -14.850 & -40.850 & Vitória da Conquista, BA & & Pessoa, 2007 \\
\hline Dendrocolaptes platyrostris & Dp1 & -20.650 & -42.533 & Araponga, MG & & Cabanne et al. 2011 \\
\hline Dendrocolaptes platyrostris & Dp1 & -22.633 & -48.217 & Barreiro Rico, SP & & Cabanne et al. 2011 \\
\hline Dendrocolaptes platyrostris & Dp1 & -23.650 & -48.533 & Buri, SP & & Cabanne et al. 2011 \\
\hline Dendrocolaptes platyrostris & Dp1 & -22.417 & -44.600 & Itatiaia, RJ & & Cabanne et al. 2011 \\
\hline Dendrocolaptes platyrostris & Dp1 & -22.500 & -52.300 & Morro do Diabo State Park, SP & & Cabanne et al. 2011 \\
\hline Dendrocolaptes platyrostris & Dp1 & -23.700 & -46.983 & Morro Grande State Park, SP & & Cabanne et al. 2011 \\
\hline Dendrocolaptes platyrostris & Dp1 & -23.767 & -50.050 & Pinhalão, PR & & Cabanne et al. 2011 \\
\hline Dendrocolaptes platyrostris & Dp1 & -20.117 & -42.000 & Simonésia, MG & & Cabanne et al. 2011 \\
\hline Dendrocolaptes platyrostris & Dp2 & -31.517 & -52.383 & Arroio do Padre, Pelotas, RS & & Cabanne et al. 2011 \\
\hline Dendrocolaptes platyrostris & Dp2 & -22.500 & -52.300 & Morro do Diabo State Park, SP & & Cabanne et al. 2011 \\
\hline Dendrocolaptes platyrostris & Dp2 & -24.200 & -50.917 & Ortigueira, $\mathrm{PR}$ & & Cabanne et al. 2011 \\
\hline Dendrocolaptes platyrostris & Dp2 & -27.667 & -49.017 & Rancho Queimado, SC & & Cabanne et al. 2011 \\
\hline Dendrocolaptes platyrostris & Dp2 & -22.083 & -48.783 & Wenceslau Braz, PR & & Cabanne et al. 2011 \\
\hline Eleoscytalopus indigoticus & Ei1 & -22.033 & -42.533 & Duas Barras, RJ & & Mata et al. 2009 \\
\hline Eleoscytalopus indigoticus & Ei1 & -19.983 & -43.850 & Nova Lima, MG & & Mata et al. 2009 \\
\hline Eleoscytalopus indigoticus & Ei1 & -14.367 & -40.167 & Boa Nova, BA & & Mata et al. 2009 \\
\hline Eleoscytalopus indigoticus & Ei2 & -25.426 & -50.003 & Palmeira, PR & & Mata et al. 2009 \\
\hline Eleoscytalopus indigoticus & Ei2 & -25.900 & -48.567 & Guaratuba, PR & & Mata et al. 2009 \\
\hline Eleoscytalopus indigoticus & Ei2 & -25.367 & -49.083 & Quatro Barras, PR & & Mata et al. 2009 \\
\hline Euryoryzomys russatus & Er1 & -21.950 & -42.000 & Desengano State Park, RJ & & Miranda et al. 2007 \\
\hline Euryoryzomys russatus & Er1 & -22.483 & -43.000 & Guapimirim, RJ & & Miranda et al. 2007 \\
\hline Euryoryzomys russatus & Er1 & -19.883 & -41.950 & Monte Verde, ES & & Miranda et al. 2007 \\
\hline Euryoryzomys russatus & Er1 & -13.367 & -39.067 & Valença, BA & & Miranda et al. 2007 \\
\hline Euryoryzomys russatus & Er2 & -27.583 & -48.567 & Florianópolis, SC & & Miranda et al. 2007 \\
\hline Euryoryzomys russatus & Er2 & -23.767 & -45.350 & Ilha Bela, SP & & Miranda et al. 2007 \\
\hline Euryoryzomys russatus & Er2 & -29.633 & -51.000 & Sapiranga, RS & & Miranda et al. 2007 \\
\hline Euryoryzomys russatus & Er2 & -29.267 & -50.300 & Tainhas, RS & & Miranda et al. 2007 \\
\hline Gymnodactylus darwinii & $\mathrm{Gd} 1$ & -14.783 & -39.033 & Almada, BA & & Pellegrino et al. 2005 \\
\hline Gymnodactylus darwinii & Gd1 & -9.650 & -35.733 & Mata do Catolé, Maceió, AL & & Pellegrino et al. 2005 \\
\hline Gymnodactylus darwinii & Gd1 & -12.533 & -38.300 & Mata São João, BA & & Pellegrino et al. 2005 \\
\hline Gymnodactylus darwinii & Gd1 & -7.783 & -35.200 & Natal, RN & & Pellegrino et al. 2005 \\
\hline Gymnodactylus darwinii & $\mathrm{Gd} 1$ & -16.433 & -39.050 & Porto Seguro, BA & & Pellegrino et al. 2005 \\
\hline Gymnodactylus darwinii & Gd1 & -12.567 & -38.000 & Praia do Forte, BA & & Pellegrino et al. 2005 \\
\hline Gymnodactylus darwinii & Gd1 & -15.283 & -39.067 & Uma, BA & & Pellegrino et al. 2005 \\
\hline
\end{tabular}




\begin{tabular}{|c|c|c|c|c|c|c|}
\hline \multirow[b]{2}{*}{ Group } & \multicolumn{3}{|c|}{ Martitracks Input } & \multirow[b]{2}{*}{ Locality } & \multirow[b]{2}{*}{ Other Information } & \multirow[b]{2}{*}{ Reference } \\
\hline & $\begin{array}{c}\text { Subgroup } \\
\text { Code }\end{array}$ & Lat. & Long. & & & \\
\hline Gymnodactylus darwinii & $\mathrm{Gd} 3$ & -23.750 & -45.400 & Barra do Uma, SP & & Pellegrino et al. 2005 \\
\hline Gymnodactylus darwinii & Gd3 & -23.333 & -44.750 & Corcovado, Ubatuba, SP & & Pellegrino et al. 2005 \\
\hline Gymnodactylus darwinii & Gd3 & -23.400 & -44.850 & Ilha Comprida, SP & & Pellegrino et al. 2005 \\
\hline Gvmnodactvlus darwinii & $\mathrm{Gd} 3$ & -23.383 & -44.883 & Ilha da Pesca, Ubatuba, SP & & Pellegrino et al. 2005 \\
\hline Gymnodactylus darwinii & Gd3 & -23.417 & -44.850 & Ilha das Couves, Ubatuba, SP & & Pellegrino et al. 2005 \\
\hline Gymnodactylus darwinii & Gd3 & -23.550 & -45.033 & Ilha das Palmas, Ubatuba, SP & & Pellegrino et al. 2005 \\
\hline Gymnodactylus darwinii & Gd3 & -23.567 & -45.150 & Ilha do Mar Virado, Ubatuba, SP & & Pellegrino et al. 2005 \\
\hline Gymnodactylus darwinii & Gd3 & -23.383 & -44.950 & Ilha do Prumirim, Ubatuba, SP & & Pellegrino et al. 2005 \\
\hline Gymnodactylus darwinii & Gd3 & -23.383 & -44.900 & Ilha dos Porcos Pequena, Ubatuba, SP & & Pellegrino et al. 2005 \\
\hline Gymnodactylus darwinii & Gd3 & -23.433 & -44.900 & Ilha Rapada, Ubatuba, SP & & Pellegrino et al. 2005 \\
\hline Gymnodactylus darwinii & Gd3 & -23.350 & -44.900 & Ilha Redonda, SP & & Pellegrino et al. 2005 \\
\hline Gymnodactylus darwinii & Gd3 & -23.517 & -45.033 & Ilhota das cabras, Ubatuba, SP & & Pellegrino et al. 2005 \\
\hline Gymnodactylus darwinii & Gd3 & -23.550 & -45.150 & Ilhote de Fora, Ubatuba, SP & & Pellegrino et al. 2005 \\
\hline Gymnodactylus darwinii & $\mathrm{Gd} 3$ & -23.567 & -45.083 & Ilhote do Sul, Ubaruba, SP & & Pellegrino et al. 2005 \\
\hline Hyla & $\mathrm{H} 1$ & -20.667 & -42.533 & Araponga, Serra do Brigadeiro, MG & Hyla caramaschii & Napoli, 2005 \\
\hline Hyla & $\mathrm{H} 1$ & -20.400 & -40.633 & Domingos Martins, ES & Hyla caramaschii & Napoli, 2005 \\
\hline Hyla & $\mathrm{H} 1$ & -19.917 & -40.400 & Fundão, ES & Hyla caramaschii & Napoli, 2005 \\
\hline Hyla & $\mathrm{H} 1$ & -19.933 & -40.600 & Santa Teresa, ES & Hyla caramaschii & Napoli, 2005 \\
\hline Hyla & $\mathrm{H} 1$ & -20.117 & -42.017 & Simonésia, MG & Hyla caramaschii & Napoli, 2005 \\
\hline Hyla & $\mathrm{H} 2$ & -24.017 & -48.333 & Capão Bonito, Fazenda Intervales, SP & Hyla luctuosa & Napoli, 2000 \\
\hline Hyla & $\mathrm{H} 2$ & -23.650 & -47.217 & Ibiúna, SP & Hyla luctuosa & Napoli, 2000 \\
\hline Hyla & $\mathrm{H} 2$ & -22.500 & -44.567 & Itatiaia, RJ & Hyla luctuosa & Napoli, 2000 \\
\hline Hyla & $\mathrm{H} 2$ & -23.183 & -46.867 & Jundiaí, Serra do Japi, SP & Hyla luctuosa & Napoli, 2000 \\
\hline Hyla & $\mathrm{H} 2$ & -22.600 & -45.183 & Piquete, SP & Hyla luctuosa & Napoli, 2000 \\
\hline Hyla & $\mathrm{H} 2$ & -24.217 & -48.783 & Ribeirão Branco, SP & Hyla luctuosa & Napoli, 2000 \\
\hline Hyla & $\mathrm{H} 2$ & -23.883 & -47.983 & São Miguel Arcanjo, SP & Hyla luctuosa & Napoli, 2000 \\
\hline Hyla & $\mathrm{H} 2$ & -23.417 & -46.650 & Serra da Cantareira, SP & Hyla luctuosa & Napoli, 2000 \\
\hline Hyla & H3 & -22.549 & -43.684 & Engenheiro Paulo de Fontin, Morro Azul, RJ & Hyla circumdata & Napoli, 2000 \\
\hline Hyla & $\mathrm{H} 3$ & -21.850 & -43.800 & Lima Duarte, Conceição do Ibitipoca, Ibitipoca State Park, MG & Hyla circumdata & Napoli, 2000 \\
\hline Hyla & $\mathrm{H} 3$ & -23.783 & -46.317 & Paranapiacaba, SP & Hyla circumdata & Napoli, 2000 \\
\hline Hyla & $\mathrm{H} 3$ & -23.217 & -44.717 & Parati, RJ & Hyla circumdata & Napoli, 2000 \\
\hline Hyla & $\mathrm{H} 3$ & -22.511 & -43.184 & Petrópolis, RJ & Hyla circumdata & Napoli, 2000 \\
\hline Hyla & $\mathrm{H} 3$ & -23.367 & -44.833 & Picinguaba, SP & Hyla circumdata & Napoli, 2000 \\
\hline Hyla & $\mathrm{H} 3$ & -26.250 & -49.383 & São Bento do Sul, SC & Hyla circumdata & Napoli, 2000 \\
\hline Hyla & $\mathrm{H} 3$ & -22.633 & -44.583 & São José do Barreiro, Serra da Bocaina, SP & Hyla circumdata & Napoli, 2000 \\
\hline Hyla & $\mathrm{H} 3$ & -22.167 & -48.750 & SP, Estação Biológica de Boracéia, SP & Hyla circumdata & Napoli, 2000 \\
\hline Hyla & $\mathrm{H} 3$ & -26.267 & -49.383 & Serra Alta, Rio Vermelho, SC & Hyla circumdata & Napoli, 2000 \\
\hline Hyla & $\mathrm{H} 3$ & -22.433 & -42.983 & Teresópolis, RJ & Hyla circumdata & Napoli, 2000 \\
\hline Hypsiboas bischoffi & $\mathrm{Hb} 1$ & -24.750 & -48.500 & Barra do Turvo, SP & & Marcelino et al. 2009 \\
\hline Hypsiboas bischoffi & $\mathrm{Hb} 1$ & -23.883 & -46.417 & Cubatão, SP & & Marcelino et al. 2009 \\
\hline Hypsiboas bischoffi & $\mathrm{Hb} 1$ & -24.167 & -48.533 & Guapiara, SP & & Marcelino et al. 2009 \\
\hline Hypsiboas bischoffi & $\mathrm{Hb} 1$ & -24.583 & -48.583 & Iporanga, SP & & Marcelino et al. 2009 \\
\hline
\end{tabular}




\begin{tabular}{|c|c|c|c|c|c|c|}
\hline \multirow[b]{2}{*}{ Group } & \multicolumn{3}{|c|}{ Martitracks Input } & \multirow[b]{2}{*}{ Locality } & \multirow[b]{2}{*}{ Other Information } & \multirow[b]{2}{*}{ Reference } \\
\hline & $\begin{array}{c}\text { Subgroup } \\
\text { Code }\end{array}$ & Lat. & Long. & & & \\
\hline Hypsiboas bischoffi & $\mathrm{Hb} 1$ & -24.183 & -46.783 & Itanhaém, SP & & Marcelino et al. 2009 \\
\hline Hypsiboas bischoffi & $\mathrm{Hb} 1$ & -23.717 & -46.833 & Itapecerica da Serra, SP & & Marcelino et al. 2009 \\
\hline Hypsiboas bischoffi & $\mathrm{Hb} 1$ & -23.183 & -46.867 & Jundiaí, SP & & Marcelino et al. 2009 \\
\hline Hypsiboas bischoffi & $\mathrm{Hb} 1$ & -23.317 & -46.583 & Mairiporã, SP & & Marcelino et al. 2009 \\
\hline Hypsiboas bischoffi & $\mathrm{Hb} 1$ & -23.400 & -45.433 & Natividade da Serra, SP & & Marcelino et al. 2009 \\
\hline Hypsiboas bischoffi & $\mathrm{Hb} 1$ & -23.817 & -47.700 & Pilar do Sul, SP & & Marcelino et al. 2009 \\
\hline Hypsiboas bischoffi & $\mathrm{Hb} 1$ & -23.200 & -45.583 & Piraí do Sul, PR & & Marcelino et al. 2009 \\
\hline Hypsiboas bischoffi & $\mathrm{Hb} 1$ & -24.217 & -48.783 & Ribeirão Branco, SP & & Marcelino et al. 2009 \\
\hline Hypsiboas bischoffi & $\mathrm{Hb} 1$ & -23.667 & -46.517 & Santo André, SP & & Marcelino et al. 2009 \\
\hline Hypsiboas bischoffi & $\mathrm{Hb} 1$ & -23.533 & -46.617 & São Paulo, SP & & Marcelino et al. 2009 \\
\hline Hypsiboas bischoffi & $\mathrm{Hb} 1$ & -23.417 & -46.650 & Serra da Cantareira, SP & & Marcelino et al. 2009 \\
\hline Hypsiboas bischoffi & $\mathrm{Hb} 2$ & -27.583 & -48.983 & Angelina, SC & & Marcelino et al. 2009 \\
\hline Hypsiboas bischoffi & $\mathrm{Hb} 2$ & -27.900 & -49.133 & Anitápolis, SC & & Marcelino et al. 2009 \\
\hline Hypsiboas bischoffi & $\mathrm{Hb} 2$ & -27.217 & -49.083 & Botuverá, SC & & Marcelino et al. 2009 \\
\hline Hypsiboas bischoffi & $\mathrm{Hb} 2$ & -27.400 & -51.200 & Campos Novos, SC & & Marcelino et al. 2009 \\
\hline Hypsiboas bischoffi & $\mathrm{Hb} 2$ & -26.433 & -49.233 & Corupá, SC & & Marcelino et al. 2009 \\
\hline Hypsiboas bischoffi & $\mathrm{Hb} 2$ & -29.500 & -50.100 & Itatí, RS & & Marcelino et al. 2009 \\
\hline Hypsiboas bischoffi & $\mathrm{Hb} 2$ & -27.800 & -50.317 & Lages, SC & & Marcelino et al. 2009 \\
\hline Hypsiboas bischoffi & $\mathrm{Hb} 2$ & -26.118 & -49.802 & Mafra, SC & & Marcelino et al. 2009 \\
\hline Hypsiboas bischoffi & $\mathrm{Hb} 2$ & -25.467 & -48.817 & Morretes, PR & & Marcelino et al. 2009 \\
\hline Hypsiboas bischoffi & $\mathrm{Hb} 2$ & -25.433 & -49.067 & Piraguara, PR & & Marcelino et al. 2009 \\
\hline Hypsiboas bischoffi & $\mathrm{Hb} 2$ & -27.683 & -49.033 & Rancho Queimado, SC & & Marcelino et al. 2009 \\
\hline Hypsiboas bischoffi & $\mathrm{Hb} 2$ & -26.933 & -50.450 & Santa Cecília, SC & & Marcelino et al. 2009 \\
\hline Hypsiboas bischoffi & $\mathrm{Hb} 2$ & -26.250 & -49.383 & São Bento do Sul, SC & & Marcelino et al. 2009 \\
\hline Hypsiboas bischoffi & $\mathrm{Hb} 2$ & -29.450 & -50.583 & São Francisco de Paula, RS & & Marcelino et al. 2009 \\
\hline Hypsiboas bischoffi & $\mathrm{Hb} 2$ & -25.517 & -49.217 & São José do Pinhais, PR & & Marcelino et al. 2009 \\
\hline Hypsiboas bischoffi & $\mathrm{Hb} 2$ & -25.927 & -49.179 & Tijucas do Sul, PR & & Marcelino et al. 2009 \\
\hline Hypsiboas bischoffi & $\mathrm{Hb} 2$ & -28.517 & -49.467 & Treviso, SC & & Marcelino et al. 2009 \\
\hline Micoureus & M1 & -13.783 & -39.617 & Fazenda Alto São Roque, Itamari, BA & Micoureus demerarae & Dias et al. 2010 \\
\hline Micoureus & M1 & -14.300 & -39.000 & Fazenda Rio Capitão, Itacaré, BA & Micoureus demerarae & Dias et al. 2010 \\
\hline Micoureus & M1 & -16.433 & -39.083 & Pau Brasil National Park, Porto Seguro, BA & Micoureus demerarae & Dias et al. 2010 \\
\hline Micoureus & M2 & -22.533 & -42.983 & Guapimirim, RJ & Micoureus paraguayanus & Dias et al. 2010 \\
\hline Micoureus & M2 & -19.717 & -42.750 & Rio Doce State Park, Marliéria, MG & Micoureus paraguayanus & Dias et al. 2010 \\
\hline Micoureus & M2 & -20.300 & -43.633 & Rola Moça, Casa Branca, MG & Micoureus paraguayanus & Dias et al. 2010 \\
\hline Micoureus & M2 & -16.950 & -42.483 & Usina Hidrelétrica de Irapé, Berilo, MG & Micoureus paraguayanus & Dias et al. 2010 \\
\hline $\begin{array}{l}\text { Phyllomedusa burmeisteri species } \\
\text { complex }\end{array}$ & $\mathrm{Ph} 1$ & -10.758 & -37.355 & Areia Branca, SE & Phyllomedusa bahiana & Brunes et al. 2010 \\
\hline $\begin{array}{l}\text { Phyllomedusa burmeisteri species } \\
\text { complex }\end{array}$ & $\mathrm{Ph} 1$ & -14.573 & -39.540 & Aurelino Leal, BA & Phyllomedusa bahiana & Brunes et al. 2010 \\
\hline $\begin{array}{c}\text { Phyllomedusa burmeisteri species } \\
\text { complex }\end{array}$ & $\mathrm{Ph} 1$ & -15.416 & -39.509 & Camacan, BA & Phyllomedusa bahiana & Brunes et al. 2010 \\
\hline
\end{tabular}




\begin{tabular}{|c|c|c|c|c|c|c|}
\hline \multirow[b]{2}{*}{ Group } & \multicolumn{3}{|c|}{ Martitracks Input } & \multirow[b]{2}{*}{ Locality } & \multirow[b]{2}{*}{ Other Information } & \multirow[b]{2}{*}{ Reference } \\
\hline & $\begin{array}{c}\text { Subgroup } \\
\text { Code }\end{array}$ & Lat. & Long. & & & \\
\hline $\begin{array}{l}\text { Phyllomedusa burmeisteri species } \\
\text { complex }\end{array}$ & $\mathrm{Ph} 1$ & -16.591 & -42.902 & Grão Mogol, MG & Phyllomedusa bahiana & Brunes et al. 2010 \\
\hline $\begin{array}{l}\text { Phyllomedusa burmeisteri species } \\
\text { complex }\end{array}$ & $\mathrm{Ph} 1$ & -14.782 & -39.064 & Ilhéus, BA & Phyllomedusa bahiana & Brunes et al. 2010 \\
\hline $\begin{array}{l}\text { Phyllomedusa burmeisteri species } \\
\text { complex }\end{array}$ & $\mathrm{Ph} 1$ & -13.441 & -40.431 & Maracas, BA & Phyllomedusa bahiana & Brunes et al. 2010 \\
\hline $\begin{array}{l}\text { Phyllomedusa burmeisteri species } \\
\text { complex }\end{array}$ & $\mathrm{Ph} 1$ & -14.593 & -39.284 & Uruçuca, BA & Phyllomedusa bahiana & Brunes et al. 2010 \\
\hline $\begin{array}{l}\text { Phyllomedusa burmeisteri species } \\
\text { complex }\end{array}$ & $\mathrm{Ph} 2$ & -19.820 & -40.273 & Aracruz, ES & Phyllomedusa burmeisteri & Brunes et al. 2010 \\
\hline $\begin{array}{l}\text { Phyllomedusa burmeisteri species } \\
\text { complex }\end{array}$ & $\mathrm{Ph} 2$ & -23.250 & -46.944 & Jundiaí, SP & Phyllomedusa burmeisteri & Brunes et al. 2010 \\
\hline $\begin{array}{l}\text { Phyllomedusa burmeisteri species } \\
\text { complex }\end{array}$ & $\mathrm{Ph} 2$ & -19.391 & -40.072 & Linhares, ES & Phyllomedusa burmeisteri & Brunes et al. 2010 \\
\hline $\begin{array}{l}\text { Phyllomedusa burmeisteri species } \\
\text { complex }\end{array}$ & $\mathrm{Ph} 2$ & -22.347 & -47.676 & Rio Claro, SP & Phyllomedusa burmeisteri & Brunes et al. 2010 \\
\hline $\begin{array}{l}\text { Phyllomedusa burmeisteri species } \\
\text { complex }\end{array}$ & $\mathrm{Ph} 3$ & -25.429 & -48.712 & Antonina, PR & Phyllomedusa distincta & Brunes et al. 2010 \\
\hline $\begin{array}{l}\text { Phyllomedusa burmeisteri species } \\
\text { complex }\end{array}$ & $\mathrm{Ph} 3$ & -26.722 & -48.766 & Barra Velha, SC & Phyllomedusa distincta & Brunes et al. 2010 \\
\hline $\begin{array}{l}\text { Phyllomedusa burmeisteri species } \\
\text { complex }\end{array}$ & $\mathrm{Ph} 3$ & -25.869 & -48.632 & Guaratuba, PR & Phyllomedusa distincta & Brunes et al. 2010 \\
\hline $\begin{array}{l}\text { Phyllomedusa burmeisteri species } \\
\text { complex }\end{array}$ & $\mathrm{Ph} 3$ & -24.533 & -48.700 & Iporanga, SP & Phyllomedusa distincta & Brunes et al. 2010 \\
\hline $\begin{array}{l}\text { Phyllomedusa burmeisteri species } \\
\text { complex }\end{array}$ & $\mathrm{Ph} 3$ & -24.208 & -50.949 & Ortigueira, PR & Phyllomedusa distincta & Brunes et al. 2010 \\
\hline $\begin{array}{l}\text { Phyllomedusa burmeisteri species } \\
\text { complex }\end{array}$ & $\mathrm{Ph} 3$ & -24.715 & -47.881 & Pariquera-Açu, SP & Phyllomedusa distincta & Brunes et al. 2010 \\
\hline $\begin{array}{l}\text { Phyllomedusa burmeisteri species } \\
\text { complex }\end{array}$ & $\mathrm{Ph} 3$ & -23.813 & -47.716 & Pilar do Sul, SP & Phyllomedusa distincta & Brunes et al. 2010 \\
\hline $\begin{array}{l}\text { Phyllomedusa burmeisteri species } \\
\text { complex }\end{array}$ & $\mathrm{Ph} 3$ & -24.359 & -48.743 & Ribeirão Preto, SP & Phyllomedusa distincta & Brunes et al. 2010 \\
\hline $\begin{array}{l}\text { Phyllomedusa burmeisteri species } \\
\text { complex }\end{array}$ & $\mathrm{Ph} 3$ & -26.250 & -49.379 & São Bento do Sul, SC & Phyllomedusa distincta & Brunes et al. 2010 \\
\hline $\begin{array}{l}\text { Phyllomedusa burmeisteri species } \\
\text { complex }\end{array}$ & $\mathrm{Ph} 3$ & -28.516 & -49.458 & Treviso, SC & Phyllomedusa distincta & Brunes et al. 2010 \\
\hline $\begin{array}{l}\text { Phyllomedusa burmeisteri species } \\
\text { complex }\end{array}$ & $\mathrm{Ph} 4$ & -22.599 & -50.393 & Assis, SP & Phyllomedusa tetraploidea & Brunes et al. 2010 \\
\hline $\begin{array}{l}\text { Phyllomedusa burmeisteri species } \\
\text { complex }\end{array}$ & $\mathrm{Ph} 4$ & -23.798 & -48.593 & Buri, SP & Phyllomedusa tetraploidea & Brunes et al. 2010 \\
\hline $\begin{array}{l}\text { Phyllomedusa burmeisteri species } \\
\text { complex }\end{array}$ & $\mathrm{Ph} 4$ & -26.078 & -51.258 & Cruz Machado, PR & Phyllomedusa tetraploidea & Brunes et al. 2010 \\
\hline
\end{tabular}




\begin{tabular}{|c|c|c|c|c|c|c|}
\hline \multirow[b]{2}{*}{ Group } & \multicolumn{3}{|c|}{ Martitracks Input } & \multirow[b]{2}{*}{ Locality } & \multirow[b]{2}{*}{ Other Information } & \multirow[b]{2}{*}{ Reference } \\
\hline & $\begin{array}{c}\text { Subgroup } \\
\text { Code }\end{array}$ & Lat. & Long. & & & \\
\hline $\begin{array}{l}\text { Phyllomedusa burmeisteri species } \\
\text { complex }\end{array}$ & $\mathrm{Ph} 4$ & -27.420 & -51.772 & Piratuba, SC & Phyllomedusa tetraploidea & Brunes et al. 2010 \\
\hline $\begin{array}{l}\text { Phyllomedusa burmeisteri species } \\
\text { complex }\end{array}$ & $\mathrm{Ph} 4$ & -26.631 & -52.455 & São Domingos, SC & Phyllomedusa tetraploidea & Brunes et al. 2010 \\
\hline $\begin{array}{c}\text { Phyllomedusa burmeisteri species } \\
\text { complex }\end{array}$ & $\mathrm{Ph} 4$ & -23.728 & -50.741 & São Jerónimo da Serra, PR & Phyllomedusa tetraploidea & Brunes et al. 2010 \\
\hline Rhinella crucifer species complex & $\mathrm{R} 1$ & -19.933 & -40.150 & Aracruz, ES & Rhinella crucifer & $\begin{array}{c}\text { Thomé et al. } 2010 \text { (Molecular } \\
\text { analyses) }\end{array}$ \\
\hline Rhinella crucifer species complex & R1 & -6.967 & -35.700 & Areia, PB & Rhinella crucifer & $\begin{array}{c}\text { Thomé et al. } 2010 \text { (Molecular } \\
\text { analyses) }\end{array}$ \\
\hline Rhinella crucifer species complex & R1 & -14.338 & -39.322 & Aurelino Leal, BA & Rhinella crucifer & $\begin{array}{c}\text { Thomé et al. } 2010 \text { (Molecular } \\
\text { analyses) }\end{array}$ \\
\hline Rhinella crucifer species complex & R1 & -15.400 & -39.500 & Camacan, BA & Rhinella crucifer & $\begin{array}{c}\text { Thomé et al. } 2010 \text { (Molecular } \\
\text { analyses) }\end{array}$ \\
\hline Rhinella crucifer species complex & $\mathrm{R} 1$ & -16.433 & -39.083 & Porto Seguro, BA & Rhinella crucifer & $\begin{array}{c}\text { Thomé et al. } 2010 \text { (Molecular } \\
\text { analyses) }\end{array}$ \\
\hline Rhinella crucifer species complex & R1 & -17.350 & -39.217 & Prado, BA & Rhinella crucifer & $\begin{array}{c}\text { Thomé et al. } 2010 \text { (Molecular } \\
\text { analyses) }\end{array}$ \\
\hline Rhinella crucifer species complex & $\mathrm{R} 1$ & -8.050 & -34.900 & Recife, PE & Rhinella crucifer & $\begin{array}{c}\text { Thomé et al. } 2010 \text { (Molecular } \\
\text { analyses) }\end{array}$ \\
\hline Rhinella crucifer species complex & $\mathrm{R} 1$ & -19.136 & -39.887 & Sooretama, ES & Rhinella crucifer & $\begin{array}{c}\text { Thomé et al. } 2010 \text { (Molecular } \\
\text { analyses) }\end{array}$ \\
\hline Rhinella crucifer species complex & $\mathrm{R} 1$ & -14.587 & -39.290 & Uruçuca, BA & Rhinella crucifer & $\begin{array}{c}\text { Thomé et al. } 2010 \text { (Molecular } \\
\text { analyses) }\end{array}$ \\
\hline Rhinella crucifer species complex & R1 & -20.419 & -40.328 & Vila Velha, ES & Rhinella crucifer & $\begin{array}{c}\text { Thomé et al. } 2010 \text { (Molecular } \\
\text { analyses) }\end{array}$ \\
\hline Rhinella crucifer species complex & R1 & -16.567 & -42.900 & Grão Mogol, MG & Rhinella pombali & $\begin{array}{c}\text { Thomé et al. } 2010 \text { (Molecular } \\
\text { analyses) }\end{array}$ \\
\hline Rhinella crucifer species complex & R2 & -26.988 & -49.082 & Blumenau, SC & Rhinella abei & $\begin{array}{c}\text { Thomé et al. } 2010 \text { (Molecular } \\
\text { analyses) }\end{array}$ \\
\hline Rhinella crucifer species complex & $\mathrm{R} 2$ & -25.900 & -48.567 & Guaratuba, PR & Rhinella abei & $\begin{array}{c}\text { Thomé et al. } 2010 \text { (Molecular } \\
\text { analyses) }\end{array}$ \\
\hline Rhinella crucifer species complex & $\mathrm{R} 2$ & -27.090 & -48.622 & Itapema, SC & Rhinella abei & $\begin{array}{c}\text { Thomé et al. } 2010 \text { (Molecular } \\
\text { analyses) }\end{array}$ \\
\hline Rhinella crucifer species complex & $\mathrm{R} 2$ & -28.950 & -49.583 & Itapoá, SC & Rhinella abei & $\begin{array}{c}\text { Thomé et al. } 2010 \text { (Molecular } \\
\text { analyses) }\end{array}$ \\
\hline Rhinella crucifer species complex & $\mathrm{R} 2$ & -26.744 & -49.027 & Massaranduba, SC & Rhinella abei & $\begin{array}{c}\text { Thomé et al. } 2010 \text { (Molecular } \\
\text { analyses) }\end{array}$ \\
\hline Rhinella crucifer species complex & $\mathrm{R} 2$ & -25.467 & -48.817 & Morretes, PR & Rhinella abei & $\begin{array}{c}\text { Thomé et al. } 2010 \text { (Molecular } \\
\text { analyses) }\end{array}$ \\
\hline Rhinella crucifer species complex & $\mathrm{R} 2$ & -24.200 & -50.917 & Ortigueira, PR & Rhinella abei & $\begin{array}{c}\text { Thomé et al. } 2010 \text { (Molecular } \\
\text { analyses) }\end{array}$ \\
\hline
\end{tabular}




\begin{tabular}{|c|c|c|c|c|c|c|}
\hline \multirow[b]{2}{*}{ Group } & \multicolumn{3}{|c|}{ Martitracks Input } & \multirow[b]{2}{*}{ Locality } & \multirow[b]{2}{*}{ Other Information } & \multirow[b]{2}{*}{ Reference } \\
\hline & $\begin{array}{c}\text { Subgroup } \\
\text { Code }\end{array}$ & Lat. & Long. & & & \\
\hline Rhinella crucifer species complex & $\mathrm{R} 2$ & -23.783 & -50.050 & Pinhalão, PR & Rhinella abei & $\begin{array}{c}\text { Thomé et al. } 2010 \text { (Molecular } \\
\text { analyses) }\end{array}$ \\
\hline Rhinella crucifer species complex & $\mathrm{R} 2$ & -25.311 & -49.010 & Quatro Barras, PR & Rhinella abei & $\begin{array}{c}\text { Thomé et al. } 2010 \text { (Molecular } \\
\text { analyses) }\end{array}$ \\
\hline Rhinella crucifer species complex & $\mathrm{R} 2$ & -26.733 & -49.267 & Rio dos Cedros, SC & Rhinella abei & $\begin{array}{c}\text { Thomé et al. } 2010 \text { (Molecular } \\
\text { analyses) }\end{array}$ \\
\hline Rhinella crucifer species complex & $\mathrm{R} 2$ & -23.850 & -49.800 & Wenceslau Braz, PR & Rhinella abei & $\begin{array}{l}\text { Thomé et al. } 2010 \text { (Molecular } \\
\text { analyses) }\end{array}$ \\
\hline Rhinella crucifer species complex & $\mathrm{R} 2$ & -22.250 & -45.233 & Cristina, MG & Rhinella ornata & $\begin{array}{l}\text { Thomé et al. } 2010 \text { (Molecular } \\
\text { analyses) }\end{array}$ \\
\hline Rhinella crucifer species complex & $\mathrm{R} 2$ & -22.495 & -43.001 & Guapimirim, RJ & Rhinella ornata & $\begin{array}{c}\text { Thomé et al. } 2010 \text { (Molecular } \\
\text { analyses) }\end{array}$ \\
\hline Rhinella crucifer species complex & $\mathrm{R} 2$ & -20.533 & -41.667 & Ibitirama, ES & Rhinella ornata & $\begin{array}{c}\text { Thomé et al. } 2010 \text { (Molecular } \\
\text { analyses) }\end{array}$ \\
\hline Rhinella crucifer species complex & $\mathrm{R} 2$ & -22.726 & -43.712 & Itaguaí, RJ & Rhinella ornata & $\begin{array}{c}\text { Thomé et al. } 2010 \text { (Molecular } \\
\text { analyses) }\end{array}$ \\
\hline Rhinella crucifer species complex & $\mathrm{R} 2$ & -24.317 & -47.000 & Peruíbe, SP & Rhinella ornata & $\begin{array}{c}\text { Thomé et al. } 2010 \text { (Molecular } \\
\text { analyses) }\end{array}$ \\
\hline Rhinella crucifer species complex & $\mathrm{R} 2$ & -23.717 & -47.400 & Piedade, SP & Rhinella ornata & $\begin{array}{c}\text { Thomé et al. } 2010 \text { (Molecular } \\
\text { analyses) }\end{array}$ \\
\hline Rhinella crucifer species complex & $\mathrm{R} 2$ & -24.217 & -48.783 & Ribeirão Branco, SP & Rhinella ornata & $\begin{array}{l}\text { Thomé et al. } 2010 \text { (Molecular } \\
\text { analyses) }\end{array}$ \\
\hline Rhinella crucifer species complex & $\mathrm{R} 2$ & -22.833 & -45.667 & Santo Antônio do Pinhal, SP & Rhinella ornata & $\begin{array}{l}\text { Thomé et al. } 2010 \text { (Molecular } \\
\text { analyses) }\end{array}$ \\
\hline Rhinella crucifer species complex & $\mathrm{R} 2$ & -21.630 & -47.629 & Santa Rita do Passa Quatro, SP & Rhinella ornata & $\begin{array}{c}\text { Thomé et al. } 2010 \text { (Molecular } \\
\text { analyses) }\end{array}$ \\
\hline Rhinella crucifer species complex & $\mathrm{R} 2$ & -22.606 & -52.301 & Teodoro Sampaio, SP & Rhinella ornata & $\begin{array}{c}\text { Thomé et al. } 2010 \text { (Molecular } \\
\text { analyses) }\end{array}$ \\
\hline Rhinella crucifer species complex & $\mathrm{R} 2$ & -22.449 & -42.987 & Teresópolis, RJ & Rhinella ornata & $\begin{array}{c}\text { Thomé et al. } 2010 \text { (Molecular } \\
\text { analyses) }\end{array}$ \\
\hline Rhinella crucifer species complex & $\mathrm{R} 2$ & -20.067 & -43.400 & Catas Altas, MG & Rhinella pombali & $\begin{array}{c}\text { Thomé et al. } 2010 \text { (Molecular } \\
\text { analyses) }\end{array}$ \\
\hline Rhinella crucifer species complex & $\mathrm{R} 2$ & -20.533 & -43.700 & Ouro Branco, MG & Rhinella pombali & $\begin{array}{c}\text { Thomé et al. } 2010 \text { (Molecular } \\
\text { analyses) }\end{array}$ \\
\hline Rhinella crucifer species complex & $\mathrm{R} 3$ & -29.178 & -51.463 & Bento Gonçalves, RS & Rhinella henseli & $\begin{array}{l}\text { Thomé et al. } 2010 \text { (Molecular } \\
\text { analyses) }\end{array}$ \\
\hline Rhinella crucifer species complex & R3 & -28.278 & -52.192 & Mato Castelhano, SC & Rhinella henseli & $\begin{array}{c}\text { Thomé et al. } 2010 \text { (Molecular } \\
\text { analyses) }\end{array}$ \\
\hline Scytalopus & Sp1 & -15.250 & -39.417 & Arataca, BA & & Mata et al. 2009 \\
\hline Scytalopus & Sp1 & -14.750 & -40.067 & Iguaí, BA & & Mata et al. 2009 \\
\hline Scytalopus & Sp1 & -14.367 & -40.167 & Boa Nova, BA & & Mata et al. 2009 \\
\hline Scytalopus & $\mathrm{Sp} 2$ & -22.500 & -45.283 & Delfim Moreira, MG & & Mata et al. 2009 \\
\hline
\end{tabular}




\begin{tabular}{|c|c|c|c|c|c|c|}
\hline \multirow[b]{2}{*}{ Group } & \multicolumn{3}{|c|}{ Martitracks Input } & \multirow[b]{2}{*}{ Locality } & \multirow[b]{2}{*}{ Other Information } & \multirow[b]{2}{*}{ Reference } \\
\hline & $\begin{array}{c}\text { Subgroup } \\
\text { Code }\end{array}$ & Lat. & Long. & & & \\
\hline Scytalopus & Sp2 & -20.617 & -42.150 & Divino, $\mathrm{MG}$ & & Mata et al. 2009 \\
\hline Scytalopus & $\mathrm{Sp} 4$ & -25.600 & -49.617 & Balsa Nova, PR & & Mata et al. 2009 \\
\hline Scytalopus & $\mathrm{Sp} 4$ & -24.500 & -50.400 & Tibagi, PR & & Mata et al. 2009 \\
\hline Scytalopus & $\mathrm{Sp} 4$ & -25.426 & -50.003 & Palmeira, PR & & Mata et al. 2009 \\
\hline Scytalopus & Sp4 & -24.467 & -49.033 & Barra do Chapéu, SP & & Mata et al. 2009 \\
\hline Scytalopus & Sp5 & -28.333 & -49.633 & Bom Jardim da Serra, SC & & Mata et al. 2009 \\
\hline Scytalopus & Sp5 & -26.467 & -51.417 & General Carneiro, PR & & Mata et al. 2009 \\
\hline Scytalopus & $\mathrm{Sp} 5$ & -25.300 & -49.083 & Campina Grande do Sul, PR & & Mata et al. 2009 \\
\hline Scytalopus & Sp5 & -25.367 & -49.083 & Quatro Barras, PR & & Mata et al. 2009 \\
\hline Scytalopus & Sp5 & -25.900 & -48.567 & Guaratuba, PR & & Mata et al. 2009 \\
\hline Scytalopus & Sp5 & -26.194 & -49.266 & Campo Alegre, SC & & Mata et al. 2009 \\
\hline Scytalopus & Sp6 & -31.767 & -52.500 & Capão do Leão, RS & & Mata et al. 2009 \\
\hline Scytalopus & Sp6 & -31.767 & -52.333 & Pelotas, Arroio do Padre, RS & & Mata et al. 2009 \\
\hline Scytalopus & Sp6 & -27.350 & -52.783 & Nonoai, RS & & Mata et al. 2009 \\
\hline Scytalopus & Sp6 & -27.250 & -53.867 & Derrubadas, RS & & Mata et al. 2009 \\
\hline Scytalopus & Sp6 & -29.033 & -50.150 & Cambará do Sul, RS & & Mata et al. 2009 \\
\hline Scytalopus & Sp6 & -29.450 & -50.583 & São Francisco de Paula, RS & & Mata et al. 2009 \\
\hline Scytalopus & Sp6 & -29.683 & -50.183 & Maquiné, RS & & Mata et al. 2009 \\
\hline Sclerurus scansor & Ss1 & -7.333 & -40.000 & Chapada do Araripe, Crato, CE & & D'Horta, et al. 2011 \\
\hline Sclerurus scansor & Ss1 & -4.250 & -38.933 & Guaramiranga, Serra de Baturité, CE & & D'Horta, et al. 2011 \\
\hline Sclerurus scansor & Ss1 & -4.500 & -39.617 & Itatira, Serra do Machado, CE & & D'Horta, et al. 2011 \\
\hline Sclerurus scansor & Ss1 & -3.883 & -38.667 & Maranguapé, Serra de Maranguapé, CE & & D'Horta, et al. 2011 \\
\hline Sclerurus scansor & Ss1 & -5.850 & -39.883 & RPPN Serra das Almas, Jatobá Medonho, CE & & D'Horta, et al. 2011 \\
\hline Sclerurus scansor & Ss1 & -4.217 & -38.933 & Serra de Baturité, Pacoti, CE & & D'Horta, et al. 2011 \\
\hline Sclerurus scansor & Ss 1 & -3.850 & -40.933 & Serra de Ibiapaba, Ubajara, CE & & D'Horta, et al. 2011 \\
\hline Sclerurus scansor & Ss1 & -4.300 & -39.000 & Sítio Sinimbu, Mulungu, Serra de Baturité, CE & & D'Horta, et al. 2011 \\
\hline Sclerurus scansor & Ss2 & -20.667 & -42.533 & Araponga, Serra do Brigadeiro State Park, MG & & D'Horta, et al. 2011 \\
\hline Sclerurus scansor & Ss2 & -22.167 & -48.750 & Boracéia, SP & & D'Horta, et al. 2011 \\
\hline Sclerurus scansor & Ss2 & -22.683 & -44.317 & EE Bananal, SP & & D'Horta, et al. 2011 \\
\hline Sclerurus scansor & Ss2 & -16.433 & -41.000 & Jequitinhonha, MG & & D'Horta, et al. 2011 \\
\hline Sclerurus scansor & Ss2 & -23.927 & -47.070 & Juquitibá, SP & & D'Horta, et al. 2011 \\
\hline Sclerurus scansor & Ss2 & -23.700 & -46.550 & São Bernardo do Campo, SP & & D'Horta, et al. 2011 \\
\hline Sclerurus scansor & Ss3 & -23.800 & -48.583 & Buri, SP & & D'Horta, et al. 2011 \\
\hline Sclerurus scansor & Ss3 & -31.767 & -52.333 & Colónia Cerrito, Arroio do Padre, Pelotas, RS & & D'Horta, et al. 2011 \\
\hline Sclerurus scansor & Ss3 & -23.927 & -47.070 & Juquitibá, SP & & D'Horta, et al. 2011 \\
\hline Sclerurus scansor & Ss 3 & -23.717 & -47.400 & Piedade, SP & & D'Horta, et al. 2011 \\
\hline Sclerurus scansor & Ss 3 & -27.683 & -49.033 & Rancho Queimado, SC & & D'Horta, et al. 2011 \\
\hline Sclerurus scansor & Ss 3 & -24.200 & -50.917 & Urtigueira, PR & & D'Horta, et al. 2011 \\
\hline Sclerurus scansor & Ss3 & -20.333 & -40.283 & Vila Velha, ES & & D'Horta, et al. 2011 \\
\hline Sclerurus scansor & Ss3 & -23.850 & -49.800 & Wenceslau Braz, PR & & D'Horta, et al. 2011 \\
\hline Thamnophilus ambiguus & Ta1 & -12.800 & -41.333 & Andaraí, BA & & Lacerda et al. 2007 \\
\hline Thamnophilus ambiguus & Ta1 & -17.117 & -43.817 & Bocaiúva, MG & & Lacerda et al. 2007 \\
\hline
\end{tabular}




\begin{tabular}{|c|c|c|c|c|c|c|}
\hline \multirow[b]{2}{*}{ Group } & \multicolumn{3}{|c|}{ Martitracks Input } & \multirow[b]{2}{*}{ Locality } & \multirow[b]{2}{*}{ Other Information } & \multirow[b]{2}{*}{ Reference } \\
\hline & $\begin{array}{c}\text { Subgroup } \\
\text { Code }\end{array}$ & Lat. & Long. & & & \\
\hline Thamnophilus ambiguus & Ta1 & -16.433 & -41.000 & Jequitinhonha, MG & & Lacerda et al. 2007 \\
\hline Thamnophilus ambiguus & Ta1 & -16.017 & -40.417 & José Gonçalves de Minas, MG & & Lacerda et al. 2007 \\
\hline Thamnophilus ambiguus & Ta1 & -17.083 & -42.667 & Leme do Prado, MG & & Lacerda et al. 2007 \\
\hline Thamnophilus ambiguus & Ta1 & -16.000 & -39.967 & Salto da Divisa, MG & & Lacerda et al. 2007 \\
\hline Thamnophilus ambiguus & $\mathrm{Ta} 2$ & -19.783 & -42.133 & Caratinga, MG & & Lacerda et al. 2007 \\
\hline Thamnophilus ambiguus & $\mathrm{Ta} 2$ & -19.717 & -42.750 & Marliéria, MG & & Lacerda et al. 2007 \\
\hline Thamnophilus ambiguus & $\mathrm{Ta} 2$ & -18.083 & -39.567 & Mucuri, BA & & Lacerda et al. 2007 \\
\hline Thamnophilus ambiguus & $\mathrm{Ta} 2$ & -16.433 & -39.083 & Porto Seguro, BA & & Lacerda et al. 2007 \\
\hline Thoropa miliaris species complex & Th1 & -20.500 & -41.900 & Capraó National Park, MG & Thoropa miliaris & Fitzpatrick et al. 2009 \\
\hline Thoropa miliaris species complex & Th1 & -20.433 & -41.017 & Domingos Martins, ES & Thoropa miliaris & Fitzpatrick et al. 2009 \\
\hline Thoropa miliaris species complex & Th1 & -22.533 & -43.233 & Petrópolis, RJ & Thoropa miliaris & Fitzpatrick et al. 2009 \\
\hline Thoropa miliaris species complex & Th1 & -19.950 & -40.533 & Reserva Santa Lúcia, Santa Tereza, ES & Thoropa miliaris & Fitzpatrick et al. 2009 \\
\hline Thoropa miliaris species complex & Th1 & -21.767 & -42.533 & Vale da Revolta, RJ & Thoropa miliaris & Fitzpatrick et al. 2009 \\
\hline Thoropa miliaris species complex & Th2 & -20.300 & -40.283 & Canto da Praia, Vitória, ES & Thoropa miliaris & Fitzpatrick et al. 2009 \\
\hline Thoropa miliaris species complex & Th2 & -20.433 & -41.017 & Domingos Martins, ES & Thoropa miliaris & Fitzpatrick et al. 2009 \\
\hline Thoropa miliaris species complex & Th2 & -19.950 & -40.533 & Reserva Santa Lúcia, Santa Tereza, ES Brazil & Thoropa miliaris & Fitzpatrick et al. 2009 \\
\hline Thoropa miliaris species complex & Th3 & -23.350 & -44.950 & $\begin{array}{c}\text { BR101 Rodovia Rio Santos, stream km 27, Núcleo Picinguaba, Parque } \\
\text { Estadual da Serra do Mar, SP }\end{array}$ & Thoropa taophora & Fitzpatrick et al. 2009 \\
\hline Thoropa miliaris species complex & Th3 & -23.350 & -44.767 & $\begin{array}{l}\text { BR101 Rodovia Rio Santos, stream km 3, Núcleo Picinguaba, Parque Estadual } \\
\text { da Serra do Mar, SP }\end{array}$ & Thoropa taophora & Fitzpatrick et al. 2009 \\
\hline Thoropa miliaris species complex & Th3 & -23.350 & -44.783 & $\begin{array}{c}\text { BR101 Rodovia Rio Santos, stream km 3,5, Núcleo Picinguaba, Parque } \\
\text { Estadual da Serra do Mar, SP }\end{array}$ & Thoropa taophora & Fitzpatrick et al. 2009 \\
\hline Thoropa miliaris species complex & Th3 & -23.317 & -44.883 & $\begin{array}{c}\text { BR101 Rodovia Rio Santos, wall km 16,9, Núcleo Picinguaba, Parque } \\
\text { Estadual da Serra do Mar, SP }\end{array}$ & Thoropa taophora & Fitzpatrick et al. 2009 \\
\hline Thoropa miliaris species complex & Th3 & -23.350 & -44.933 & $\begin{array}{c}\text { BR101 Rodovia Rio Santos, wall km 19,2, Núcleo Picinguaba, Parque } \\
\text { Estadual da Serra do Mar, SP }\end{array}$ & Thoropa taophora & Fitzpatrick et al. 2009 \\
\hline Thoropa miliaris species complex & Th3 & -23.350 & -44.767 & $\begin{array}{l}\text { BR101 Rodovia Rio Santos, wall km 3, Núcleo Picinguaba, Parque Estadual } \\
\text { da Serra do Mar, SP }\end{array}$ & Thoropa taophora & Fitzpatrick et al. 2009 \\
\hline Thoropa miliaris species complex & Th3 & -23.350 & -44.817 & Headquarters, Núcleo Picinguaba, Parque Estadual Serra do Mar, SP & Thoropa taophora & Fitzpatrick et al. 2009 \\
\hline Thoropa miliaris species complex & Th3 & -23.417 & -44.850 & Ilha das Couves Norte, SP & Thoropa taophora & Fitzpatrick et al. 2009 \\
\hline Thoropa miliaris species complex & Th3 & -23.367 & -44.900 & Ilha dos Porcos Pequena, Ubatuba, SP & Thoropa taophora & Fitzpatrick et al. 2009 \\
\hline Thoropa miliaris species complex & Th3 & -23.350 & -44.900 & Ilha Redonda, SP & Thoropa taophora & Fitzpatrick et al. 2009 \\
\hline Thoropa miliaris species complex & Th3 & -23.350 & -44.867 & Praia Brava da Almada, SP & Thoropa taophora & Fitzpatrick et al. 2009 \\
\hline Thoropa miliaris species complex & Th3 & -23.350 & -44.833 & Vietnam trail, Núcleo Picinguaba, Parque Estadual Serra do Mar, SP & Thoropa taophora & Fitzpatrick et al. 2009 \\
\hline Thoropa miliaris species complex & Th4 & -23.733 & -45.750 & Barra do Una, SP & Thoropa taophora & Fitzpatrick et al. 2009 \\
\hline Thoropa miliaris species complex & Th4 & -23.350 & -44.950 & $\begin{array}{l}\text { BR101 Rodovia Rio Santos, stream km 27, Núcleo Picinguaba, Parque } \\
\text { Estadual da Serra do Mar, SP }\end{array}$ & Thoropa taophora & Fitzpatrick et al. 2009 \\
\hline Thoropa miliaris species complex & Th4 & -23.383 & -44.983 & $\begin{array}{c}\text { BR101 Rodovia Rio Santos, stream km 34,5, Núcleo Picinguaba, Parque } \\
\text { Estadual da Serra do Mar, SP }\end{array}$ & Thoropa taophora & Fitzpatrick et al. 2009 \\
\hline Thoropa miliaris species complex & Th4 & -23.350 & -44.933 & $\begin{array}{c}\text { BR101 Rodovia Rio Santos, wall km 19,2, Núcleo Picinguaba, Parque } \\
\text { Estadual da Serra do Mar, SP }\end{array}$ & Thoropa taophora & Fitzpatrick et al. 2009 \\
\hline Thoropa miliaris species complex & Th4 & -23.367 & -44.950 & Cachoeira Prumirim, SP & Thoropa taophora & Fitzpatrick et al. 2009 \\
\hline
\end{tabular}




\begin{tabular}{|c|c|c|c|c|c|c|}
\hline \multirow[b]{2}{*}{ Group } & \multicolumn{3}{|c|}{ Martitracks Input } & \multirow[b]{2}{*}{ Locality } & \multirow[b]{2}{*}{ Other Information } & \multirow[b]{2}{*}{ Reference } \\
\hline & $\begin{array}{c}\text { Subgroup } \\
\text { Code }\end{array}$ & Lat. & Long. & & & \\
\hline Thoropa miliaris species complex & Th4 & -23.800 & -45.717 & Ilha das Couves Sul, SP & Thoropa taophora & Fitzpatrick et al. 2009 \\
\hline Thoropa miliaris species complex & Th4 & -23.817 & -45.350 & Ilha de São Sebastião, Parque estadual da Ilhabela, SP & Thoropa taophora & Fitzpatrick et al. 2009 \\
\hline Thoropa miliaris species complex & Th4 & -23.833 & -45.517 & Ilha de Toque Toque, SP & Thoropa taophora & Fitzpatrick et al. 2009 \\
\hline Thoropa miliaris species complex & Th4 & -23.800 & -45.667 & Ilha dos Gatos, SP & Thoropa taophora & Fitzpatrick et al. 2009 \\
\hline Thoropa miliaris species complex & Th4 & -23.383 & -44.933 & Illha Prumirim, SP & Thoropa taophora & Fitzpatrick et al. 2009 \\
\hline Thoropa miliaris species complex & Th4 & -23.583 & -45.283 & Ilha Tamanduá, SP & Thoropa taophora & Fitzpatrick et al. 2009 \\
\hline Thoropa miliaris species complex & Th4 & -23.450 & -45.050 & Itaguá, Ubatuba, SP & Thoropa taophora & Fitzpatrick et al. 2009 \\
\hline Thoropa miliaris species complex & Th4 & -23.500 & -45.117 & Praia da Sununga, SP & Thoropa taophora & Fitzpatrick et al. 2009 \\
\hline Thoropa miliaris species complex & Th4 & -23.483 & -45.133 & Praia Domingas Dias, SP & Thoropa taophora & Fitzpatrick et al. 2009 \\
\hline Thoropa miliaris species complex & Th4 & -23.833 & -46.350 & Santos, SP & Thoropa taophora & Fitzpatrick et al. 2009 \\
\hline Thoropa miliaris species complex & Th4 & -23.550 & -45.300 & Trilha Mococa, Núcleo Caragiatatuba, Parque estadual Serra do Mar, SP & Thoropa taophora & Fitzpatrick et al. 2009 \\
\hline Thoropa miliaris species complex & Th4 & -23.683 & -45.662 & Trilha Petrobrás, Núcleo Caraguatatuba, Parque Estadual Serra do Mar, SP & Thoropa taophora & Fitzpatrick et al. 2009 \\
\hline Trinomys & $\operatorname{Tr} 2$ & -19.017 & -43.417 & Mata da Praúna, $5 \mathrm{~km} N$ by rd Conceição do Mato Dentro, MG & $\begin{array}{l}\text { Trinomys iheringi } \\
\text { denigratus }\end{array}$ & Lara \& Patton, 2000 \\
\hline Trinomys & $\operatorname{Tr} 2$ & -22.917 & -42.817 & Restinga de Maricá, Aeronautic Trail, RJ & Trinomys iheringi eliasi & Lara \& Patton, 2000 \\
\hline Trinomys & $\operatorname{Tr} 2$ & -19.833 & -41.833 & Estação Biológica de Caratinga, Caratinga, MG & Trinomys iheringi paratus & Lara \& Patton, 2000 \\
\hline Trinomys & $\operatorname{Tr} 2$ & -19.817 & -40.167 & Grota da Aracruz Florestal, ES & Trinomys iheringi paratus & Lara \& Patton, 2000 \\
\hline Trinomys & $\operatorname{Tr} 2$ & -20.217 & -42.650 & Fazenda Esmeralda, $30 \mathrm{~km} \mathrm{E,} 4 \mathrm{~km} \mathrm{~N}$ (by rd) Rio Casca, MG & Trinomys setosus elegans & Lara \& Patton, 2000 \\
\hline Trinomys & $\operatorname{Tr} 2$ & -13.367 & -39.083 & Fazenda Aldeia, 7km NNW Valença, BA & Trinomys setosus setosus & Lara \& Patton, 2000 \\
\hline Trinomys & $\operatorname{Tr} 2$ & -11.483 & -37.767 & Fazenda Cruzeiro, 13km SSE Cristinápolis, SE & Trinomys setosus setosus & Lara \& Patton, 2000 \\
\hline Trinomys & $\operatorname{Tr} 3$ & -22.511 & -43.184 & Fazenda Inglesa, Petrópolis, RJ & Trinomys dimidiatus & Lara \& Patton, 2000 \\
\hline Trinomys & $\operatorname{Tr} 3$ & -23.000 & -44.300 & Mambucaba, Angra dos Reis, RJ & Trinomys dimidiatus & Lara \& Patton, 2000 \\
\hline Trinomys & $\operatorname{Tr} 3$ & -21.950 & -42.017 & $\begin{array}{c}\text { Mata da Rifa, Desengano State Park, } 1,7 \mathrm{~km} \mathrm{~N}, 5,1 \mathrm{~km} \mathrm{NE} \text { (by rd) Santa Maria } \\
\text { Magdalena, RJ }\end{array}$ & Trinomys dimidiatus & Lara \& Patton, 2000 \\
\hline Trinomys & $\operatorname{Tr} 3$ & -22.267 & -42.533 & Nova Friburgo, RJ & Trinomys dimidiatus & Lara \& Patton, 2000 \\
\hline Trinomys & $\operatorname{Tr} 3$ & -22.367 & -42.750 & Rio-Teresópolis Road, Garrafão, Serra dos Orgãos, RJ & Trinomys dimidiatus & Lara \& Patton, 2000 \\
\hline Trinomys & $\operatorname{Tr} 3$ & -22.200 & -42.733 & Fazenda São José da Serra, Serra do Paquequé, RJ & $\begin{array}{l}\text { Trinomys iheringi } \\
\text { bonafidei }\end{array}$ & Lara \& Patton, 2000 \\
\hline Trinomys & $\operatorname{Tr} 3$ & -20.500 & -41.667 & Caparaó National Park, Rio Pedra Roxa, ES & $\begin{array}{l}\text { Trinomys iheringi } \\
\text { gratiosus }\end{array}$ & Lara \& Patton, 2000 \\
\hline Trinomys & $\operatorname{Tr} 3$ & -19.833 & -40.367 & Estação Biológica de Santa Lúcia, Santa Teresa, ES & $\begin{array}{l}\text { Trinomys iheringi } \\
\text { gratiosus }\end{array}$ & Lara \& Patton, 2000 \\
\hline Trinomys & $\operatorname{Tr} 3$ & -22.233 & -44.200 & Fazenda Bené, Passa Vinte, MG & $\begin{array}{l}\text { Trinomys iheringi } \\
\text { gratiosus }\end{array}$ & Lara \& Patton, 2000 \\
\hline Trinomys & $\operatorname{Tr} 3$ & -22.067 & -44.067 & Santa Rita do Jacutinga, Boqueirão, MG & $\begin{array}{c}\text { Trinomys iheringi } \\
\text { gratiosus }\end{array}$ & Lara \& Patton, 2000 \\
\hline Trinomys & $\operatorname{Tr} 3$ & -23.650 & -45.900 & Estação Biológica de Boracéia, Mogi das Cruzes, SP & Trinomys iheringi iheringi & Lara \& Patton, 2000 \\
\hline Trinomys & $\operatorname{Tr} 3$ & -23.833 & -45.300 & Fazenda da Toca, 2,4 km 0,8km NE (by rd) Ilhabela, Ilha de São Sebastião, SP & Trinomys iheringi iheringi & Lara \& Patton, 2000 \\
\hline Trinomys & $\operatorname{Tr} 3$ & -23.417 & -45.117 & Fazenda do Capricórnio, Ubatuba, SP & Trinomys iheringi iheringi & Lara \& Patton, 2000 \\
\hline Trinomys & $\operatorname{Tr} 3$ & -24.333 & -48.417 & Fazenda Intervales, Carmo Base, 5,5km S Capão Bonito, SP & Trinomys iheringi iheringi & Lara \& Patton, 2000 \\
\hline Trinomys & $\operatorname{Tr} 3$ & -25.133 & -47.967 & Ilha do Cardoso, SP & Trinomys iheringi iheringi & Lara \& Patton, 2000 \\
\hline Trinomys & $\operatorname{Tr} 3$ & -16.433 & -39.083 & Estação Ecológica Pau Brasil, 16km E by rd Porto Seguro, BA & Trinomys $s p$ & Lara \& Patton, 2000 \\
\hline
\end{tabular}




\begin{tabular}{|c|c|c|c|c|c|c|}
\hline \multirow[b]{2}{*}{ Group } & \multicolumn{3}{|c|}{ Martitracks Input } & \multirow[b]{2}{*}{ Locality } & \multirow[b]{2}{*}{ Other Information } & \multirow[b]{2}{*}{ Reference } \\
\hline & $\begin{array}{c}\text { Subgroup } \\
\text { Code }\end{array}$ & Lat. & Long. & & & \\
\hline Xiphorhynchus fuscus & $\mathrm{Xf1}$ & -4.233 & -38.933 & Guaramiranga, Serra de Batrité, CE & Xiphorhynchus fuscus atlanticus & Cabanne et al. 2008 \\
\hline Xiphorhynchus fuscus & Xf1 & -8.983 & -35.867 & Ibateguara, $\mathrm{AL}$ & Xiphorhynchus fuscus atlanticus & Cabanne et al. 2008 \\
\hline Xiphorhynchus fuscus & Xf1 & -4.283 & -38.917 & Mulungú, Serra de Baturité, CE & Xiphorhynchus fuscus atlanticus & Cabanne et al. 2008 \\
\hline Xiphorhynchus fuscus & $\mathrm{Xf} 2$ & -11.900 & -41.200 & Bonito, BA & Xiphorhynchus fuscus brevirostris & Cabanne et al. 2008 \\
\hline Xiphorhynchus fuscus & $\mathrm{Xf2}$ & -16.333 & -41.000 & Jequitinhonha (Mata Escura), MG & Xiphorhynchus fuscus brevirostris & Cabanne et al. 2008 \\
\hline Xiphorhynchus fuscus & $\mathrm{Xf} 2$ & -12.417 & -41.350 & Lençois, BA & Xiphorhynchus fuscus brevirostris & Cabanne et al. 2008 \\
\hline Xiphorhynchus fuscus & $\mathrm{Xf} 2$ & -17.367 & -40.283 & Porto Seguro, BA & Xiphorhynchus fuscus tenuirostris & Cabanne et al. 2008 \\
\hline Xiphorhynchus fuscus & $\mathrm{Xf} 2$ & -16.083 & -40.033 & Salto Divisa, MG & Xiphorhynchus fuscus tenuirostris & Cabanne et al. 2008 \\
\hline Xiphorhynchus fuscus & $\mathrm{Xf} 3$ & -22.833 & -42.550 & Cantagalo, RJ & Xiphorhynchus fuscus fuscus & Cabanne et al. 2008 \\
\hline Xiphorhynchus fuscus & $\mathrm{Xf} 3$ & -20.833 & -42.083 & Caratinga, MG & Xiphorhynchus fuscus fuscus & Cabanne et al. 2008 \\
\hline Xiphorhynchus fuscus & $\mathrm{Xf} 3$ & -22.400 & -44.633 & Itatiaia, RJ & Xiphorhynchus fuscus fuscus & Cabanne et al. 2008 \\
\hline Xiphorhynchus fuscus & $\mathrm{Xf} 3$ & -19.983 & -43.817 & Nova Lima, MG & Xiphorhynchus fuscus fuscus & Cabanne et al. 2008 \\
\hline Xiphorhynchus fuscus & $\mathrm{Xf} 3$ & -19.933 & -40.567 & Santa Teresa, ES & Xiphorhynchus fuscus fuscus & Cabanne et al. 2008 \\
\hline Xiphorhynchus fuscus & $\mathrm{Xf} 3$ & -19.050 & -39.917 & Sooretama, ES & Xiphorhynchus fuscus fuscus & Cabanne et al. 2008 \\
\hline Xiphorhynchus fuscus & $\mathrm{Xf} 4$ & -22.683 & -44.317 & Bananal, SP & Xiphorhynchus fuscus fuscus & Cabanne et al. 2008 \\
\hline Xiphorhynchus fuscus & $\mathrm{Xf} 4$ & -22.633 & -48.217 & Barreiro Rico, SP & Xiphorhynchus fuscus fuscus & Cabanne et al. 2008 \\
\hline Xiphorhynchus fuscus & $\mathrm{Xf4}$ & -22.500 & -52.300 & Morro do Diabo State Park, SP & Xiphorhynchus fuscus fuscus & Cabanne et al. 2008 \\
\hline Xiphorhynchus fuscus & $\mathrm{Xf} 4$ & -23.700 & -46.983 & Morro Grande, SP & Xiphorhynchus fuscus fuscus & Cabanne et al. 2008 \\
\hline Xiphorhynchus fuscus & $\mathrm{Xf} 4$ & -27.683 & -49.033 & Rancho Queimado, SC & Xiphorhynchus fuscus fuscus & Cabanne et al. 2008 \\
\hline Xiphorhynchus fuscus & $\mathrm{Xf4}$ & -23.567 & -47.150 & São Roque, SP & Xiphorhynchus fuscus fuscus & Cabanne et al. 2008 \\
\hline Xiphorhynchus fuscus & Xf4 & -22.850 & -49.783 & Wenceslau Braz, PR & Xiphorhynchus fuscus fuscus & Cabanne et al. 2008 \\
\hline
\end{tabular}

Lat., Latitude; Long., Longitude; CE, Ceará; RN, Rio Grande do Norte; PB, Paraíba; PE, Pernambuco; AL, Alagoas; SE, Sergipe; BA, Bahia; MG, Minas Gerais; ES, Espírito Santo; RJ, Rio de Janeiro; SP, São Paulo; PR, Paraná; SC, Santa Catarina; RS, Rio Grande do Sul. 
CAPÍTULO 3.

Table S1. Sampling locations, biological information and type of data obtained for each sample used. Geographic region (GR) numbers are in agreement with Moraes-Barros et al. (2007). < Samples analyzed mitochondrial DNA (Moraes-Barros et al. 2006, 2007, 2011). Additional institutional information is also given.

\begin{tabular}{|c|c|c|c|c|c|c|c|c|c|c|c|c|c|}
\hline Species & Sample Code & Lat & Long & Locality (GR) & Sex & Institutional Info. & Micros & FGB & HBB & RAG2 & HPRT & PLP1 & MultiLoci \\
\hline \multirow[t]{28}{*}{ B. variegatus } & AC02106 & -10.65 & -68.52 & Xapuri, AC, Brazil & $\mathrm{M}$ & & $\mathrm{x}$ & $\mathrm{x}$ & $\mathrm{x}$ & $\mathrm{x}$ & $\mathrm{x}$ & $\mathrm{x}$ & $\mathrm{x}$ \\
\hline & AC02107 & -10.65 & -68.52 & Xapuri, AC, Brazil & M & & $\mathrm{x}$ & $\mathrm{x}$ & $\mathrm{x}$ & & $\mathrm{x}$ & $\mathrm{x}$ & $\mathrm{x}$ \\
\hline & AC02108 & -11.00 & -68.72 & Brasileia, AC, Brazil & & & $\mathrm{x}$ & $\mathrm{x}$ & & & $\mathrm{x}$ & $\mathrm{x}$ & $\mathrm{x}$ \\
\hline & AC02111 & -9.97 & -67.80 & Rio Branco, AC, Brazil & M & & $\mathrm{x}$ & $\mathrm{x}$ & & $\mathrm{x}$ & $\mathrm{x}$ & $\mathrm{x}$ & $\mathrm{x}$ \\
\hline & $02046<$ & -4.47 & -74.17 & Aruaguna Village, Cenepa River, Peru & M & MVZB155186 & $\mathrm{x}$ & $\mathrm{x}$ & $\mathrm{x}$ & & $\mathrm{x}$ & $\mathrm{x}$ & $\mathrm{x}$ \\
\hline & PA02114 & -1.45 & -48.48 & Belém, PA, Brazil (5) & & LNN-UFPA & $\mathrm{x}$ & $\mathrm{x}$ & & $\mathrm{x}$ & $\mathrm{x}$ & $\mathrm{x}$ & $\mathrm{x}$ \\
\hline & PA02115 & -1.45 & -48.48 & Belém, PA, Brazil (5) & & LNN-UFPA & $\mathrm{x}$ & $\mathrm{x}$ & $\mathrm{x}$ & $\mathrm{x}$ & $\mathrm{x}$ & $\mathrm{x}$ & $\mathrm{x}$ \\
\hline & PA02116 & -1.45 & -48.48 & Belém, PA, Brazil (5) & $(\mathrm{F})$ & LNN-UFPA & $\mathrm{x}$ & $\mathrm{x}$ & & $\mathrm{x}$ & $\mathrm{x}$ & $\mathrm{x}$ & $\mathrm{x}$ \\
\hline & PA02117 & -1.45 & -48.48 & Belém, PA, Brazil (5) & M & LNN-UFPA & $\mathrm{x}$ & $\mathrm{x}$ & $\mathrm{x}$ & $\mathrm{x}$ & $\mathrm{x}$ & $\mathrm{x}$ & $\mathrm{x}$ \\
\hline & PA02118 & -1.45 & -48.48 & Belém, PA, Brazil (5) & M & LNN-UFPA & $\mathrm{x}$ & $\mathrm{x}$ & $\mathrm{x}$ & $\mathrm{x}$ & $\mathrm{x}$ & $\mathrm{x}$ & $\mathrm{x}$ \\
\hline & PA02119 & -1.45 & -48.48 & Belém, PA, Brazil (5) & M & LNN-UFPA & $\mathrm{x}$ & $\mathrm{x}$ & $\mathrm{x}$ & $\mathrm{x}$ & $\mathrm{x}$ & & $\mathrm{x}$ \\
\hline & 02162CE & & & CE, Brazil & M & & $\mathrm{x}$ & & & & & & \\
\hline & CE02149 & -3.67 & -40.33 & Sobral, CE, Brazil & $\mathrm{F}$ & CETAS-CE/UFC & $\mathrm{x}$ & $\mathrm{x}$ & $\mathrm{x}$ & $\mathrm{x}$ & $\mathrm{x}$ & $\mathrm{x}$ & $\mathrm{x}$ \\
\hline & РB02140 & -6.83 & -35.12 & PB, Brazil & $\mathrm{F}$ & UFPE1712-DAM168 & & & $\mathrm{x}$ & $\mathrm{x}$ & $\mathrm{x}$ & $\mathrm{x}$ & \\
\hline & 02147PB & & & PB, Brazil & $\mathrm{F}$ & CETAS-PB/UFPB & $\mathrm{x}$ & $\mathrm{x}$ & & $\mathrm{x}$ & $\mathrm{x}$ & $\mathrm{x}$ & $\mathrm{x}$ \\
\hline & РB02148 & -7.13 & -34.86 & Mata do Buraquinho, João Pessoa, PB, Brazil & & CETAS-PB/UFPB & $\mathrm{x}$ & $\mathrm{x}$ & & & & $\mathrm{x}$ & $\mathrm{x}$ \\
\hline & PE02120 & -7.83 & -35.12 & Aldeia, PE, Brazil & (F) & UFPE & $\mathrm{x}$ & $\mathrm{x}$ & $\mathrm{x}$ & $\mathrm{x}$ & $\mathrm{x}$ & $\mathrm{x}$ & $\mathrm{x}$ \\
\hline & 02135PE & & & PE, Brazil & M & CETAS-PE & $\mathrm{x}$ & & & & & & \\
\hline & PE02136 & -8.05 & -34.90 & Recife, near BR 232, PE, Brazil & $\mathrm{F}$ & CETAS-PE308 & $\mathrm{x}$ & & $\mathrm{x}$ & $\mathrm{x}$ & $\mathrm{x}$ & $\mathrm{x}$ & $\mathrm{x}$ \\
\hline & PE02137 & -8.05 & -34.90 & Parque Estadual Dois Irmãos, PE, Brazil & M & CETAS-PE369 & $\mathrm{x}$ & $\mathrm{x}$ & $\mathrm{x}$ & $\mathrm{x}$ & $\mathrm{x}$ & $\mathrm{x}$ & $\mathrm{x}$ \\
\hline & 02138PE & & & PE, Brazil & M & CETAS-PE & $\mathrm{x}$ & $\mathrm{x}$ & $\mathrm{x}$ & $\mathrm{x}$ & $\mathrm{x}$ & $\mathrm{x}$ & $\mathrm{x}$ \\
\hline & PE02139 & -7.95 & -34.88 & Estação Ecológica de Caetés, Paulista, PE, Brazil & $\mathrm{F}$ & UFPE1846-DAM185 & $\mathrm{x}$ & & & & $\mathrm{x}$ & $\mathrm{x}$ & $\mathrm{x}$ \\
\hline & PE02141 & -7.83 & -34.90 & Cruz de Rebouças, Igarassu, PE, Brazil & M & UFPE1843-DAM180 & $\mathrm{x}$ & & $\mathrm{x}$ & & $\mathrm{x}$ & & $\mathrm{x}$ \\
\hline & 02142PE & & & PE, Brazil & $\mathrm{F}$ & UFPE2514-DAM271 & $\mathrm{x}$ & & & & & $\mathrm{x}$ & \\
\hline & 02143PE & & & PE, Brazil & $\mathrm{F}$ & UFPE2513-DAM269 & $\mathrm{x}$ & $\mathrm{x}$ & $\mathrm{x}$ & & $\mathrm{x}$ & $\mathrm{x}$ & $\mathrm{x}$ \\
\hline & 02144PE & & & PE, Brazil & $\mathrm{F}$ & UFPE2515-DAM273 & $\mathrm{x}$ & & & & & & \\
\hline & 02145PE & & & PE, Brazil & & UFPE-DAM166 & $\mathrm{x}$ & $\mathrm{x}$ & & & $\mathrm{x}$ & & $\mathrm{x}$ \\
\hline & 02146PE & & & PE, Brazil & & UFPE-DAM210 & $\mathrm{x}$ & $\mathrm{x}$ & & & $\mathrm{x}$ & & $\mathrm{x}$ \\
\hline
\end{tabular}




\begin{tabular}{|c|c|c|c|c|c|c|c|c|c|c|c|c|c|}
\hline Species & Sample Code & Lat & Long & Locality (GR) & Sex & Institutional Info. & Micros & FGB & HBB & RAG2 & HPRT & PLP1 & MultiLoci \\
\hline & PE02159 & -7.78 & -35.01 & Usina São José, Mata do Macaco, PE, Brazil & $\bar{F}$ & Retiro Ecológico & $\bar{x}$ & & & & & & \\
\hline & 02131AL & & & AL, Brazil (3) & & MHN UFAL & $\mathrm{x}$ & $\mathrm{x}$ & $\mathrm{x}$ & $\mathrm{x}$ & & $\mathrm{x}$ & $\mathrm{x}$ \\
\hline & 02132AL & & & AL, Brazil (3) & & MHN UFAL & $\mathrm{x}$ & $\mathrm{x}$ & $\mathrm{x}$ & & $\mathrm{x}$ & $\mathrm{x}$ & $\mathrm{x}$ \\
\hline & AL02133 & -9.67 & -35.72 & Bairro Clima Bom, Maceió, AL, Brazil (3) & $\mathrm{F}$ & CETAS-AL565/178 & $\mathrm{x}$ & & & & & & \\
\hline & AL02151 & -9.67 & -35.72 & Bairro Farol, Maceió, AL, Brazil (3) & $\mathrm{F}$ & CETAS-AL657/192 & $\mathrm{x}$ & $\mathrm{x}$ & $\mathrm{x}$ & & & & $\mathrm{x}$ \\
\hline & AL02152 & -9.67 & -35.72 & Bairro Rio Largo, Maceió, AL, Brazi (3)l & M & CETAS-AL666/194 & $\mathrm{x}$ & & & & & $\mathrm{x}$ & \\
\hline & AL02153 & -9.67 & -35.72 & Maceió, AL, Brazil (3) & $\mathrm{F}$ & CETAS-AL682/198 & $\mathrm{x}$ & $\mathrm{x}$ & & $\mathrm{x}$ & $\mathrm{x}$ & $\mathrm{x}$ & $\mathrm{x}$ \\
\hline & AL02154 & -9.67 & -35.72 & Bairro Bebedouro, Maceió, AL, Brazil (3) & $\mathrm{F}$ & CETAS-AL665/193 & $\mathrm{x}$ & & & & & & \\
\hline & AL02156 & -9.67 & -35.72 & Jardim Petrópolis, Maceió, AL, Brazil (3) & & CETAS-AL & $\mathrm{x}$ & & & & & & \\
\hline & BA02002< & -12.53 & -38.98 & Teixeira de Freitas, BA, Brazil (2) & $\mathrm{F}$ & CEPLAC & $\mathrm{x}$ & $\mathrm{x}$ & $\mathrm{x}$ & & $\mathrm{x}$ & $\mathrm{x}$ & $\mathrm{x}$ \\
\hline & BA02003< & -14.82 & -39.03 & Eunapolis, BA, Brazil (2) & $\mathrm{F}$ & CEPLAC & $\mathrm{x}$ & $\mathrm{x}$ & $\mathrm{x}$ & $\mathrm{x}$ & $\mathrm{x}$ & $\mathrm{x}$ & $\mathrm{x}$ \\
\hline & BA02078< & -14.82 & -39.03 & Ilheus, BA, Brazil (2) & $\mathrm{F}$ & CEPLAC & $\mathrm{x}$ & $\mathrm{x}$ & $\mathrm{x}$ & $\mathrm{x}$ & $\mathrm{x}$ & $\mathrm{x}$ & $\mathrm{x}$ \\
\hline & MG02083< & -17.85 & -41.50 & Teofilo Otoni, MG, Brazil (2) & $\mathrm{F}$ & & $\mathrm{x}$ & $\mathrm{x}$ & $\mathrm{x}$ & & $\mathrm{x}$ & $\mathrm{x}$ & $\mathrm{x}$ \\
\hline & MG02087< & -17.85 & -41.50 & Teofilo Otoni, MG, Brazil (2) & M & & $\mathrm{x}$ & $\mathrm{x}$ & $\mathrm{x}$ & $\mathrm{x}$ & $\mathrm{x}$ & $\mathrm{x}$ & $\mathrm{x}$ \\
\hline & MG02091< & -17.85 & -41.50 & Teofilo Otoni, MG, Brazil (2) & M & & $\mathrm{x}$ & $\mathrm{x}$ & & $\mathrm{x}$ & $\mathrm{x}$ & $\mathrm{x}$ & $\mathrm{x}$ \\
\hline & MG02096< & -17.85 & -41.50 & Teofilo Otoni, MG, Brazil (2) & $\mathrm{M}$ & & $\mathrm{x}$ & $\mathrm{x}$ & $\mathrm{x}$ & $\mathrm{x}$ & $\mathrm{x}$ & $\mathrm{x}$ & $\mathrm{x}$ \\
\hline & MG02098< & -17.85 & -41.50 & Teofilo Otoni, MG, Brazil (2) & M & & $\mathrm{x}$ & $\mathrm{x}$ & $\mathrm{x}$ & $\mathrm{x}$ & $\mathrm{x}$ & $\mathrm{x}$ & $\mathrm{x}$ \\
\hline & SP1735 & -23.93 & -46.32 & Santos, SP, Brazil (1) & $\mathrm{M}$ & Instituto Maracajá & & & & & & $\mathrm{x}$ & \\
\hline & SP2360 & -23.95 & -46.35 & Morro Itararé, SP, Brazil (1) & M & Instituto Maracajá & & & & & & $\mathrm{x}$ & \\
\hline & 3192SP & & & SP, Brazil (1) & & Instituto Maracajá & $\mathrm{x}$ & & & & & & \\
\hline & SP4235 & -23.77 & -45.35 & Ilhabela, SP, Brazil (1) & $\mathrm{F}$ & Instituto Maracajá & $\mathrm{x}$ & & & $\mathrm{x}$ & $\mathrm{x}$ & $\mathrm{x}$ & $\mathrm{x}$ \\
\hline & 4290SP & & & SP, Brazil (1) & & Instituto Maracajá & $\mathrm{x}$ & & & & $\mathrm{x}$ & & \\
\hline & SP4380 & -24.37 & -47.02 & Peruibe, SP, Brazil (1) & $\mathrm{F}$ & Instituto Maracajá & $\mathrm{x}$ & & & & & & \\
\hline & SP4882 & -24.03 & -46.53 & Jardim Melvi, SP, Brazil (1) & $\mathrm{F}$ & Instituto Maracajá & $\mathrm{x}$ & & & & & & \\
\hline & SP5911 & -23.95 & -46.35 & Parque Ecológico Voturua, SP, Brazil (1) & $\mathrm{F}$ & Instituto Maracajá & $\mathrm{x}$ & & & & & $\mathrm{x}$ & \\
\hline & SP7896 & -23.33 & -45.38 & PESM Itutinga Pilões, SP, Brazil (1) & M & Instituto Maracajá & $\mathrm{x}$ & & & & & & \\
\hline & SP8815 & -24.08 & -46.62 & Poço das Antas, SP, Brazil (1) & M & Instituto Maracajá & $\mathrm{x}$ & & & & & & \\
\hline & SP_DPV02006< & -23.53 & -46.62 & Santana, São Paulo, SP, Brazil (1) & $\mathrm{F}$ & DEPAVE-SP10947 & $\mathrm{x}$ & $\mathrm{x}$ & $\mathrm{x}$ & & $\mathrm{x}$ & $\mathrm{x}$ & $\mathrm{x}$ \\
\hline & SP_DPV02008< & -23.33 & -45.38 & Ubatuba, SP, Brazil (1) & & DEPAVE-SP 11365 & $\mathrm{x}$ & & & & & & \\
\hline & SP_DPV02009< & -23.48 & -46.22 & Mogi-Dutra highway, SP, Brazil (1) & M & DEPAVE-SP 12422 & & & & & $\mathrm{x}$ & & \\
\hline & SP_DPV02012 & -23.52 & -46.63 & Parque da Luz, São Paulo, SP, Brazil (1) & $\mathrm{M}$ & DEPAVE-SP 13658 & $\mathrm{x}$ & $\mathrm{x}$ & $\mathrm{x}$ & & $\mathrm{x}$ & $\mathrm{x}$ & $\mathrm{x}$ \\
\hline & SP_DPV02013 & -23.60 & -46.75 & Régis Bittencourt highway, km 224, SP, Brazil (1) & $\mathrm{F}$ & DEPAVE-SP 13669 & $\mathrm{x}$ & $\mathrm{x}$ & $\mathrm{x}$ & & $\mathrm{x}$ & $\mathrm{x}$ & $\mathrm{x}$ \\
\hline
\end{tabular}




\begin{tabular}{|c|c|c|c|c|c|c|c|c|c|c|c|c|c|}
\hline Species & Sample Code & Lat & Long & Locality (GR) & Sex & Institutional Info. & Micros & FGB & HBB & RAG2 & HPRT & PLP1 & MultiLoci \\
\hline & DPV02014SP & & & SP, Brazil (1) & M & DEPAVE-SP 13795 & $\mathrm{x}$ & $\mathrm{x}$ & $\mathrm{x}$ & $\mathrm{x}$ & $\mathrm{x}$ & $\mathrm{x}$ & $\mathrm{x}$ \\
\hline & SP_DPV02051< & -23.18 & -46.87 & Jundiai, SP, Brazil (1) & & DEPAVE-SP 17720 & $\mathrm{x}$ & $\mathrm{x}$ & $\mathrm{x}$ & & $\mathrm{x}$ & $\mathrm{x}$ & $\mathrm{x}$ \\
\hline & SP_DPV30525 & -23.27 & -46.75 & Jardim Alegria, São Paulo, SP, Brazil (1) & & DEPAVE-SP & $\mathrm{x}$ & & & & & & \\
\hline & SP_DPV31532 & -23.72 & -46.83 & Itapecirica da Serra, SP, Brazil (1) & M & DEPAVE-SP & $\mathrm{x}$ & $\mathrm{x}$ & $\mathrm{x}$ & & & $\mathrm{x}$ & $\mathrm{x}$ \\
\hline & DPV31598SP & & & SP, Brazil (1) & & DEPAVE-SP & $\mathrm{x}$ & $\mathrm{x}$ & & & $\mathrm{x}$ & & $\mathrm{x}$ \\
\hline & SP_DPV33852 & -23.85 & -46.73 & Parelheiros, SP, Brazil (1) & $\mathrm{F}$ & DEPAVE-SP & & $\mathrm{x}$ & & & & & \\
\hline & SP_DPV33875 & -23.32 & -46.58 & Mairipora, SP, Brazil (1) & & DEPAVE-SP & $\mathrm{x}$ & $\mathrm{x}$ & & & & $\mathrm{x}$ & $\mathrm{x}$ \\
\hline & SP_DPV37014 & -23.70 & -46.55 & Imigrantes highway, KM 18, SP, Brazil (1) & M & DEPAVE-SP & $\mathrm{x}$ & $\mathrm{x}$ & $\mathrm{x}$ & $\mathrm{x}$ & & $\mathrm{x}$ & $\mathrm{x}$ \\
\hline & SP_DPV38094 & -24.28 & -47.45 & Regis-Bittencourt highway, KM 373, SP, Brazil (1) & M & DEPAVE-SP & $\mathrm{x}$ & $\mathrm{x}$ & $\mathrm{x}$ & $\mathrm{x}$ & $\mathrm{x}$ & $\mathrm{x}$ & $\mathrm{x}$ \\
\hline & SP_DPV38292 & -23.58 & -46.70 & Parque Alfredo Volpi, São Paulo, SP, Brazil (1) & M & DEPAVE-SP & $\mathrm{x}$ & $\mathrm{x}$ & $\mathrm{x}$ & & & $\mathrm{x}$ & $\mathrm{x}$ \\
\hline & SP_DPV39762 & -23.45 & -46.77 & Parque do Jaraguá, SP, Brazil (1) & M & DEPAVE-SP & $\mathrm{x}$ & $\mathrm{x}$ & & & & $\mathrm{x}$ & $\mathrm{x}$ \\
\hline & SP_DPV40168 & -23.52 & -46.63 & Parque da Luz, São Paulo, SP, Brazil (1) & M & DEPAVE-SP & $\mathrm{x}$ & $\mathrm{x}$ & & & $\mathrm{x}$ & $\mathrm{x}$ & $\mathrm{x}$ \\
\hline & SP_DPV40746 & -23.53 & -46.62 & Jardim Casa Grande, São Paulo, SP, Brazil (1) & & DEPAVE-SP & $\mathrm{x}$ & & $\mathrm{x}$ & $\mathrm{x}$ & & $\mathrm{x}$ & $\mathrm{x}$ \\
\hline & SP_DPV42114 & -23.42 & -46.75 & Perus, SP, Brazil (1) & & DEPAVE-SP & $\mathrm{x}$ & $\mathrm{x}$ & $\mathrm{x}$ & $\mathrm{x}$ & $\mathrm{x}$ & $\mathrm{x}$ & $\mathrm{x}$ \\
\hline & SP_DPV42838 & -23.63 & -47.35 & Pirituba, SP, Brazil (1) & & DEPAVE-SP & $\mathrm{x}$ & & & & & & \\
\hline & SP_DPV43029 & -23.40 & -46.33 & Aruja, SP, Brazil (1) & $\mathrm{F}$ & DEPAVE-SP & $\mathrm{x}$ & $\mathrm{x}$ & $\mathrm{x}$ & $\mathrm{x}$ & $\mathrm{x}$ & $\mathrm{x}$ & $\mathrm{x}$ \\
\hline & SP_DPV43030 & -23.80 & -46.63 & Peninsula do Bororé, SP, Brazil (1) & $\mathrm{F}$ & DEPAVE-SP & $\mathrm{x}$ & $\mathrm{x}$ & $\mathrm{x}$ & & & $\mathrm{x}$ & $\mathrm{x}$ \\
\hline & SP02050< & -23.42 & -46.65 & Serra da Cantareira, SP, Brazil (1) & M & Instituto Pau Brasil & $\mathrm{x}$ & $\mathrm{x}$ & & & $\mathrm{x}$ & $\mathrm{x}$ & $\mathrm{x}$ \\
\hline & SP02052< & -23.48 & -47.45 & Sorocaba, SP, Brazil (1) & & Zoo Sorocaba & $\mathrm{x}$ & $\mathrm{x}$ & $\mathrm{x}$ & $\mathrm{x}$ & & $\mathrm{x}$ & $\mathrm{x}$ \\
\hline & 02075SP $<$ & & & SP, Brazil (1) & M & CEPLAC & $\mathrm{x}$ & $\mathrm{x}$ & $\mathrm{x}$ & $\mathrm{x}$ & & $\mathrm{x}$ & $\mathrm{x}$ \\
\hline & & & & & & Total & 75 & 53 & 39 & 32 & 47 & 56 & 56 \\
\hline \multirow[t]{11}{*}{ B. pygmaeus } & PNM11 & 8.63 & -82.48 & Isla Escudo de Veráguas, Panama & & & $\mathrm{x}$ & $\mathrm{x}$ & $\mathrm{x}$ & & & $\mathrm{x}$ & \\
\hline & PNM12 & 8.63 & -82.48 & Isla Escudo de Veráguas, Panama & & & $\mathrm{x}$ & $\mathrm{x}$ & & & & & \\
\hline & PNM13 & 8.63 & -82.48 & Isla Escudo de Veráguas, Panama & & & & $\mathrm{x}$ & $\mathrm{x}$ & $\mathrm{x}$ & $\mathrm{x}$ & $\mathrm{x}$ & \\
\hline & PNM14 & 8.63 & -82.48 & Isla Escudo de Veráguas, Panama & & & & $\mathrm{x}$ & $\mathrm{x}$ & $\mathrm{x}$ & $\mathrm{x}$ & $\mathrm{x}$ & \\
\hline & PNM15 & 8.63 & -82.48 & Isla Escudo de Veráguas, Panama & & & $\mathrm{x}$ & $\mathrm{x}$ & $\mathrm{x}$ & $\mathrm{x}$ & $\mathrm{x}$ & $\mathrm{x}$ & \\
\hline & PNM16 & 8.63 & -82.48 & Isla Escudo de Veráguas, Panama & & & $\mathrm{x}$ & $\mathrm{x}$ & $\mathrm{x}$ & $\mathrm{x}$ & $\mathrm{x}$ & $\mathrm{x}$ & \\
\hline & PNM17 & 8.63 & -82.48 & Isla Escudo de Veráguas, Panama & & & $\mathrm{x}$ & $\mathrm{x}$ & $\mathrm{x}$ & $\mathrm{x}$ & $\mathrm{x}$ & $\mathrm{x}$ & \\
\hline & PNM18 & 8.63 & -82.48 & Isla Escudo de Veráguas, Panama & & & $\mathrm{x}$ & $\mathrm{x}$ & $\mathrm{x}$ & $\mathrm{x}$ & & $\mathrm{x}$ & \\
\hline & PNM19 & 8.63 & -82.48 & Isla Escudo de Veráguas, Panama & & & & $\mathrm{x}$ & $\mathrm{x}$ & $\mathrm{x}$ & $\mathrm{x}$ & $\mathrm{x}$ & \\
\hline & PNM20 & 8.63 & -82.48 & Isla Escudo de Veráguas, Panama & & & $\mathrm{x}$ & $\mathrm{x}$ & $\mathrm{x}$ & $\mathrm{x}$ & $\mathrm{x}$ & $\mathrm{x}$ & \\
\hline & & & & & & Total & 7 & 10 & 9 & 8 & 7 & 9 & \\
\hline
\end{tabular}




\begin{tabular}{|c|c|c|c|c|c|c|c|c|c|c|c|c|c|}
\hline Species & Sample Code & Lat & Long & Locality (GR) & Sex & Institutional Info. & Micros & FGB & HBB & RAG2 & HPRT & PLP1 & MultiLoci \\
\hline \multirow[t]{17}{*}{ B. torquatus } & BA449/11 & & & BA, Brazil & $\mathrm{F}$ & CETAS-BA & & $\mathrm{x}$ & $\mathrm{x}$ & $\mathrm{x}$ & $\mathrm{x}$ & $\mathrm{x}$ & \\
\hline & BA01002 & & & BA, Brazil & M & CEPLAC & & & & & & $\mathrm{x}$ & \\
\hline & BA01003 & -14.82 & -39.03 & Ilheus, BA, Brazil & $\mathrm{M}$ & CEPLAC & & & $\mathrm{x}$ & & & $\mathrm{x}$ & \\
\hline & BA01005 & & & Canavieiras, BA, Brazil & $\mathrm{F}$ & CEPLAC & & $\mathrm{x}$ & $\mathrm{x}$ & $\mathrm{x}$ & $\mathrm{x}$ & $\mathrm{x}$ & \\
\hline & BA01007 & & & BA, Brazil & M & CEPLAC & & $\mathrm{x}$ & $\mathrm{x}$ & $\mathrm{x}$ & $\mathrm{x}$ & $\mathrm{x}$ & \\
\hline & BA01008 & & & BA, Brazil & $\mathrm{M}$ & CEPLAC & & & $\mathrm{x}$ & & & & \\
\hline & BA01009 & & & BA, Brazil & $\mathrm{M}$ & CEPLAC & & $\mathrm{x}$ & & $\mathrm{x}$ & & $\mathrm{x}$ & \\
\hline & BA01012 & & & BA, Brazil & & CEPLAC & & $\mathrm{x}$ & & & & & \\
\hline & LABEC 01008 & -14.82 & -39.03 & Ilheus, BA, Brazil & (F) & CEPLAC & & $\mathrm{x}$ & $\mathrm{x}$ & $\mathrm{x}$ & $\mathrm{x}$ & $\mathrm{x}$ & \\
\hline & LABEC 01009 & -14.82 & -39.03 & Ilheus, BA, Brazil & & CEPLAC & & $\mathrm{x}$ & $\mathrm{x}$ & $\mathrm{x}$ & $\mathrm{x}$ & $\mathrm{x}$ & \\
\hline & LABEC 01010 & -14.82 & -39.03 & Ilheus, BA, Brazil & & CEPLAC & & $\mathrm{x}$ & $\mathrm{x}$ & & $\mathrm{x}$ & $\mathrm{x}$ & \\
\hline & LABEC01011 & & & BA, Brazil & (F) & CEPLAC & & $\mathrm{x}$ & $\mathrm{x}$ & $\mathrm{x}$ & $\mathrm{x}$ & $\mathrm{x}$ & \\
\hline & LABEC01012 & & & BA, Brazil & & CEPLAC & & & & & & $\mathrm{x}$ & \\
\hline & LABEC 01013 & & & BA, Brazil & & CEPLAC & & $\mathrm{x}$ & $\mathrm{x}$ & & $\mathrm{x}$ & $\mathrm{x}$ & \\
\hline & LABEC 01015 & & & BA, Brazil & (F) & CEPLAC & & $\mathrm{x}$ & $\mathrm{x}$ & $\mathrm{x}$ & $\mathrm{x}$ & $\mathrm{x}$ & \\
\hline & LABEC01017 & & & BA, Brazil & & CEPLAC & & $\mathrm{x}$ & $\mathrm{x}$ & $\mathrm{x}$ & $\mathrm{x}$ & $\mathrm{x}$ & \\
\hline & & & & & & Total & & 12 & 12 & 9 & 10 & 14 & \\
\hline
\end{tabular}

MVZB - Museum of Vertebrate Zoology at Berkeley

LNN-UFPA - Laboratory of Neuroprotection and Experimental Neuroregeneration of the Federal University of Pará

CETAS: Wild Animals Screening Centers of Ceará (CE), Paraiba (PB), Pernambuco (PB), Alagoas (AL) and Bahia (BA)

UFPE - Federal University of Pernambuco

UFC - Federal University of Ceará

UFPB - Federal University of Paraiba

MHN UFAL - Museum of Natural History of the Federal University of Alagoas

CEPLAC - Zoobotanical Reserve

DEPAVE-SP - Technical Division of Veterinary Medicine and Wild Animals Management of São Paulo 
Table S2: $\tau$ a values for populations with signs of population expansion (and respective 95\% confidence intervals based in 1000 bootstrap replicates; Rogers, 1995 ; Excoffier et al. 2005). Pygmy sloth - Bradypus pygmaeus; maned sloth - B. torquatus; common sloth - B. variegatus. AFCS - central/southern Atlantic forest; AFNE - northeastern Atlantic forest.

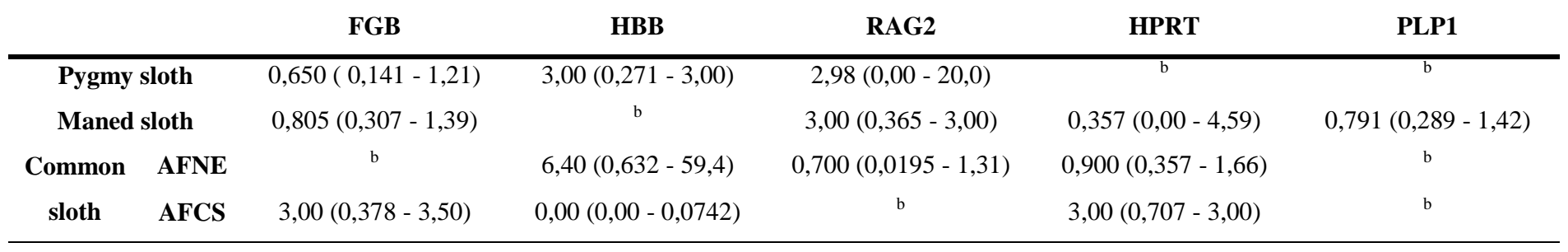

${ }^{\mathrm{a}} \tau=2 \mu \mathrm{t}, \mu$ - mutation rate per sequence size and per generation and $\mathrm{t}-$ time in generation years

${ }^{\mathrm{b}}$ Recombination events or lack of variation were observed for these genes. 


\section{CAPÍtulo 4.}

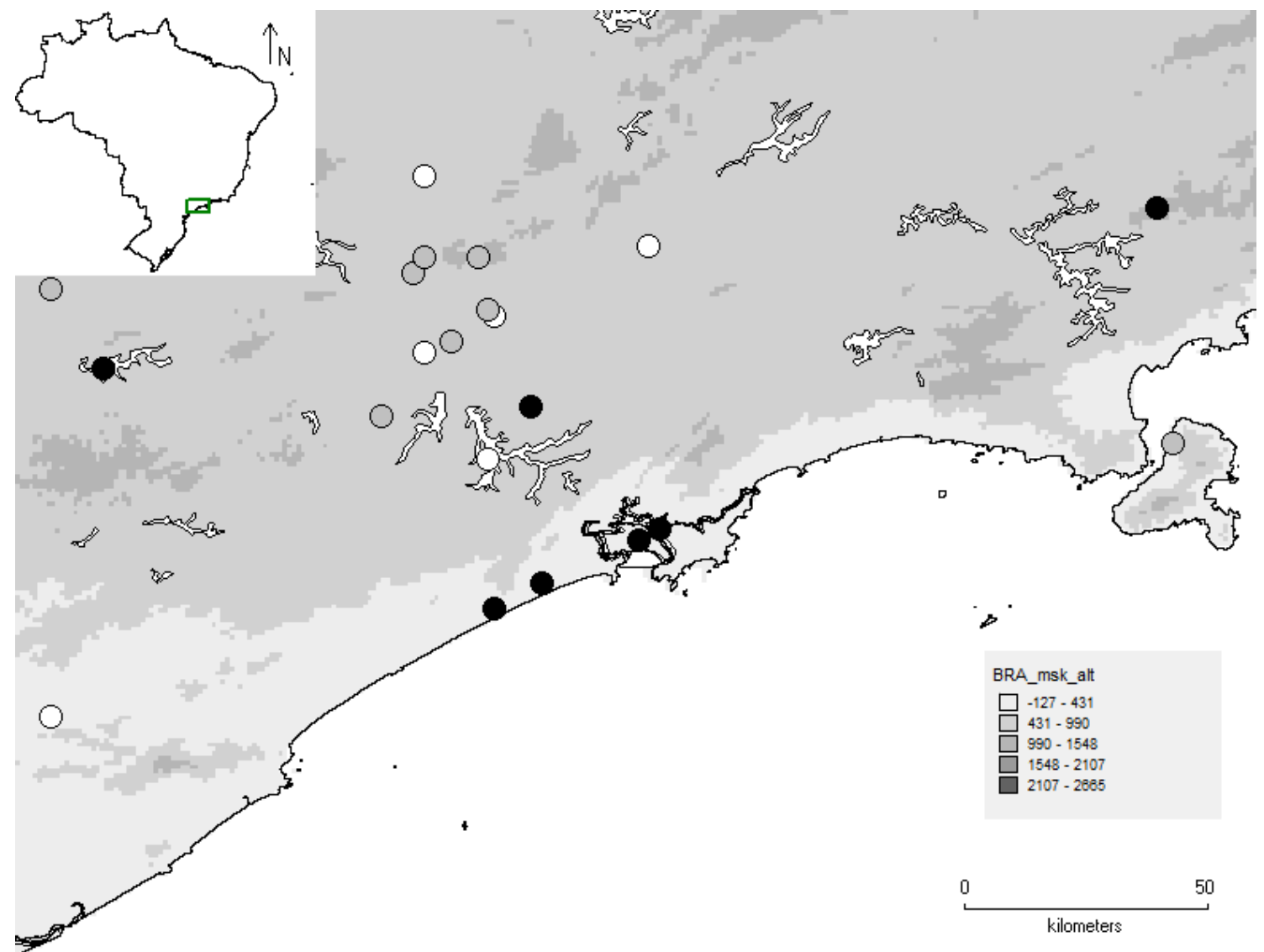

Figure S1 Geographic representation of the structure found within the geographic region 1 (GR1), relative to the distance to shore, the location of the Tietê river basin (white lines) and the altitude of the region. Black and white circles represent individuals allocated to each group, respectively, and the gray circles represent individuals with mixed ancestry. 


\section{Supplementary Material S2}

Bottleneck 1.2.02 Wilcoxon tests' results after 1000 replications.

\section{Northern population:}

T.P.M (variance among multiple steps: 12; proportion of single-step mutations: 95\%)

Probability (one tail for $\mathrm{H}$ deficiency): 0.81571

Probability (one tail for $\mathrm{H}$ excess): 0.18694

Probability (two tails for H excess or deficiency): 0.37389

T.P.M (variance among multiple steps: 30; proportion of single-step mutations: 70\%)

Probability (one tail for $\mathrm{H}$ deficiency): 0.99707

Probability (one tail for $\mathrm{H}$ excess): 0.00303

Probability (two tails for H excess or deficiency): 0.00606

\section{Central population:}

T.P.M (variance among multiple steps: 12; proportion of single-step mutations: 95\%)

Probability (one tail for $\mathrm{H}$ deficiency): 0.21053

Probability (one tail for $\mathrm{H}$ excess): 0.79281

Probability (two tails for H excess or deficiency): 0.42106

T.P.M (variance among multiple steps: 30; proportion of single-step mutations: 70\%)

Probability (one tail for $\mathrm{H}$ deficiency): 0.63341

Probability (one tail for $\mathrm{H}$ excess): 0.37095

Probability (two tails for H excess or deficiency): 0.74190

\section{Southern population:}

T.P.M (variance among multiple steps: 12; proportion of single-step mutations: 95\%)

Probability (one tail for $\mathrm{H}$ deficiency): 0.70400

Probability (one tail for $\mathrm{H}$ excess): 0.30141

Probability (two tails for $\mathrm{H}$ excess or deficiency): 0.60281

T.P.M (variance among multiple steps: 30; proportion of single-step mutations: 70\%)

Probability (one tail for $\mathrm{H}$ deficiency): 0.94425

Probability (one tail for $\mathrm{H}$ excess): 0.05758

Probability (two tails for H excess or deficiency): 0.11515 


\section{CAPÍTULO 5 .}

Supplementary Material S1. $P$-values obtained from the comparison of the mean expected heterozygosity $(H s)$ estimates for each determined subset against the respective $H s$ (same amount of loci) obtained from 3000 random subsamplings of loci, without replacement. Determined selection was base on $A$ (mean number of alleles); Ho (observed heterozygosity) and $\mathrm{He}$ (expected heterozygosity) within the total dataset (Overall), each population individually (Pop), and within the common sloth dataset (Taxa). More details in Material and Methods section. In brackets is the number of loci available within each population.

S2.1 Bradypus dataset. Bp - Bradypus pygmaeus; Bv - B. variegatus; Bv populations: PNM - Panama; MU - management unit; AMZEast - eastern Amazonia; AMZWest western Amazonia.

\begin{tabular}{|c|c|c|c|c|c|c|c|c|c|c|c|c|c|c|}
\hline & \multicolumn{7}{|c|}{ Overall (24) } & \multicolumn{7}{|c|}{ Pop } \\
\hline & MU1 & MU2 & MU3 & AMZEast & AMZWest & PNM & Bp & MU1 (35) & MU2 (38) & MU3 (43) & AMZEast (39) & AMZWest (43) & PNM (36) & Bp (24) \\
\hline 10 & 0,1360 & 0,2973 & 0,2563 & 0,0703 & 0,4767 & 0,0003 & 0,5170 & 0,0040 & 0,0010 & 0,0000 & 0,0003 & 0,0000 & 0,0000 & 0,0000 \\
\hline 20 & 0,1097 & 0,3370 & 0,1817 & 0,3650 & 0,1323 & 0,0693 & 0,5083 & 0,0553 & 0,0000 & 0,0000 & 0,0000 & 0,0000 & 0,0000 & 0,0133 \\
\hline 30 & & & & & & & & 0,2330 & 0,0003 & 0,0000 & 0,0000 & 0,0000 & 0,0000 & \\
\hline 40 & & & & & & & & & & 0,1073 & & 0,0003 & & \\
\hline \multicolumn{15}{|l|}{$\underset{Q}{H}$} \\
\hline $\boldsymbol{o}$ & \multicolumn{7}{|c|}{ Overall } & \multicolumn{7}{|c|}{ Pop } \\
\hline & MU1 & MU2 & MU3 & AMZEast & AMZWest & PNM & Bp & MU1 (35) & MU2 (38) & MU3 (43) & AMZEast (39) & AMZWest (43) & PNM (36) & Bp (24) \\
\hline 10 & 0,0010 & 0,0013 & 0,0050 & 0,0003 & 0,1010 & 0,1937 & 0,0030 & 0,0000 & 0,0000 & 0,0000 & 0,0003 & 0,0000 & 0,0087 & 0,0007 \\
\hline 20 & 0,0003 & 0,0000 & 0,0000 & 0,0420 & 0,0797 & 0,3180 & 0,4473 & 0,0000 & 0,0000 & 0,0000 & 0,0000 & 0,0000 & 0,0000 & 0,0000 \\
\hline 30 & & & & & & & & 0,0000 & 0,0000 & 0,0000 & 0,0000 & 0,0000 & 0,0000 & \\
\hline 40 & & & & & & & & & & 0,0127 & & 0,0073 & & \\
\hline \multicolumn{15}{|l|}{ He } \\
\hline & \multicolumn{7}{|c|}{ Overall (24) } & \multicolumn{7}{|c|}{ Pop } \\
\hline & MU1 & MU2 & MU3 & AMZEast & AMZWest & PNM & Bp & MU1 (35) & MU2 (38) & MU3 (43) & AMZEast (39) & AMZWest (43) & PNM (36) & Bp (24) \\
\hline 10 & 0,0147 & 0,0057 & 0,0023 & 0,0037 & 0,0110 & 0,0000 & 0,2830 & 0,0000 & 0,0000 & 0,0000 & 0,0000 & 0,0000 & 0,0000 & 0,0000 \\
\hline 20 & 0,0533 & 0,0017 & 0,0030 & 0,0373 & 0,4270 & 0,1583 & 0,2910 & 0,0000 & 0,0000 & 0,0000 & 0,0000 & 0,0000 & 0,0000 & 0,0000 \\
\hline 30 & & & & & & & & 0,0000 & 0,0000 & 0,0000 & 0,0000 & 0,0000 & 0,0000 & \\
\hline 40 & & & & & & & & & & 0,0100 & & 0,0003 & & \\
\hline
\end{tabular}


S2.1 (cont.) Bradypus dataset. Bp - Bradypus pygmaeus; Bv - B. variegatus; Bv populations: PNM - Panama; MU - management unit; AMZEast - eastern Amazonia; AMZWest - western Amazonia

\begin{tabular}{|c|c|c|c|c|c|c|}
\hline \multirow{2}{*}{$\boldsymbol{A}$} & \multicolumn{6}{|c|}{ Taxa (45) } \\
\hline & MU1 & MU2 & MU3 & AMZEast & AMZWest & PNM \\
\hline 10 & 0,1537 & 0,1970 & 0,0480 & 0,0080 & 0,1857 & 0,0063 \\
\hline 20 & 0,0127 & 0,0073 & 0,0000 & 0,0010 & 0,0073 & 0,0003 \\
\hline 30 & 0,1603 & 0,0637 & 0,0000 & 0,0040 & 0,0003 & 0,0000 \\
\hline 40 & 0,1773 & 0,0060 & 0,0003 & 0,0007 & 0,0007 & 0,0010 \\
\hline \multicolumn{7}{|l|}{$H$} \\
\hline & \multicolumn{6}{|c|}{ Taxa (45) } \\
\hline & MU1 & MU2 & MU3 & AMZEast & AMZWest & PNM \\
\hline 10 & 0,0000 & 0,0000 & 0,0007 & 0,0000 & 0,0483 & 0,0037 \\
\hline 20 & 0,0000 & 0,0000 & 0,0000 & 0,0003 & 0,0037 & 0,0003 \\
\hline 30 & 0,0000 & 0,0000 & 0,0000 & 0,0060 & 0,0013 & 0,0003 \\
\hline 40 & 0,0000 & 0,0000 & 0,0003 & 0,0327 & 0,0003 & 0,0250 \\
\hline \multicolumn{7}{|l|}{$\mathrm{He}$} \\
\hline & \multicolumn{6}{|c|}{ Taxa (45) } \\
\hline & MU1 & MU2 & MU3 & AMZEast & AMZWest & PNM \\
\hline 10 & 0,0000 & 0,0000 & 0,0000 & 0,0010 & 0,0007 & 0,0097 \\
\hline 20 & 0,0000 & 0,0000 & 0,0007 & 0,0127 & 0,0077 & 0,0003 \\
\hline 30 & 0,0000 & 0,0000 & 0,0000 & 0,0037 & 0,0033 & 0,0003 \\
\hline 40 & 0,0010 & 0,0003 & 0,0010 & 0,0060 & 0,0037 & 0,0343 \\
\hline
\end{tabular}

S2.2 Canis lupus dataset. Clf - Canis lupus familiaris; Cls - C. l. signatus.

$A$

\begin{tabular}{c|cc|cc} 
& \multicolumn{2}{|c|}{ Overall (43) } & \multicolumn{2}{c}{ Pop (43) } \\
\hline & Clf & Cls & Clf & Cls \\
$\mathbf{1 0}$ & 0,0000 & 0,1873 & 0,0000 & 0,0343 \\
$\mathbf{2 0}$ & 0,0000 & 0,1370 & 0,0000 & 0,0007 \\
$\mathbf{3 0}$ & 0,0017 & 0,0447 & 0,0013 & 0,0000 \\
$\mathbf{4 0}$ & 0,0243 & 0,0137 & 0,0097 & 0,0397
\end{tabular}

Ho

\begin{tabular}{c|cc|cc} 
& \multicolumn{2}{|c|}{ Overall (43) } & \multicolumn{2}{c}{ Pop (43) } \\
\hline & Clf & Cls & Clf & Cls \\
$\mathbf{1 0}$ & 0,0030 & 0,0000 & 0,0000 & 0,0000 \\
$\mathbf{2 0}$ & 0,0230 & 0,0000 & 0,0000 & 0,0000 \\
$\mathbf{3 0}$ & 0,0687 & 0,0000 & 0,0000 & 0,0000 \\
$\mathbf{4 0}$ & 0,6930 & 0,0000 & 0,0043 & 0,0000
\end{tabular}

$\mathrm{He}$

\begin{tabular}{l|cc|cc} 
He & \multicolumn{2}{|c|}{ Overall (43) } & \multicolumn{2}{c}{ Pop (43) } \\
\hline & Clf & Cls & Clf & Cls \\
$\mathbf{1 0}$ & 0,0013 & 0,0000 & 0,0000 & 0,0000 \\
$\mathbf{2 0}$ & 0,0000 & 0,0000 & 0,0000 & 0,0000 \\
$\mathbf{3 0}$ & 0,0630 & 0,0000 & 0,0000 & 0,0000 \\
$\mathbf{4 0}$ & 0,1620 & 0,0007 & 0,0000 & 0,0000
\end{tabular}


S2.3 Pan dataset. Bonobo (Pp - Pan paniscus); Chimpanzee populations (P. troglodytes: C - Central; E - Eastern; W - Western).

\begin{tabular}{|c|c|c|c|c|c|c|c|c|}
\hline \multirow[t]{2}{*}{$\boldsymbol{A}$} & \multicolumn{4}{|c|}{ Overall (291) } & \multicolumn{4}{|c|}{ Pop } \\
\hline & $\mathrm{C}$ & $\mathbf{E}$ & $\mathbf{W}$ & $\mathbf{P p}$ & C (283) & E (273) & W (277) & Pp (261) \\
\hline 10 & 0,0000 & 0,0000 & 0,0030 & 0,0000 & 0,0000 & 0,0000 & 0,0000 & 0,0000 \\
\hline 20 & 0,0000 & 0,0000 & 0,0000 & 0,0007 & 0,0000 & 0,0000 & 0,0000 & 0,0000 \\
\hline 30 & 0,0000 & 0,0000 & 0,0000 & 0,0000 & 0,0000 & 0,0000 & 0,0000 & 0,0000 \\
\hline 40 & 0,0000 & 0,0000 & 0,0000 & 0,0003 & 0,0000 & 0,0000 & 0,0000 & 0,0000 \\
\hline 50 & 0,0000 & 0,0000 & 0,0000 & 0,0000 & 0,0000 & 0,0000 & 0,0000 & 0,0000 \\
\hline 100 & 0,0000 & 0,0000 & 0,0000 & 0,0000 & 0,0000 & 0,0000 & 0,0000 & 0,0000 \\
\hline 150 & 0,0000 & 0,0000 & 0,0000 & 0,0000 & 0,0000 & 0,0000 & 0,0000 & 0,0000 \\
\hline 200 & 0,0000 & 0,0000 & 0,0000 & 0,0000 & 0,0000 & 0,0000 & 0,0000 & 0,0000 \\
\hline 250 & 0,0000 & 0,0000 & 0,0000 & 0,0000 & 0,0000 & 0,0000 & 0,0000 & 0,0000 \\
\hline \multirow[t]{2}{*}{$\mathrm{Ho}$} & \multicolumn{4}{|c|}{ Overall (291) } & \multicolumn{4}{|c|}{ Pop } \\
\hline & $\mathrm{C}$ & $\mathbf{E}$ & $\mathbf{W}$ & $\mathbf{P p}$ & C (283) & E (273) & W (277) & Pp (261) \\
\hline 10 & 0,0023 & 0,0007 & 0,0000 & 0,0123 & 0,0283 & 0,0407 & 0,0000 & 0,0010 \\
\hline 20 & 0,0000 & 0,0000 & 0,0000 & 0,0000 & 0,0000 & 0,0000 & 0,0000 & 0,0000 \\
\hline 30 & 0,0000 & 0,0000 & 0,0000 & 0,0000 & 0,0000 & 0,0000 & 0,0000 & 0,0000 \\
\hline 40 & 0,0000 & 0,0000 & 0,0000 & 0,0000 & 0,0000 & 0,0000 & 0,0000 & 0,0000 \\
\hline 50 & 0,0000 & 0,0000 & 0,0000 & 0,0000 & 0,0000 & 0,0000 & 0,0000 & 0,0000 \\
\hline 100 & 0,0000 & 0,0000 & 0,0000 & 0,0000 & 0,0000 & 0,0000 & 0,0000 & 0,0000 \\
\hline 150 & 0,0000 & 0,0000 & 0,0000 & 0,0000 & 0,0000 & 0,0000 & 0,0000 & 0,0000 \\
\hline 200 & 0,0000 & 0,0000 & 0,0000 & 0,0000 & 0,0000 & 0,0000 & 0,0000 & 0,0000 \\
\hline 250 & 0,0000 & 0,0000 & 0,0000 & 0,0000 & 0,0000 & 0,0000 & 0,0000 & 0,0000 \\
\hline \multirow[t]{2}{*}{$\mathrm{He}$} & \multicolumn{4}{|c|}{ Overall (291) } & \multicolumn{4}{|c|}{ Pop } \\
\hline & $\mathrm{C}$ & $\mathbf{E}$ & W & $\mathbf{P p}$ & C (283) & E (273) & W (277) & Pp (261) \\
\hline 10 & 0,0000 & 0,0000 & 0,0000 & 0,4580 & 0,0000 & 0,0000 & 0,0000 & 0,0000 \\
\hline 20 & 0,0000 & 0,0000 & 0,0000 & 0,0603 & 0,0000 & 0,0000 & 0,0000 & 0,0000 \\
\hline 30 & 0,0000 & 0,0000 & 0,0000 & 0,0577 & 0,0000 & 0,0000 & 0,0000 & 0,0000 \\
\hline 40 & 0,0000 & 0,0000 & 0,0000 & 0,0103 & 0,0000 & 0,0000 & 0,0000 & 0,0000 \\
\hline 50 & 0,0000 & 0,0000 & 0,0000 & 0,0007 & 0,0000 & 0,0000 & 0,0000 & 0,0000 \\
\hline 100 & 0,0000 & 0,0000 & 0,0000 & 0,0000 & 0,0000 & 0,0000 & 0,0000 & 0,0000 \\
\hline 150 & 0,0000 & 0,0000 & 0,0000 & 0,0000 & 0,0000 & 0,0000 & 0,0000 & 0,0000 \\
\hline 200 & 0,0000 & 0,0000 & 0,0000 & 0,0000 & 0,0000 & 0,0000 & 0,0000 & 0,0000 \\
\hline 250 & 0,0000 & 0,0000 & 0,0000 & 0,0000 & 0,0000 & 0,0000 & 0,0000 & 0,0000 \\
\hline
\end{tabular}




\section{CAPÍTULO 6.}

Appendix I: Records taken during the field-works reported both in PARNASO (Serra dos Órgãos National Park) and BGBM (Botanical Garden Benjamin Maranhão).

\begin{tabular}{|c|c|c|c|c|c|c|}
\hline Date & Time* & Sex $* *$ & $\begin{array}{l}\text { Behavioural } \\
\text { category }\end{array}$ & Postural / Locomotor category & Other & Location \\
\hline $14-8-10$ & $14: 24$ & Female (IX) & Resting & Huddle sitting-total & Cecropia sp. & PARNASO \\
\hline $15-8-10$ & 13:03 & Female (IX) & Feeding & & Cecropia sp. & PARNASO \\
\hline $15-8-10$ & $14: 56$ & Male (VII) & Feeding & & Cecropia sp. & PARNASO \\
\hline $16-8-10$ & $10: 23$ & Male (VII) & Moving & Horizontal-moving & $\begin{array}{l}\text { First in Cecropia sp. (moved } \\
\text { at least } 50 \mathrm{~m} \text { ) }\end{array}$ & PARNASO \\
\hline $16-8-10$ & 12:01 & Female (IX) & Moving & Climbing & Cecropia sp. & PARNASO \\
\hline $17-8-10$ & 9:46 & Undetermined & Resting & Huddle hanging-total & & PARNASO \\
\hline $17-8-10$ & $12: 14$ & Male (VII) & Moving & Horizontal-moving and Climbing & & PARNASO \\
\hline $17-8-10$ & $14: 20$ & Undetermined & Feeding & & Cecropia sp. & PARNASO \\
\hline $18-8-10$ & 9:19 & $\begin{array}{l}\text { Female (IX) and } \\
\text { Male (II) }\end{array}$ & Feeding & & Cecropia sp. & PARNASO \\
\hline $18-8-10$ & 9:58 & Male (VII) & Moving & Climbing and Horizontal-moving & & PARNASO \\
\hline $18-8-10$ & $14: 36$ & Female (IX) & Resting & Huddle sitting-total & Cecropia sp. & PARNASO \\
\hline $18-8-10$ & $14: 36$ & Male (II) & $\begin{array}{l}\text { Resting / Self- } \\
\text { grooming }\end{array}$ & Huddle sitting-total / Huddle sitting-partial / Extended hanging & Cecropia sp. & PARNASO \\
\hline $18-8-10$ & $15: 19$ & Female (IX) & Resting & Huddle sitting-partial & Cecropia sp. & PARNASO \\
\hline $18-8-10$ & $16: 36$ & $\begin{array}{l}\text { Female with an } \\
\text { offspring (VIII) }\end{array}$ & Resting & Huddle sitting-total (offspring not visible) & Cecropia sp. & PARNASO \\
\hline $19-8-10$ & 9:20 & Male (IX) & Feeding & & Cecropia sp. & PARNASO \\
\hline $19-8-10$ & $9: 30$ & Female (IX) & Feeding & Extended hanging upside down & Cecropia sp. & PARNASO \\
\hline $19-8-10$ & $9: 30$ & Male (II) & Moving & Climbing & Cecropia sp. & PARNASO \\
\hline $19-8-10$ & 11:00 & $\begin{array}{l}\text { Female with an } \\
\text { offspring (VIII) }\end{array}$ & Resting & Huddle sitting-partial (offspring grabbed the female's ventral region) & Cecropia sp. & PARNASO \\
\hline $19-8-10$ & $15: 59$ & Male (IX) & Feeding & & Cecropia sp. & PARNASO \\
\hline $19-7-11$ & $8: 33$ & Undetermined & Resting & Huddle sitting-total & Cecropia sp. & BGBM \\
\hline $19-7-11$ & $8: 39$ & Female (III) & Resting & Huddle sitting-total & Cecropia sp. & BGBM \\
\hline $19-7-11$ & $8: 41$ & Male & Moving & Horizontal-moving & & BGBM \\
\hline $19-7-11$ & $8: 43$ & Undetermined & Resting & Huddle sitting-total & & BGBM \\
\hline $19-7-11$ & $8: 50$ & Male (IV) & Moving/Resting & Climbing / Huddle sitting-total & Cecropia sp. & BGBM \\
\hline $19-7-11$ & $9: 22$ & Undetermined & Resting & Huddle hanging-total & Cecropia sp. & BGBM \\
\hline $19-7-11$ & $9: 28$ & Undetermined & Moving & Climbing & & BGBM \\
\hline $19-7-11$ & 9:36 & Undetermined & Resting & Huddle sitting-total & & BGBM \\
\hline $20-7-11$ & $8: 30$ & Male & Resting & Huddle sitting-partial / Extended sitting & & BGBM \\
\hline $20-7-11$ & $8: 30$ & Undetermined & Resting & Huddle sitting-total & Cecropia sp. & BGBM \\
\hline $20-7-11$ & $8: 32$ & $\begin{array}{l}\text { Two males ( } \mathrm{V} \text { and } \\
\text { VI) }\end{array}$ & Moving & Horizontal-moving & & BGBM \\
\hline $20-7-11$ & $8: 43$ & Female & Moving & Climbing / Extended hanging & & BGBM \\
\hline
\end{tabular}




\begin{tabular}{|c|c|c|c|c|c|c|}
\hline Date & Time* & Sex $* *$ & $\begin{array}{c}\text { Behavioural } \\
\text { category }\end{array}$ & Postural / Locomotor category & Other & Location \\
\hline $20-7-11$ & $8: 43$ & Female & Moving & Climbing & & BGBM \\
\hline $20-7-11$ & $8: 44$ & Juvenile & Moving & Horizontal-moving & & BGBM \\
\hline $20-7-11$ & $8: 46$ & Undetermined & Moving & Climbing / Extended hanging & & BGBM \\
\hline $20-7-11$ & $8: 47$ & Undetermined & Moving & Climbing & & BGBM \\
\hline $20-7-11$ & $8: 59$ & Undetermined & Moving & Horizontal moving & & BGBM \\
\hline $20-7-11$ & $9: 30$ & Undetermined & Moving & Climbing & & BGBM \\
\hline $20-7-11$ & $9: 39$ & $\begin{array}{l}\text { Female with an } \\
\text { offspring }\end{array}$ & Moving & Horizontal-moving (offspring grabbed the female's ventre) & & BGBM \\
\hline $20-7-11$ & $9: 43$ & Female & Moving & Climbing & & BGBM \\
\hline $20-7-11$ & 10:06 & Male & Moving & Horizontal moving / Huddle hanging-total & & BGBM \\
\hline $20-7-11$ & $10: 23$ & Undetermined & Resting & Huddle sitting-partial & & BGBM \\
\hline $20-7-11$ & $10: 32$ & Undetermined & Moving & Climbing & & BGBM \\
\hline $20-7-11$ & $10: 43$ & $\begin{array}{l}\text { Female with an } \\
\text { offspring }\end{array}$ & Resting/Feeding & $\begin{array}{l}\text { Female huddle sitting-partial (offspring grabbed both female's ventre and the food } \\
\text { item) }\end{array}$ & Cecropia sp. & BGBM \\
\hline $20-7-11$ & 14:45 & Undetermined & Resting & Extended lying $^{2}$ & & BGBM \\
\hline $20-7-11$ & $14: 52$ & Undetermined & Moving & Climbing & & BGBM \\
\hline $20-7-11$ & 15:07 & Undetermined & Moving & Horizontal-moving & & BGBM \\
\hline 21-7-11 & 8:00 & Undetermined & Resting & Huddle sitting-total & & BGBM \\
\hline 21-7-11 & $8: 06$ & Female & Resting & Huddle sitting-partial (sharing tree with the previous male) & Cecropia sp. & BGBM \\
\hline $21-7-11$ & $8: 06$ & Male & Moving & Horizontal-moving & Cecropia sp. & BGBM \\
\hline $21-7-11$ & $8: 27$ & Male & Resting & Huddle sitting-partial & & BGBM \\
\hline $21-7-11$ & $8: 30$ & Juvenil & Moving & Horizontal-moving & & BGBM \\
\hline $21-7-11$ & $8: 47$ & Undetermined & $\begin{array}{l}\text { Moving/Self- } \\
\text { grooming }\end{array}$ & Horizontal-moving / Extended hanging & Cecropia sp. & BGBM \\
\hline $21-7-11$ & $8: 47$ & Female & $\begin{array}{l}\text { Resting/Self- } \\
\text { grooming }\end{array}$ & Extended hanging upside down & Cecropia sp. & BGBM \\
\hline $21-7-11$ & $8: 47$ & Undetermined & Resting & Huddle sitting-total & & BGBM \\
\hline $21-7-11$ & $8: 47$ & Undetermined & Resting & Huddle sitting-total & & BGBM \\
\hline $21-7-11$ & $8: 59$ & Undetermined & Feeding & Extended hanging upside down & & BGBM \\
\hline $21-7-11$ & $9: 23$ & Undetermined & Resting & Extended hanging & & BGBM \\
\hline $21-7-11$ & 10:09 & Juvenile male & Moving & Horizontal-moving & & BGBM \\
\hline $21-7-11$ & $10: 15$ & Male & Feeding / Resting & Huddle sitting-partial & Cecropia sp. & BGBM \\
\hline $21-7-11$ & $10: 15$ & Female & Moving & Horizontal moving & & BGBM \\
\hline $21-7-11$ & $10: 15$ & Male & Moving & Climbing & & BGBM \\
\hline $21-7-11$ & $10: 15$ & Male & Feeding & & Cecropia sp. & BGBM \\
\hline $21-7-11$ & $10: 34$ & Undetermined & Moving & Climbing & Bamboo & BGBM \\
\hline $21-7-11$ & 10:34 & Male & Resting & Huddle sitting-total & Cecropia sp. & BGBM \\
\hline $22-7-11$ & $8: 20$ & Female & Moving & Climbing & Cecropia sp. & BGBM \\
\hline $22-7-11$ & $8: 20$ & Undetermined & Moving & Climbing & & BGBM \\
\hline $22-7-11$ & $8: 21$ & Male & Moving & Climbing & & BGBM \\
\hline $22-7-11$ & $8: 37$ & Female & Moving & Climbing & Bamboo & BGBM \\
\hline $22-7-11$ & $8: 44$ & Female & Resting & Huddle sitting-total & $\begin{array}{l}\text { High in spite of the wind. } \\
\text { Cecropia sp. }\end{array}$ & BGBM \\
\hline
\end{tabular}




\begin{tabular}{|c|c|c|c|c|c|c|}
\hline Date & Time* & Sex ** & $\begin{array}{c}\text { Behavioural } \\
\text { category }\end{array}$ & Postural / Locomotor category & Other & Location \\
\hline $22-7-11$ & $8: 51$ & Female & Moving & Horizontal-moving & Cecropia $s p$. & BGBM \\
\hline $22-7-11$ & $8: 52$ & Female & Moving & Horizontal-moving & Cecropia sp. & BGBM \\
\hline $22-7-11$ & $8: 52$ & Undetermined & Resting & Huddle sitting-total & Cecropia sp. & BGBM \\
\hline $22-7-11$ & $8: 52$ & Female & Moving & Horizontal-moving & Cecropia sp. & BGBM \\
\hline $22-7-11$ & $9: 10$ & Male & Defecating $^{1}$ & Climbing & & BGBM \\
\hline $22-7-11$ & $9: 10$ & Undetermined & Moving & Horizontal-moving & Bamboo & BGBM \\
\hline $22-7-11$ & $9: 28$ & Male & Moving & Climbing & & BGBM \\
\hline $22-7-11$ & $9: 28$ & Male & Moving & Climbing & & BGBM \\
\hline $22-7-11$ & $9: 28$ & Juvenile Male & Moving & Horizontal-moving & & BGBM \\
\hline $22-7-11$ & $9: 28$ & Female & Moving & Horizontal-moving & & BGBM \\
\hline $22-7-11$ & 10:05 & Female & Moving & Horizontal-moving & Cecropia sp. & BGBM \\
\hline $22-7-11$ & 10:05 & Undetermined & Resting & Extended sitting & & BGBM \\
\hline $22-7-11$ & $10: 33$ & Undetermined & Moving & Climbing & Bamboo & BGBM \\
\hline $22-7-11$ & $11: 10$ & Undetermined & Resting & Huddle sitting-total & High in spite of the wind. & BGBM \\
\hline $22-7-11$ & $11: 46$ & $\begin{array}{l}\text { Female with an } \\
\text { offspring }\end{array}$ & Resting & Vertically extended ${ }^{3}$ & & BGBM \\
\hline $22-7-11$ & 14:07 & Male & Feeding & & Bindweed & BGBM \\
\hline $22-7-11$ & 14:41 & Undetermined & Moving & Horizontal-moving & & BGBM \\
\hline $22-7-11$ & $14: 46$ & Undetermined & Moving & Climbing & & BGBM \\
\hline $22-7-11$ & 15:16 & Male & Moving & Climbing & & BGBM \\
\hline $22-7-11$ & $15: 55$ & Female & Moving & Climbing & & BGBM \\
\hline
\end{tabular}

*Time of the first record

** In brackets are the codes given for some animals that could be identified as being the same individual across the text.

${ }^{1}$ Behavioural category not considered by Urbani \& Bosque (2006). Staying stationary in the base of the tree trunk touching the ground.

${ }^{2}$ Postural category not described by Urbani \& Bosque (2006). Stationary; supported by all limbs, ventral surfaces against the tree trunk

${ }^{3}$ Postural category not described by Urbani \& Bosque (2006). Stationary; supported by all limbs, ventral surfaces against the tree trunk in a vertical position. In this particular casa the offspring

was positioned between the ventral region and the tree trunk 
CAPÍtULO 2.

Fig. 1 a cores (pág. 18/19)
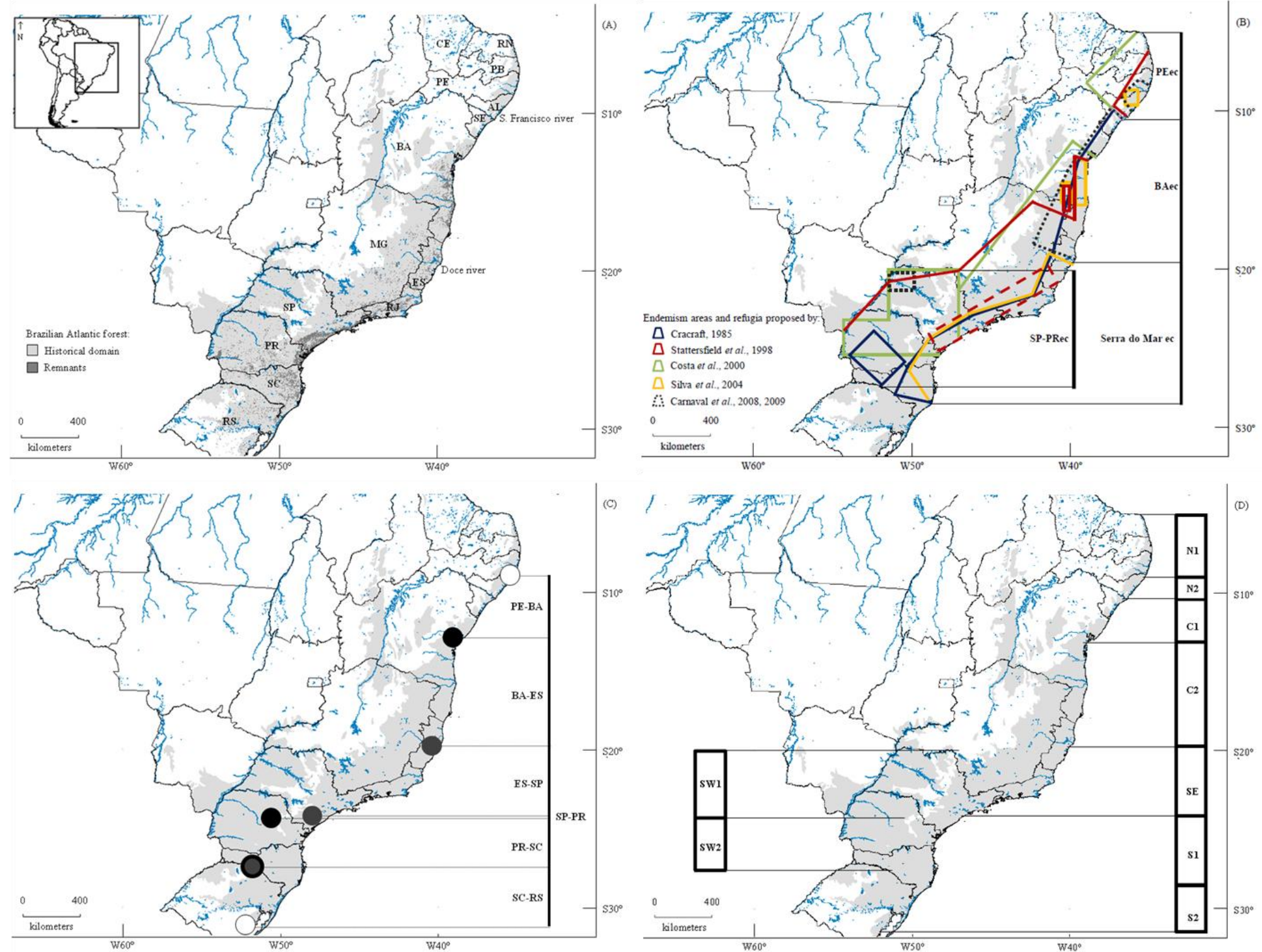